

\section{DISCLAIMER}

This report was prepared as an account of work sponsored by an agency of the United States Government. Neither the United States Government nor any agency Thereof, nor any of their employees, makes any warranty, express or implied, or assumes any legal liability or responsibility for the accuracy, completeness, or usefulness of any information, apparatus, product, or process disclosed, or represents that its use would not infringe privately owned rights. Reference herein to any specific commercial product, process, or service by trade name, trademark, manufacturer, or otherwise does not necessarily constitute or imply its endorsement, recommendation, or favoring by the United States Government or any agency thereof. The views and opinions of authors expressed herein do not necessarily state or reflect those of the United States Government or any agency thereof. 


\section{DISCLAIMER}

Portions of this document may be illegible in electronic image products. Images are produced from the best available original document. 
Printed in the United States of America

Available from

National Technical Information Service

U.S. Department of Commerce

5285 Port Royal Road

Springfield, Virginia 22161

Price: Printed Copy $\$ 9.00$; Microfiche $\$ 3.00$

NOTICE

Reference to a company or product name does not imply approval or recommendation of the product by the Oregon Institute of Technology or the Oregon Department of Economic Development or by the U.S. Department of Energy to the exclusion of others that may be suitable.

This report was prepared as an account of work sponsored by the United States Government. Neither the United States nor the Department of Energy, nor any of their employees, nor any of their contractors, subcontractors, or their employees, makes any warranty, express or implied, or assumes any legal liability or responsibility for the accuracy, completeness or usefulness of any information, apparatus, product or process disclosed, or represents that its use would not infringe privately owned rights. 
ID0/1621-1

Distribution Category:

$\mathrm{UC}-66 \mathrm{~g}$

\section{AGRIBUSINESS GEOTHERMAL ENERGY UTILIZATION POTENTIAL \\ OF KLAMATH AND WESTERN SNAKE RIVER BASINS, OREGON}

Final Report

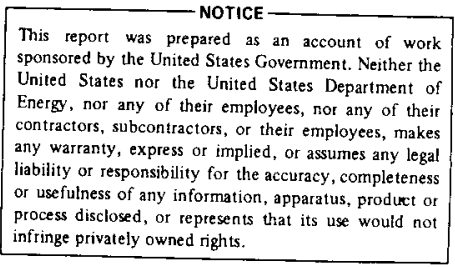

Paul J. Lienau, Principal Investigator

Richard Bowen James E. Curtis John N. Groupe
Charles Higbee

Donald A. Hull

Don Karr
Saul Laskin

John W. Lund

Norman Peterson

March 1978

Prepared for the

U.S. Department of Energy

Division of Geothermal Energy

Under Contract No. EY-76-S-07-1621

$$
0851
$$
Oregon Institute of Technology Klamath Falls, Oregon 97601

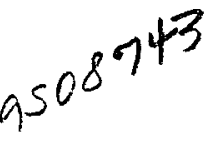
Deptogy \& Mineral Industries Portland, Oregon 9508744
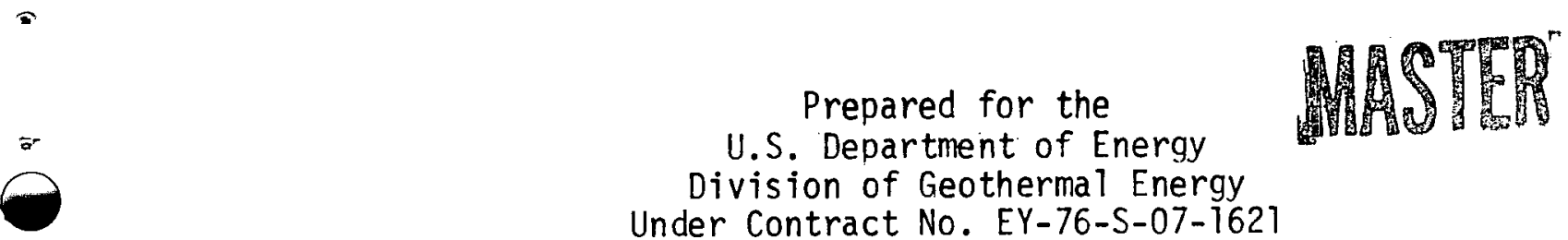


\section{ABSTRACT}

Resource assessment and methods of direct utilization for existing and prospective food processing plants have been determined in two geothermal resource areas in Oregon. Ore-Ida Foods, Inc. and Amalgamated Sugar Company in the Snake River Basin; Western Polymer Corporation (potato starch extraction) and three prospective industries--vegetable dehydration, alfalfa drying and greenhouses--in the $\mathrm{Kl}$ amath Basin have been analyzed for direct utilization of geothermal fluids. Existing geologic knowledge has been integrated to indicate locations, depth, quality, and estimated productivity of the geothermal reservoirs. Energy-economic needs and balances, along with cost and energy savings associated with field development, delivery systems, in-plant applications and fluid disposal have been calculated for interested industrial representatives. 
The policy of U.S. DOE is to encourage use of the metric system, formally called the International System of Units (SI). This report uses metric units for resource assessment and engineering units for the engineering and economic section. The following table shows conversion factors used.

\begin{tabular}{|c|c|c|c|}
\hline Quantity & convert from & To & Multiply by \\
\hline \multirow[t]{3}{*}{ Length } & $\mathrm{cm}$ & inches & $3.937 \times 10^{-1}$ \\
\hline & $\mathrm{m}$ & feet & 3.281 \\
\hline & $\mathrm{km}$ & mile & $6.215 \times 10^{-1}$ \\
\hline \multirow[t]{2}{*}{ Area } & $m^{2}$ & $f t^{2}$ & $1.076 \times 10^{1}$ \\
\hline & $\mathrm{m}^{2}$ & acre & $2.471 \times 10^{-4}$ \\
\hline Volume & $m^{3}$ & $f t^{3}$ & $3.531 \times 10^{1}$ \\
\hline Temperature & ${ }^{\circ} \mathrm{C}$ & ${ }^{\circ} \mathrm{F}$ & $t f=1.8 t c+32$ \\
\hline Temperature difference & $\Delta T K$ & $\Delta T f$ & 1.8 \\
\hline Mass & $\mathrm{kg}$ & pound & 2.205 \\
\hline \multirow[t]{2}{*}{ Pressure } & $\mathrm{kN} / \mathrm{m}^{2}$ & psi & $1.450 \times 10^{-1}$ \\
\hline & $\mathrm{kN} / \mathrm{m}^{2}$ & $\begin{array}{l}\text { inches } \\
\text { of } \mathrm{Hg}\end{array}$ & $2.953 \times 10^{-1}$ \\
\hline \multirow[t]{4}{*}{ Energy } & $\mathrm{k}$ cal & Btu & 3.968 \\
\hline & J & Btu & $9.479 \times 10^{-4}$ \\
\hline & J & kWh & $2.778 \times 10^{-7}$ \\
\hline & $\mathrm{J}$ & $f t-1 b$ & $7.375 \times 10^{-1}$ \\
\hline Power & $W$ & $\mathrm{Btu} / \mathrm{h}$ & 3.412 \\
\hline \multirow[t]{3}{*}{ Flow } & $\mathrm{kg} / \mathrm{sec}$ & $1 b / h$ & $7.920 \times 10^{3}$ \\
\hline & $\mathrm{m}^{3} / \mathrm{s}$ & gpm & $1.585 \times 10^{4}$ \\
\hline & $\mathrm{m}^{3} / \mathrm{s}$ & $\mathrm{cfm}$ & $2.119 \times 10^{3}$ \\
\hline \multirow[t]{2}{*}{ Enthalpy } & $\mathrm{kcal} / \mathrm{kg}$ & Btu/1b & $1.143 \times 10^{-1}$ \\
\hline & $\mathrm{J} / \mathrm{kg}$ & Btu/1b & $4.299 \times 10^{-4}$ \\
\hline
\end{tabular}


ABSTRACT ........................... $i$. .

CONVERSION TABLE .............................

I. INTRODUCTION ....................... . . 1

A. General ................. 1

B. Objective ................. 1

II. SUMMARY AND CONCLUSIONS . . . . . . . . . . . . 2

III. RESOURCE ASSESSMENT . . . . . . . . . . . . . . . 9

A. Introduction ................. . . . 9

B. Klamath Basin Assessment ............ 10

1. Introduction .............. 10

a. Previous Work ........... . 10

b. Geology ............. 11

c. Geothermai Potential ......... 12

2. Subarea Assessment ............... 14

a. Klamath Falls/North Altamont/Pelican City . . 14

b. South Altamont/Miller Hill ........ 16

c. Klamath Hills/Spring Lake Valley . . . . . . 16

d. Olene Gap/Poe Valley. . . . . . . . . . . . 19

e. Merrill/Malin .............. 19

f. Keno/Klamath River............... 21

g. Langell Valley. . . . . . . . . . . . 21

h. Sprague River .............. 25

C. Western Snake River Basin Assessment . . . . . . . 25

1. Introduction . . . . . . . . . . . . . . . 25

a. Previous Work . . . . . . . . . . . . . 27

b. Geology .............. . . 27

c. Geothermal Potential ......... 30

2. Subarea Assessment . . . . . . . . . . . . . 32

a. Ontario ................ . . 32

b. Nyssa . . . . . . . . . . . . . . . . . . 35

c. Adrian................ . . . 37

d. Vale.................. . . . 39

e. Bully creek . . . . . . . . . . . . . . 42

D. Reservoir Management . . . . . . . . . . . . . . 45

E. Drilling and Transmission Costs .......... 47

1. Western Snake River Basin .......... 48

2. Klamath Basin ............... . . 49

3. Transmission Costs ........... 57 
F. Institutional Factors ............ . 53

1. Environmental. ............ . . 53

a. Drilling............... 53

b. Disposal of Excess Water ......... 53

c. Other Factors ............ . . 55

2. Regulatory ............... 56

a. Federal ............. 56

b. State ............. 57

c. County................. 58

IV. ENGINEERING AND ECONOMIC ANALYSIS .......... 59

A. Introduction . . . . . . . . . . . . . . . . 59

B. Klamath Basin ............... 62

1. Background and Selection Criteria ...... 62

2. Onion Dehydration ............ 66

3. Alfalfa Dehydration . . . . . . . . . . . 84

4. Western Polymer Corporation .......... 98

5. Greenhouses .............. . 111

C. Snake River Basin . . . . . . . . . . . 124

1. Background . . . . . . . . . . . . . . . . 124

2. Ama l gamated Sugar Company ......... 125

3. Ore-Ida Foods, Inc. . . . . . . . . . . 146

v. REFERENCES ..................... 161

VI. APPENDICES ............... 166

A. Comparative costs of Conventional Energy Suppi ies : : 167

B. Annual Equivalent Cost Formula . . . . . . . . . . 170

C. Potential for Greenhouse Development in the Klamath 175

D. Organizations contacted .................. 179 
Page

I. U.S. Public Health Service Drinking Water Standards, 1962 .................... . . 55

II. Klamath and Western Snake River Basin Farm Products . . 59

III. Onion Dehydration ............... . 72

IV. Onion Dehydration Plant.............. 81

V. Alfalfa Pelletizing Plant............. 93

VI. Break-Even in Tons of Product Versus Project Life . . . 95

VII. Western Polymer Corporation Fuel Costs . . . . . . . 103

VIII. Western Polymer Corporation Option I - 200\% Fell . . . 104

IX. Option I. Ten-Year Cash Flow Using a 150 Percent Declining Balance Depreciation and 9 Percent Cost Capital...................... 105

X. Option I. Ten-Year Cash Flow Using a 200 Percent Declining Balance Depreciation and 9 Percent Cost Capital................... 106

XI. Western Polymer Corporation Option II - 72 ${ }^{\circ} \mathrm{F}$ Weli . . 107

XII. Option II. Ten-Year Cash Flow Using a 200 Percent Declining Balance Depreciation and 9 Percent Cost Capital............................. 108

XIII. Option III - Drilling Existing Well Deeper . . . . . . 109

XIV. Option III. Ten-Year Cash Flow Using a 200 Percent Declining Balance Depreciation and 9 Percent Cost Capital..................... 110

XV. Investment Costs for a 15-Acre Greenhouse Comples . . 118

XVI. Greenhouse Conversion Costs for Geothermal Energy . . . 118

XVII. Greenhouse Annual Operating and Maintenance Costs . . . 119

XVIII. Twenty-Year Projection of Annual Energy Costs for a 15-Acre Greenhouse Complex .......... . 120

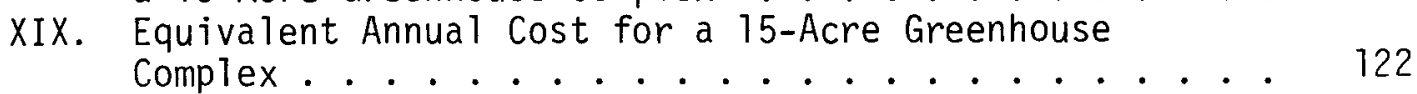

$X X$. Additional Capital Investment Required for a 123

XXI. Steam Balance . . . . . . . . . . . . . . . . . . . . . . . . 134

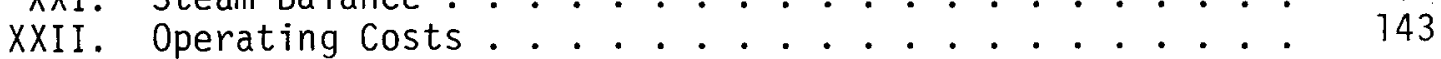

XXIII. Amalgamated Sugar Company Conversion Costs for 144

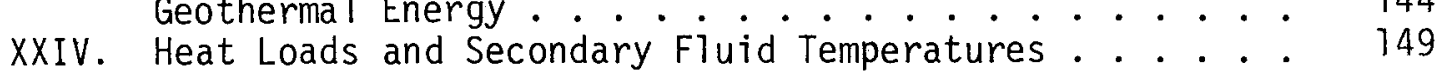

$X X V$. Ore Ida Foods, Inc. Annual Savings Recap for Geothermal Conversion .. . . . . . . . . . . . 157

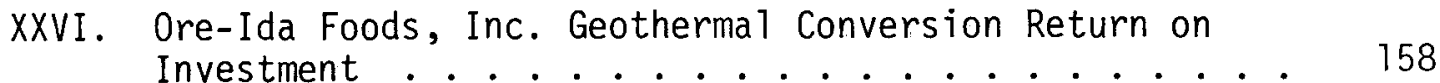

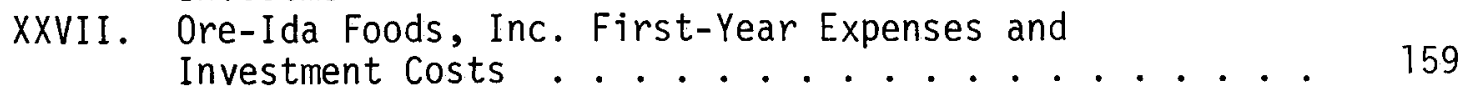

XXVIII. Ore-Ida Foods, Inc. Tangible Asset Depreciation . . . 160 


\section{LIST OF FIGURES}

Figure Number $\quad \underline{\text { Page }}$

1. Subarea Index, Klamath County ........... 13

2. Klamath Falis/North Altamont/Pelican City Subarea . . . . 15

3. South Altamont/Miller Hill Subarea . . . . . . . . . 17

4. Klamath Hills/Spring Lake Valley . . . . . . . . . . . 18

5. Olene Gap/Poe Valley Subarea . . . . . . . . . . . . . . . 20

6. Merrill/Mal in Subarea ................ 22

7. Keno/Klamath River Subarea .............. 23

8. Langell Valley Subarea ................. 24

9. Sprague River Valley Subarea . . . . . . . . . . . . . 26

10. Western Snake River Basin (Positive) . . . . . . . . 28

11. Cross-Section ................ . . 29

12. Temperature Gradients, Western Snake ........... 31

13. Subarea Index Map, Western Snake ........... 33

14. Ontario--Marginal Data ............ . 34

15. Nyssa Subarea--Marginal Data ............ 36

16. Adrian Subarea--Marginal Data ........... 38

17. Vale--Marginal Data ............... 40

18. Bul1y Creek--Marginal Data ............ 43

19. Drilling and Casing Capital costs . . . . . . . . . 50

20. Insulated Pipe costs ............. 51

21. Klamath Basin Chemical Composition of Cold and Heated Groundwater ............... 54

22. Commercial and Industrial Conventional Energy Price Projections ................ 61

23. Process Temperatures for Potential K1 amath Basin Products . 65

24. Existing Klamath Basin Agricultural Crops and Their Required Process Temperatures (1977) . . . . . . . 66

25. Proctor Continuous Automatic Onion Dehydrator . . . . . 68

26. Single-Line Onion Dehydrator ........... 73

27. Temperature and Energy Requirements for Each Compartment 74

28. Design I--Single-Line Onion Dehydrator Using $230^{\circ} \mathrm{F}$ Geothermal Water and $40^{\circ} \mathrm{F}$ Ambient Air . . . . . . 76

29. Design II--Single-Line Onion Dehydrator Using $230^{\circ} \mathrm{F}$ Geothermal Water and $65^{\circ} \mathrm{F}$ Ambient Air. . . . . . . . . 77

30. Design III--Single-Line Onion Dehydrator Using $220^{\circ} \mathrm{F}$ Geothermal Water and $40^{\circ} \mathrm{F}$ Ambient Air. . . . . . . 78

31. Single-Line Onion Dehydrator Layout of Plant and Wells . 79

32. Onion Dehydration Plant Break-Even Analysis for Operating Hours . . . . . . . . . . . . . . 83

33. Pelletized Alfalfa Processing Steps . . . . . . . . 88

34. Alfalfa Drying Plant and Well Layout . . . . . . . 91

35. Alfalfa Drying Plant Break-Even Analysis for Tons of Product ................ 996 
36. Alfalfa Drying Plant Break-Even Analysis for Operating Hours.............. . . . . . . . . 97

37. Western Polymer Corporation Layout of Existing Well and Transmission Lines .. . . . . . . . . . . . 100

38. Western Polymer Corporation Potato Starch Dryer . . . . . 101

39. Heating Pipe Network for Greenhouse at Hveragerdi, Iceland ........................... 114

40. Unit Heating System Design . . . . . . . . . . . 174

41. Fifteen-Acre Greenhouse Complex . . . . . . . . . . . 116

42. Processing Stages--Còmposite Flow Sheet . . . . . . . 127

43. Quintuple-Effect Evaporators . . . . . . . . . . . 130

43A. Quintuple-Effect Evaporator Flow Diagram . . . . . . . 131

44. Total Flow Method.................. 135

45. Evaporator Heat Exchanger Configuration . . . . . . . 136

46. Temperature Profile of First-Effect Heat Exchanger . . . . 136

47. Amal gamated Sugar Company Flow Diagram for Geothermal Conversion .................... . . 141

48. Amalgamated Sugar Company Plant and Weil Layout . . . . . 142

49. Ore-Ida Foods, Inc. Schematic Process Flow Chart . . . . 147

50. Ore-Ida Foods, Inc. Flow Diagram for Geothermal Conversion .................... 150

51. Ore-Ida Foods, Inc.

52. Cross-Section of Transmission Line . . . . . . . . . 153

53. Ore-Ida Foods, Inc. Control Diagram for Geothermal 154

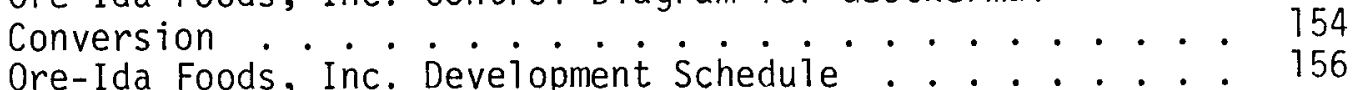




\section{INTRODUCTION}

\section{A. General}

The study of geothermal energy utilization potential for agribusiness industries in the Klamath and Western Snake River Basins, Oregon, was conducted by Oregon Institute of Technology's Geo-Heat Utilization Center, the Oregon Department of Geology and Mineral Industries, and the Oregon Department of Economic Development, under ERDA contract EY-76-S-07-1621. This is the final report for the program which spanned the period from 1 October 1976 to 31 March 1978.

The project activity included contributions from the following personnel:

$$
\checkmark \text { oregon Institute of Technology } 950085
$$

Paul J. Lienau

Charles V. Higbee

Principal Investigator

Saul Laskin

Economic Analysis

John W. Lund

Engineering

Engineering

$\checkmark$ Oregon Department of Geology and Mineral Industries

$\begin{array}{ll}\text { Donald A. Hul1 } & \text { Resource Assessment } \\ \text { Richard Bowen } & \text { Resource Assessment, Western } \\ & \text { Snake River Basin } \\ \text { Norman Peterson } & \text { Resource Assessment, Klamath } \\ & \text { Basin }\end{array}$

J Oregon Department of Economic Development

James E. Curtis Industry Contacts, Klamath

John N. Groupe Industry Contacts, Western

Snake River Basin

As indicated in Appendix D, many organizations cooperated with the investigators by providing supporting information during the course of this project.

The work described in this report was conducted for the Division of Geothermal Energy, Department of Energy (DOE). John L. Griffith, Idaho National Engineering Laboratory, Idaho Falls, Idaho, is the Project Manager.

\section{B. Objective}

The objective is to investigate the potential use of geothermal energy for direct heat applications in existing and prospective food processing plants located in two geothermal resource areas of Oregon.

To develop an awareness in the agribusiness community of the existence and extent of the geothermal resource, the means of exploiting the resource and the economics associated with the utilization. 


\section{SUMMARY AND CONCLUSIONS}

The primary results and conclusions of the work discussed in the following sections of this report are summarized in this section.

The two areas chosen for study have known geothermal resources in potentially significant amounts and additionally are in regions with welldeveloped, agricultural-based economies. The Klamath and Western Snake River Basins share many geologic characteristics, the principle identifying characteristic is the tensional faulting that has broken the region into a series of linear valleys and mountain ranges. Other significant characteristics shared by the two areas are widespread late Cenozoic volcanism, lake basin sedimentation, and the presence of thermal springs.

In the Klamath Basin there is a wealth of information on the location of near-surface geothemal waters and of practical methods of utilizing this resource, but little information on deeper rocks and how they may be affecting the presence of the shallower geothermal waters.

From this and other studies of the $\mathrm{K}$ lamath Basin, it appears the regional geothermal gradient is near $75^{\circ} \mathrm{C}$ per $\mathrm{km}$. If the regional gradient is in the range of $75^{\circ} \mathrm{C}$ per $\mathrm{km}$, water with sufficient temperature for space heating $\left(45^{\circ}\right.$ to $\left.50^{\circ} \mathrm{C}\right)$ can be expected to occur regionally at depths of 1,500 to 2,000 feet. Zones of upwelling higher-temperature waters $\left(90^{\circ}\right.$ to $100^{\circ} \mathrm{C}$ ) have been found and should be expected adjacent to faults. And, it is probable that deeper drilling to depths of 2,500 to 3,200 feet will intersect waters at least as high as $130^{\circ} \mathrm{C}$, the estimated reservoir base temperature in the region.

The Klamath Basin geothermal systems have a very great potential for space heating and industrial applications. Calculated estimates by White and Williams. (1975) of the thermal energy that can be applied directly to its intended direct use (assuming 25 percent of the stored energy recovered at the surface and efficiency of utilization also 25 percent) is $1.5 \times 10^{18}$ calories and if this useable heat were to be supplied by electrical energy, it would require $1,990 \mathrm{MW}$-century. The heat content in the shallow-water system is estimated to be in the range of $12 \times 10^{18}$ to $36 \times 10^{18}$ calories and could be one of the largest in the United States.

In the Western Snake River Basin deep drilling for suspected occurrences of $0 i 1$ and natural gas have provided a general knowledge of the existence and depths of deep potential geothermal reservoirs, but because the nearsurface indications of hot water are sparse, there has been little development of the type that is being practiced in the Klamath Basin.

Surface hot springs, thermal gradients, water we 11 temperature and regional geologic, hydrologic, and geophysical studies were all used to determine potential geothermal resource targets shown on individual 
resource assessment maps. In the Snake River Basin a higher-than-normal heat flow is present and favorable temperatures can be predicted at reasonable depths. The measured and projected geothermal gradients have been the main indicators of targets at shallower depths.

This study, along with others indicates the region has an average geothermal gradient of about $85^{\circ} \mathrm{C}$ per $\mathrm{km}$. The overlying Chalk Butte Formation has a consistent lithology of mostly tuffaceous siltstone and claystone with minor poorly sorted sand and gravel. Because of the consistent lithology a geothermal gradient measured in the upper 50 to $150 \mathrm{~m}$ can be expected to remain relatively constant until a differing lithology or a zone of moving groundwater is reached. By projecting the $85^{\circ} \mathrm{C}$ per $\mathrm{km}$ geotherma 1 gradient to $1.0 \mathrm{~km}$, the temperature at that depth can be assumed to be about $95^{\circ} \mathrm{C}\left(85^{\circ}+10^{\circ}\right.$ surface temperature $)$. Deeper wells in the same area drilled to the Owyhee Basalt would expect to penetrate 0.1 to $0.4 \mathrm{~km}$ of Grassy Mountain Basalt with a small increase in temperature to underlying Kern Basin Formation where a gradient of around $70^{\circ} \mathrm{C} / \mathrm{km}$ would be expected. Therefore, by drilling to the Owyhee Basalt about a kilometer below the Grassy Mountain Basalt, temperatures of about $165^{\circ} \mathrm{C}\left(95+70^{\circ} \mathrm{C}\right)$ can be expected.

Energy-economic needs and balances, along with cost and energy savings associated with field development, delivery systems, in-plant applications and fluid disposal have been determined for Western Polymer Corporation in the Klamath Basin and Amalgamated Sugar Company and and Ore-Ida Foods, Inc. in the Western Snake River Basin. In addition three prospective industries, which would be applicable in either basin, onion dehydration, alfalfa drying and greenhouses were studied.

\section{Western Polymer Corporation}

Western Polymer Corporation is located on the Oregon-California border 21 miles south of Klamath Falls and processes 14 tons of potatoes per hour for starch extraction. The plant consumes 122,250 gallons of propane annually, of which 85 percent is used for drying starch by means of cyclone separators.

Three options were considered in converting the plant to geothermal energy. The third and most attractive option considered drilling an existing 1,200-foot well to a depth of 3,000 feet in hopes of encountering $180^{\circ}$ to $200^{\circ} \mathrm{F}$ geothermal water. The water would be pumped through 300 feet of asbestos cement pipe to the preheat finned-tube water-to-air heat exchanger and supply $2.4 \times 10^{6} \mathrm{Btu} / \mathrm{hr}$ of the $3.5 \times 10^{6} \mathrm{Btu} / \mathrm{hr}$ required for starch drying. Reject water from the finned-tube heat exchanger would be used for space heating of the plant'. This system would supply 76 percent of the thermal energy requirements for space and process heat.

The total first-year cost for option three is $\$ 61,250$ intangible costs and $\$ 63,570$ tangible costs, for a total capital outlay of $\$ 124,800$. The intangible costs would be expensed in the first year, providing a tax reduction of $\$ 29,400$ for a net intangible cost of $\$ 31,850$. An investment tax credit of $\$ 12,714$ in the first year would be available on 
the tangible costs and with 200 percent declining balance depreciation assuming a ten-year life and 10 percent or less salvage value this option would provide a 27 percent return on investment and a payback period of slightly less than five years.

Onion Dehydration

Onion dehydration involves the use of a continuous operation, belt conveyor in four stages using fairly low-temperature hot air from $100^{\circ}$ to $220^{\circ} \mathrm{F}$. Typical processing plants will handle 10,000 pounds of raw product per hour (single-1ine), reducing the moisture from around 83 percent to 4 percent $(1,500$ pounds finished product). These plants produce 10 million pounds of dry product per year using from 0.15 to 0.20 therms per dry pound produced ( +0.06 therms of electrical energy), or 4,000 Btu per pound of water evaporated. The energy requirements for the operation of a dryer will vary due to differences in outside temperature, dryer loading, and requirement for the final moisture content of the product.

One type of processing equipment, the Proctor dehydrator, requires $86,500 \mathrm{ft}^{3}$ of air per minute and up to $40 \mathrm{milli}$ ion Btu per hour. Due to the moisture removal the air can in some cases only be used once, and thus is exhausted. Special silica gel--Bryair, dessications units are required in the final stage. The reject water from the Bryair preheater has a temperature of $192^{\circ} \mathrm{F}$; thus this could be used for space heating, greenhouses or other low-temperature energy needs. Approximately $\$ 200,000$ in fuel are thus used for a single-1ine dryer in a year's operation (180 days).

A design was made to convert the Proctor dehydrator to geothermal energy using a $20^{\circ} \mathrm{F}$ minimum approach temperature between the geothermal water and process air. A well with $230^{\circ} \mathrm{F}$ water is required for this. This temperature is available in the Klamath Basin; however, a deeper well $(2,000$ to 3,000 feet deep) will probably be required.

Since there currently are no onion dehydration plants in either basin, the cost analysis was done by investigating the cost difference in establishing a plant using conventional fuel (natural gas) versus geothermal energy. Assuming a 20-year operating life the total annual equivalent costs for the geothermal system (58 percent--production, 12 percent--delivery, and 30 percent--conversion) is $\$ 42,255$ plus $\$ 7.74$ per hour for electricity and natural gas for the Bryair. The total annual equivalent costs for the conventional system is $\$ 5,575$ plus $\$ 210$ per hour for energy costs. A break-even analys is indicates that the plant would have to operate only 180 hours per year in order to make the geothermal system competitive with natural gas.

Alfalfa Drying

There are several reasons for fuel drying the final alfalfa product instead of complete sun wilting. Fuel drying produces a harder and heavier pellet, and retains a greater percent of vitamin $A$ and xanthrophyll. 
Ideal1y, 100;000 to 125,000 international units of vitamin $A$ and xanthrophyll are needed; however, this can only be achieved by complete fuel drying. By field wilting and then some fuel drying, they can retain a minimum of 17 percent protein and an average of 55,000 international units of vitamin $A$ (xanthrophyll is assumed to be at about the same level as vitamin A). In addition, a bright green color is maintained that appears to improve the sellability of the product. Complete dehydration at this time does not appear to be economical and no new plants are being built along this line.

A plant that uses a combination of field wilt and fuel drying will produce 80 to 110 tons of pellets per eight-hour shift. The alfalfa is purchased (or costs the company) at $\$ 45$ to $\$ 55$ per ton standing (at 12 percent moisture), and costs an additional $\$ 20$ per ton to harvest and pellet. Of the total cost $\$ 2.50$ is due to the actual drying or about six gallons of fuel oil per ton of alfalfa. This fuel usage can range from 5 to 30 gallons per ton depending upon the moisture content and the ambient conditions. The total cost of pellets is $\$ 65$ to $\$ 75$ per ton, of which about $\$ 5$ per ton is the margin of profit. Thus, any fuel savings by converting to geothermal would have a significant percentage effect on the margin of profit. A geothermal energy conversion design was made for the combination field wilt and fuel drying. Using a $200^{\circ} \mathrm{F}$ air drying temperature for the dryer would require at least $220^{\circ} \mathrm{F}$ geothermal water. One well could provide the required flow, with one injection well for the reject water. Due to the high energy requirements and flow rates, a four-pass fixed water-to-air heat exchanger would be required.

Annual equivalent fixed costs for the geothermal system are $\$ 16,583$ (67 percent--production, 9 percent--delivery, and 24 percent--conversion) and require 362 operating hours annually in order to break even with a fuel oil-fired system. By using geothermal energy the harvesting and process costs would be cut from $\$ 20$ to less than $\$ 16$ per ton providing a 13.6 percent profit margin per ton of product. A plant producing 10,000 tons annually would require five years of operation to pay back the capital investment costs of a geothermal system at 9 percent per annum.

A facility that has an annual output of between 25,000 and 30,000 tons of pellets would realize a savings of $\$ 100,000$ per year over a conventional plant.

\section{Greenhouses}

Nearly every type of terrestrial commercial crop has been grown in greenhouses. The potential for the greenhouses to be used for specific crops was studied for the Klamath Basin. Tree seedlings for reforestation appear to be the most attractive crop at this time. Lower-temperature geothermally heated water can be utilized for greenhouses than for most agribusiness industries. Geothermal resources of temperature above $60^{\circ} \mathrm{C}$ have been used successfully for this application. However, heating greenhouses geothermally does require large quantities of water, especially if lower temperature of water are utilized. 
The greenhouse business benefits from the size or scale of operation. For purposes of this study a one-acre unit house is used as the basis for a 15-acre operation. An effort was made to determine the optimum design of a heating system for a 15-acre complex of greenhouses.

Cost differences between the conventional and geothermal heating systems were used in calculating the return on investment (ROI). Additional capital investment of $\$ 331,393$ is required for the geothermal system. The ROI calculation based on fuel savings yielded 162 percent.

\section{Amalgamated Sugar Company}

The Nyssa, Oregon sugar refinery is the seventh largest beet sugar processing plant in the United States. This plant can process 6,300 tons of sugar and 200 tons of molasses per day by means of the Steffen Process. When the plant is operating, 617 tons of coal are burned in the boilers per day. The plant converted from burning natural gas as its main fue] supply to coal in the early 1970s. Electric generators produce $5000 \mathrm{kw}$; in addition, $3000 \mathrm{kw}$ are purchased. Exhaust steam from the generators at 50 psia is used primarily for process in the first effect of the quintuple-effect evaporators. Approximately 110 pounds of steam per second are generated by the coal-fired boilers being consumed by the following: 75 percent to evaporators, 4 percent to turbines, 6 percent live steam to process, 10 percent to evaporation to form concentrated Steffen Filtrate (CSF) and pulp dryers, and 5 percent to steam venting and losses. The company is trying to reduce energy consumption by 20 percent.

The high use of energy in the evaporation process makes it an attractive candidate for conversion to geothermal energy. Two ways of doing this are apparent. One method would use the full flow of geothermal fluid through the first-effect evaporator. The second alternative would employ only steam flashed from the geothermal fluid in the first effect, the water fraction of the flow being discarded.

The flashed steam method was determined to be the most satisfactory method and assumed the geothermal fluid would be available at $327^{\circ} \mathrm{F}$ and 8.3 percent quality, fixing the enthalpy at $369 \mathrm{Btu} / 1 \mathrm{~b}$. If the fluid is throttled down to a pressure of about $49 \mathrm{psia}, 0.125$ pounds of steam will be available for each pound of geothermal fluid throttled. Further, this steam will be exactly at the conditions of the steam currently used. So, to obtain $77 \mathrm{lb} / \mathrm{sec}$ of steam, the quantity currently used, the quantity of geothermal fluid required would be about $620 \mathrm{lb} / \mathrm{sec}$. It is estimated that seven self-flowing wells would provide this flow rate. A 22-inch steam delivery 7 ine and 6 -inch condensate return 1 ine runs from the well field to the plant, a distance of 1,200 feet.

In 1964, Amalgamated obtained a 25-year coal contract at a price of $\$ 10$ per ton. With 12 years remaining on this contract the inflation rate for the next 12 years will consist of labor and transportation, which is currently $\$ 10.75$ per ton inflating at a rate of 7.5 percent 
annually. Pollution control equipment could be salvaged with a 68 percent loss resulting in a tax reduction of $\$ 648,000$ and a savings in maintenance costs. However, electric power cost would increase by $\$ 166,350$ per annum due to the shutdown of steam turbines.

Total annual savings before depletion and taxes equals cost of coal + pollution control maintenance - (increased power costs + geothermal system maintenance) with a 11 costs projected ten years at their respective inflation rates. The depletion allowance is subtracted from the total annual savings to lower federal taxes due to energy costs. A ten-year projection of cash inflow after taxes indicates a payback in the sixth year at a 20 percent ROI. A 26 percent ROI would be realized with a ten-year project 1 ife.

Ore-Ida Foods, Inc.

Ore-Ida Foods, Inc., a division of the H. J. Heinz Company, is located on the Oregon-Idaho border near the Snake River at Ontario, Oregon. Their major product is frozen potato products, processing over two million pounds of potatoes per day resulting in over one million pounds of frozen potato products.

Two natural gas-fired boilers supply an average of $120,0001 \mathrm{~b} / \mathrm{hr}$ of steam to process with 40 percent returned as a condensate. A11 processes except frying utilize direct injection of steam at 100 psig, which employs heat exchangers and steam at 275 psig. The fryers consume 45 percent of the energy of the plant and since the return temperature is greater than $300^{\circ} \mathrm{F}$, the assumed geothermal water supply temperature, 55 percent of the process energy requirements can be supplied by geothermal energy. It is estimated that the geothermal water temperature must be greater than $280^{\circ} \mathrm{F}$. The energy consumption for the 1976 calendar year was: heating--290,000 therms, processing-natural gas--4,394,326 therms, and 0i1, 816,081 gallons, at a total cost of $\$ 1,243,850$. Natural gas availability is dependent upon weather conditions and gas utility contracts.

To avoid any possible contamination of the product by the geothermal fluid, or the need for treatment of the fluid, energy is supplied to the process via intermediate heat exchangers which could be either of the she11-andtube design or the compact and versatile plate-type heat exchanger. Cost analysis for this study used the plate-type heat exchanger. The geothermal fluid passing through these exchangers will transfer energy to a secondary fluid, primarily water, which delivers the energy to the process. The secondary fluid, circulating in a closed system, then returns to the intermediate heat exchanger to be reheated. Energy requirements for the high-temperature processes $\left(200^{\circ} \mathrm{F}\right.$ or more) are satisfied by dropping the geothermal fluid temperature from $300^{\circ} \mathrm{F}$ to $190^{\circ} \mathrm{F}$. The lowertemperature processes are then supplied partially by this cooled-off geothermal fluid and partially by fresh geothermal fluid.

All of the secondary heat exchangers would be housed in a separate, new structure adjacent to the plant, along with the pumping and control equipment. 
A roughly 2,000-foot long pipeline would carry fresh geothermal fluid from the well field, on company-owned property, to the heat exchanger building and waste fluid would be carried back from the building to the injection well. With an anticipated temperature drop of $170^{\circ} \mathrm{F}$ for the geothermal fluid used to supply the $63.4 \mathrm{mill}$ ion Btu/hr needed for processing, roughly $370,000 \mathrm{lb} / \mathrm{hr}$ will be required. This should be readily available from two wells, with adequate margin for load variation or delivery rate fluctuation. The wells would be pumped to minimize temperature losses. A third well would be required for injection of the rejected fluid.

From the economic analysis for Ore-Ida Foods, Inc., a 30 percent ROI, or 3.6-year after-tax payback was calculated for a 15-year project 1 ife. The total after-tax dollars available at a 20 percent ROI for intangible drilling costs is $\$ 2.9$ million. Considering the after-tax cost of drilling an 8,000-foot wel1, the company could afford to drill eight wells and one injection wel1. In other words, with a geothermal resource confidence level as 10 as 25 percent, Ore-Ida Foods could still realize a 20 percent ROI. 


\section{II . RESOURCE ASSESSMENT}

\section{A. Introduction}

If geothermal energy is to be developed as a significant resource, it is necessary that it either be produced adjacent to or transported to areas of need. As yet, with the exception of electric power produced at The Geysers, the use of geothermal energy is restricted in the United States to within a very short distance of the production well. Today's technology and energy costs make it possible to deliver geothermal waters to distances up to $100 \mathrm{~km}$ depending upon the temperature of the water at the source, delivery point end-use, costs and availability of other energy supplies.

In vast regions of the western United States, geologic studies show that intermediate-temperature geothermal waters $\left(90^{\circ}\right.$ to $\left.150^{\circ} \mathrm{C}\right)$ can be 10 cated at depths ranging from 1 to $2 \mathrm{~km}$. In the part of the region where space heating is becoming an ever-increasing burden, the possibility of using geothermal energy for industrial uses, for institutional heating, or for district heating is becoming increasingly attractive. This assessment points out localities where the geothermal potential may exist, outlines the geothermal occurrences as known to date, infers reservoir data by comparison with known geothermal reservoirs, develops preliminary cost data and acquaints potential industrial users with the possibility of utilizing geothermal energy.

Two areas chosen for study have known geothermal resources in potentially significant amounts and additionally are in regions with well-developed, agricultural-based economies. The Klamath Basin and Western Snake River Basin share many geologic characteristics. Both are within the Basin and Range geologic province, a large region taking in much of southeastern Oregon, southern Idaho, western Utah, northern Arizona, parts of eastern California and most of Nevada. The principal identifying characteristic is the tensional faulting that has broken the region into a series of linear valleys and mountain ranges. Other significant characteristics shared by the two areas are widespread late Cenozoic volcanism, lake basin sedimentation, and the presence of hundreds of thermal springs.

In the Klamath Basin there is a wealth of information on the location of near-surface geothermal waters and of practical methods of utilizing this resource, but little information on the deeper rocks and how they may be affecting the presence of the shallower geothermal waters.

In the Western Snake River Basin deep drilling for suspected occurrences of oil and natural gas have provided a general knowledge of the existence and depths of the deep potential geothermal reservoirs, but because the near-surface indications of hot waters are sparse, there has been little development of the type that is being practiced in the Klamath Basin. 
Rationale for Selecting Geothermal Targets

Surface hot springs, warm-water wells, therma 1 gradients, water well temperature and regional geologic, hydrologic, and geophysical studies were all used to determine potential geothermal resource targets as shown on the individual resource assessment maps. In the Snake River Basin a higher-than-normal heat flow is present and favorable temperatures can be predicted at reasonable depths. The measured and projected geothermal gradients have been the main indicators of targets at shallower depths in both study areas.

By using the combination of measured and projected geothermal gradients, a total of several hundred data points were available in the study areas. Projected gradients were calculated from aquifer temperatures and depths recorded on drillers' logs for water wells. In most cases this method was limited to wells deeper than $50 \mathrm{~m}$ and in spite of inherent inaccuracies, the results have been quite useful. The projected gradients, when compared to measured gradients in nearby wells or the same well, were found to be reliable. Zones of higher-than-normal heat at shallower depth generally were found to be elongate and associated with fault zones that are known or inferred from geologic or geophysical studies.

\section{B. Klamath Basin Assessment}

1. Introduction

To determine the potential for increased utilization of natural hot water in parts of the Klamath Basin a growing list of published reports concerned with the geology, hydrology and geothermal resources have been reviewed. Interpretation of the information in the published reports, additional data from field examinations, and evaluation of hundreds of water well logs suggest several additional areas where adequate quantities of moderate-temperature water ranging from $40^{\circ}$ to $100^{\circ} \mathrm{C}\left(100^{\circ}\right.$ to $\left.210^{\circ} \mathrm{F}\right)$ may be found at reasonable depths from 500 to $1000 \mathrm{~m}(1,500$ to 3,000 feet $)$.

\section{a. Previous Work}

The geology of the area has been described in some detail by several reports including Newcomb and Hart (1958), Peterson and McIntyre (1970), and Sammel (1976). Groundwater resources in the Klamath Basin have been studied by Newcomb and Hart (1958), Illian (1970), and Leonard and Harris (1974). The geothermal resources in the $\mathrm{Klamath}$ Falls area have also been studied in some detail by Peterson and Groh (1967), Peterson and McIntyre (1970), Culver and others (1974), Sass and Sammel (1976), and Sammel (1976). These reports and others with some information about geology, hydrology, or geothermal resources are listed at the end of the report. 


\section{b. Geology}

The geologic studies show that even though the stratigraphy is not complex it is far from uniform. The structure is complex, however, and makes the understanding of the hydrology difficult.

A summary of the geology by Peterson and Groh (1967) gives the general picture and shows the Klamath Basin area to be underlain by a sequence of $\mathrm{Pliocene}$ and $\mathrm{Ple} i \mathrm{~s}$ tocene rocks that includes a lower unit composed of basaltic lava flows (0 to $250 \mathrm{~m}$ thick), overlain by a volcanic-sedimentary unit, the Yonna Formation (50 to $300 \mathrm{~m}$ thick), which is in turn overlain by a thinner unit of basaltic lava flows and breccias $(5$ to $30 \mathrm{~m})$. As indicated, thickness of the units and their lateral extent are not uniform and the units are probably interfingered deposits of lakes and streams that originated in a low relief terrain dominated by contemporaneous basaltic eruptions during Pliocene time. The Yonna Formation, volcanic and sedimentary rocks, are overlain by a variable thickness of lacustrine and alluvial sediments mainly in the structural valleys. The deeper basement rocks are not known but a recent, deep, geothermal well test encountered rocks similar to those of the Western Cascades (andesitic and basaltic lava flows, vari-colored volcanic breccias, and tuffs).

Faulting, some of which occurred in late Pleistocene time, has broken the whole Klamath Basin into a complex of northwesttrending fault block ridges (horsts) and intervening down-dropped (graben) valleys. Smaller tilted fault block protrude above the alluviated floors of the valleys.

The pattern of hot springs, hot-water wells, and hydrothermally altered rocks indicates geothermal activity over a long period of time at many places in the Klamath Basin including the city of Klamath Falls, Olene Gap, southwest Klamath Hills, and near Lorella in the Langell Valley.

Most of the geothermal anomalies appear as narrow, elongate zones paralleling major faults or fault blocks within the basin. This has led to one interpretation that the hot waters at Klamath Falls originate from deep circulation of meteroric waters with convective transfer of heat and fluid from depth through permeable zones along some of the major faults. Other interpretations have suggested a magmatic heat source.

The latest study, U.S. Geological Survey WRI 76-127, "Hydrogeologic Reconnaissance of the Geothermal Area Near Klamath Falls, Oregon," by E. A. Sammel (1976), concludes that the Klamath Falls area is underlain by an intermediate-temperature $\left(90^{\circ}\right.$ to $\left.130^{\circ} \mathrm{C}\right)$ convective geothermal system. This interpretation is based primarily on the geochemical temperature indicators (Renner and others, 1975) which the water in the reservoir reaches a temperature of $130^{\circ} \mathrm{C}$. Based on that reservoir temperature, Sammel (1976) concludes that the 
thermal waters in the area are produced by deep circulation along the fault zones to depths of 3 to $4.3 \mathrm{~km}(10,000$ to 14,000 feet) in a region of a normal geothermal gradient of $30^{\circ}$ to $40^{\circ} \mathrm{C}$ per $\mathrm{km}$. Based on the assumption that the hot water is produced through the mechanism of deep circulation in the fault zones, Sammel (1976) concludes that the hot waters are generally restricted to the three areas where they are now known, the Klamath Falls/ATtamont, KTamath Hil1s, and 07ene Gap regions.

The authors of this report bel ieve the hot waters are more abundant and widespread than does Samme 1 (1976) and base the assumption on the belief that the geotherma' gradient and therefore the heat flow of the region is much higher than the $30^{\circ}$ to $40^{\circ} \mathrm{C}$ per $\mathrm{km}$ regionat gradient reported by Sammel (1976), and Sass and: Sammel (1976). From this and other studies of the Klamath Basin made by the authors it appears the regional gradient is nearer $75^{\circ} \mathrm{C}$ per $\mathrm{km}$. If the regional gradient is in the range of $75^{\circ} \mathrm{C}$ per $\mathrm{km}$, water with sufficient temperature for space heating $\left(45^{\circ}\right.$ to $50^{\circ} \mathrm{C}$ ) can be expected to occur regionally at depths of 0.5 to $0.6 \mathrm{~km}$ ( $\mathrm{T}, 500$ to $2,000 \mathrm{feet})$. Zones of upswelling higher temperature waters $\left(90^{\circ}\right.$ to $\left.100^{\circ} \mathrm{C}\right)$ should be expected adjacent to faults. And, it is probable that deeper drilling to depths of 1.5 to $2 \mathrm{~km}$ wi 11 intersect waters at least as high as $130^{\circ} \mathrm{C}$, the reported reservoir base temperature in the region.

Even though the Klamath Basin geothermal systems may have only marginal potential value for generating electricity, they do have a very great potential for home heating and industrial applications. Calculated estimates by White and Williams (1975) of the thermal energy that can be applied directly to its intended nonelectric use (assuming 25 percent of the stored energy recovered at the surface and the efficiency of utilization also 25 percent) is $1.5 \times 10^{1.8}$ calories and if this useable heat were to be supplied by electrical energy it would require 1,990 MWcentury. The heat content in the shallow-water system is estimated to be in the range of $12 \times 10^{18}$ calories and could be one of the largest in the United States (Sammel, 1976 and White and Williams, 1975).

\section{c. Geothermal Potential}

To discuss the geothermal potential in an orderly way, eight subareas have been designated as shown on the index map; Figure 1. The most promising areas for additional hot-water resources border or are extensions of the three principal known geothermal areas (Klamath Falls, Klamath $\mathrm{Hills}$ and 01 ene Gap); however, several other targets with promising potential are indicated on the individual maps and discussed in the subarea reports. 
Figure 1.

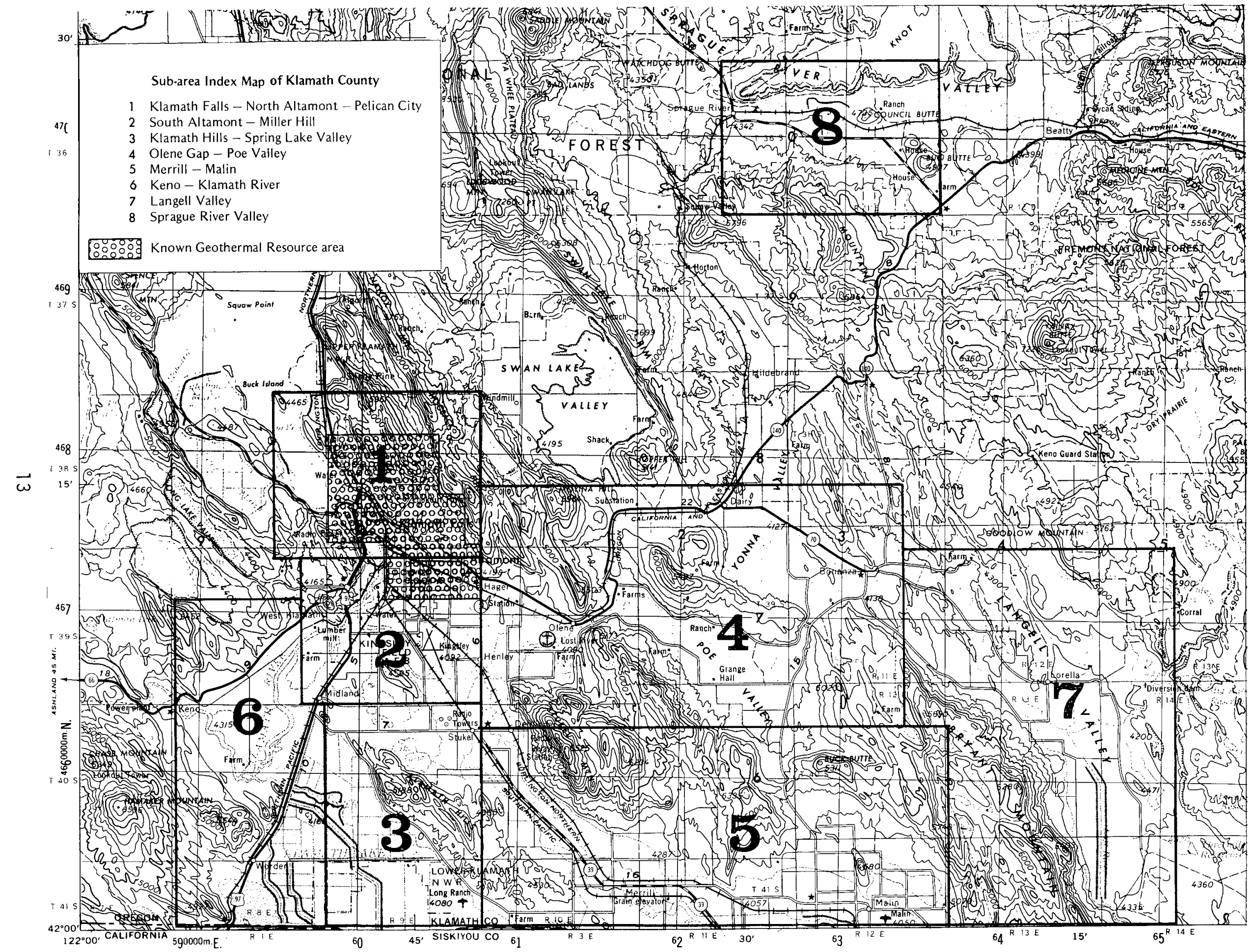


2. Subarea Assessment

\section{a. Klamath Falls/North Altamont/Pelican City}

The subarea designated at Klamáth Falls/North Altamont/Pelican City contains about $130 \mathrm{~km}^{2}$ (50 square miles), extends eastward from Upper Klamath Lake to Hogback Mounta in on the east, and from Cove Point/Wocus southward to Lake Ewauna and Altamont (Figure 2).

The urban area of $\mathrm{Klamath}$ Falls which contains the core of the well-known geothermal resource has not been tabulated in detail for this project as this has been done by Culver and others (1974). Extensions to the northwest, east and south of the urban area that have potential as sources of hot water for the agribusiness industry are shown by pattern on Figure 2 .

The area east of $\mathrm{Kl}$ amath Falls adjacent to the 01d Fort Road for about $2 \mathrm{~km}$ has some wells that show above-normal temperatures and gradients as well as hydrothermal rock alteration. This zone which extends east into the SW $1 / 4 \mathrm{sec} .22$ and the $W 1 / 2$ of sec. 27 , is considered to have a better-than-average potential for developing hot water.

A recent well drilled at the north end of Summers Lane in the SE $1 / 4$ of sec. 34 , produces $70^{\circ} \mathrm{C}$ water from $468 \mathrm{~m}$ and is used to heat the Shadow Hills apartment complex. This extends the known resource zone to the southeast. Another well just west of Washburn way in the NE 1/4 sec. 4, T. 39 S., R. 9 E., extends the developed hot-water zone to the south. This well produces $46^{\circ} \mathrm{C}$ water from $460 \mathrm{~m}$ depth and furnishes heat to the large Maywood Industries building.

The latest detailed study by the U.S. Geological Survey, WRI 76-127, "Hydrologic Reconnaissance of the Geothermal Area Near Klamath Falls, Oregon," by E. A. Sammel shows a broad zone including the area south of Klamath Falls from Lake Ewauna to Altamont within a $30^{\circ} \mathrm{C}$ isotherm where maximum temperatures from wells are $30^{\circ} \mathrm{C}\left(86^{\circ} \mathrm{F}\right)$ or above at moderate depths.

The area northwest of the known geothermal wells at Oregon Institute of Technology and the Presbyterian Intercommunity Hospital is essentially untested; however, similar geology and rock alteration indicates that this zone extends as far as the SW $1 / 4$ of sec. 17, T. 38 S., R. 9 E., and is considered to be a good target.

If an agribusiness were to consider locating in the Pelican City/ Industrial Park area, pumping of hot water from known geothermal sources nearby appears to be feasible. 


\section{KLAMATH FALLS - N. ALTAMONT-PELICAN CITY SUBAREA}

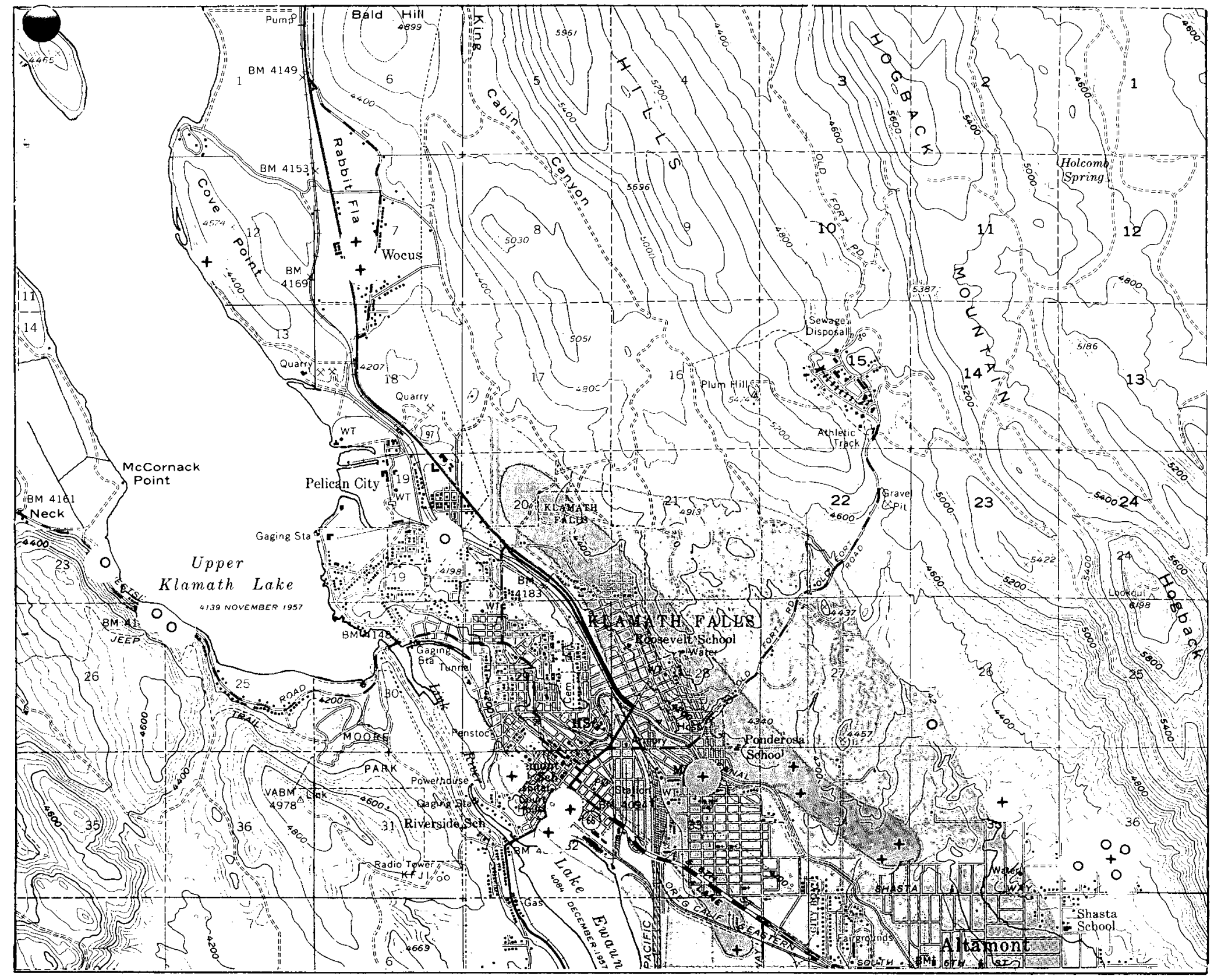

\section{LEGEND}

Greater than average potential for

hot water from $50^{\circ} \mathrm{C}$ to $100^{\circ} \mathrm{C}$ at depths of 500 to $1,000 \mathrm{~m}$.

Area where geothermal water has been developed for industrial or home heating use.
DRILL HOLE WITH GEOTHERMAL GRADIENT

0 Gradient $\leqslant 100^{\circ} \mathrm{C} / \mathrm{km}$

+ Gradient $>100^{\circ} \mathrm{C} / \mathrm{km}$ 


\section{b. South Altamont/Miller Hill}

The South Altamont/Miller Hill area covers about $100 \mathrm{~km}^{2}(40$ square miles) directly south of Klamath Falls and is almost all within T. 39 S., R. 9 E. Lake Ewauna and the headwaters of the Klamath River are in the northwest part, Midland and Miller Hill along the south boundary (Figure 3 ).

Several sites within this area appear to have above-average potential for reaching hot water in the range of $40^{\circ}$ to $100^{\circ} \mathrm{C}$ at depths of less than $1000 \mathrm{~m}$. One of the most promising is a narrow northwest-trending zone about $4 \mathrm{~km}$ long that extends from the KLAD radio transmitter station southeastward through Railroad Hill in sec. 9 to the Altamont/Summers Lane junction with Johns Avenue.

The other area already tested is along the northeast margin of the map extending southeastward beyond Wiard Park to the Hager area. The Mazama School well produces water of $60^{\circ} \mathrm{C}$ from $300 \mathrm{~m}$ within this zone. The south end of Miller Hill has also been tested and wells for the Falcon Heights subdivision in sec. 33 and others have water temperatures of near $40^{\circ} \mathrm{C}$ at $300 \mathrm{~m}$ and less. A shallow well at Midland in sec. 36, T. 39 S., R. 8 E. is also reported as warm and this area may have some potential. In the northwest corner of the area some recent wells in the north part of Stewart-Lennox and one at the Junction of Highway 66 and 97 show gradients of $110^{\circ}$ to $150^{\circ} \mathrm{C} / \mathrm{km}$ and may have some potential; however, this area will need further evaluation.

\section{c. Klamath Hills/Spring Lake Valley}

Included in this subarea is the well-known geothermal zone of the southwest flank of the Klamath Hills, the Spring Lake Valley to the north and a large part of the Lower Klamath Lake to the southwest (Figure 4). The hot-water zone shown on the area map is lens shaped, about $7 \mathrm{~km}$ long and at its widest point, near the center of the zone in sec. 27,34, T. 40 S., R. 9 E., it is about $1-1 / 2 \mathrm{~km}$ wide. It narrows in both directions to about $1 / 2 \mathrm{~km}$. At least four more successful hot wells have been drilled in 1976 in the hottest zone. While these wells have not been completely tested, all are estimated to be capable of producing $1,000 \mathrm{gpm}$ of $80^{\circ}$ to $90^{\circ} \mathrm{C}$ water. Other than the main producing zone some shallow wells along the north flank of the Klamath Hills are reported as warm. The only other area of interest is in the north where the southern extension of-the Miller Hill warm-water zone extends into the Spring Lake Valley in secs. 3 and 4, T. 40 S., R. $9 \mathrm{E}$.

The proven resource of relatively large volumes of hot water in this agricultural area make it one of the prime areas for development. 


\section{S. ALTAMONT - MILLER HILL \\ SUBARE A}

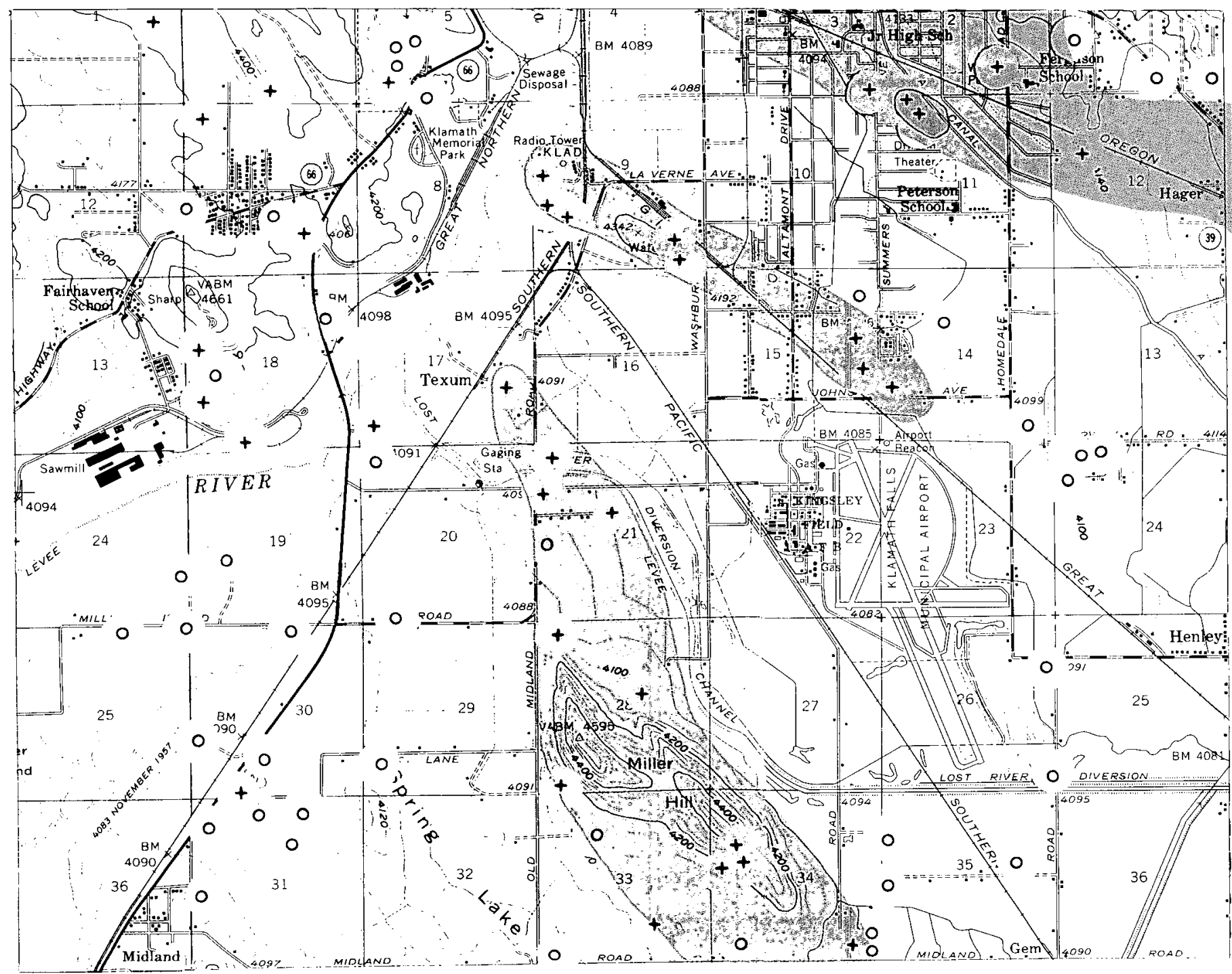

\section{LEGEND}

Greater than average potential for

hot water from $50^{\circ} \mathrm{C}$ to $100^{\circ} \mathrm{C}$ at depths of 500 to $1,000 \mathrm{~m}$.

Area where geothermal water has been developed for industrial or home heating use.

DRILL HOLE WITH GEOTHERMAL GRADIENT

O Gradient $\leqslant 100^{\circ} \mathrm{C} / \mathrm{km}$

Figure 3.

+ Gradient $>100^{\circ} \mathrm{C} / \mathrm{km}$ 


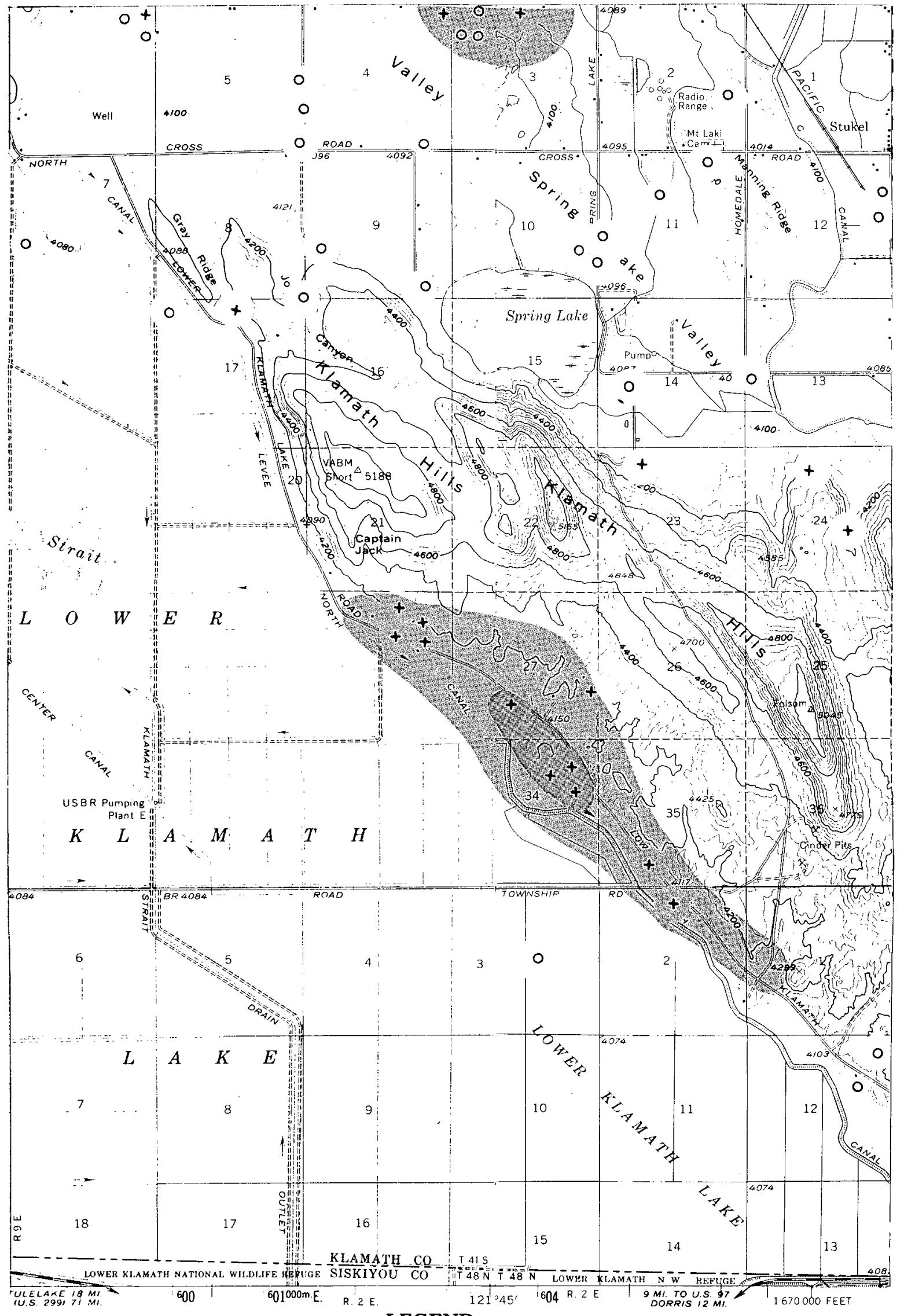

\section{LEGEND}




\section{d. Olene Gap/Poe Valley}

The 0lene Gap/Poe Valley subarea includes the northwest part of Stukel Mountain, the Pine Grove area, 0lene, all of Poe Valley, and the southern part of the Yonna Valley as far east as Bonanza as outlined on the subarea map (Figure 5).

A review of the geology, surface, and subsurface temperatures indicate that the highest potential for geothermal fluids is in the 01 ene Gap area. The hot springs there were recently measured for temperature and flow while the Lost River was at its lowest level and most of the spring orifices were exposed in the river bed. Temperatures measured ranged from $70^{\circ}$ to $81^{\circ} \mathrm{C}$ at $\mathrm{six}$ separate spring vents on the south bank of the river, south of the bridge, and the largest spring in the concrete culvert north of the flume on the north bank of the river had the highest temperature at $87^{\circ} \mathrm{C}$. A traverse of the north shore of the river shows several areas of warm ground between the bridge and flume. The total volume of water flowing from the springs at 0lene Gap was estimated to be from 30 to $50 \mathrm{gal} / \mathrm{min}$. Water we 11 projected thermal gradients both east and southwest of the gap indicate that the geothermal anomaly extends some distance to the east and also to the south.

The next best potential area is connected with the 0lene Gap anomaly and extends south and westward in a zone one-half to one mile wide surrounding Nuss Lake and extends west and south around the northwest point of Stukel Mountain in sec. 32, T. 39 S., R. $10 \mathrm{E}$. High projected gradients in water wells $\left(100^{\circ}\right.$ to $\left.500^{\circ} \mathrm{C} / \mathrm{km}\right)$ occur on the west side of Stukel Mountain between Dehlinger and Wilson Bridge. High gradients are also present in the zone both west and north of Nuss Lake to Crystal Springs and 0lene.

Another area that shows a higher-than-normal geothermal potential is located at the south end of Hogback Mountain straddling the junction of Highway 140 and the Merrill Highway in secs. 6 and 7 , T. 39 S., R. $10 \mathrm{E}$. This appears to be the southeasternmost extension of the Klamath Falls geothermal zone.

Two smaller areas that need more information points but that may have some potential are located in the northeast part of Poe Valley on the west and south flank of the faulted volcano that separates the Poe and Yonna Valleys.

\section{e. Subarea Five, Merri11/Mal in}

The Merri11/Mal in area includes most of the agricultural land north of the California line from Bryant Mountain east of Malin to the eastern part of the Klamath Hills on the west. It also extends north and west on both sides of Lost River along the southwest flank of Stukel Mountain. 
OLENE GAP-POE VALLEY SUBAREA

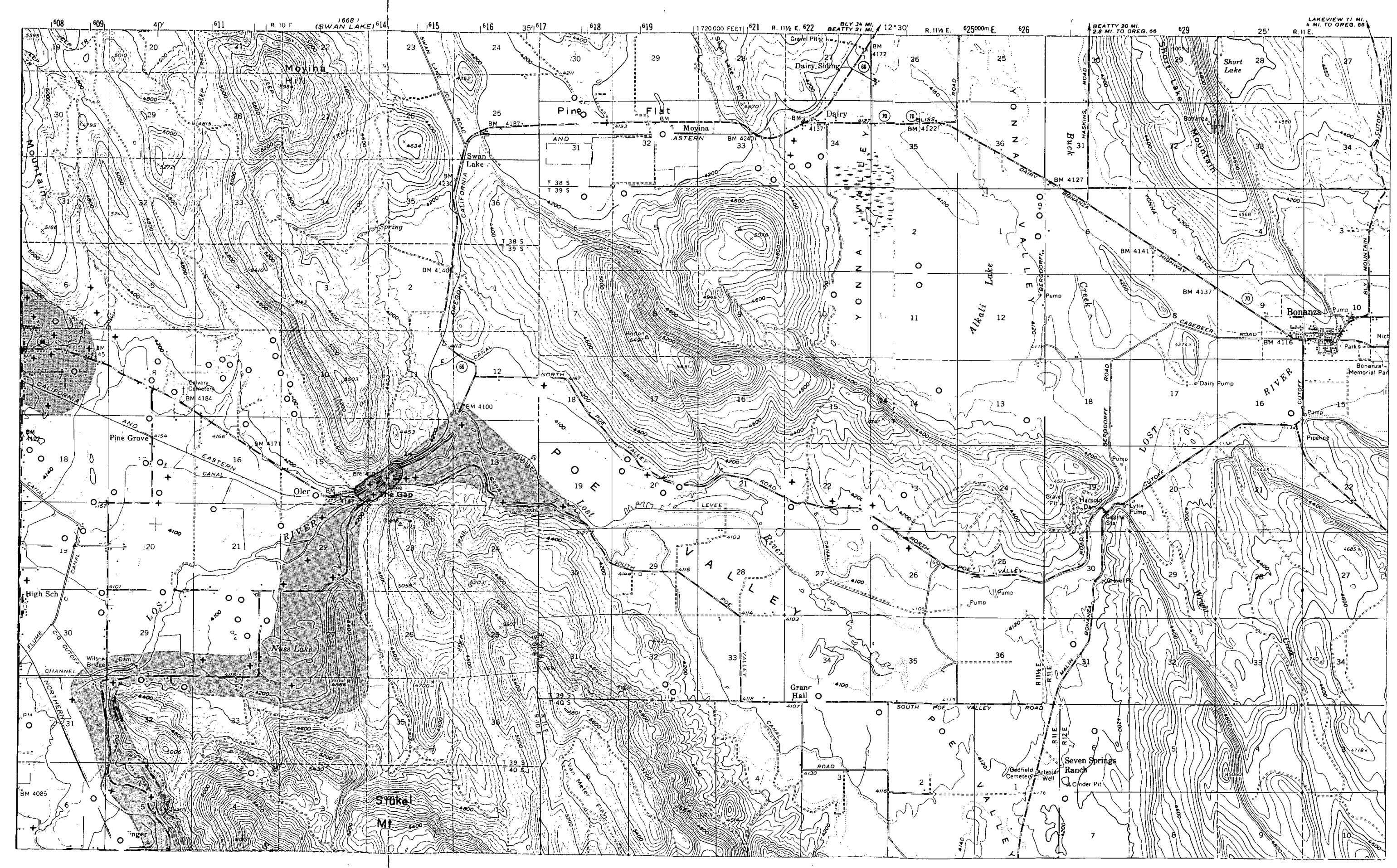

LEGEND

Figure 5 .

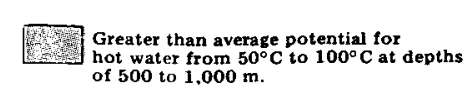

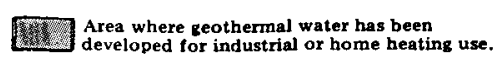

DRILL HOLE WTth GEOTHERMAL GRADIENT

Gradient $<100^{\circ} \mathrm{C} / \mathrm{km}$
+ Gradient $>100^{\circ} \mathrm{C} / \mathrm{km}$ 
A study of springs and well logs indicates several areas of moderate-temperature $\left(50^{\circ}\right.$ to $\left.100^{\circ} \mathrm{C}\right)$ geothermal potential and these are outlined on the sketch map (Fiqure 6).

They are listed here in the authors' interpreted order of highest potential. No. 1 - An elongate area near the northwest corner of the map along Hill Road and the west flanks of Stukel Mountain in secs. 8,9 , and 16, T. 40 S., R. $10 \mathrm{E}$. Well 1 ogs report temperatures of $22^{\circ}$ to $30^{\circ} \mathrm{C}$ at depths of 55 to $75 \mathrm{~m}$. Projected gradients for this area range from $133^{\circ}$ to $290^{\circ} \mathrm{C} / \mathrm{km}$.

No. 2 - An area on the south side of Stukel Mountain in secs. 25, 26, T. 40 S., R. $10 \mathrm{E}$., and extending eastward and southward to Adams Point half way between Merrill and Malin. The most promising part of this area is the northwest part where projected gradients range from $100^{\circ}$ to $218^{\circ} \mathrm{C} / \mathrm{km}$ in several wells.

No. 3 - Three smal1 areas northwest and south of Merrill in the easternmost part of the Klamath $\mathrm{Hills}$ show higher than normal gradients $130^{\circ}$ to $160^{\circ} \mathrm{C} / \mathrm{km}$. They also produce large water volumes and the potential for a geothermal resource in the range of $50^{\circ}$ to $70^{\circ} \mathrm{C}$ is above average. These could represent a continuation of the geothermal zone along the south side of the Klamath Hills.

f. Keno/Klamath River

This area includes large blocks of agricultural land flanking the headwaters of the Klamath River southwest of Klamath Falls and east of Keno and the western part of Lower Klamath Lake (Figure 7). The only part of this large area that shows thermal gradients over $100^{\circ} \mathrm{C} / \mathrm{km}$ is in the northeast corner in secs. 14 and 23, T. $39 \mathrm{~S}$., R. $8 \mathrm{E}$., where several wells drilled in 1976 in the Lawanda Hills Subdivision produce water from $18^{\circ}$ to $22^{\circ} \mathrm{C}$ at depths ranging from 50 to $100 \mathrm{~m}$. Gradients in this area range from $95^{\circ}$ to $171^{\circ} \mathrm{C} / \mathrm{km}$. Water volumes reported are from 20 to $100 \mathrm{gal} / \mathrm{min}$. This small area needs to be evaluated further. Another single anomalous water well with a measured gradient of $150^{\circ} \mathrm{C} / \mathrm{km}$ is reported by Samme 1 (1976) in sec. 10, T. 40 S., R. 8 E. Otherwise a general lack of information in the western and southern part of the area from Keno to the California border prevents a meaningful evaluation.

\section{g. Langell Valley}

The Langell Valley subarea covers about $260 \mathrm{~km}^{2}$ and is basically the broad northwest-trending valley of the Lost River from where it enters Oregon at the south to Bonanza in the northwest (Figure 8).

A review of water well logs and other data shows the temperature of the shallow groundwater to be generally normal or below normal, except for three relatively small elongate zones in the central and south part of the valley. 
MERRILL-MALIN SUBAREA

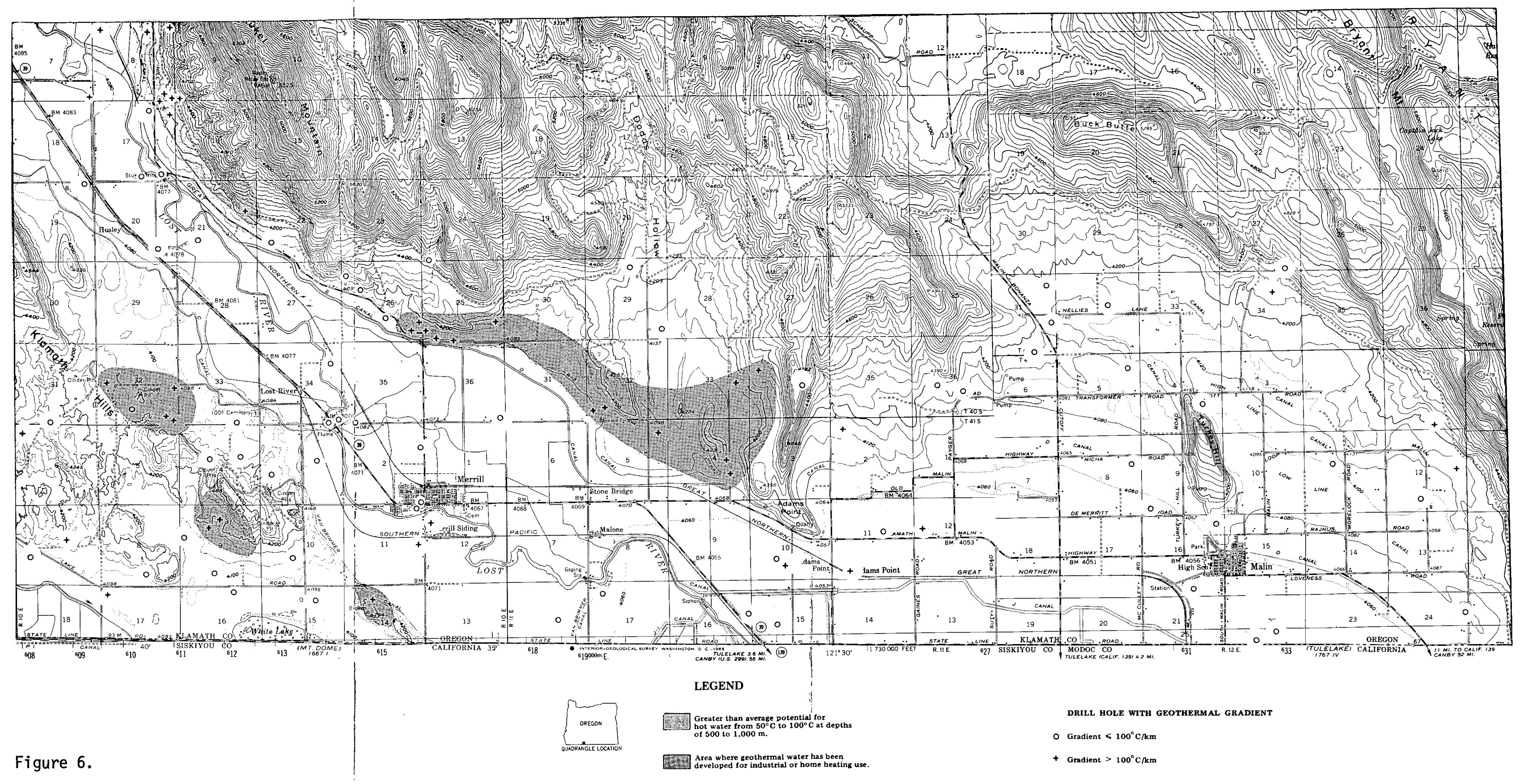


KENO-KLAMATH RIVER SUBAREA

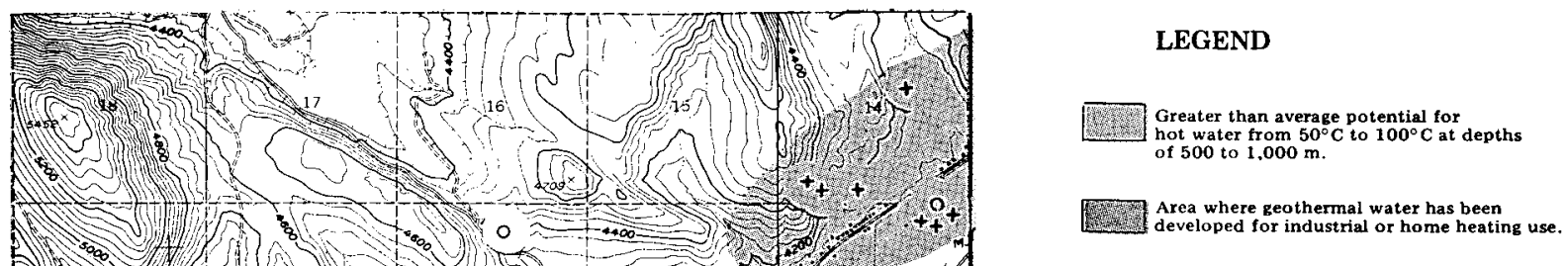

DRILL HOLE WITH GEOTHERMAL GRADIENT
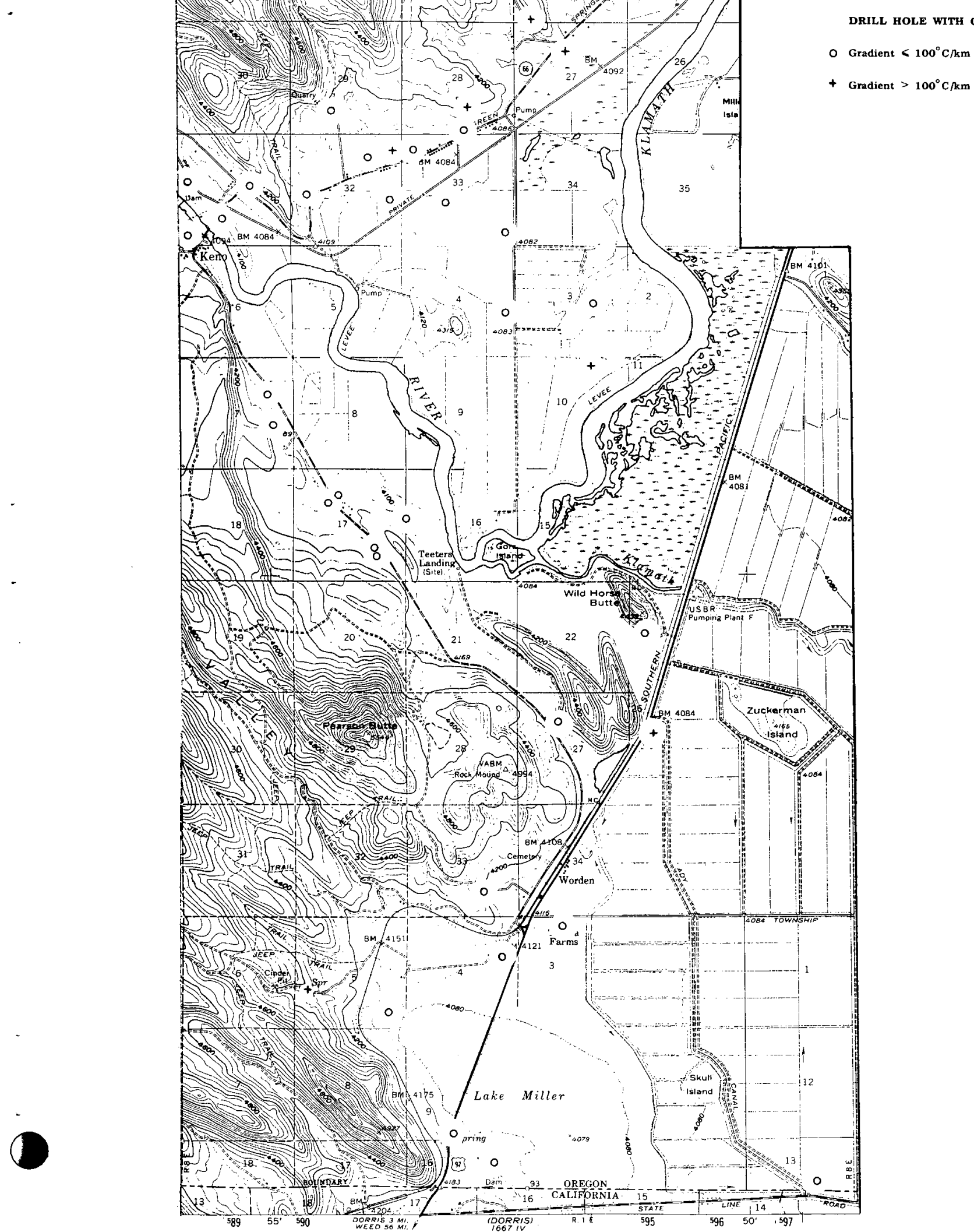

Figure 7. 
LANGELL VALLEY SUBAREA

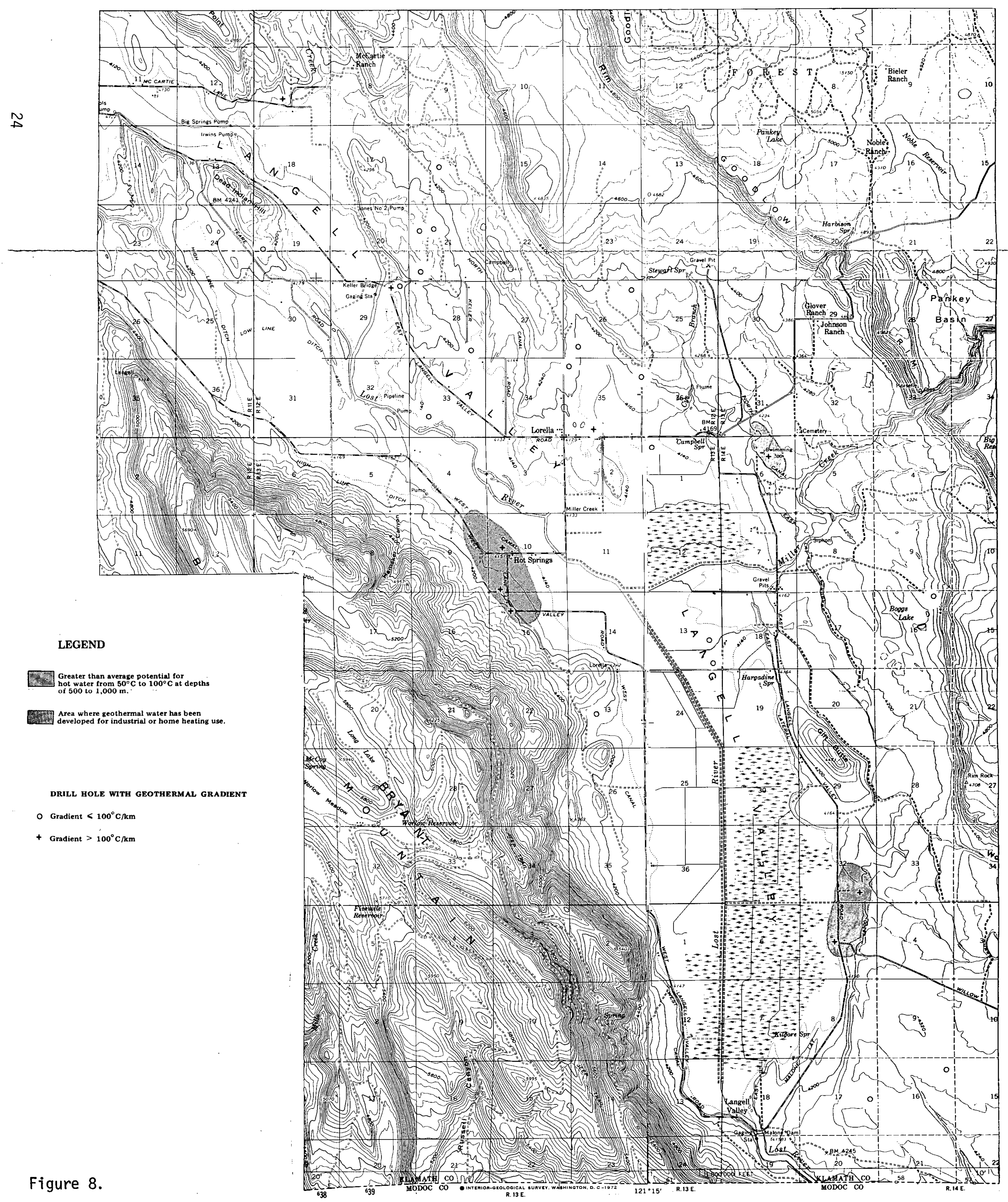


The highest potential for geothermal fluids is in a narrow northwest-trending zone that includes the Turner or Big Hot Spring southwest of Lorella. This spring is reported to flow $40 \mathrm{ga} 7 / \mathrm{min}$ of $61^{\circ} \mathrm{C}$ water.

Another area of higher-than-normal heat flow is located about three miles east of Lorella where a warm spring (Wilkerson or Patuchek) with $24^{\circ} \mathrm{C}$ water flows at $25 \mathrm{gal} / \mathrm{min}$.

The only other area of questionable potential is in the south part of Langell Valley and is indicated by wells in sec. 32, T. 40 S., R. 13 E., and sec. 5, T. 41 S., R. 13 E., with gradients of $151^{\circ}$ and $240^{\circ} \mathrm{C} / \mathrm{km}$. There are a few other scattered wells throughout the valley with thermal gradients above $100^{\circ} \mathrm{C}$ but with the few points of information available no meaningful predictions about hot-water potential can be made.

h. Sprague River Valley

The subarea designated as the Sprague River is all of T. $36 \mathrm{~S}$., R. $12 \mathrm{E}$., and al1 but six square miles of T. $36 \mathrm{~S}$., R. $11 \mathrm{E}$. (Figure 9). Newcomb and Hart (1958) reported wells with abovenormal temperatures in the Sprague River Valley east of the town of Sprague River. A review of water well logs show some projected gradients of $100^{\circ} \mathrm{C} / \mathrm{km}$ but a majority of the information indicates a less-than-average potential for reaching favorable water temperatures at a depth of 1 ess than $1 \mathrm{~km}$; however, there are no deep tests to help in evaluating this subarea at the present time.

\section{Western Snake River Basin Assessment}

1. Introduction

The presence of hot springs and of hot irrigation wells around the margins of the Western Snake River Basin indicate the presence of a considerable untapped reserve of geothermal energy underlying the region. Figure 10 shows the location and extent of the study area, the pattern of faulting and the known thermal springs and wells. The agribusiness industry consumes considerable quantities of relative low-temperature heat in the range of $60^{\circ}$ to $150^{\circ} \mathrm{C}$ (Reistad, 1975). If geothermal waters could be utilized for a portion of these energy requirements, a major savings in fossil fuels could be achieved by the region. Additionally, geothermal resources could provide for a reliable energy source at stable prices assuring the economy of the region a good competitive position against other areas that are facing rising prices of fossil fuels. The key to this utilization is knowledge of the location, temperature and quality of the resource.

The primary factors to be considered here are the location, depth to the reservoirs, temperature, well productivity, and cost of production. This study attempts to provide a geologic background of this information so decisions can be made to explore with a knowledge of all of the geologic information available at this time. 


\section{a. Previous Work}

Corcoran and others (1962) mapped the geology of Mitchell Butte 30-min. topographic quadrangle and in doing so summarized the earlier work in the region and established many of the formation's names that are now used. Kittleman and others (1965, 1967) and Kittleman (1973) also published a geologic map of the region covering slightly more area than Corcoran. Newton and Corcoran (1963) prepared a reconnaissance map of the Western Snake River Basin and correlated the subsurface geoloqy across the region using the cuttings and electric logs from 20 exploratory $0 i 1$ and gas wells. Their work along with logs from a few wells drilled later have been used to establish the geologic conditions of the deeper part of the basin. Bowen and Blackwell (1975) published the first geothermal study of the area which has been used extensively in preparing this report. Geophysical studies have been made in the area by Long, Hoover and Bramsoe (1975), who produced a map showing apparent electrical resistivities at specific frequencies. Couch (1977) and Couch and Baker (1977) published the results of gravity and seismic studies in the area. The study by Couch (1977) summarized both the gravity and seismic studies, presented a fault map of the region and synthetic cross-sections for a region south of Vale. The gravity data in particular seems to correlate the surface and subsurface geologic studies as it shows nearly a 71 the therma? springs to be in zones of high gravity gradient, a characterization of faults. This relationship of faulting with thermal springs is shown in Figure 10.

\section{b. Geology}

The Western Snake River Basin is part of a much larger structural depression known as the Snake River Plain, that extends eastward from the Oregon border across southern Idaho to Yellowstone Park in Wyoming. The western part is mainly filled with fine-grained nonmarine sedimentary rocks with interbedded sequences of lava flows. The basin has been interpreted by some as a large complex graben with bounding normal faults. Figure 11 shows the general stratigraphy and some of the interpreted structure in the study area. Basaltic lava flows (Owyhee Basalt), the lowermost rocks of interest are Middle Miocene in age and correlated with the Columbia River Basalt. Above the Owyhee Basalt are lacustrine and fluvial sedimentary rocks of the Dear Butte Formation and Kern Basin Formation. Another sequence of basaltic lava flows, the Grassy Mountain Basalt, is overlain by Pliocene lake sediments of the Chalk Butte Formation, which are the predominant surface rock type. Regional dips of the layered rocks are generally at low angles to the east or toward the center of the basin. Estimated thickness of formations and their depth below the surface is portrayed in Fiqure 11 . 


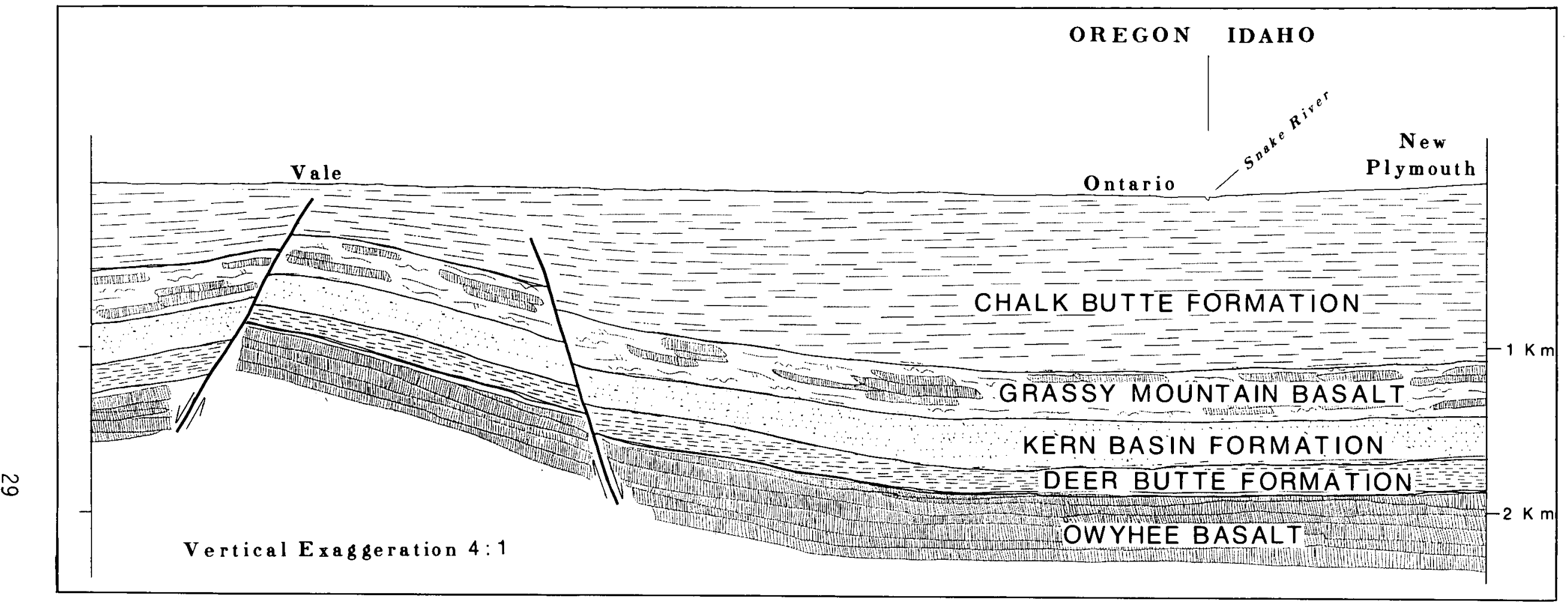

This cross section shows the relationship of the geologic structure and stratigraphy underlying the Western Snake River Basin study area. Owyhee Basalt and Grassy Mountain Basalt are considered to be the principal reservoir rocks in the region as they are the only ones having the porosity and permeability that wizl permit large withdrawals of water necessary to support space heating or process-heating uses. The fault zone at Vale opens a path of migration for geothermal fluids from underlying reservoirs to near the surface. 


\section{c. Geothermal Potential}

A number of conditions must exist if a geothermal deposit is to be economically viable: 1) it must be of sufficient temperature for its intended use; for electric power production temperatures should be $150^{\circ} \mathrm{C}$ or greater. For space heating, temperatures of $50^{\circ}$ to $150^{\circ} \mathrm{C}$ are useful, depending upon the particular use.

2) There must be a sufficient volume of geothermal fluid in the reservoir to maintain production for 30 to 50 years, or there must be hydrologic conditions that allow recharge of the reservoir. 3) The system must be confined by a relatively impermeable barrier so a trap is formed, thereby allowing the fluids to accumulate.

So far there has been no production of geothermal waters in the region except for a few shallow wells near Vale Hot Springs; however, the presence of other hot springs and warm-water well is in various parts of the area, along with the background knowledge of the subsurface geology from the $0 i 1$ and gas tests drilled in the basin, indicate that the required conditions for nonelectric utilization outlined above are present. A detailed discussion of the individual thermal water occurrences and interpreted geothermal targets is made in the individual subarea resource assessments.

In addition to the specific geothermal targets associated with faults and outlined on the subarea maps, the generally higher-thannormal regional heat flow makes the feasibility of locating hot water most anywhere in the study area possible. Fluids at useable temperatures can probably be located by drilling to either the Grassy Mountain or the Owyhee Basalt.

This study, along with others (Bowen and Blackwel1, 1975; Hul1, 1975 ) indicates the region has an average geothermal gradient of about $85^{\circ} \mathrm{C} / \mathrm{km}$. Because of the reliance on geothermal gradients in predicting subsurface temperature conditions in this study, individual profiles of many of the measured geothermal gradients are shown in Figure 12. Also shown for comparison are lines that represent geothermal gradients of $70^{\circ}$ and $100^{\circ} \mathrm{C} / \mathrm{km}$. Most gradients are linear, indicating consistent rock thermal conductivity. The nonlinear geothermal gradients, such as 19S/46 F - 15DC and 17S/45 E -11DC represent water movement in the bore hole or within the formation. By projecting this regional geothermal gradient to the depths where the basaltic reservoir rocks are expected to occur, an estimation of reservoir temperatures can be made. For example, in the region between Ontario and Nyssa the top of the Grassy Mountain Basalt is expected to be at a depth of between 1 and $1.2 \mathrm{~km}$. The overlying Chalk Butte Formation has a consistent lithology of mostly tuffaceous siltstone and claystone with minor poorly sorted sand and gravel. Because of this consistent 1ithology, a geothermal gradient measured in the upper 50 to $150 \mathrm{~m}$ can be expected to remain relatively constant until a differing lithology or a zone of moving groundwater is reached. By projecting the $85^{\circ} \mathrm{C} / \mathrm{km}$ geothermal gradient to $1 \mathrm{~km}$, the temperature at that depth 


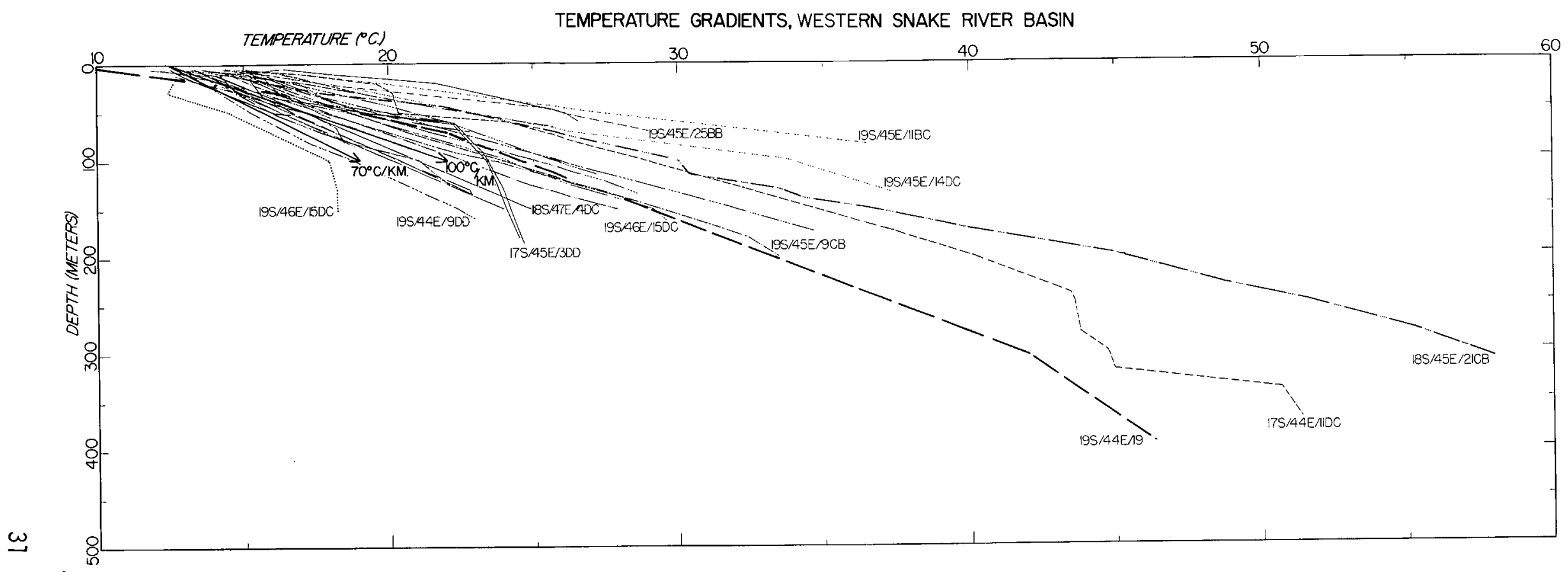

Profiles are designated by location of Township, Range and Section and by 1/4,1/4 section. The alphabetical designation of $1 / 4$ and $1 / 4,1 / 4$ section follows the USGS Water Resources publication practice. A represents the NE $1 / 4, B$ the NW, $C$ the SW and D the SE. Therefore, a location given as 19S/45E/11BC is in Township 19 South, Range 45 East, $\overline{S W}$, NW Sec 11 . Two profiles, $70^{\circ} \mathrm{C} / \mathrm{km}$ and $100^{\circ} \mathrm{C} / \mathrm{km}$, are shown to illustrate the slopes represented by these gradients. The highest shown, $19 \mathrm{~S} / 45 \mathrm{E} / 1 \mathrm{lBC}$, is approximately $250^{\circ} \mathrm{C} / \mathrm{km}$. This hole is located just south of Vale on the Willow Creek Fault zone. With only a few exceptions, probably caused by circulating water, the profiles tend to be linear. The general decrease in gradient with depth in the deeper holes, 19S/44E/19, and 18S/45E/21CB, is due to the presence of basalts that because of higher thermal conductivity show decreased gradient for a given heat flow. The sharp gradient change in 19S/44E/11DC, 19S/46E/15DC and 17S/45E/30DD is probably due to flows of water within the well bore. The Parma, Idaho well was logged before temperatures stabilized and still shows some of the effects of drilling. 
can be assumed to be about $95^{\circ} \mathrm{C}\left(85^{\circ}+10^{\circ}\right.$ surface temperature $)$. Deeper wells in the same area drilled to the Owyhee Basalt would expect to penetrate 0.1 to $0.4 \mathrm{~km}$ of Grassy Mountain Basalt with a small increase in temperature to the underlying Kern Basin Formation. In the Kern Basin Formation the geothermal gradient will be only slightly lower because of the slightly higher conductivity of the more compact rocks, so a geothermal gradient of $70^{\circ} \mathrm{C} / \mathrm{km}$ is estimated. Therefore, by dril1ing $1 \mathrm{~km}$ below the Grassy Mountain Basalt, temperatures of about $165^{\circ} \mathrm{C}\left(95^{\circ}+70^{\circ}\right)$ can be expected.

If the anticipated use of the geothermal fluid in the range of $90^{\circ}$ to $100^{\circ} \mathrm{C}$ from the Grassy Mountain Basalt and $140^{\circ}$ to $165^{\circ} \mathrm{C}$ from the Owyhee Basalt can justify the costs necessary to drill to the 1- or 2-km depths, there is reasonable assurance that the resource can be located anywhere in the study area. Drilling costs are discussed in a later part of this report.

The Western Snake River Basin is divided into five subareas for the purpose of discussion in this report (Figure 13). The subarea maps indicate the locations of the known thermal springs and wells, the wells that were used to determine the geothermal gradients, and zones where fault-related geothermal waters are expected to occur at depths ranging from a few feet to $1 \mathrm{~km}$.

2. Subarea Assessment

\section{a. Ontario Subarea}

Nearly all of the Ontario subarea 1 ies within the bottomlands of the Malheur and Snake Rivers. With the exception of a small block of hill land in the northwest corner, this is all high-use agricultural, industrial or residential 1and. Ontario is the trading center of the study area, and probably 75 percent of the population is located in the Ontario subarea. Most of the area is covered with recent alluvium from the Malheur and Snake Rivers; underlying the alluvium are siltstones and claystones of the Chalk Butte Formation with a probable thickness of 1 to $1.5 \mathrm{~km}$. Structurally, the rocks dip at low angles, 3 to 4 degrees, toward the east. Studies based on information from oil and gas tests drilled around the region indicate that the Owyhee Basalt underlies the basin at a depth of about $2 \mathrm{~km}$ in the area of 0ntario. Where well control is available in western Idaho the depth to the Owyhee Basalt appears to be about the same. A major northeast-trending geologic structure, the Malheur River fault (Bowen and Blackwell, 1975), appears to parallel the Malheur River from Vale to Ontario.

A variety of geophysical data, including gravity data by Baldwin and $\mathrm{Hill}$ (1960) and Couch (1977), and an audio-magnetotelluric survey by Long, Hoover and Bramsoe (1975), confirm the stratigraphy, thickness and depth of rock units, and the general structural features. 
Figure 13.
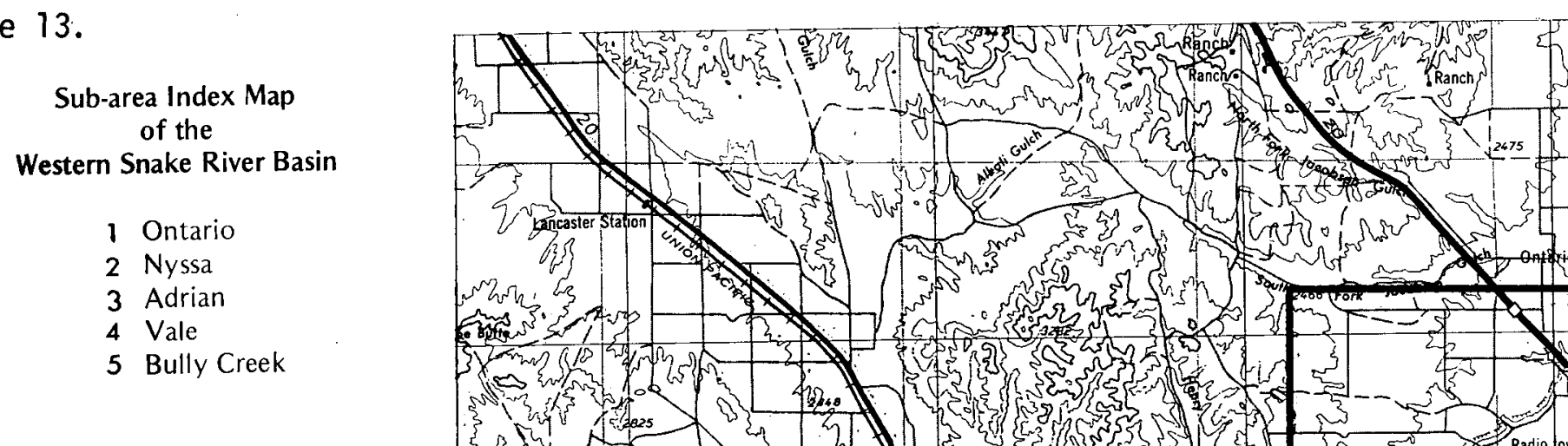

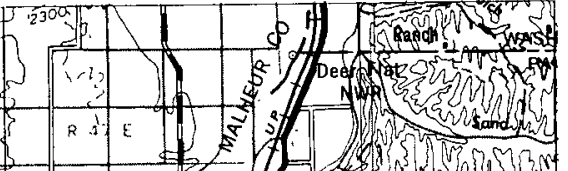
$243^{m}$ s.5

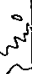
450 (5)

5. (1)

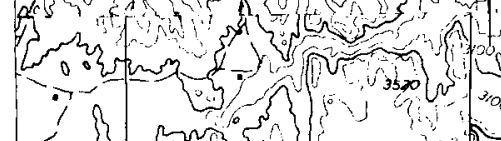
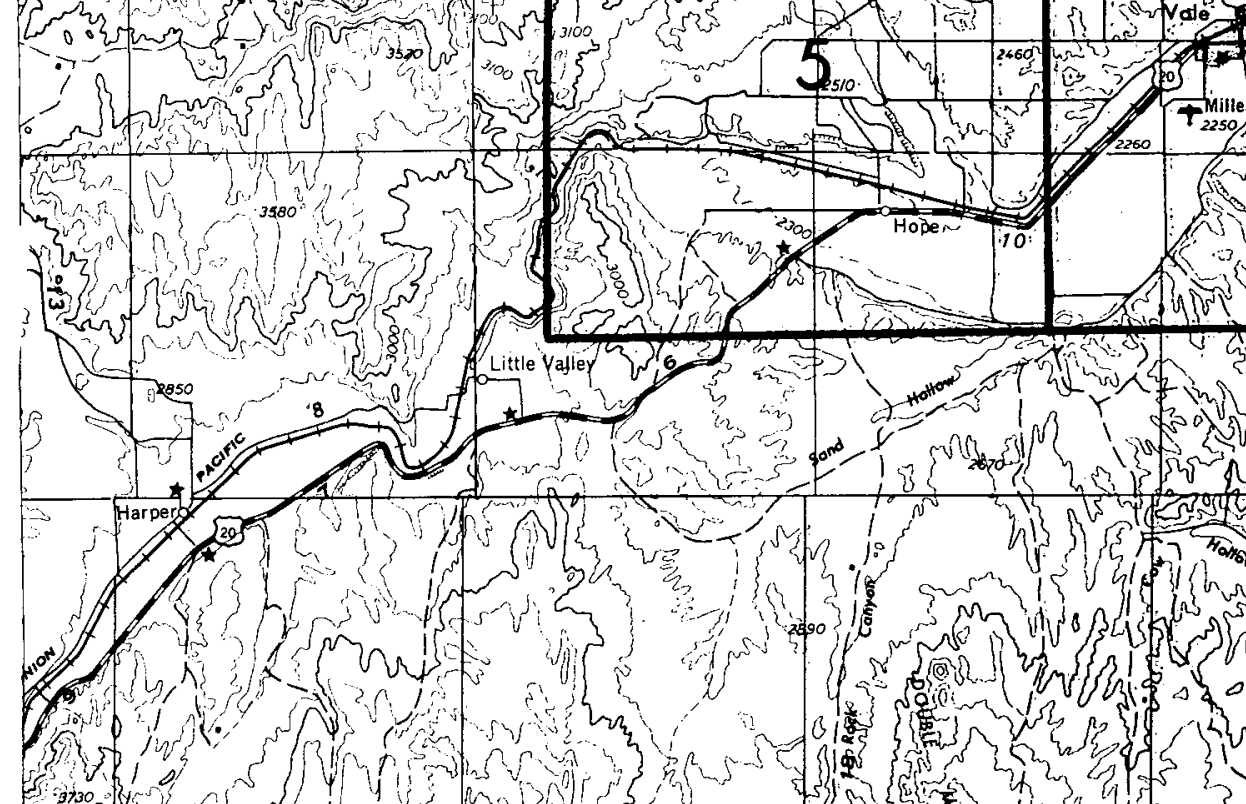

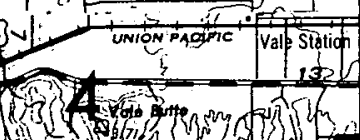

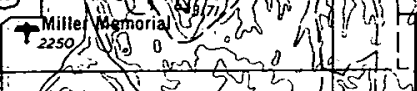
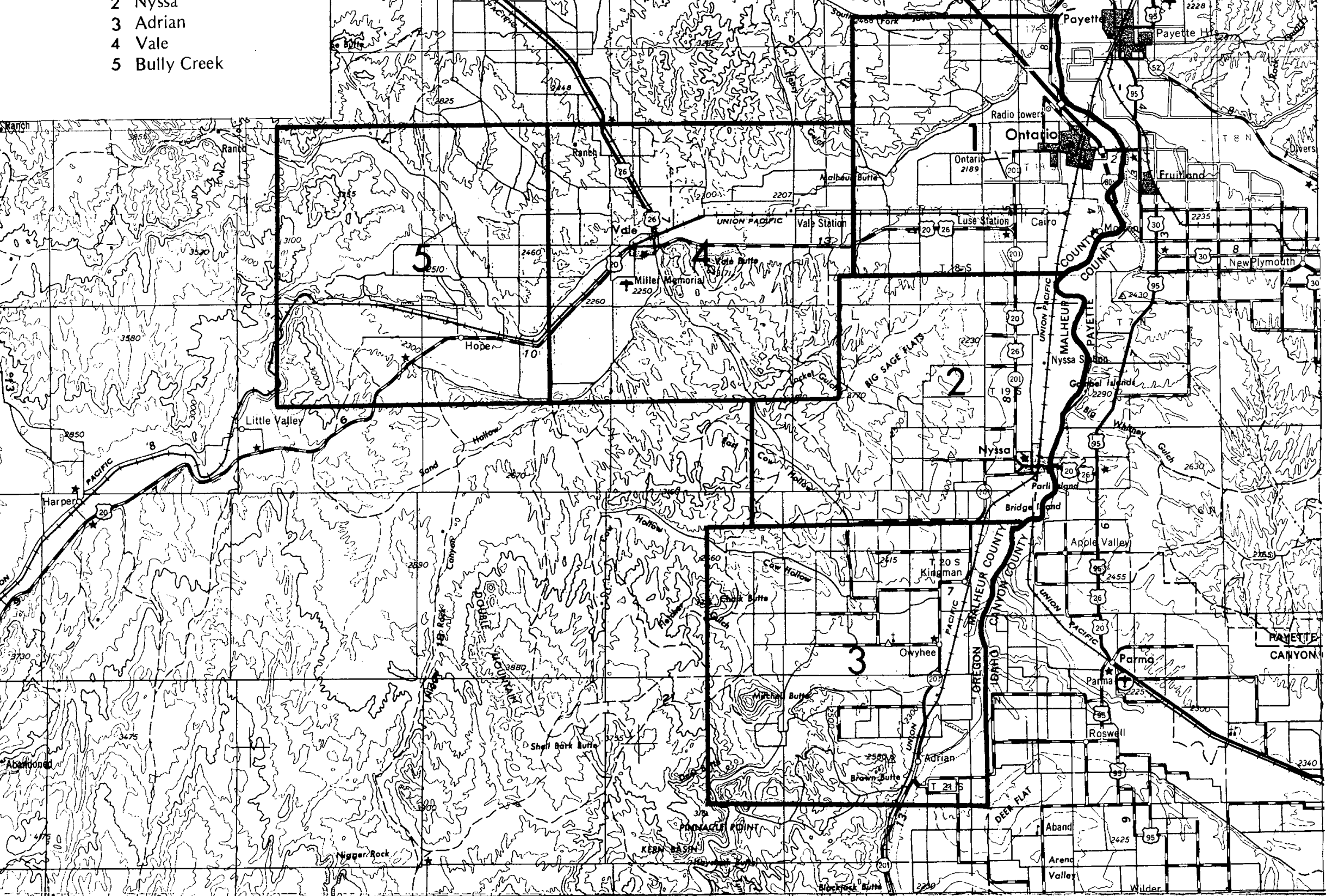


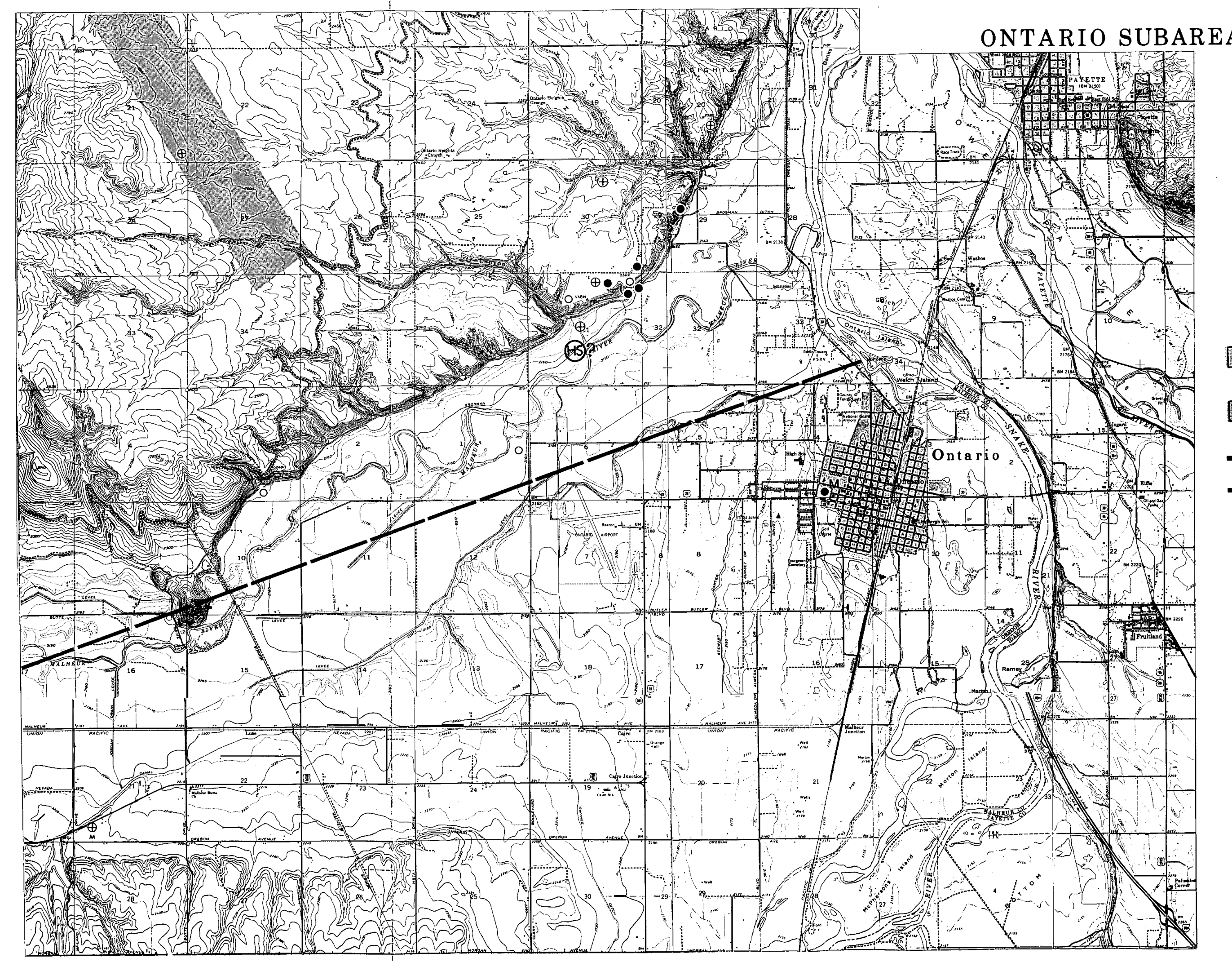

LEGEND

\begin{tabular}{|l} 
Greater than average potential for \\
hot 2 vater from rom $50 \mathrm{C}$ to $100^{\circ} \mathrm{C}$ at depths \\
of 500 to $1,000 \mathrm{~m}$.
\end{tabular} ot 500 to 1,0000 ni

Greater than average potential for
hot water from $50^{\circ} \mathrm{C}$ to $100^{\circ} \mathrm{C}$ at depths of 100 to $500 \mathrm{~m}$

$-\longrightarrow$

Fault inferred from geology. DRILL HOLE WITH GEOTHERMAL GRADIENT

- Gradient $<70^{\circ} \mathrm{C} / \mathrm{km}$.

- $\quad$ Gradient $\geq 70^{\circ} \mathrm{C} \leq 99^{\circ} \mathrm{C} / \mathrm{km}$.

( ) Gradient $\geq 100^{\circ} \mathrm{C} / \mathrm{km}$.

M Measured geothermal gradient.

(1)? $\begin{aligned} & \text { Hot spring or artesian warm water } \\ & \text { well: (?) not located during this } \\ & \text { study. }\end{aligned}$ 
The best evidence that geothermal resources underlie the Ontario subarea is the presence of high geothermal gradients measured around the margins of the area and from the fact that hot water is known to occur in the rocks that surround and underlie the basin.

Measured geothermal gradients from two wells drilled specifically for that purpose, one in sec. 16, T. $17 \mathrm{~S} ., \mathrm{R} .43 \mathrm{E}$. , and the other in Lions Park in Ontario, range from $86^{\circ}$ to $115^{\circ} \mathrm{C} / \mathrm{km}$.

The best potential for locating significant quantities of hot water in this subarea is to drill to the deep basalt aquifers as suggested earlier in the report. At Ontario the depth to the Grassy Mountain Basalt is predicted to be slightly over $1 \mathrm{~km}$ with temperatures of about $100^{\circ} \mathrm{C}$. The Owyhee Basalt should be found at about $2 \mathrm{~km}$ with a temperature of about $160^{\circ} \mathrm{C}$. The crosssection (Figure 11) illustrates subsurface geologic conditions in this region.

Waring (1965) reported a $73^{\circ} \mathrm{C}$ hot spring along the Malheur River three miles west of Ontario. A field check has failed to confirm this occurrence and local residents did not know of it.

No other surface indications are known to be present. The only shallow target zone is inferred from measured well gradients and here above-normal temperature may be found; water volume may not be adequate.

\section{b. Nyssa Subarea}

This subarea is largely in the flood plain of the Snake River except for the northwest quarter which is rolling sagebrushcovered hills (Figure 15). Like other bottomlands in the region, high-intensity agriculture is the predominate land use and perishable high-value crops such as sugar beets, onions, potatoes, corn and beets predominate. In the foothills dairying and cattle feeding are important industries. A fruit and vegetable cannery and a sugar mill are important processors of local crops and provide year-around employment in the region. The water for irrigation is supplied mainly from surface sources and delivered by ditches and pipelines. As surface water allocations are used up, groundwater is beginning to supply increasing amounts of irrigation water. Outside of the cities, most domestic water is from shallow wells.

Rocks underlying the subarea are fine-grained claystone, siltstone and sandstone of the Chalk Butte Formation. Terrace gravels cover the lower bench areas and fine-grained alluvium the flood plains of the Snake River. The cross-section (Figure 11) illustrates the general geologic environment of the region. Two $0 i 1$ well tests show that the Grassy Mountain Basalt occurs at a depth of about $1 \mathrm{~km}$ and the Owyhee Basalt at about $2 \mathrm{~km}$. 


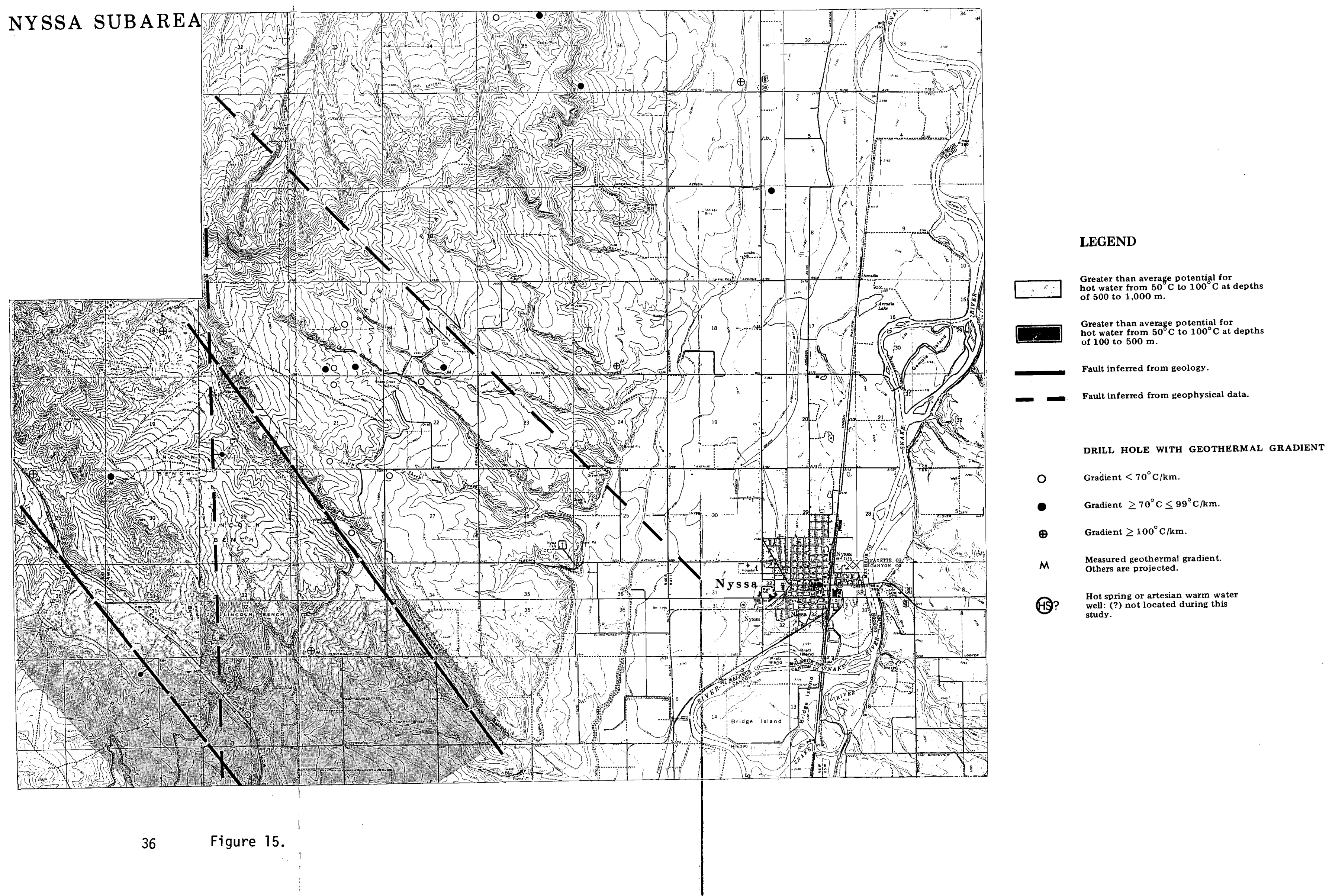


Geophysical studies by Couch (1977) and a geothermal study by Bowen and Blackwe11 (1975) show the subsurface structure of the Nyssa subarea to be complex and several north to northwesttrending faults both normal and strike slip have been delineated. Their inferred trends are shown in Fiqure 15.

There are no geothermal manifestations known in this subarea; however, temperature gradients, both measured and those interpreted from water well logs, show geothermal gradients greater than $100^{\circ} \mathrm{C}$ at several locations. The most prominent geothermal anomaly is the Cow Hollow geothermal anomaly as discussed by Bowen and Blackwell (1975), which extends into the southwestern edge of this subarea and is shown as a geothermal target zone on Figure 15.

Bowen and Blackwe1l (1975) have interpreted that this anomaly is caused by hot water or steam moving upward along the willow Creek fault zone and that drilling to depths of 1 or $2 \mathrm{~km}$ should locate high-temperature water or steam. There is also a possibility that high-temperature fluids might be located by drilling near the strike slip fault interpreted by Couch (1977) as some measured gradients and water well data show above-regional gradients along the fault zone. The potential reservoir horizons, the Grassy Mountain Basalt and the Owyhee Basalt are probably nearer the surface in the western part of the subarea so drilling there would not have to be as deep as in the eastern section. In the eastern part of the Nyssa subarea, it is expected that the same deep reservoirs discussed earlier are present, and at depths similar to those at Ontario.

\section{c. Adrian Subarea}

This subarea lies along the transition zone between the Snake River Plain and Owyhee Uplands (Figure 16). Along the eastern edge are the flat bottomlands of the Snake River. In the southwest corner the Owyhee River has eroded a canyon several hundred feet deep. After leaving the canyon the river meanders through a flood plain and joins the Snake River about $7 \mathrm{~km}$ north of Adrian.

Truck gardening takes place along the bottomlands of the Snake and Owyhee Rivers and the raising of hay, alfalfa and other grain crops in the adjacent foothills. In the upland areas cattle raising and dairying are the main land uses. Most of the population in the subarea is located near the eastern edge in Adrian and along State Highway 201 which leads north to Nyssa and Ontario. Farms are present throughout all of the region except in the higher hills in the southwest corner. Surface water provides most of the irrigation water while shallow wells provide most domestic water. 
ADRIAN SUBAREA

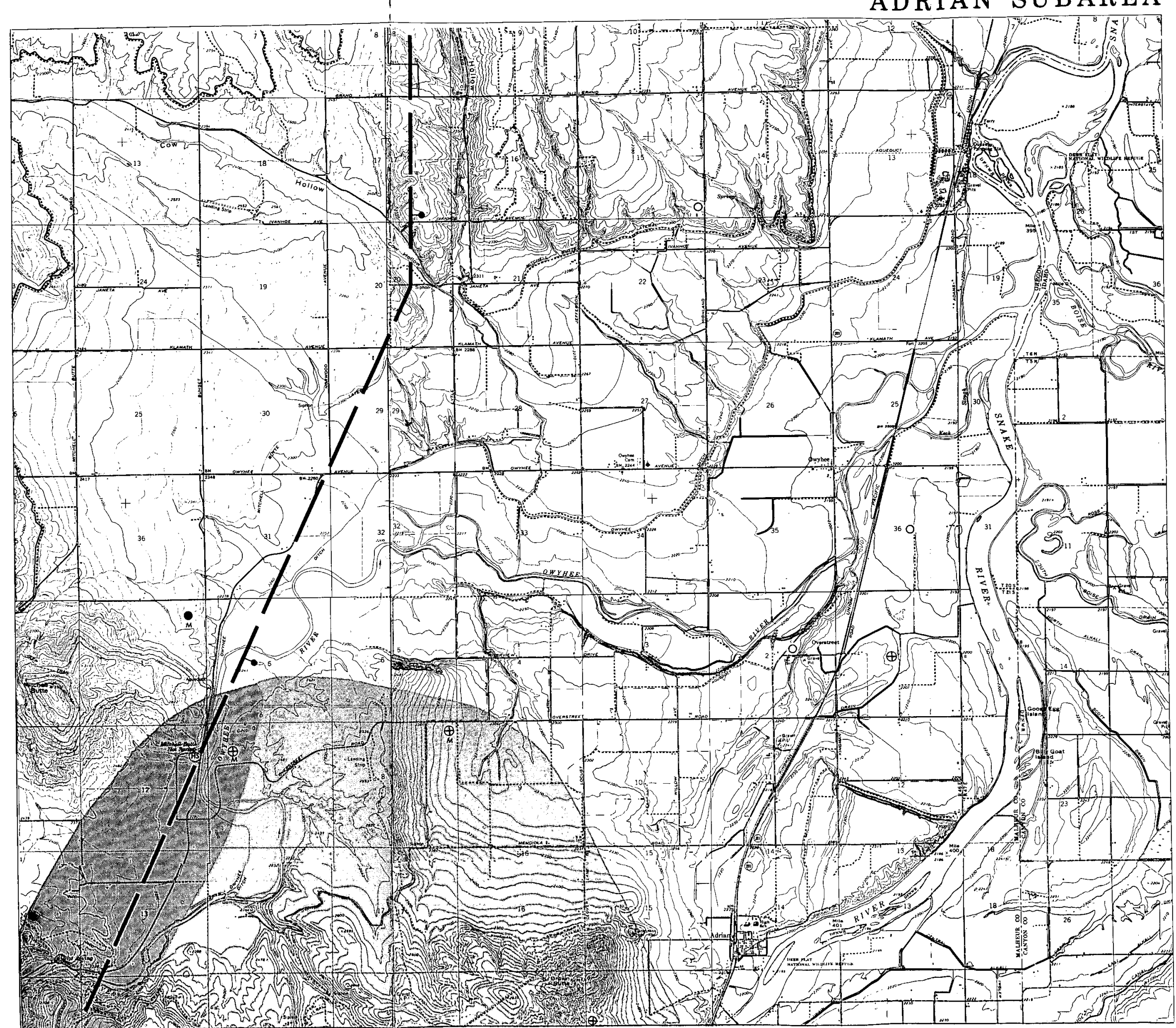

Figure 16.
LEGEND

Greater than average potential for
hot wather from $50 \mathrm{C}$ to $100 \mathrm{C}$ Cat depths
of 500 to $1,000 \mathrm{~m}$. of 500 to $1,000 \mathrm{~m}$.

Greater than average potential for
hot water from $50^{\circ} \mathrm{C}$ to $100^{\circ} \mathrm{C}$ at depths

Fault inferred from geology.

DRILL HOLE WITH GEOTHERMAL GRADIENT

- Gradient $<70^{\circ} \mathrm{C} / \mathrm{km}$

- Gradient $\geq 70^{\circ} \mathrm{C} \leq 99^{\circ} \mathrm{C} / \mathrm{km}$.

$\oplus \quad$ Gradient $\geq 100^{\circ} \mathrm{C} / \mathrm{km}$.

M M Measured geothermal gradient.

(1)ㅇ? 
Surficiat rocks are the fine-grained lacustrine and fluviatile. sedimentary rocks of the Chalk Butte Formation. Corcoran (1962) reports that the Chalk Butte rocks here lie directly on the Owyhee Basalt and that the Grassy. Mountain Basalt, Kern Basin Formation and the Deer Butte Formation were either eroded away or were not deposited. Corcoran (1962) shows a fault just to the south of the subarea aligned with the Owyhee Canyon. Couch (1977) on geophysical evidence extends this fault northeasterly through the area. Within the Owyhee Canyon at least four hot springs are known to be associated with this fault. Figure 16 shows this faulting and the location of Mitchell Butte Hot Springs and Deer Butte Hot Springs.

The presence of the two hot springs mentioned above along with several more along this same trend in the Owyhee Basalt to the southwest suggests the presence of a major thermal zone. Two measured wells, one near the mouth of the Owyhee Canyon (sec. 7, T. 21 S., R. 46. E.) and the other $2 \mathrm{~km}$ to the east (sec. 8, T. 21 S., R. 46 E.), both give gradients of around $120^{\circ} \mathrm{C} / \mathrm{km}$, and broaden the geothermal target zone. Drilling to depths of 100 to $500 \mathrm{~m}$ adjacent to the plotted fault should locate hot water in a temperature range of $50^{\circ}$ to $100^{\circ} \mathrm{C}$. Between the Owyhee Canyon and Adrian, as shown on Figure 16, drilling to a depth of $500 \mathrm{~m}$ to $1 \mathrm{~km}$ has a good chance of locating hot water between $50^{\circ}$ and $100^{\circ} \mathrm{C}$.

\section{d. Vale Subarea:}

This subarea. (Figure 17) is made up mostly of rolling foothills of the Owyhee Upiands. that form the western and southern boundary of the Western. Snake River Basin: The Malheur River, one of the principal tributaries of the Snake, has cut a valley one to three miles wide and in places two to three benches or terraces have been formed by this erosion. Willow Creek, a tributary to the Malheur. River, has. also eroded a flat valley two to three miles wide and enters the Malheur Valley at Vale.

Farming activities and all of the homes are located within these two valleys and a few of their small tributaries. The uplands, consisting of rounded hills, are used for grazing. Land ownership patterns follow the topography, with nearly all of the valley land and near foothills under private ownership and the higher hilly land in federal ownership. The long arowing season, nearness to processing plants and relatively abundant water had encouraged the development of large-scale farming within the valleys. Most of the water used for irrigation comes from ditches from nearby surface storage reservoirs. With few exceptions groundwater for irrigation is limited to shallow gravel zones near existing streams. Lesser amounts of groundwater for stock watering can sometimes be located in perched lenses at relatively shallow depths in the foothills. 
VALE SUBAREA

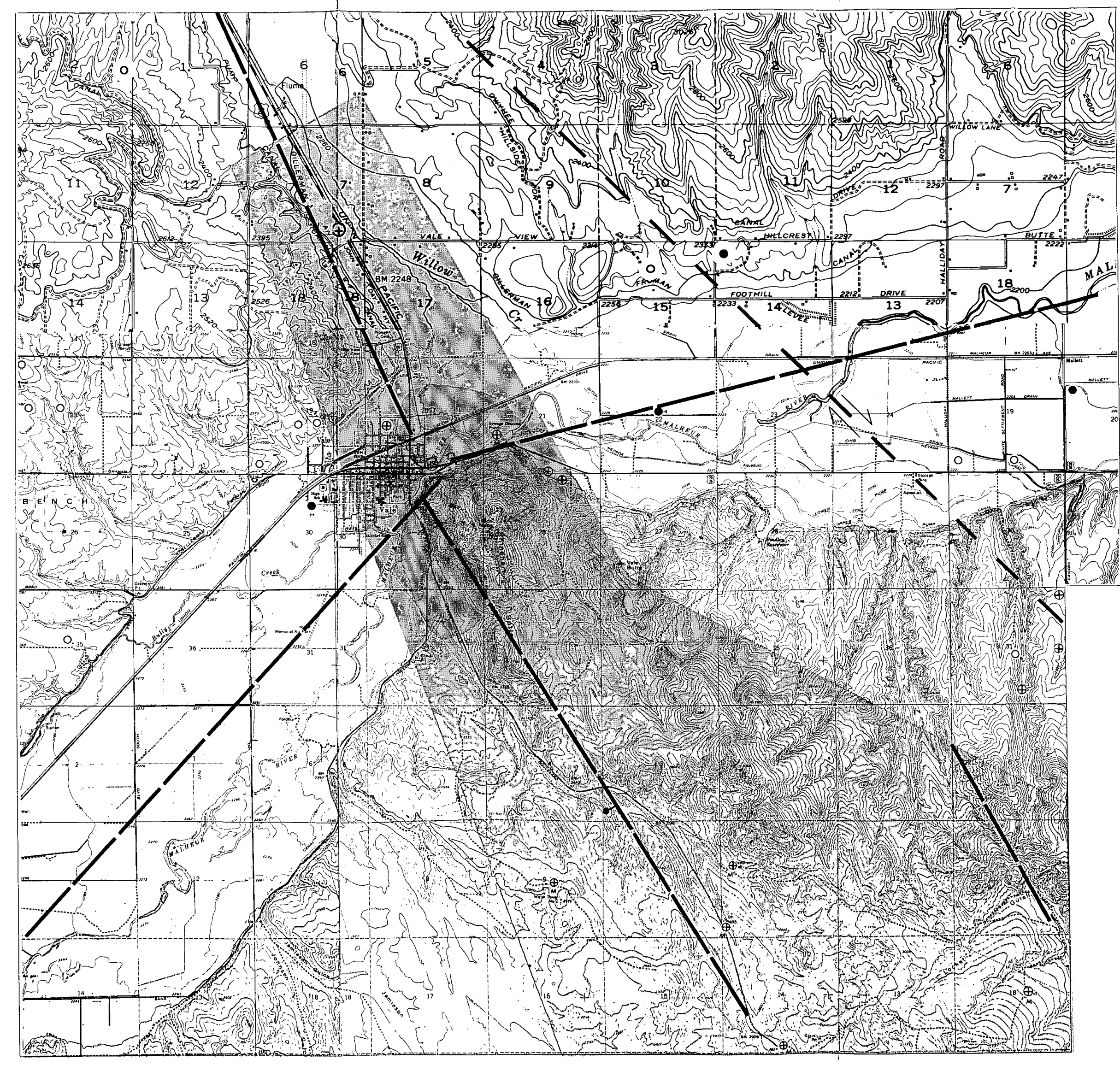

LEGEND

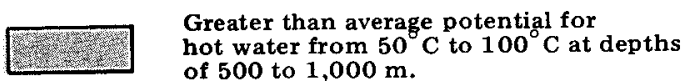

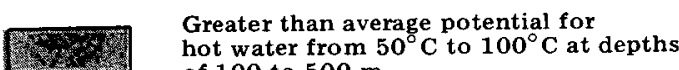

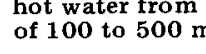

Fault inferred from seologr.

- Fault inferred from geophysical data.

DRILL HOLE WITH GEOTHERMAL GRADIENT

- Gradient $<70^{\circ} \mathrm{C} / \mathrm{km}$.

- $\quad$ Gradient $\geq 70^{\circ} \mathrm{C} \leq 99^{\circ} \mathrm{C} / \mathrm{km}$

$\oplus \quad$ Gradient $\geq 100^{\circ} \mathrm{C} / \mathrm{km}$.

M M Measured geothermal gradient.

(16)? $\begin{aligned} & \text { Hot spring or artesian warm water } \\ & \text { well: (?) not located during this } \\ & \text { study. }\end{aligned}$ 
Rocks exposed in the foothills are, with the exception of a few alluvial terraces, entirely of the Chalk Butte Formation and consist mainly of siltstone, with lenses of impure volcanicderived sandstone and conglomerate. Within the valleys finegrained alluvium predominates, but occasional gravel layers are reported in the well logs.

Along the south side of the Malheur River the rocks generally dip 2 to 4 degrees toward the east, into the Snake River Basin. Several small and a few major faults can be seen and adjacent to them; dips are often quite steep. These fault zones and steeply dipping beds can best be seen at Rhinehart Buttes and vale Butte south and east of vale. The Willow Creek fault zone (Bowen and Blackwel1, 1975), also called the Vale fault zone by Lawrence (1976), runs diagonally from northwest to southeast through the subarea. The zone is interpreted by Bowen and Blackwell (1975) to be a normal fault with the west side down relative to the east. Lawrence (1976) believes it to be a right lateral strike slip fault with the northeast side being displaced toward the southeast. A subparallel fault 5 to $6.5 \mathrm{~km}$ northeast of the Willow Creek fault is reported by Couch (1977), based primarily on the interpretation of a gravity survey of the region. Topography and other field evidence supports the presence of this fault. From the gravity study of Couch it appears this fault is down to the east, producing an upraised block or "horst", referred to as the Vale horst in this report. The Malheur River fault, a major northeast-southwest-trending cross fault generally following the course of the Malheur River, has been reported by Bowen and Blackwell (1975).

A part of the area included as the Vale subarea has been designated as a Known Geothermal Resource Area (KGRA) by the U.S. Geological Survey and geothermal leases on the federal lands within the block are offered for sale by competitive bidding. A total of 8,393 acres of the federal leases have been granted at prices ranging between $\$ 3$ and $\$ 16.16$ per acre. Geotherma1 leases have also been negotiated for much of the private 1 and.

Vale Hot Springs, located on the east edge of the city of Vale, has a surface temperature of $97^{\circ} \mathrm{C}$ and a visible flow of 25 to 50 gallons per minute. Chemical analys is on the hot spring waters shows it has dissolved solids of $882 \mathrm{ppm}$. The alkali ratio indicates a minimum estimated reservoir temperature of $157^{\circ} \mathrm{C}$ (Mariner and others, 1975). A shallow well drilled $50 \mathrm{~m}$ east of the hot springs was reported to have temperatures of $110^{\circ} \mathrm{C}$ (Ross Butler, oral communication, 1976). Other shallow wells with temperatures slightly over boiling are located within a half mile of the hot springs, all on the south side of the Malheur River. On the north side of the river near Vale, just to the north of Rhinehart Buttes, shallow wells do not intersect the high-temperature zone located just south of the river, but a $320-\mathrm{m}$ 0il test in the SW $1 / 4$ of sec. $21, T .18 \mathrm{~S} .$, R. $45 \mathrm{E}$. shows there is also a high geothermal gradient of $147^{\circ} \mathrm{C} / \mathrm{km}$ on the north side of the river. Warm-water 
wells and the high geothermal gradients along the Willow Creek fault zone, the west boundary of the Vale horst, indicate rising thermal waters to the southeast of Vale. There has been very little drilling on the east edge of the vale horst, but three water wells in sec. $31, T .18 \mathrm{~S} .$, R. $46 \mathrm{E}$., have projected geothermal gradients of more than $100^{\circ} \mathrm{C} / \mathrm{km}$. Northwest of Vale along Willow Creek a few scattered wells with geothermal gradients in the range of $90^{\circ}$ to $110^{\circ} \mathrm{C} / \mathrm{km}$ may also indicate rising thermal waters.

Geothermal waters ranging from near to slightly above boiling in temperature can be expected in shallow wells (100 to $300 \mathrm{~m}$ ) along the south and east side of the Malheur River extending possibly 1 to $3 \mathrm{~km}$ from Vale. North of the Malheur River and north of Highway 26 the geothermal gradient of $147^{\circ} \mathrm{C} / \mathrm{km}$ in $\mathrm{sec} .21, \mathrm{~T} .18 \mathrm{~S}$, R. $45 \mathrm{E}$. and $122^{\circ} \mathrm{C} / \mathrm{km}$ in sec. $20, \mathrm{~T} .18 \mathrm{~S} ., \mathrm{R} .45 \mathrm{E}$. indicate a geothermal reservoir, but deeper than that south of the river.

Along Lytle Boulevard, southeast of Vale, a zone of high heat flow, the Cow Hollow anomaly, was reported by Bowen and Blackwell (1975). From their work and from the structural picture out 1 ined by the geophysical studies of Couch (1977), it appears that the Grassy Mountain Basalt may be at depths as shallow as 400 to $500 \mathrm{~m}$ along the vale horst. The high geothermal gradient along Lytle Boulevard indicates that water near boiling in temperature could be found in the Grassy Mountain Basalt at those depths. In the Owyhee Basalt at depths of 1500 to $2000 \mathrm{~m}$ temperatures could be in the range of $140^{\circ}$ to $165^{\circ} \mathrm{C}$.

A slightly more speculative hot-water zone is marked to the northwest of Vale, along the Willow Creek fault zone because of the presence of the scattered water wells indicating geothermal gradients of $90^{\circ}$ to $110^{\circ} \mathrm{C} / \mathrm{km}$.

\section{e. Bully Creek Subarea}

This subarea (Figure 18) is located in the foothills of the Owyhee Uplands; the Malheur River has excavated a flat valley about $3 \mathrm{~km}$ wide through the middle of the area and Bully Creek, following a valley about 1-1/2 km wide, flows in from the northwest. Along the north side of the Malheur River is a broad gravel covered bench with Bully Creek Valley dividing it into what is known as East Bench and west Bench. Farming takes place in the valley and in the Bench area and grazing in the rest of the hills. Most of the irrigation water is provided by surface canals that use water from the Malheur River and from Bully Creek Reservoir. A few wells are drilled into the Malheur River and Bully Creek floodplains to provide some irrigation water. In the East and West Bench areas there is sufficient water for domestic wells in the gravel terraces. Away from the valleys a few stock wells produce sma 11 amounts of water from perched zones. 
BULLY CREEK SUBAREA

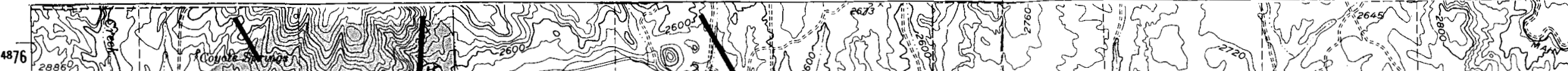
0 .

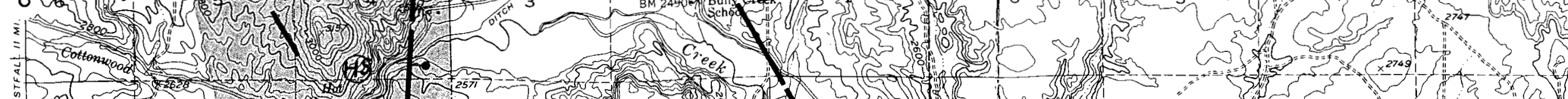

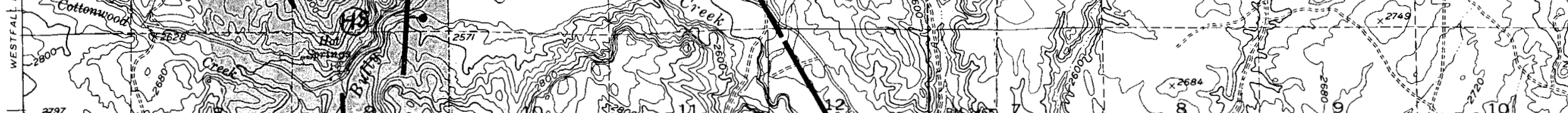
474

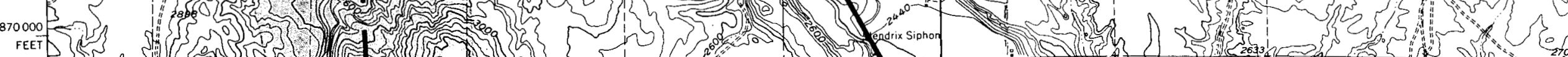
18 (13) (18)

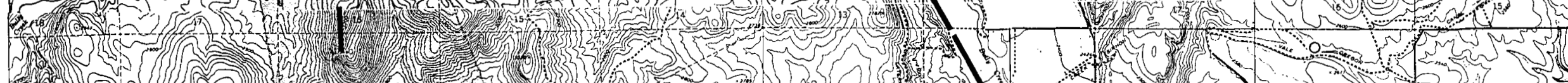

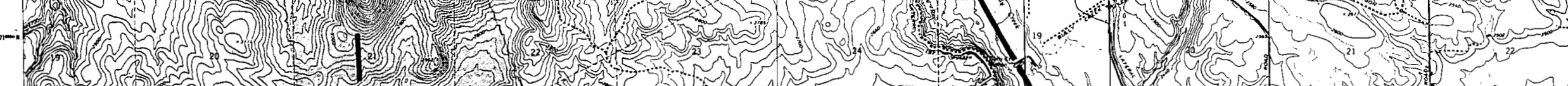
2. N - (2) (c)
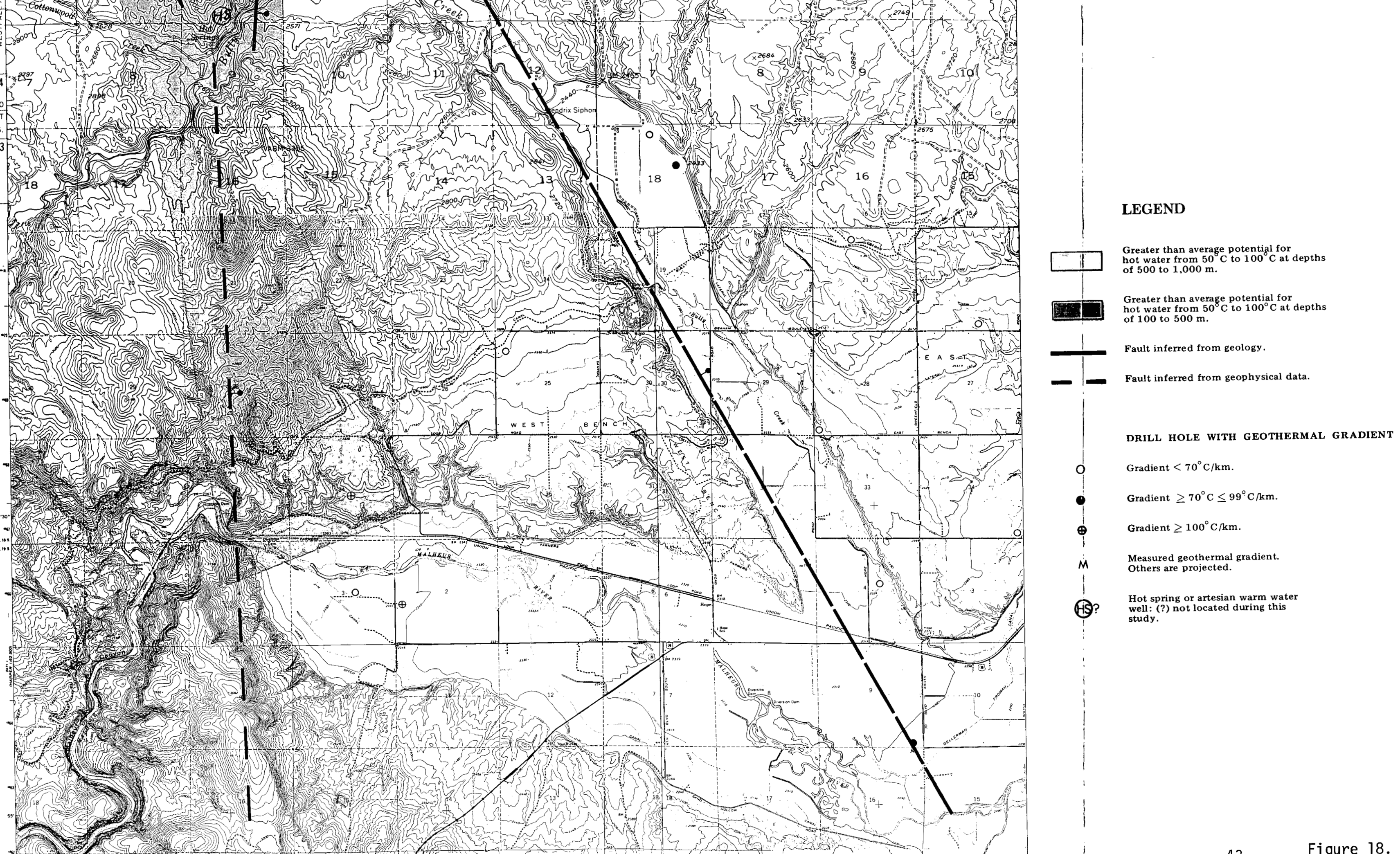
Land ownership patterns follow traditional eastern Oregon usage with the river valleys and the bench lands near the main streams in private ownership. Large farms make up most of the flat valleys while smaller farms and dairies are in the bench areas and lower foothills. The uplands are mainly in federal ownership and are largely used for grazing.

Surficial rocks are largely unconsolidated to semiconsolidated sediments of the Chalk Butte Formation. Near the northwest corner of the area are basalts reported to be of late Miocene age by Walker (1977), correlating with the Owyhee and the Columbia River Basalts. Just south of the subarea, Grassy Mountain Basalt is exposed in Double Mountain. Quaternary terrace gravels cover both the East and West Bench.

This subarea is on the western edge of the Western Snake River Basin; the older Miocene basalts occur immediately to the west and the younger basin sediments dip and thicken toward the east. $0 i 1$ tests and some of the water wells drilled in the area intersect basalts at relatively shallow depths. Two prominent fault zones intersect in the area; one, a northwest-southeast zone follows the course of Bully Creek; another following a northeastsouthwest trend aligns with Sand Hollow and the Malheur River. The structural interpretation by Bowen and Blackwell (1975) indicates the presence of a graben, or down-dropped block between the Bully Creek and Willow Creek fault zones. Couch (1977), from the interpretation of geophysical data, also reports a graben in the area between Vale and Bully Creek, but his data indicates the graben to be west of the Bowen and Blackwell projection.

Geothermal manifestations in the subarea are Neal (Bully Creek) Hot Springs in the NW $1 / 4$ of sec. 9, T. 18 S., R. 43 E., and an unnamed warm spring about one mile to the northeast of Neal Hot Springs. Neal Hot springs has a maximum surface temperature of $87^{\circ} \mathrm{C}$ and water analyses indicate that minimum subsurface reservoir temperatures are $173^{\circ}$ to $181^{\circ} \mathrm{C}$ (Mariner and others, 1974). Two water wells on the east edge of the subarea show above-normal gradients. The Nelson well in sec. $34, T .18 \mathrm{~S} ., \mathrm{R} .43 \mathrm{E}$. has a reported water temperature of $21^{\circ} \mathrm{C}$ at a depth of $58 \mathrm{~m}$, which ind icates a geothermal gradient of $157^{\circ} \mathrm{C} / \mathrm{km}$. The $\mathrm{BLM}$ Vines $\mathrm{Hi} 11$ well in sec. 22, T. $19 \mathrm{~S} ., \mathrm{R} .43 \mathrm{E}$, has a water temperature of $31^{\circ} \mathrm{C}$ from a $219-\mathrm{m}$ depth, indicating a gradient of $94^{\circ} \mathrm{C} / \mathrm{km}$.

A prospective drilling target is shown on Figure 18 along the western edge of the subarea. The Owyhee Basalt appears very close to the surface, probably covered only by a thin layer ( 0 to $1000 \mathrm{~m}$ ) of Chalk Butte Formation. The high temperatures indicated by the geochemical analysis (Mariner, 1974) for Neal Hot Springs may give an indication of reservoir conditions. A fault zone postulated by Couch (1977) from geophysical data appears to be the zone of leakage of the geothermal fluids. From the present indications further drilling along this zone appears to be warranted. 


\section{Reservoir Management}

To conserve and to achieve the greatest beneficial use of geothermal resources and to protect the groundwater from damage due to excessive reservoir drawdown or improper disposal of the spent geothermal fluids, a program of reservoir management should be established at the time of initial reservoir development. Calculations indicate that large quantities of energy underlie the study areas (White and Williams, 1975); however, to transfer this energy to the surface requires large flows of water.

It is possible that the geothermal, reservoirs in the study areas contain enough water to maintain production for as long as they are needed or that they will be recharged by natural means. Initial flow testing can only indicate the rate at which the well can be produced, not the life of the well or the ultimate reservoir capacity, nor if recharge exists. To determine if a reservoir has sufficient capacity to fulfill the needs of a major industrial or institutional user could require many years of production and long-term testing and monitoring. This uncertainty of availability of water, and of its possible effects on the shallower groundwater in the areas can be resolved if the spent geothermal fluid is returned to the production reservoir. Additionally, this method of disposal eliminates contamination of surface waters that might result if surface disposal methods are used.

Any significant use of geothermal energy in the Western Snake River Basin or an increase in its use in the Klamath Basin will require large flows of water. For example, if a modest-sized industrial plant presentiy using natural gas in amounts of 10,000 therms a month in a process that requires maximum temperatures near $150^{\circ} \mathrm{C}$ switches to geothermal energy, it will require a pass-through of water amounting to $23 \mathrm{gpm}$ or approximately 3 acrefeet per month or 36 acre-feet a year. The present pass-through at oregon Institute of Technology where a 500,000 square foot campus is heated with geothermal water is 200 to 250 acre-feet per year. Therefore, it can be seen that a significant increase in the usage of geothermal heating could increase demand for water by several thousand acre-feet per year in each region. The disposal of this flow into surface drainages could present both disposal and environmental problems and an increase in the demand on the groundwater of that magnitude might cause objectional reservoir drawdown. With proper reservoir management the potential problems of handling these large flows can be taken care of by returning the geothermal fluid to the reservoir via return wells.

Fortunately, in $\mathrm{Klamath}$ Falls experience in returning large flows of geothermal water has been developed over the 1 ast 15 years by the Klamath Falls School District. Three schools use geothermal heating systems in which the hot water is circulated through heat exchangers in the buildings then returned to the reservoir via return wells. These three systems which have been in operation since 1962, 1965 and 1967 have returned an average of 1,000 acre-feet of water a year into the reservoirs with no apparent deleterious effects. 
In other geothermal fields in both the United States and abroad routine methods of return of the fluids into the reservoirs have been practiced, for several years in some cases, and in others lonq-term production tests have shown this method of disposal to be satisfactory. Reports on several of these return systems have been presented in the 1 iterature and are summarized here.

In Rotorua, New Zealand, Burrows (1970) and Shannon (1975), have reported on the systems developed in that area. In Rotorua the geothermal waters are generally quite high in temperature, $105^{\circ}$ to $170^{\circ} \mathrm{C}$, and have wellhead pressures ranging up to 150 psig. Burrows (1970) reports that there are over 700 production wells within the city and that a return well, termed a "soak bore" is normally drilled for each production well and that it is routine practice to drill the "soak bore" on the same lot as the production we11. Many of these "soak bores" are shallow, hand-dug pits, lined with rock and covered with wooden or concrete doors that allow the water to soak into the permeable pumiceous soil under the city. Others are deep wells that return the spent fluids to the reservoir, most often below the production zone. In Rotorua a position of Inspector of Geothermal Works has been established to encourage and oversee the orderly and efficient development of the geothermal resources. Additionally the city requires that all geothermal wastewaters be properly returned to the ground so it has become standard practice to drill the production and the disposal wells at the same time and on the same property. The geothermal waters in Rotorua normally contain 1,800 to $2,000 \mathrm{ppm}$ dissolved solids with 180 to $200 \mathrm{ppm}$ silica. The routine return of geothermal fluids into the ground has been practiced in Rotorua for many years and both authors report it has no detrimental effects in the region.

In 0take, Japan, a high-temperature geothermal field in which the fluid is used for the production of electric power, return of the water began in 1970. Reports by Yanagase, Suginohara, and Yangase (1970) and Kubota and Aosaki (1975) detail the experience in that field. In the Otake case several production wells produce an average of 2,300 gallons per minute, or over a year's time nearly 3,700 acre-feet of water. Since 1972 this has all been returned into the production reservoir via three return wells. Prior to 1970 the wastewater from 0take field was piped to a hydroelectric reservoir $4.5 \mathrm{~km}$ from the field for disposal. This method started causing problems immediately as the large amount of silica in the waters, in this case 400 to $600 \mathrm{ppm}$ with 3,000 to $4,000 \mathrm{ppm}$ total dissolved solids, tended to precipitate and plug the pipeline making it necessary to frequently clean the pipeline by mechanical scrapers. Because of the continual problem in maintaining the pipelines it was decided to experiment with returning the fluid directly into the reservoir. After successfully running a two-year test from 1970 to 1972 in which a part of the fluids was returned to an unused we 11 in the center of the field, two disposal wells were drilled and the pipeline disposal system abandoned. Kubota and Aosaki (1975) report that with the use of the pipeline disposal system there was a steady decline in the production of the field with power output declining from 11 to 8.7 MW from 1967 to 1971 . 
With the beginning of fluid return to the reservoir the decline stopped in 1971 and production began to increase, rising to $10 \mathrm{MW}$ by 1973. At the time of the report (1975), production had held level since 1973 at $10 \mathrm{MW}$. The decline was caused by natural recharge being unable to supply the water necessary to maintain constant production; return of the water to the reservoir brought in sufficient amounts to recover most of the lost production.

Several other geothermal return systems are described in the literature including The Geysers by Chasteen (1975), the Imperial Valley by Chasteen (1975) and by Mathias (1975), Ahuachapan, El Salvador by Siqvaldson and Cuellar (1970 and Einarsson, Vides and Cuellar (1975). A more detailed review of these systems is presented in the appendix.

Initial planning of a geothermal development should involve, after discovery of the resource, the drilling of sufficient return wells to allow for the disposal of all the excess geothermal fluid. Theoretical studies to date indicate that returning the spent fluid to below the production zone would allow it to regain its original heat (Bodvarsson, 1972). In practice at $\mathrm{Kl}$ amath $\mathrm{Falls}$, The Geysers, and at 0take, return wells have been located both at field margins and within the center of the field, and apparently at random depths into the reservoir, with no detrimental effect. It appears to be important to avoid direct short-circuiting of the returned water into production flow. A program of production and return testing levels that give minimum interference could be worked out.

In summary, research of the geothermal 1iterature shows that nearly all geothermal return systems have been successful, in some cases increasing production rates. The most common problem has been the precipitation of excess silica when the geothermal waters have been allowed to cool. At Klamath Falls and in the Snake River Basin, analyses show silica to be low enough so it should not be a problem. Various problems with the injection systems arose in several cases, but through study and enqineering, successful systems were developed in nearly all cases. The example of the three return systems utilized by the Klamath Falls School District is probably typical of conditions and results that can be expected from return systems for future K1amath Basin geothermal wells, and for those in the Western Snake River Basin.

\section{E. Drilling and Transmission Costs}

Drilling costs vary widely dependent largely on three factors: 1) drill rig availability; 2) depth of hole; and 3) types of rocks encountered. Under normal conditions there are manv contract. water we 1 ! drill lers with equipment capable of drilling 6-inch to 12 -inch holes to depths of 1,500 to 2,000 feet. Very few drillers in the Western Snake River Bas in are capable of drilling to depths of 2,000 to 3,900 feet, but equipment may be brought in from central Idaho or western Oregon where drillers have greater capability. For drilling to depths greater than 3,900 feet, larger $0 i 1$ field drill rigs will have to be brought in from out-of-state, probably Utah, Montana, Wyoming or California. 
Closely related to drill rig availability is the number of holes to be drilled on any project. If only one hole is drilled all mobilization and demobilization cost must be charged against that one hole, while on a multi-well program these charges can be spread over several wells. Costs might also be brought down by drilling "slim hole" exploration holes.

These holes are generally six inches or less in diameter and are capable of locating a reservoir, but would probably not be satisfactory for production testing nor for a production well.

\section{Western Snake River Basin}

Drilling costs are estimated for the three ranges of depths: to 1,300 feet; 1,300 to 3,900 feet; and 3,900 to 8,200 feet based on conversations with drillers and from experience in other regions.

Exploration holes cased from $1 / 3$ to $1 / 2$ the total depth:

$\begin{array}{ll}\text { to } 1,300 \text { feet } & \$ 5 \text { to } \$ 1.5 / \mathrm{ft} \\ 1,300 \text { to } 3,900 \text { feet } & \$ 14 \text { to } \$ 31 / \mathrm{ft} \\ 3,900 \text { to } 8,200 \text { feet } & \$ 20 \text { to } \$ 50 / \mathrm{ft}\end{array}$

Production wel1s, cased, but not including pumps:

$\begin{array}{ll}\text { to } 1,300 \text { feet } & \$ 11 \text { to } \$ 31 / \mathrm{ft} \\ 1,300 \text { to } 3,900 \text { feet } & \$ 21 \text { to } \$ 50 / \mathrm{ft} \\ 3,900 \text { to } 8,300 \text { feet } & \$ 31 \text { to } \$ 61 / \mathrm{ft}\end{array}$

The above costs are relatively low in comparison to drilling costs in other parts of the state. This reflects the fact that there have been many $0 i 1$ and gas exploration tests drilled in or near the study area. Newton and Corcoran, 1963, report that a total of 44 exploration tests were drilled in the Western Snake River Basin from 1910 to 1961. These test wells have shown that within the study area the dominantly sedimentary rocks make drilling relatively simple. In other parts of the state where geothermal resources, could be expected such as the Klamath Basin or the Cascade Mountains, most of the rocks are volcanic. This in general makes more difficult drilling conditions, especially if the volcanics are highly fractured.

Using the above figures, and considering the drilling conditions in the Western Snake River Basin, the following drilling cost scenarios are estimated:

1,300-foot production test north of Vale

Well program: $10^{\prime \prime}$ to $160^{\prime}$, setting $8^{\prime \prime}$ casing, $6^{\prime \prime}$ casing to 1,300 feet

Mobilization and demobilization

Drilling a $\$ 6 / \mathrm{ft}$

Casing $\mathbb{a} \$ 6 / \mathrm{ft}$

Contingencies a $30 \%$

TOTAL
$\$ 2,000$

8,000

$\$ \frac{8,000}{\$ 18,000}$

5,400

$\$ 23,400 \approx \$ 20 / \mathrm{ft}$ 
3,900-foot production test, Ontario

Well program: $10^{\prime \prime}$ to $160^{\prime}$, setting $8^{\prime \prime}$ casing, 6" casing to tota 1 depth

Mobilization and demobilization

Drilling o $\$ 12 / \mathrm{ft}$

Casing a $\$ 8 / \mathrm{ft}$

Contingencies a $30 \%$

$\$ 10,000$

48,000

30,000

$\$ 88,000$

TOTAL

26,400

$\$ 114,400 \approx \$ 30 / \mathrm{ft}$

8,200-foot production test, Ontario

Well program: $16^{\prime \prime}$ to $160^{\prime}$, setting $12^{\prime \prime}$ casing, $8^{\prime \prime}$ casing to 3,300 feet, $6 "$ casing to 8,200 feet

Mobilization and demobilization

Drilling o $\$ 31 / \mathrm{ft}$

Casing o $\$ 11 / \mathrm{ft}$

Contingencies o $30 \%$

$\$ 100,000$

250,000

87,500

$\$ 437,500$

131,250

TOTAL

$\$ 568,750 \approx \$ 70 / \mathrm{ft}$

2. Drilling Costs--Klamath Basin

Well drilling costs in the $\mathrm{Klamath}$ Basin by cable or rotary rigs up to 3,000 feet is as follows:

$\$ 1$ per inch of diameter per foot of depth in "soft" rock and $\$ 2.50$ per inch of diameter per foot of depth in "hard" rock up to 500 feet in depth. For every additional 500 feet increment add $\$ 1$ per foot of depth.

Casing cost can be estimated at $\$ 1$ per inch of diameter per foot of depth. Full-depth casing is assumed for all wells.

Using the above costs which include mobilization and demobilization and considering drilling conditions in the $\mathrm{Klamath} B$ asin (i.e., onethird of drilling in "hard" rock), the following drilling cost scenarios are developed: 
We11 program: 12" diameter hole with. 10" casing to 500 feet, 10" hole with 8" casing to 2,000 feet, and 8" hole with $6^{\prime \prime}$ casing to 3,000 feet

\section{Average Well Costs}

Depth (feet)

Drilling costs (\$)

Casing cost $(\$)$

Total cost $(\$)$

$\begin{array}{rrrrr}100 & 500 & 1,000 & 2,000 & 3,000 \\ 1,800 & 9,000 & 17,000 & 34,5,00 & 51,000 \\ 1,000 & 5,000 & 9,000 & 17,000 & 23,000 \\ 2,800 & 14,000 & 26,000 & 51,500 & 74,000\end{array}$

\section{Range of Costs}

A11 "soft" rock (\$) $2,200 \quad 11,000 \quad 20,500 \quad 41,000 \quad 59,500$

A11 "hard" rock (\$) 4,000 20,000 $37,000 \quad 72,500 \quad 103,000$

Figure 20 illustrates the capital costs of drilling and casing a well in the Klamath Basin.

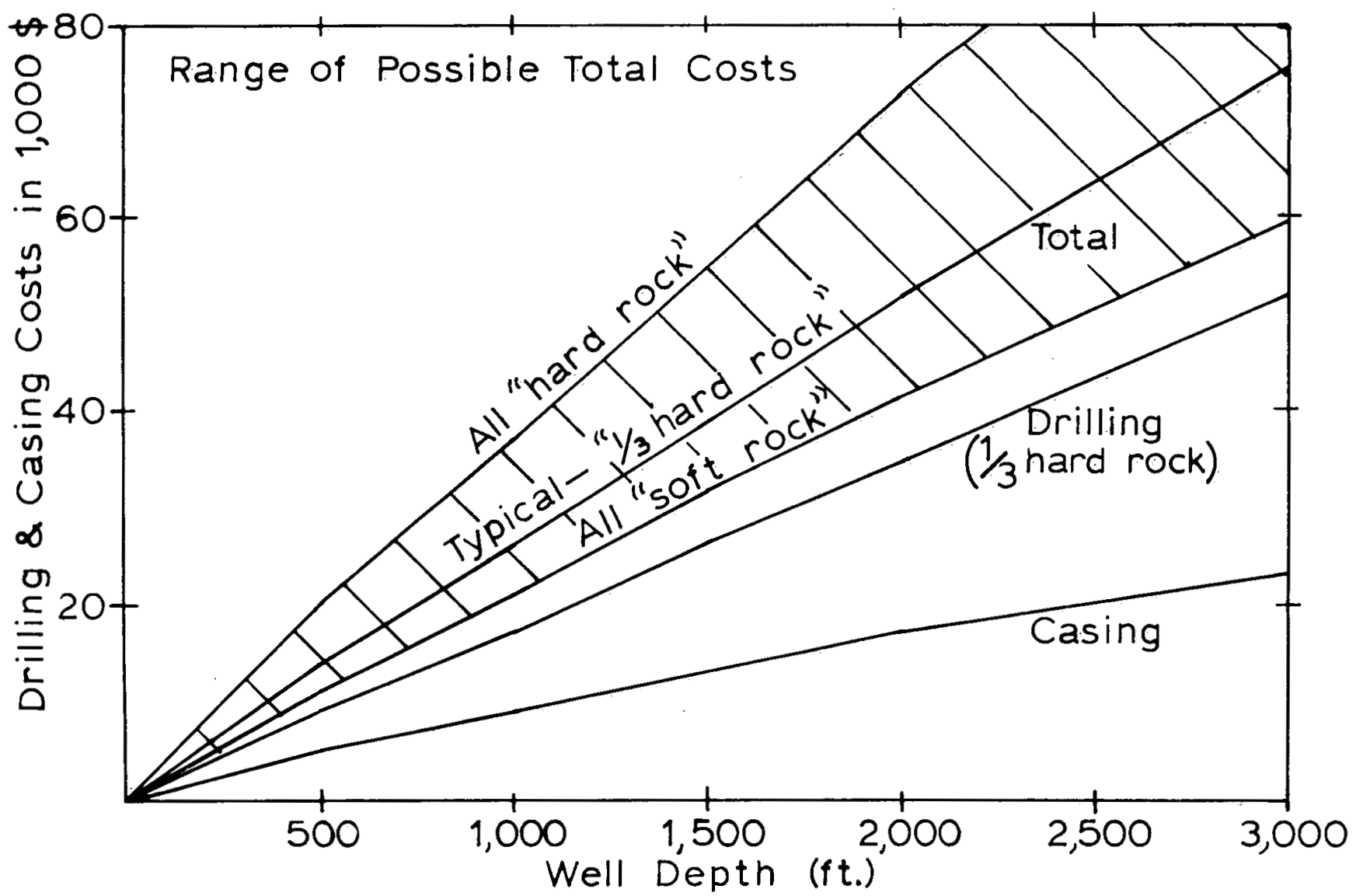

Figure 19. Drilling and casing capital costs 


\section{Transmission Costs}

Transmission costs will vary depending upon the quantity of fluid required and the size of pipe. Insulated asbestos cement pipe buried to a depth of three feet in soil with $\mathrm{K}=12 \mathrm{Btu} / \mathrm{hr}-\mathrm{ft}^{2}-\left({ }^{\circ} \mathrm{F} /\right.$ in $)$ is assumed for the transmission line for fluids with a temperature less than $210^{\circ} \mathrm{F}$. Sample costs are as follows:

\begin{tabular}{|c|c|c|c|c|c|c|}
\hline $\begin{array}{c}\text { Pipe } \\
\text { diameter } \\
\text { (inches) }\end{array}$ & $\begin{array}{l}{ }_{\text {Range }} \\
\text { (gpm) }\end{array}$ & $\begin{array}{l}\text { low Rates } \\
\text { Head loss } \\
(00.01 \mathrm{ft} / \mathrm{ft})\end{array}$ & $\begin{array}{l}\text { Insulated } \\
\text { pipe cost } \\
(\$ / \mathrm{ft})\end{array}$ & $\begin{array}{c}\text { Trenching } \\
\text { costs } \\
(\$ / \mathrm{ft}) \\
\end{array}$ & $\begin{array}{l}\text { Fitting } \\
\text { cost } \\
(\$ / \mathrm{ft})^{\star}\end{array}$ & $\begin{array}{r}\text { Total } \\
\text { cost } \\
(\$ / f t)\end{array}$ \\
\hline 3 & $25-225$ & (75) & 8 & 0.75 & 2.00 & 10. \\
\hline 4 & $50-400$ & (150) & 10 & 0.75 & 2.50 & \\
\hline 6 & $400-675$ & (375) & 12 & 1.00 & 3.00 & 16 \\
\hline 8 & $450-1500$ & (825) & 18 & 1.00 & 4.50 & 23. \\
\hline 10 & $600-2500$ & (1500) & 23 & 1.25 & 5.75 & \\
\hline 14 & $825-5000$ & $(3500)$ & 40 & 1.50 & 10.00 & \\
\hline
\end{tabular}

*Estimated a 25 percent of pipe cost.

Figure 21 illustrates the capital costs of a buried insulated asbestos cement transmission 1 ine.

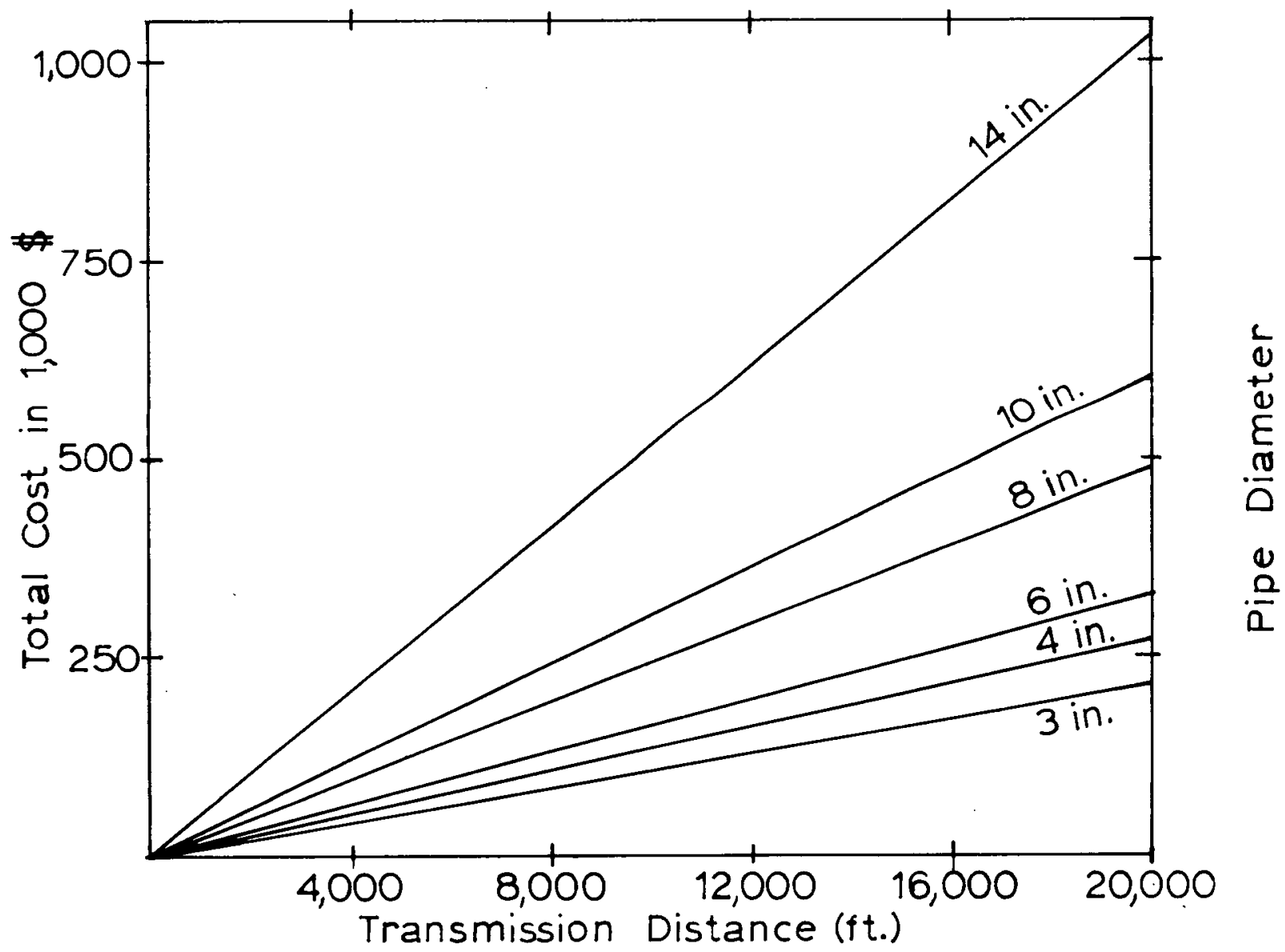

Figure 20. Insulated pipe costs

(asbestos cement pipe with urethane insulation) 
Geothermal fluids with temperatures greater than $21.0^{\circ} \mathrm{F}$ are transmitted to steel pipe, with bellows type expansion joints, insulated with a fiberglass wrap and housed in an enclosed concrete duct. A system of this type with an 8-inch insulated supply and bare return will cost approximately $\$ 80 / \mathrm{ft}$. 


\section{F. Institutional Factors}

Those environmental and regulatory factors directly related to the geothermal resource assessment will be addressed.

\section{Environmental}

\section{a. Drilling}

The areas under consideration in the two counties where wells may be drilled will be remote from urban and suburban populations with the exception of the Ore-Ida Foods, Inc. plant in Ontario, Oregon.

\section{1) Klamath Basin}

Rotary and cable tool drilling equipment should be able to complete wells in this basin. The terrain is flat so drilling wastes should not run off the property. Minimal noise, visual and social factors would be involved. Disturbances of biological communities should not be involved at the drillsite nor with wastes from the site. Return wells are recommended as the most environmentally feasible method of geothermal effluent disposal.

\section{2) Snake River Basin}

$0 i l$ well drilling equipment will most likely be utilized to drill wells up to $2 \mathrm{~km}$ deep. Noise controls would be required on all deep wells as free steam would most likely occur during and after drilling operations. The terrain at all sites would be flat so drilling wastes should not run off the property. Arrangements will need to be made with local authorities for drilling waste disposal. Some noise and social factors may be involved at the Ore-Ida site. Noise factors may be evident at the Amalgamated Sugar Company site. Disturbance of biological communities should not be involved at the drill sites nor with wastes from the site. Return wells are recommended as the most environmentally feasible method of geothermal effluent disposal for both sites.

\section{b. Disposal of Excess Water}

As more and more hot water is utilized in the Klamath Basin both for space heating or industrial applications (including anticipated agribusiness), there will be greater volumes of excess water that still contains some heat that will require disposal.

Hot waters in the $\mathrm{Klamath}$ Basin have relatively high concentrations of sodium and sulfate (Figure 19), with total dissolved solids from 750 to $900 \mathrm{mg} / 1$ (ppm). Hydrogen sulfide gas is detectable in most of them and the waters are clear and soft to moderately soft and slightly basic ( $\mathrm{pH} 7.5$ to 8.5). Iron, manganese, flourine, boron, or other toxic elements are within the range or below the standards 


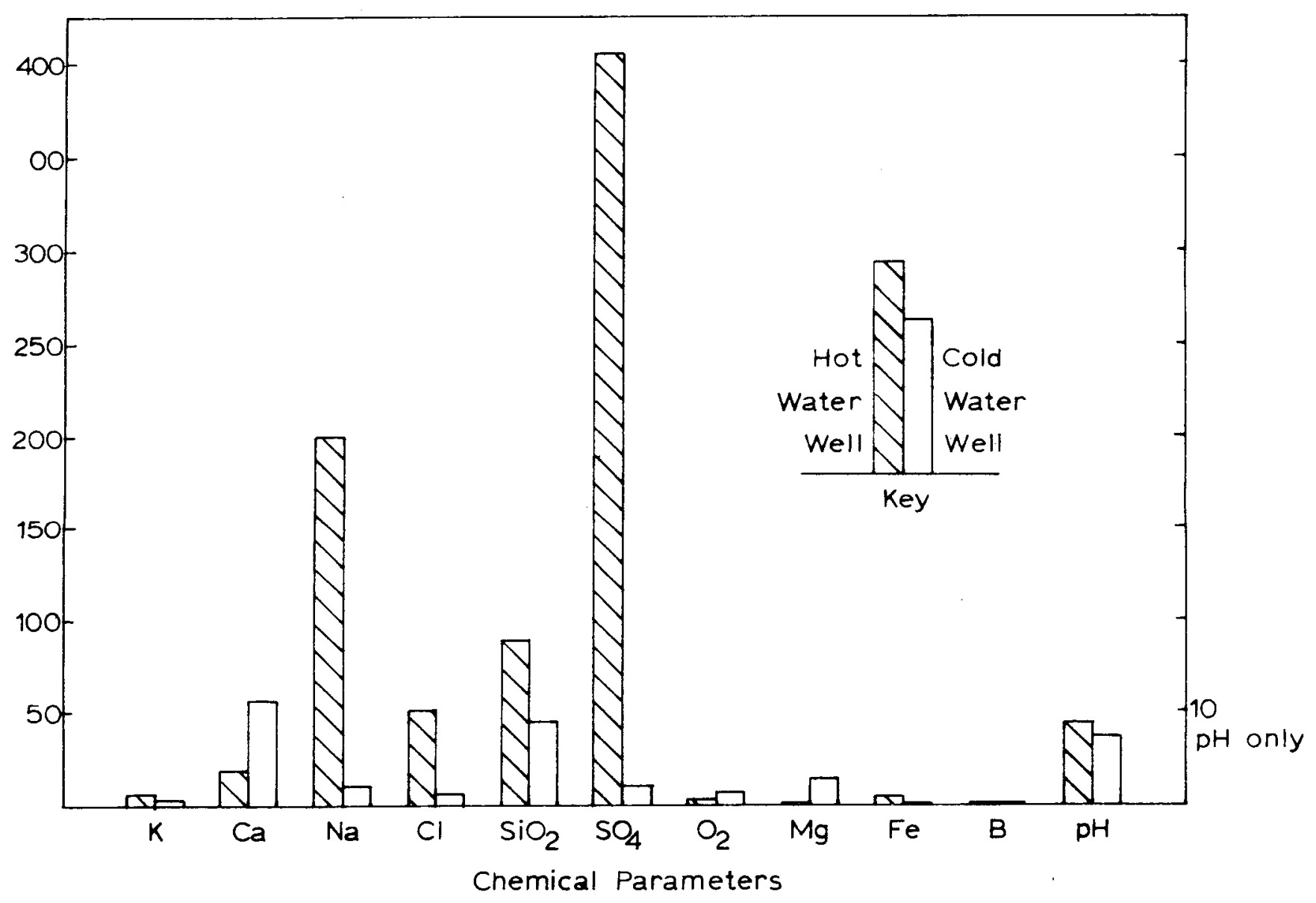

Figure 21. Klamath Bas in

Chemical composition of cold and heated groundwater. 
for drinking water recommended by the U.S. Public Health Service. Even though the total dissolved solids is above the $500 \mathrm{ppm}$ recommended for drinking water (Table I), the only radical that exceeds the standard is sulfate and that by only 100 to $200 \mathrm{ppm}$. It is very possible that the hot-water quality would be acceptable to many users even for drinking.

\section{TABLE I}

U. S. Public Health Service

Drinking Water Standards, 1962

\begin{tabular}{|c|c|c|}
\hline & $\begin{array}{c}\text { Recommended } \\
1 \mathrm{imit} \\
(\mathrm{ppm}) \\
\end{array}$ & $\begin{array}{c}\text { Maximum } \\
\text { A } 17 \text { owable } \\
(\mathrm{ppm}) \\
\end{array}$ \\
\hline Alkyl benzene sulfonate (ABS) & 0.5 & -- \\
\hline Arsenic & .01 & 0.05 \\
\hline Chloride & 250 & - \\
\hline Copper & 1.0 & -- \\
\hline Flouride & $.8-1.7$ & $1.6-3.4$ \\
\hline Iron & .3 & -- \\
\hline Lead & -- & .05 \\
\hline Manganese & .05 & -- \\
\hline Nitrate & 45 & -- \\
\hline Sulfate & 250 & -- \\
\hline Dissolved solids & 500 & -- \\
\hline
\end{tabular}

Excessive or abnormal heat added to surface water is sometimes considered to be a pollutant by restricting aquatic plants and animals or depleting oxygen.

It is very probable that in many cases in the Klamath Basin excess waters with some heat remaining could be disposed of at the surface in still ponds, spray ponds, or cooling towers with no adverse effect on the local surface waters.

Where surface disposal is not predictable, injection or return to the ground water reservoir may be the ultimate solution. This method of disposal has been used at Klamath Falls for a number of years and a history at three installations has been satisfactory with no apparent side effects.

c. Other Factors

\section{1) Klamath Basin}

Some odor effluent could exist from an onion dehydrating plant. The location of the dehydrator would govern whether the site would be close enough to human habitation where the problem could become offensive. 


\section{2) Snake River Basin}

No other environmental factors are evident at this planning stage.

2. Regulatory

\section{a. Federal}

Regulatory measures which may restrict acceleration of low- to moderate-temperature geothermal resource utilization are in two different areas of federal control. The first involves the general definition of geothermal resources which are identified with "all coal and other minerals." The second involves the regulation of geothermal fluid disposal, which is controlled by two public laws. Public Law (P.L.) 92-500, the Clean water Act, regulates the surface disposal of fluids and P.L. 93-523, the Safe Drinking Water Act, regulates the methods of reinjection of fluids into groundwater reservoirs.

1) Property owner rights to geothermal resources are not definite as a large quantity of western United States lands were obtained under the 1916 Stock-Raising Homestead Act which did not include mineral rights with the 1 and. The federal definition of geothermal resources includes them as a mineral so the resource is excluded from the rights of the landowner. The federal definition was upheld by a January 31 , 1977 decision of the Ninth District Court of Appeals in the case of United States vs. Union 0il Company No. 74-1574. Any entity intending to utilize geothermal resources should initially establish that mineral rights are included with the land at the prospective drill site.

Oregon congressmen in Washington, D.C. are trying to have the federal definition of genthermal resources restricted to those resources with temperatures greater tnan $121^{\circ} \mathrm{C}\left(250^{\circ} \mathrm{F}\right)$, and/or those taken from wells greater than 2,000 feet in depth, and to remove the "mineral" classification. This definition would correspond to Oregon's definition and geoheated water with temperatures less than $121^{\circ} \mathrm{C}$ and/or from shallower wells could be considered hot groundwater.

2) Surface disposal of geothermal fluid effluents is regulated by the Environmental Protection Agency (EPA) under rules stated in the Clean water Act of 1972, P.L. 92-500. The basic objective of the Act "is to restore and maintain the chemical, physical, and biological integrity of the nation's waters." Effluent limitations are defined for each source and an approved National Pollution Discharge Elimination System (NPDES) permit is issued to the individual permittee. Limitations could include temperature, chemical, and physical parameters. The NPDES permits for surface effluent discharges in Oregon are issued by the Oregon Department of Environmental Quality (DEQ) and entities considering 
a surface discharge of geothermal fluids should contact this agency. The DEQ office for central and eastern Oregon is located at Bend, Oregon.

Subsurface disposal of geothermal fluid is regulated by the EPA under rules stated in the Safe Drinking Water Act, P.L. 93-523, Section $C$. This law enters into reinjection plans for this project because of the relative purity of the geothermal fluids in the Klamath and Snake River Basins. The federal definition of drinking water includes those waters with less than 10,000 parts per million (ppm) of total dissolved solids (tds). Geothermally heated waters in both the basins of this study have tds of less than 1,000 ppm. Therefore, under this definition, the geothermally heated waters considered in this study are classified as drinking water. The need for reinjection exists where large quantities of heat energy need to be extracted from the resource and the geothermally heated fluid needs to be raised to the surface where heat extraction is most efficient. Wellhead heat extraction is necessary in most agribusiness industries considered in this study. The regulations related to reinjection in the Act are currently under revision but it is not known what, if any, modifications will be made for the final regulations. Considerable delays are expected in the development of geothermal resources if the regulations stand without modification. All inquiries relative to reinjection of geothermal effluents should be addressed to the DEQ and the Oregon Water Resources Department until a directive is issued by EPA.

The Resources Conservation and Recovery Act replaced and expanded regulations formerly contained in the Solid Waste Disposal Act. The new act is administered by EPA and contains rules related to liquid and contained gaseous wastes. This act and the Toxic Substance Control Act contain certain rules for geothermal waste disposal and may need to be addressed if gaseous wastes are present at the well site.

\section{b. State}

Regulatory measures at the state of Oregon level which may restrict development of low to moderate geothermal resources are related to: (1) groundwater rights; (2) reinjection procedures; and (3) surface discharge permits. Reinjection procedures and surface discharge permits have been addressed above under federal items.

The state of Oregon defines geothermal resources as those resources with temperatures greater than $121^{\circ} \mathrm{C}\left(250^{\circ} \mathrm{F}\right)$ and/or taken from wells deeper than 2,000 feet. The Department of Geology and Mineral Industries (DOGAMI) was given authority to regulate geothermal dri11ing by the 1971 Geothermal Act. Comprehensive regulations were promulgated under this statute in 1972. In 1957, the law was rewritten by the House Natural Resources Committee and was passed by 
the Oregon Legislative Assembly. The 1975 law required DOGAMI to draft Blowout Prevention Rules 60 days after the bill's passage. This was done and the bill has become a law. Copies of these regulations are available at the DOGAMI office. Geothermal resources other than those stated above are considered hot groundwater and their uses are regulated by the State Water Resources Department (WRD).

Groundwater rights must be established for demands exceeding 5,000 gallons per day which is about 210 gallons per hour or 3.5 gallons per minute. All agribusiness industries considered in this project would exceed this minimum quantity. Groundwater permits for beneficial uses are for domestic and stock uses and for irrigation. Several discussions have been held with WRD administrators to also permit "heat extraction" as a beneficial use. This has not as yet proven to be an obstacle in obtaining a permit but should be included in the published rules and regulations governing groundwater use. In the absence of WRD requlations governing geothermal resource use, each new application will be reviewed on a case-to-case basis.

Both the DEO and WRD are presently involved with permits for reinjection into groundwater reservoirs until final promulgation of the regulations contained in the Safe Drinking Water Act.

House Joint Resolution 50 was passed by the 1977 Legislative Assembly. This resolution directs the State Department of Water Resources, Geology and Mineral Industries, Energy, and Environmental Quality "to make a cooperative and coordinated effort to establish a policy and, if necessary, promulgate rules on the disposal of geothermal fluid." Two meetings have been held by these agencies, the first on August 23, 1977, and the second on 0ctober 11, 1977. Future meetings are planned. Representatives from the Region X EPA headquarters in Seattle, Washington and from the Oregon Land Conservation and Development Commission (LCDC) were invited to attend and contribute towards the success of the Legislative Directive. A11 institutional factors related to geothermal resources are being considered and acceptable geothermal waste disposal methods are the goals of the Interagency group.

c. Planning administrators in Klamath and Malheur Counties, Oregon are addressing geothermal resource uses when constructing the ir Comprehensive Land Use Plans. Several of the goals of the Oregon land use law as administrated by LCDC are indirectly related to geothermal resources. Comprehensive plans have not been completed for either Klamath or Malheur County so prospective developers of geothermal resources should communicate with the relevant County Planning Department. Citizen involvement is a major goal of the land use law but it is not anticipated that major problems will occur when developing the county's geothermal resources for agribusiness use. 


\section{ENGINEERING AND ECONOMIC ANALYSIS}

\section{A. Introduction}

Agriculture, wood products and recreation are the major industries in the Klamath Basin. Most people engaged in manufacturing are employed by the lumber and wood products industry.

Agriculture, food processing and recreation are the major industries in the Western Snake River Basin (Malheur County). In recent years over 95 percent of the value added by manufacturing in the county is from food processing.

In evaluating the potential of various geothermal applications to eneray intensive agribusiness industries to reduce product costs, the type of farm product and quantity produced in the Klamath and Western Snake River Basins were taken into consideration. The major farm products and existing processors in the two Basins are listed in Table II.

TABLE II. Klamath and Western Snake River Basin Farm Products. Klamath Basin, 1976

\section{Farm Product}

Alfalfa, 45,000 acres

Potato, 20,000 acres

Onions, 2,600 acres

Livestock, 118,000 head
One Pelleting Mill

Western Polymer Corp.

None

Two plants

$$
1976
$$

1975

Gross Farm Income from Crops

Gross Farm Income from Livestock
$\$ 31,345,000$

$36,703,000$
$\$ 24,269,200$

$29,271,000$

\section{Western Snake River Basin, 1976}

\section{Farm Product}

Hay Crops, 116,000 acres

Potato, 11,000 acres

Sweet Corn, 3,600 acres

Onions, 5,800 acres

Sugar Beets, 13,100 acres

Livestock, 195,000 head

Gross Farm Income from Crops

Gross Farm Income from Livestock
None

Ore-Ida Foods, Inc.

Ore-Ida Foods, Inc. \& Am.

Fine Foods

Ore-Ida Foods, Inc.

Amalgamated Sugar Co.

Four Plants

1976

$\underline{1975}$

$\$ 78,407,000$

$\$ 62,112,000$

$29,767,000$ 
This study involved determination of the energy needs and balances, the engineering analys is necessary to convert food processing plants to geothermal fluids and these were incorporated into the economic analyses. Data for this report was collected in cooperation with the personnel at Western Polymer Corporation, Amalgamated Sugar Company and Ore-Ida Foods, Inc. in the two Basins. Additionally, field trips were made to California and other areas of Oregon to collect data on prospective industries for the two study areas.

Based on selection criteria presented in section IV-B,2, three potential industries: onion dehydration, alfalfa drying and greenhouses were analyzed. These three industries would be applicable in either the Klamath or Snake River Basins. For each potential process analyzed in the following sections, assumptions were made on well depth, temperature, and production and transmission distances. Since these parameters will vary, depending on the actual site selected for development, (Figures 20 and 21) on drilling and transmission costs will enable the developer to make adjustments in costs. Changes in temperature ranges would also affect the conversion costs of equipment, and concepts developed for method of utilization. It would be wise for the companies using the results of this study to develop parametric models considering conceptual design change resulting from various quality possibilities of the geothermal resource. In some cases, additional heat may be necessary from conventional fuels in order to achieve temperature for certain processes or to meet seasonal or peaking requirements.

For each process analyzed, production costs using conventional energy (fuel oil, natural gas, coa1, electricity or other appropriate fuels) were determined so the economic benefits using geothermal energy could be calculated. These economic comparisons were made with cost projections of conventional fuel developed by the Oregon Department of Energy. The Department forecasts annual rate increases of 8 percent (private utilities) and 7 percent (public utilities) for electricity, 7 percent for petroleum products and 10.7 percent for natural gas through 1986, and 7 percent per year thereafter.

A comparison of industrial thermal energy price projections is illustrated on Figure 22, and assumes combustion efficiencies of 100 nercent for electricity, 80 percent for No. 2 fuel 011 and 90 percent for natural gas.

The rationale for forecasting conventional fuel cost projections by the Oregon Department of Energy is summarized in Appendix A.

The price escalations of conventional fuel exceed inflation rates for equipment purchase, installation, operating and maintenance costs. To show how inflation lowers the value of Present Worth calculations or increases future costs in terms of today's dollars, the following annual equivalent cost $(A)$ formula was developed (see Appendix B for derivation):

$$
A=\frac{a}{t-i}\left[(f / P)_{n}^{t}(P / f)_{n}^{i}-1\right](a / P)_{n}^{i}
$$




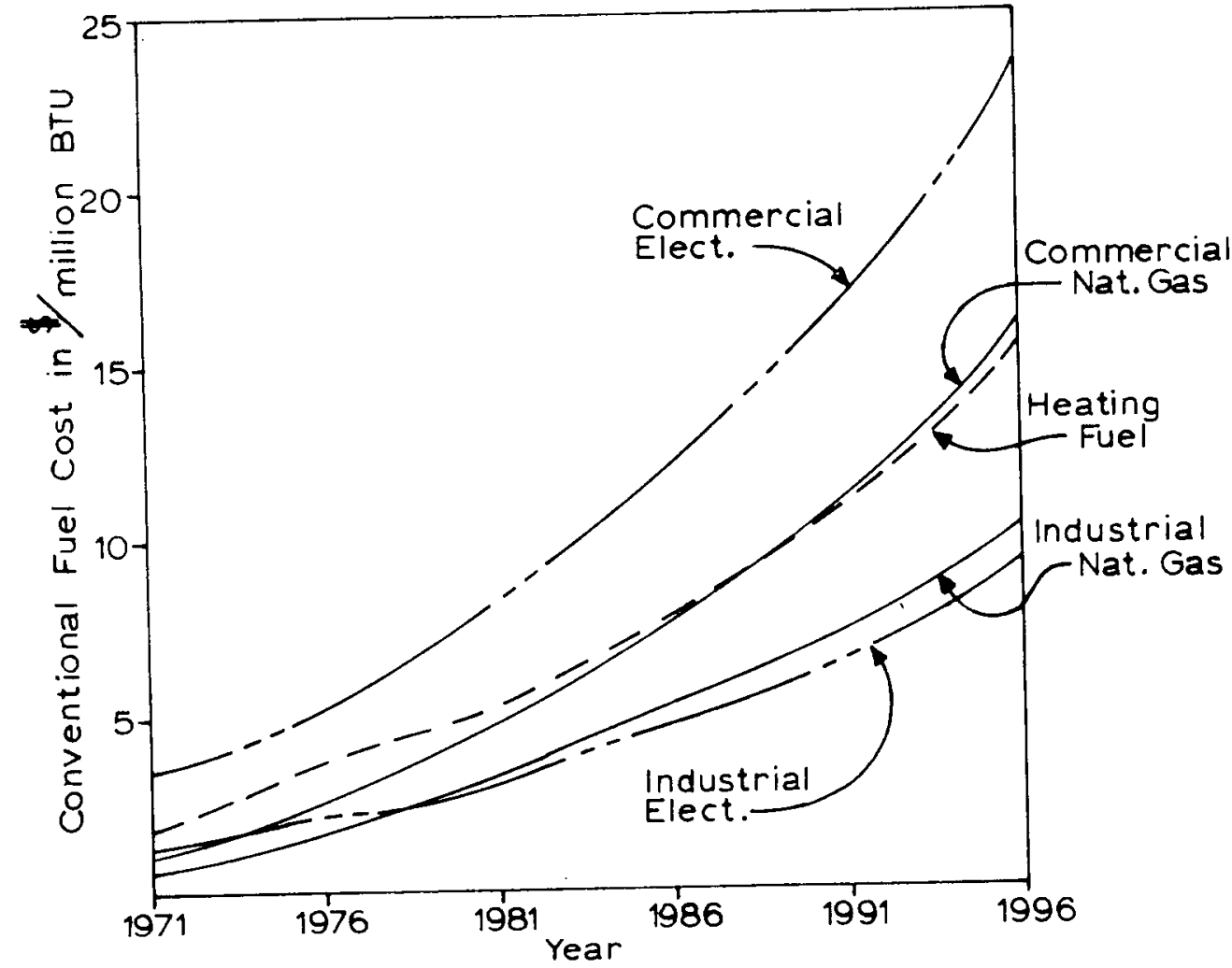

Figure 22. Commercial and Industrial Conventional Eneray Price Projections. 
where:

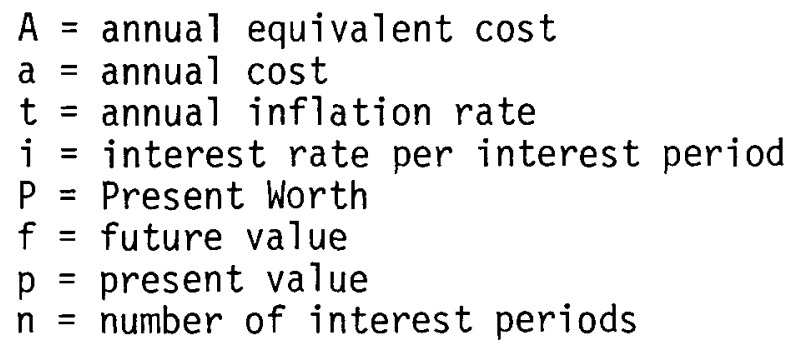

This formula was used to consider the cost of capital or return on investment (ROI) together with a predictable inflation rate to select the optimum alternative. The formula can be used as a part of any conventional annual cost model.

B. Klamath Basin, Oregon Assessment

1. Background and Selection Criteria

The capabilities of the Klamath Basin to produce agricultural crops to supply any agribusiness industry and to supply geothermally heated water to provide energy for such industries are directly related to the physical geography of the area. The Basin and its prime agricultural lands straddle the Oregon-California border along the east side of the high Cascades in the northwest corner of the Basin and Range geomorphic province. Quite recently in geologic time, block faulting and volcanic activities caused sunken areas (grabens) to contain large lakes whose outlets were blocked by lava flows. The $\mathrm{Kl}$ amath River cut through these flows but not until deep beds of organic materials were formed in the eutrophic lake bottoms. Most of the Basin's geothermal energy resource use has developed along the edges of the Klamath graben. Plentiful water supplies are discharged from ground water generated from water which precipitates into porous lava ash sails and porous basaltic rocks in the Cascades. Klamath Lake is the largest remaining natural water storage reservoir with an area of about 90,800 acres (about 142. square miles) and has a useable capacity of about 584,000 acre-feet. The lake and al1 agricultural lands in the Basin have an elevation of greater than 4,000 feet.

The climate is semi-arid, experiencing hot, dry summers, cold winters and moderate spring and fall temperatures. The average annual precipitation is 9 to 14 inches with maximums reaching more than 60 inches in the Cascades Mountain watershed area. Most of the precipitation comes as snow. The frost-free growing period in the agriculturally extensive area is 90 to 105 days with the possibility of light to killing frosts occurring any month of the year.

Agricultural activities began in the 1850s in the Basin and records of irrigated crops are as early as 1866. Major lake and marsh drainage projects were initiated in 1905 by the Bureau of Reclamation and most of the fertile farm lands are irrigated as a result of these activities. In 1964, 255,500 acres were irrigated and the quantity remains about the same today. 
Considerable amounts of hay and grains are grown to provide feed for large stock raising operations. Klamath County ranchers reported 118,000 cattle and 18,000 sheep in 1976. More than 87,000 acres of hay were grown in 1976 and a total of 124,000 acres of wheat, barley and oats were reported. Grain crop yields are good with wheat yielding 47 bushels per acre in 1971 when the state average yield was 44.9 bushels per acre (Karr, 1976). Other major crops are potatoes and dehydration-type onions. About 20,000 acres are planted to potatoes each year with most of the crop going to the seed and fresh markets. Average potato yields are about the same as in Malheur County or about 350 hundredweight per acre for an income of $\$ 16,900,000$ in 1976. While some onions are grown in Klamath County, Oregon, most are grown in the bordering areas in northern California.

The only agribusiness industry processing potatoes is a starch plant in Tulelake, California. An alfalfa pelleting plant runs a short seasonal operation near Klamath Falls. All other processing proceeds outside of the Basin with the raw material being transported from the area.

Geothermal energy could be utilized by dehydrator, greenhouse and aquaculture industries in the area but, as yet, this use has not been extensively pursued. Such actions could be used to reduce the wide fluctuations in farm and ranch incomes as the hot water resources are quite extensive. Greenhouse operations to grow tree seedlings, foliage plants, etc., could be used to extend the income producing season on an individual and/or cooperative basis. The Basin's shallow geothermal resources would aid in minimizing the costs of their utilization.

Comprehensive Land Use Plans have not been completed for Klamath County. County planners are awaiting the completion of this report to add the potentials for geothermal resource development to the economic portions of their plans.

\section{Selection Criteria}

In the Klamath Basin where agriculture is the major industry, there are only two agriculture processing plants other than dairies. These are the potato starch extraction plant of Western Polymer Corporation situated on the Oregon-California border 21 miles south of Klamath Falls and a pelleting mill located about 7 miles east of Klamath Falls.

In order to select agriculture processing industries that can benefit from the geothermal resources in the Basin, the following assumptions were made regarding the resource:

a. Geothermal resources exist in quantities at a maximum temperature of $195^{\circ}$ to $230^{\circ} \mathrm{F}$ in several separate localities of the $\mathrm{Kl}$ lamath Basin. Temperatures above $230^{\circ} \mathrm{F}$ may be found by exploration and exploitation of deeper reservoirs, however, at the time of this study the highest temperature discovered by drilling is $235^{\circ} \mathrm{F}$. 
b. Geothermal reservoirs can be drilled and tested to depths of 1500 to 3000 feet in depth and found to be productive at rates which will allow commercial development.

c. Geothermal fluid can be used directly in processing equipment (heat exchangers, fan coils, etc.) without adverse effects of fouling due to corrosion or scaling.

d. Rejected geothermal waters shall be injected into the ground via a well.

Potential processing industries were identified that could benefit from the temperature of the resources in the Basin. The industry selections were based on existing and potential crops grown in the Basin in terms of quantity and potential increase in production. Figures 23 and 24 illustrate processes and product matches that best fit the geothermal temperatures available, including consideration for using the geothermal energy as a preheat.

The final selection of applications to be analyzed and the reasons for their selection are as follows:

- Onion Dehydration

- Alfalfa Dehydration

- Potato Starch Drying

- Greenhouses

Onion Dehydration was selected because large quantities of low temperature energy is consumed in the process and the existence of an onion producing area in the Basin as well as the possibility of a large number of farms shifting to onion production.

Alfalfa Dehydration was selected because of the large quantities of alfalfa raised in the Basin and the potential for a large foreign export market of alfalfa processed with low temperature to retain xanthophyl1 and vitamin $A$.

Potato Starch Drying was selected because of an existing plant (Western Polymer Corporation, located near a resource site) that uses expensive LPG in a low temperature drying process.

Greenhouses were selected because of the large number of firms interested in locating in the Klamath Basin and the favorable location to transport products to markets both North and South. In addition there is a large need to supply seedlings for reforestation in the immediate area. The growing season is fairly short, 90 to 105 days in the Basin, thus greenhouses could extend the seasonal agricultural economy and provide jobs to reduce the 8.3 percent unemployment in the area. 


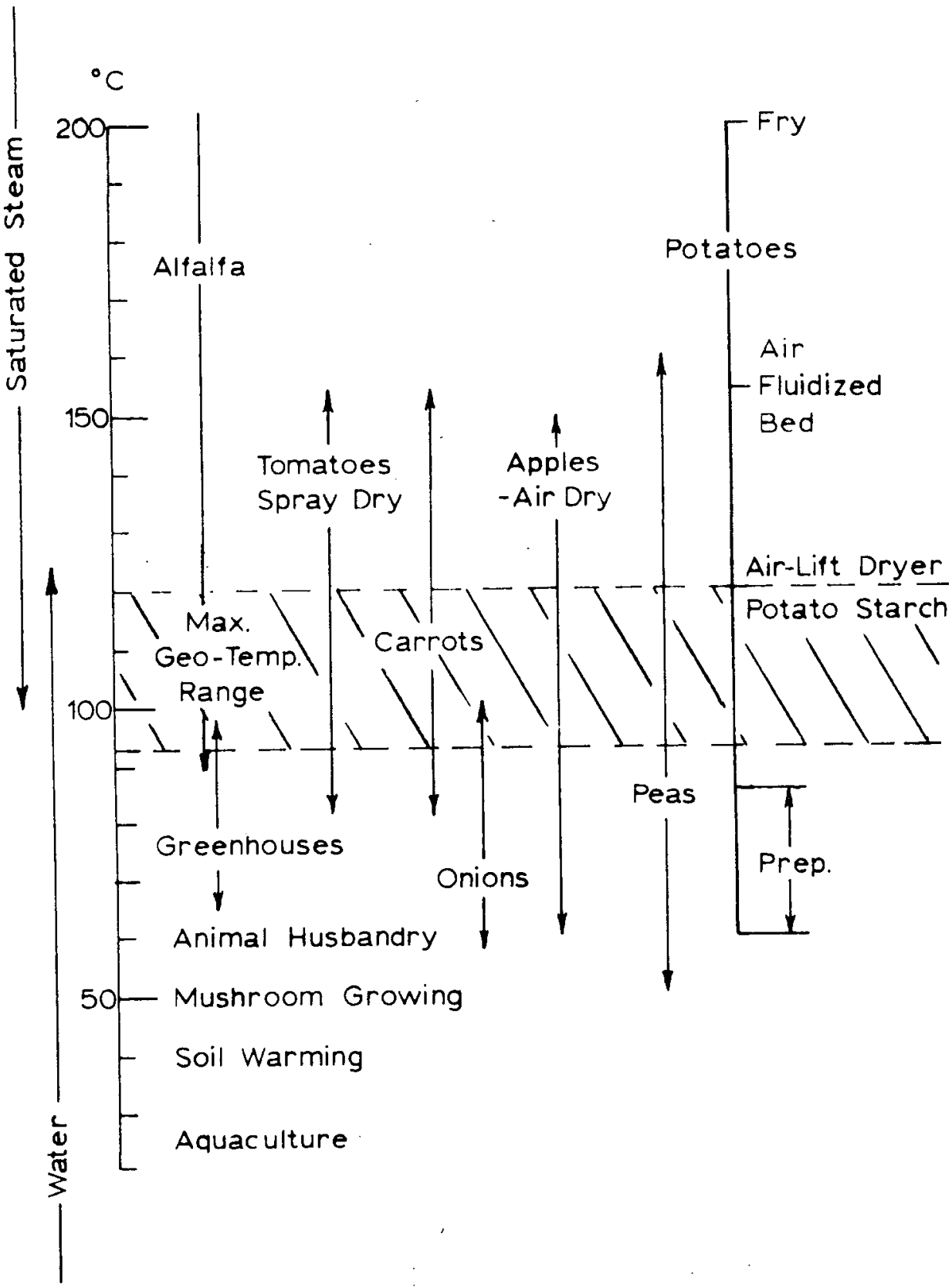

Figure 23. Process Temperatures for Potential Klamath Basin Products. 


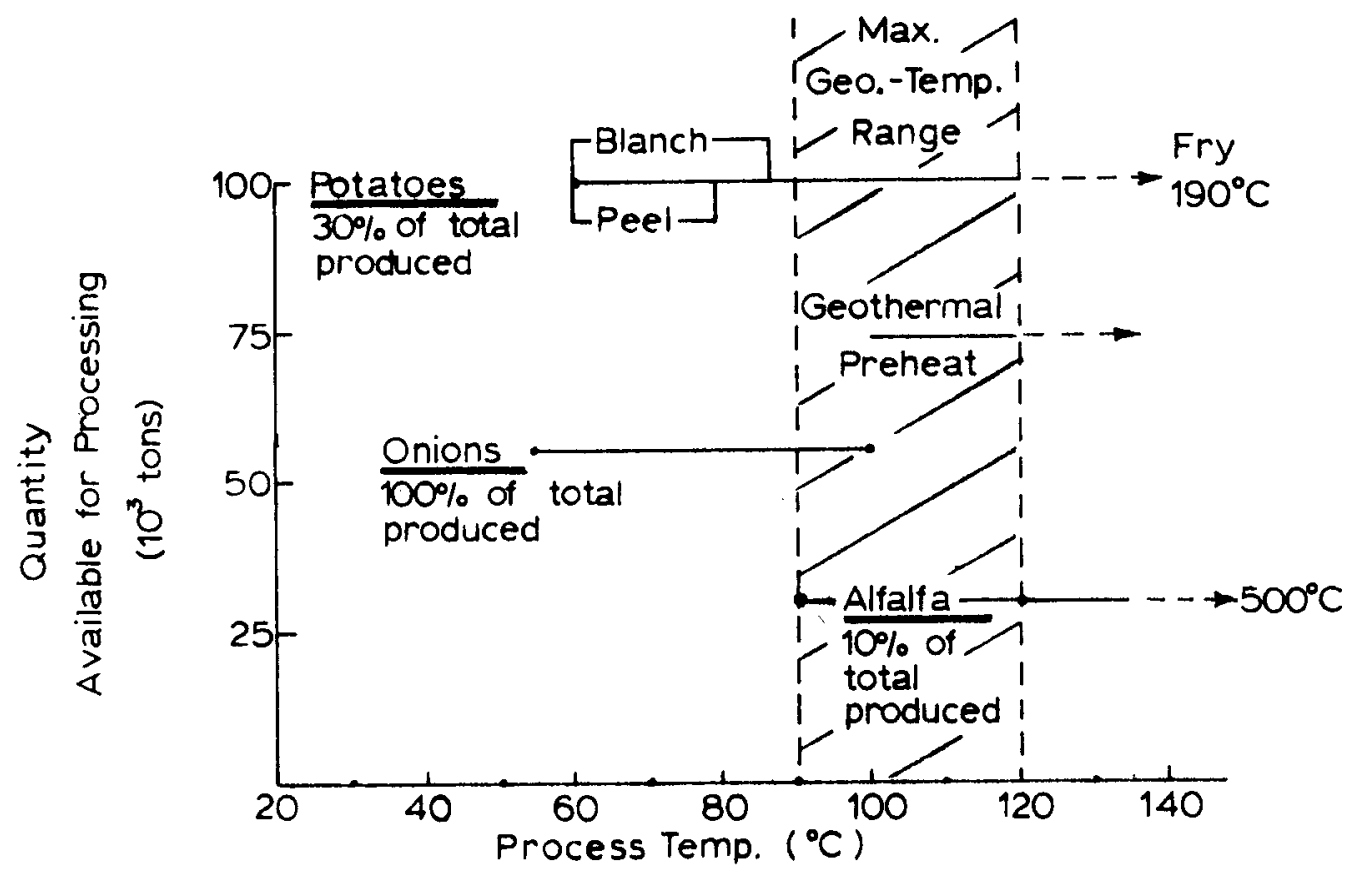

Figure 24. Existing Klamath Basin Agricultural Crops and Their Required Process Temperatures (1977).

2. Onion Dehydration

\section{a. General Description}

All onions for processing are grown from specific varieties best suited for dehydration. Specific strains of the Creole Onion, Southport Globe Onion, and the Hybrid Southport Globe were deve1oped by the dehydration industry. They are white in color and possess a higher solid content which yields a more flavorful and pungent onion.

Onion dehydration involves the use of a continuous operation, belt conveyor using fairly low-temperature hot air from $100^{\circ}$ to $220^{\circ} \mathrm{F}$. The heat originally was generated from steam coils, but now natural gas is more popular. Typical processing plants will handle 10,000 pounds of raw product per hour (single line), reducing the moisture from around 83 percent to 4 percent $(1,500$ to 1,800 pounds finished product). These plants produce $5 \mathrm{mil}$ lion pounds of dry product per year using from 0.15 to 0.20 therms per dry pound produced ( +0.06 therms of electrical energy), or 4,000 BTU per pound of water evaporated. 
The Tulelake area of California adjacent to the Oregon border will produce from 2,500 to 2,600 acres of Southport White Globe dehydrating onions this season, 1977. Approximate 1 y 1,900 acres were planted in 1975 and on1y 131 acres in 1976 . The onions are grown under contract between onion companies and the individual farmer. In 1977, four onion companies were involved in dehydrating the onions: Gentry International and Gilroy Foods, both of Gilroy, California; Basic Vegetable Products of Vacaville, California; and Rogers Brothers of Turlock, California. Approximately 45,000 pounds per acre will be harvested for a total of 58,500 tons. The product will be sold for $\$ 3.15$ per 100 pounds (loaded in trucks) to the four onion dehydration companies. Onions are not grown in the Oregon side of the Klamath Basin due to the additional cost of transporting them across the state line (estimated at $\$ 0.15$ per 100 pounds) to the processing plants. The season lasts from late April to harvest time in october and November. This season could be extended in the Klamath Basin by raising onion transplants in greenhouses, thus increasing the processing period. The single-iine, four-stage dehydrator requires $35.0 \times 10^{6} \mathrm{lb}$ of raw products which would produce $5.2 \times 10^{6}$ 1b of dehydrated product in a 150-day season. This is equivalent to the production of about 440 acres of good onion-producing land. It appears that the existing crop from the Tulelake area could support from five to six of the singleline dehydrators operating 150 days on a 24-hour-day basis, and if plants could be set up on the Oregon side, many farmers would enter the onion-growing business. The advantages for locating a dehydrating plant in the Basin, in addition to using geothermal energy, are the cooler climate, 4,100-foot elevation, for excellent field storage conditions and the low relative humidity of the area. The disadvantage is a short growing season which could be compensated for by greenhouse transplants.

One processing plant has been toured and discussions held with an equipment manufacturer to better understand the general processing steps and energy inputs. Some general details were obtained from these discussions. However, due to the competitiveness of the industry, specific details and energy requirements were difficult to obtain. Most of the details have been obtained from "Economic Study of Low Temperature of Geothermal Energy in Lassen and Modoc Counties, California," by VTN-CSL for the State of California, 1976, and "Application of Solar Energy to Continuous Belt Dehydration," Final Report by Trident Engineering Associates, Inc., for ERDA, 1977.

An example of one type of processing equipment, the Proctor dehydrator, is a single- 7 ine unit 212 feet long and 12.5 feet wide, requiring $86,500 \mathrm{ft}^{3}$ of air per minute and up to 40 million BTU per hour. Due to the moisture removal, the air can in some cases only be used once, and thus is exhausted. Special silica gel--Bryair, desiccation units are required in the final stage. Approximately $\$ 200,000$ in fuel are thus used for a single-line dryer in a year's operation (180 days). 


\section{b. Processing Steps}

Onion dehydration using a continuous conveyor dryer involves the following basic steps: a) harvesting, b) transporting to the plant, c) curing, d) washing, e) slicing, f) dehydration in four stages, g) milling, and h) packaging. Each of these steps is discussed in detail for a Proctor (Proctor and Schwartz, Inc. of Philadelphia) dehydrator. A cross-sectional diagram of a typical dryer is shown in Figure 25.

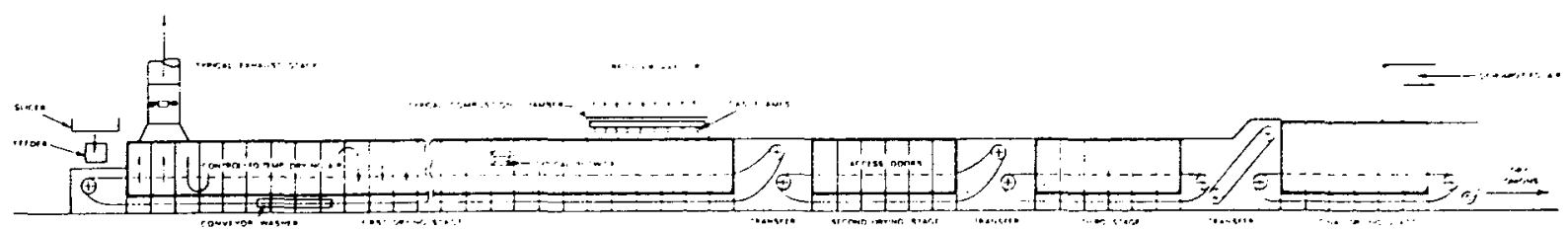

Figure 25. Proctor Continuous Automatic Onion Dehydrator.

Harvesting is accomplished mechanically by specialized equipment that is designed and fabricated by the processing industry. Harvesting is accomplished by a small crew of 20 to 30 people used to inspect the onions and to operate the equipment. The onions are topped, dug, inspected, and loaded into bulk trucks holding about 50,000 pounds each.

The trucks loaded with onions are taken directly to the plant. They are loaded into large curing bins where excess moisture is removed by passing large volumes of heated air $\left(100^{\circ} \mathrm{F}\right)$ through the onions. Curing conditions the onions so that peeling and processing can be accomplished successfully.

After curing for 48 to 72 hours, the onions are passed into the processing line. The earlier method of scooping up the onions with a tractor has been replaced with an automatic conveyor system that gently carries them to the preparation line. Machines 
automatically remove any tops that may remain attached to the onions. They are than inspected, washed in a high-pressure washer, soaked in a stainless steel tank to remove sediment, washed again in a high-pressure washer, and resoaked in a bath of highly chlorinated water in order to reduce bacteria to the lowest possible level. The onions are then reinspected and placed in stainiess steel surge tanks. Two large stainless steel tanks are used so that one can be washed as the other is being used. The onions are fed out of the surge tanks into the slicers. Razor-sharp rotating knives cut the onions into uniform slices, which are then passed to the dryer.

From the slicers a continuous and uniform flow of onions is conveyed to the wiper feed that carries the sliced product laterally across the open feed end extension. Here the onions are carefully transferred to the dryer conveyor for the first stage of drying. This is the most critical stage, where, under high-volume air flow conditions and with moderately high temperatures, the bulk of the water is rapidly removed from the onion. The moisture content of the onions is reduced from an initial 83 percent to 25 percent. This is called the "A" stage, where onion loading depth is approximately four inches.

Absolute uniformity and controlled depth of loading on the dryers is necessary to prevent "pinking," an enzymatic discoloration that can take place in the onion slice if proper drying conditions are not maintained. The pure white color of the discharged product from this drying stage is a test of the high quality of the product. Normal drying temperature for stage "A" is around $220^{\circ} \mathrm{F}$; however, temperatures as low as $180^{\circ} \mathrm{F}$ can be used. The lower temperature will increase the processing time; however, the quality will be improved.

High-powered blowers and exhaust fans move the air over natural gas burners, and through the beds of onions on the dryer conveyor, to evaporate the necessary tons of water removed from the product each hour. Close air volume and pressure control must be maintained in all parts of this drying stage as the air moves up and down through the bed to obtain product drying uniformity. Automatic temperature controllers and a long list of safety devices control the continuous operation.

At the proper point in the drying process, the onions are automatically transferred to the second stage (" $B$ " stage) of drying where, under reduced temperature conditions and deeper bed loadings (approximately 12 inches), the difficult to remove diffused water is slowly withdrawn. Here, moisture content is reduced to 10 percent. At the special transfer zone, the onions are gently handled by rotary devices that assure ful1 removal from the first-stage dryer and separation removal of clumps for uniform second-stage loading. 
The second stage of drying transfers to the third stage (" $\mathrm{C}$ " stage) with even deeper loading (approximately 30 to 40 inches deep), as the deeply diffused water becomes even more difficult to remove. Moderating temperatures and air flows are used to maintain close product temperature control as a steady evaporation of water is reduced from each onion slice and the evaporative cooling effect can no longer be counted on to maintain the low product temperature required for maximum product quality. After leaving the " $\mathrm{C}$ " stage, moisture content is down to 6 percent.

A special unloader takes the now nearly dry onions off the thirdstage conveyor, transferring them to the elevating conveyor for the fourth and final stage of dehydration. Here, conveyor loading depths up to six feet are used for final moisture reduction and equilibration. Dehumidified air from a two-stage desiccation unit is counterflowed through this deep layer to bring the finished onions to the point (about 4 percent moisture) where milling can best be accomplished and shelf life maintained.

After drying, the onions are passed over a long stainless steel vibrating conveyor that gently carries them to the milling area. In the mill, skin is removed by aspirators from the onion pieces. The onions are then milled into sliced, large chopped, chopped, ground, granulated and powdered onions.

\section{c. Power Production and Energy Requirements}

The energy requirements for the operation of a dryer will vary due to differences in outside temperature, dryer loading, and requirement for the final moisture content of the product. A single-line Proctor dryer handling 10,000 pounds of raw product per hour $(1,500$ tc 1,800 pounds finished) will require about $5.0 \times 10^{8}$ BTU/day, or for an average season of 150 days, $7.6 \times$ $10^{10}$ BTU/season, using approximately 0.15 therms per pound of dry product. This is estimated to cost from $4 \phi$ to $5 \phi$ per pound of finished product.

The energy is provided by natural gas; air is passed directly through the gas flame in stages $A$ and $B$, and over steam coils in stages $C$ and $D$. The steam coils are necessary to prevent turning of the onions in the last two stages.

In addition to the heating requirements, electrical energy is needed for the draft and recirculation fans and small amounts for controls and driving the bed motors. Total electric power required for motors is from 500 to 600 horsepower, or about $1 \times 10^{4} \mathrm{KWh} /$ day, or $2 \times 10^{6} \mathrm{KWh} / \mathrm{season}$. This amounts to 0.01 therm per pound of finished product and increases to about 0.06 therm per pound when all electrical requirements are considered. 
The details of each stage of a typical process are as follows:

\begin{tabular}{|c|c|c|c|c|c|c|}
\hline Stage & $\begin{array}{c}\text { Size } \\
\text { (length) } \\
\end{array}$ & $\begin{array}{l}\text { Motor } \\
\text { output } \\
\text { (hn) }\end{array}$ & $\begin{array}{l}\text { Air } \\
\text { Temp. } \\
{ }^{\circ} \mathrm{F} \\
\end{array}$ & $\begin{array}{c}\text { Air } \\
\text { Volume } \\
\text { CFM* } \\
\end{array}$ & $\begin{array}{l}\text { Depth } \\
\text { of } \\
\text { onions } \\
\end{array}$ & $\begin{array}{l}\text { Moisture } \\
\text { Content }\end{array}$ \\
\hline$\frac{\text { Curing bins }}{\text { transfer }}$ & $100 \times 100$ & -- & 100 & variable & variable & $80-85$ \\
\hline A $\frac{(4 \text { compartments })}{\text { transfer }}$ & $73 \mathrm{ft}$ & 400 & $190-220$ & 230,000 & 4" & $20-25$ \\
\hline$B\left(\frac{2 \text { compartments })}{\text { transfer }}\right.$ & $25 \mathrm{ft}$ & 90 & $155-170$ & 60,000 & $12^{\prime \prime}$ & $12-16$ \\
\hline C $\frac{(2 \text { compartments })}{\text { transfer }}$ & $25 \mathrm{ft}$ & 70 & 135 & 70,000 & $30-40^{\prime \prime}$ & $6-8$ \\
\hline D $\frac{(2 \text { compartments })}{\text { transfer }}$ & $25 \mathrm{ft}$ & 40 & 120 & 20,000 & $60-70 "$ & $4-5$ \\
\hline
\end{tabular}

*Some air may be recirculated depending upon moisture content.

In general, four stages (A through D) are preferred; however, if the ambient air humidity is below about 10 percent, stage $D$ can be eliminated. This is not felt to be possible in the Klamath Basin. Also temperature and number of compartments in each stage may vary.

Stage D, supplying desiccated air with a Bryair unit, reduces the moisture content of the product to a point below that of the ambient air. The unit is divided into two sides: the process side, which supplies desiccated air to the dryer after it has been passed through silica gel beds; and the reactor side in which heated air is passed over the silica gel beds in order to remove the moisture which had been absorbed in the process side.

The process air is drawn in from the outside under ambient conditions of temperature and humidity, nassed through a filter and a cooling coil, and then is circulated through the dry silica gel beds where some of the moisture is absorbed. The process air then is drawn out by a fan and directed to the D2 stage of the dryer. This process air leaves the Bryair unit at a temperature of about $120^{\circ} \mathrm{F}$ with a moisture content of about 30 grams per pound ( $4 \mathrm{~g}$ per $\mathrm{kg}$ ).

On the reactor side, ambient air is drawn into the intake and passed over a gas burner which heats the air. to about $250^{\circ} \mathrm{F}$, after which the air is circulated through the silica gel beds so that the moisture which had been absorbed in the process side is removed. 
A suction fan on the discharge side then exhausts the moistureladen reactor air to the atmosphere at temperatures of from $150^{\circ}$ to $225^{\circ} \mathrm{F}$. A slight pressure differential is maintained between the process and reactor sides so that air is prevented from leaking to the process side from the reactor side.

In summary, total energy requirements are as follows: Singleline Proctor dehydrator approximately 210 feet long by 12.5 feet wide; averaqe input 10,000 pounds wet product (15-20 percent solids) producing 1,500 to 1,800 pounds dry product (9596 percent solids) per hour requires $2.2 \times 10^{7} \mathrm{BTU} / \mathrm{hr}$ of heat energy or $9.5 \times 10^{10}$ BTU/season (180 days).

A specific example of a proctor dehydrator is detailed in Table III, and Fiqures 26 and 27 . The total energy requirements, using natural qas as a fuel, varies from 21 to $26 \times$ $10^{6} \mathrm{BTU} / \mathrm{hr}$ depending upon the ambient air varying from $65^{\circ}$ to $40^{\circ} \mathrm{F}$. Air flows denend unon temnerature and amount of recirculated air--which could only be estimated.

TABLE III

Onion Dehydration

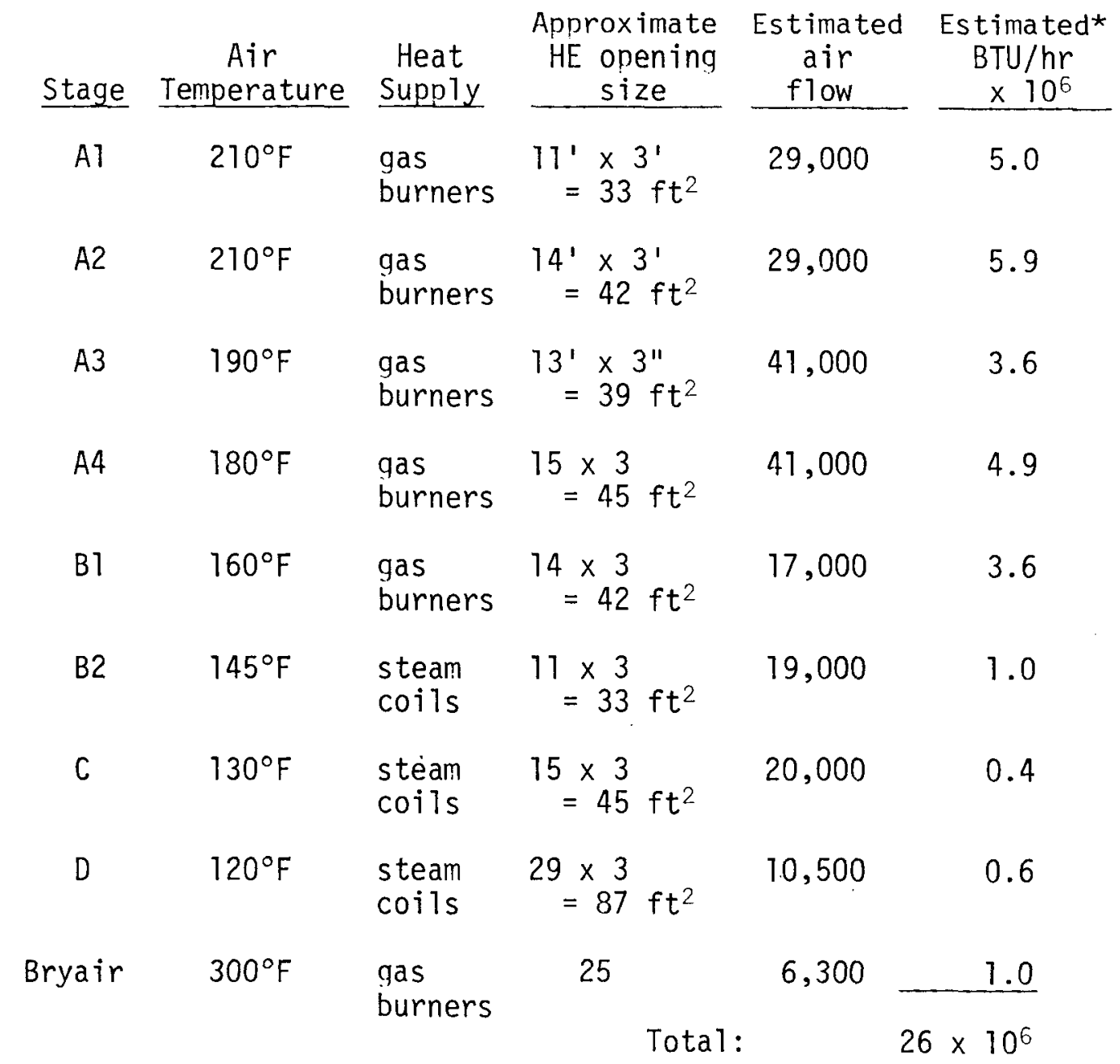

*assuming ambient at $40^{\circ} \mathrm{F}$; total $=21 \times 10^{6} \mathrm{BTU} / \mathrm{hr}$ at $65^{\circ} \mathrm{F}$ ambient. 


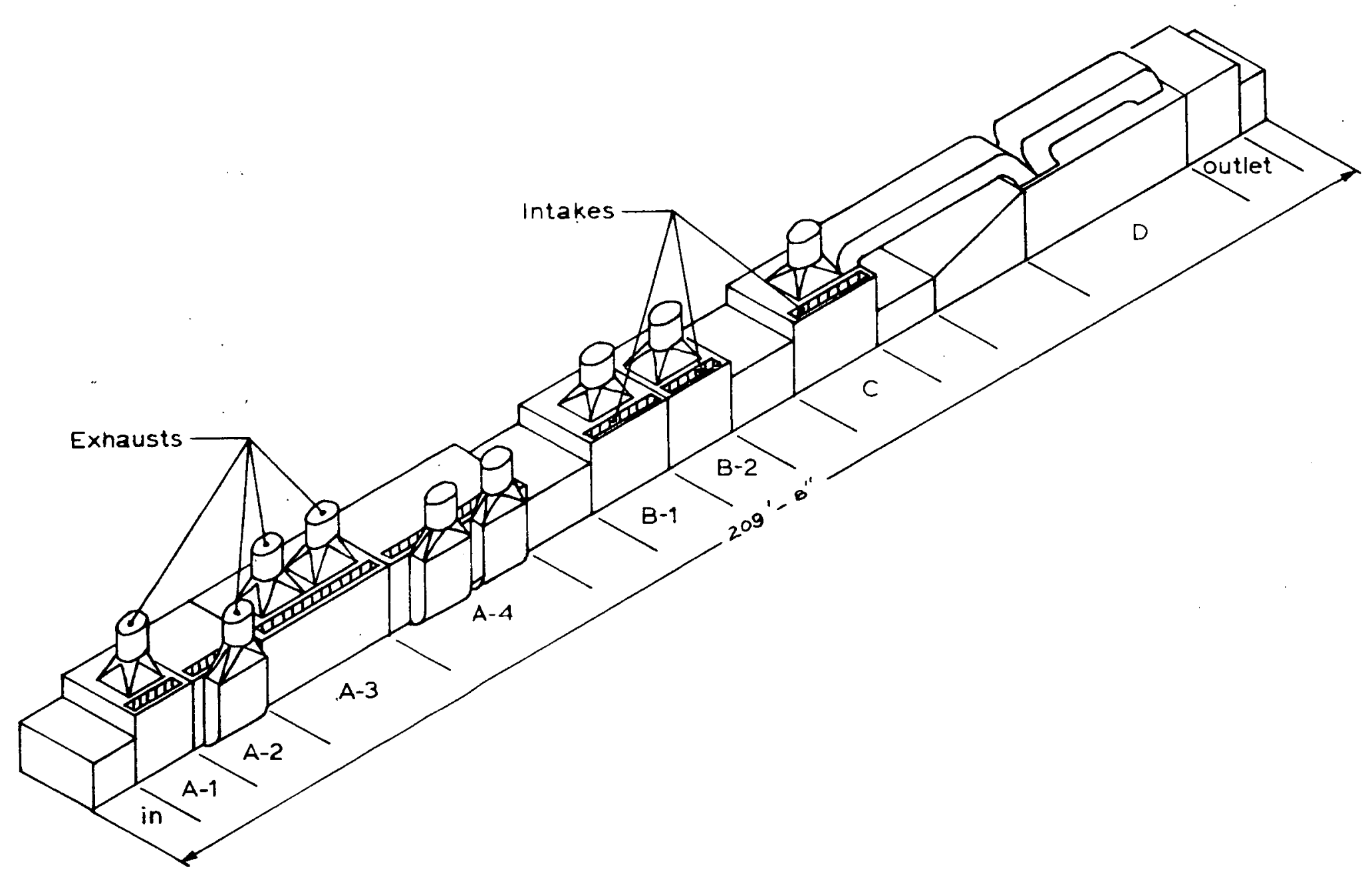

Figure 26. Single-Line Onion Dehydrator. 


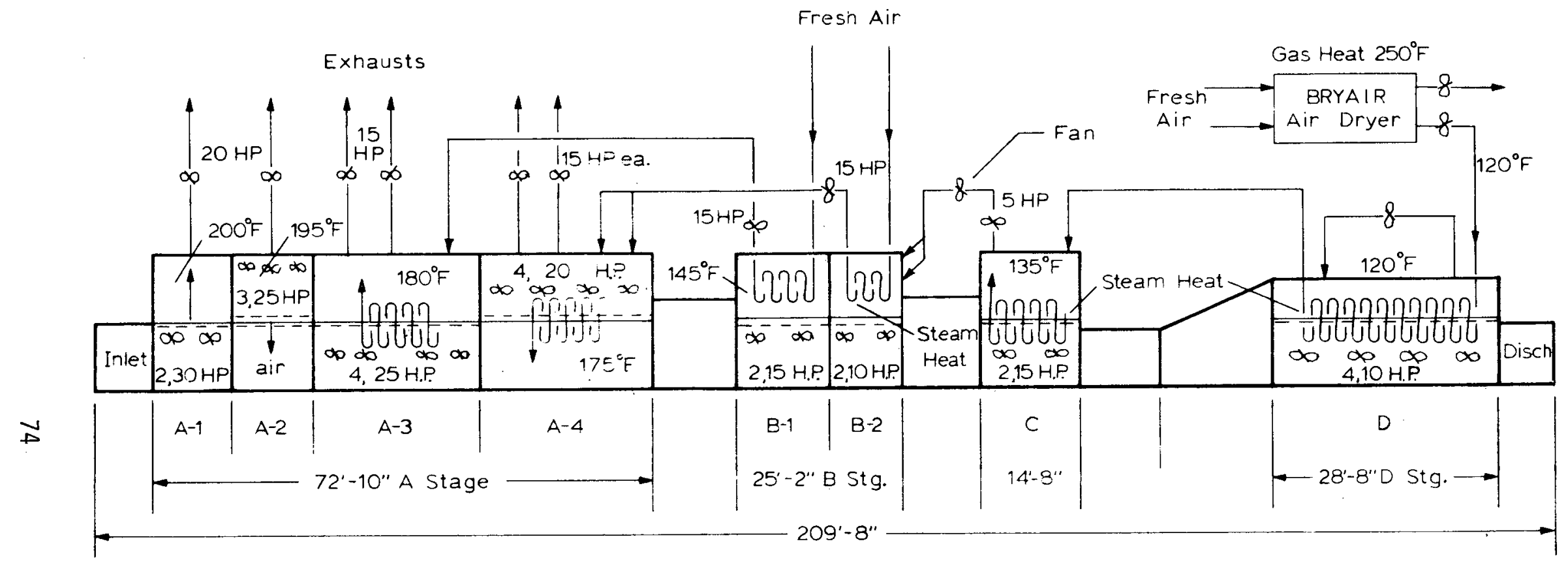

Tamb.

Energy into Air BTU/hr. $\times 10^{3}$

$65^{\circ} \mathrm{F} \quad 4,260 \quad 4,897 \quad 3,164$

$4,200 \quad 2,800 \quad 783 \quad 3,75$

$40^{\circ} \mathrm{F} \quad 5,040 \quad 5,839 \quad 3,597$

4,895

$3,624 \quad 987$

420

Bed Width $12^{\prime} 5^{\prime \prime}$

$\begin{array}{lll}218 & 245 & 892 \\ 292 & 254 & 920\end{array}$

Figure 27. Temperature and Energy Requirements for Each Compartment of a Single-Line Onion Dehydrator. 


\section{d. Geothermal Applications}

Using the specific example detailed in Table III and Figures 26 and 27 , a design was made to convert the Proctor dehydrator to geothermal energy. Using a $20^{\circ} \mathrm{F}$ minimum approach temperature between the goethermal water and process air, a well with $230^{\circ} \mathrm{F}$ water is required. This temperature is available in the Klamath Basin; however, a deeper well (up to 2,000 feet deep) will probably be required.

The first-stage air temperature can be as $10 \mathrm{w}$ as $180^{\circ} \mathrm{F}$; however, temperatures above $200^{\circ} \mathrm{F}$ are desirable, as indicated by people in the industry.

Figure 28 indicates Design I using $230^{\circ} \mathrm{F}$ water. The line has to be split between compartments A-1 and A-2, since both require $210^{\circ} \mathrm{F}$ air temperature. A total of $900 \mathrm{gpm}$ is required. Two wells can probably supply this volume, as 500 to $600 \mathrm{gpm}$ have been pumped from existing wells in the Basin. The Bryair desiccator requires $300^{\circ} \mathrm{F}$ on the reactor side, thus only half of the $1.0 \times 10^{6} \mathrm{BTU} / \mathrm{hr}$ energy requirements can be met geothermally. Geothermal heat will be used for preheating to $175^{\circ} \mathrm{F}$, with natural gas or propane used to boost the air to $300^{\circ} \mathrm{F}$. The waste water from the Bryair preheater has a temperature of $192^{\circ} \mathrm{F}$, thus this could be used for space heating, greenhouses or other low-temperature energy needs. The waste water would be returned by an injection well.

Design I considers the ambient air to be $40^{\circ} \mathrm{F}$ (worst conditions), while Design II considers a $65^{\circ} \mathrm{F}$ air temperature. This will reduce the required flow to $760 \mathrm{gpm}$, however, still requiring two production wells.

Design III uses $220^{\circ} \mathrm{F}$ geothermal water and $200^{\circ} \mathrm{F}$ air temperature for compartment $A-1$. This requires $975 \mathrm{gpm}$, or aga in two wells.

In compartments $A-1, A-2, A-3$ and $A-4$, four finned air-water heat exchangers in parallel would be required to satisfy the energy requirement and water velocity flows. The remaining stages would require from one to two heat exchangers in each compartment, depending upon the energy requirements.

The details of the flow patterns for Designs I, II and III are shown in Figures 28,29 and 30 .

The layout of the plants and wells are showing in Figure 31 . A 1,000-foot production well spacing is assumed, each 2,000 feet deep. The supply line will be insulated asbestos cement and buried. 
GEOTHERMAL ONION DEHYDRATION

Design I

$40^{\circ} \mathrm{F}$

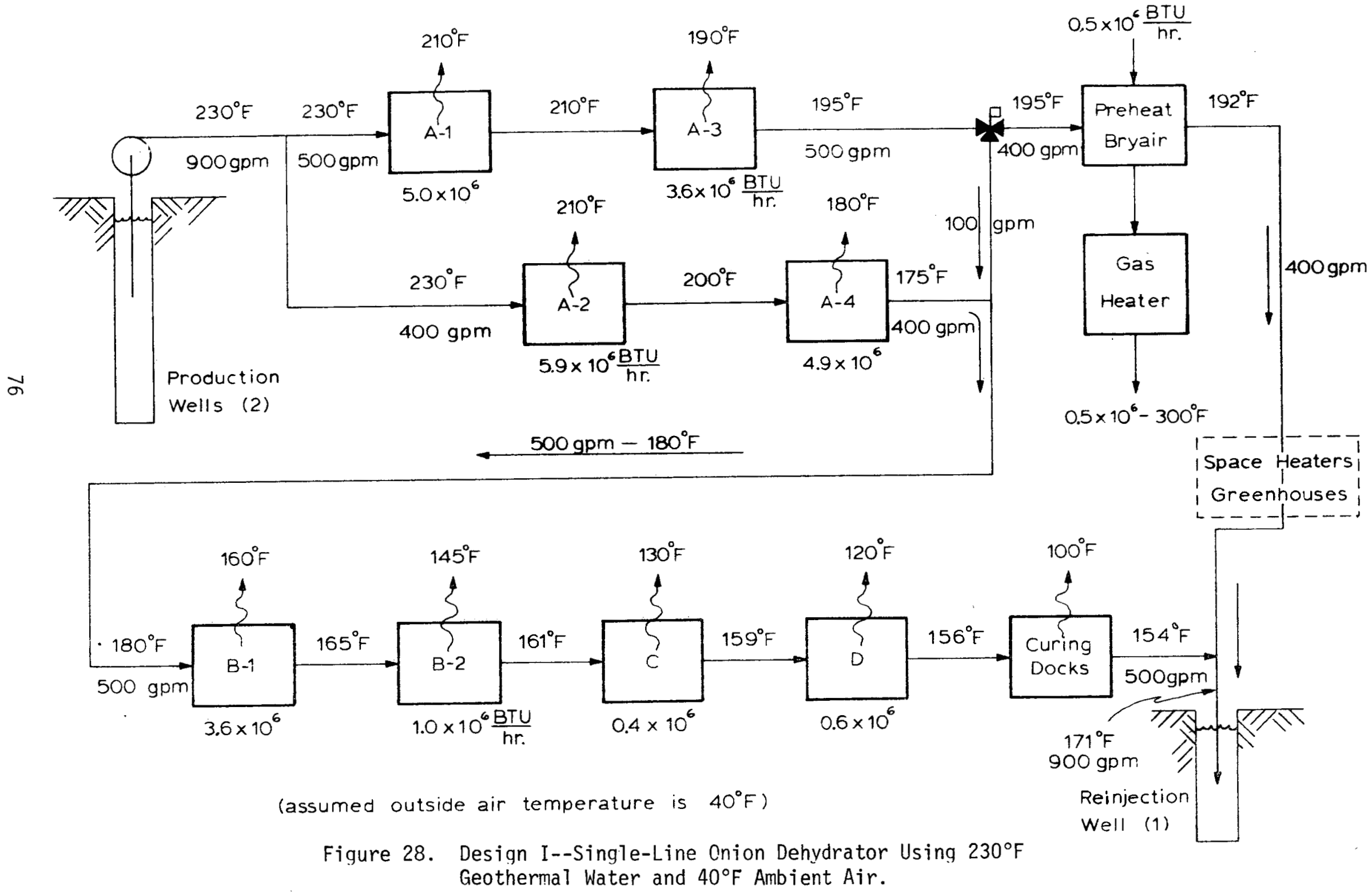

Figure 28. Design I--Single-Line Onion Dehydrator Using $230^{\circ} \mathrm{F}$ Geotherma? Water and $40^{\circ} \mathrm{F}$ Ambient Air. 


\section{GEOTHERMAL ONION DEHYDRATION \\ Design II}

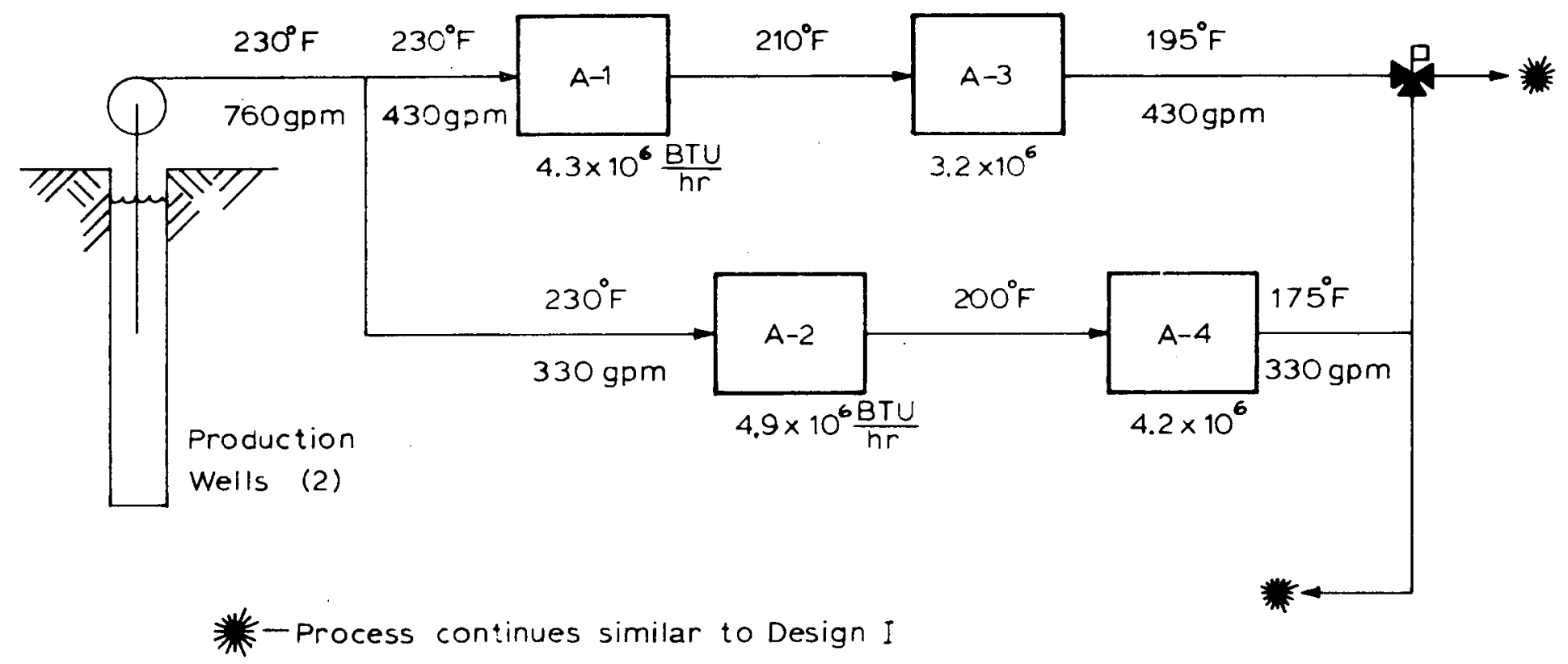

(assumed outside air temperature is $65^{\circ} \mathrm{F}$ )

Figure 29. Design II--Single-Line Onion Dehydrator Using $230^{\circ} \mathrm{F}$ Geothermal Water and $65^{\circ} \mathrm{F}$ Ambient Air. 


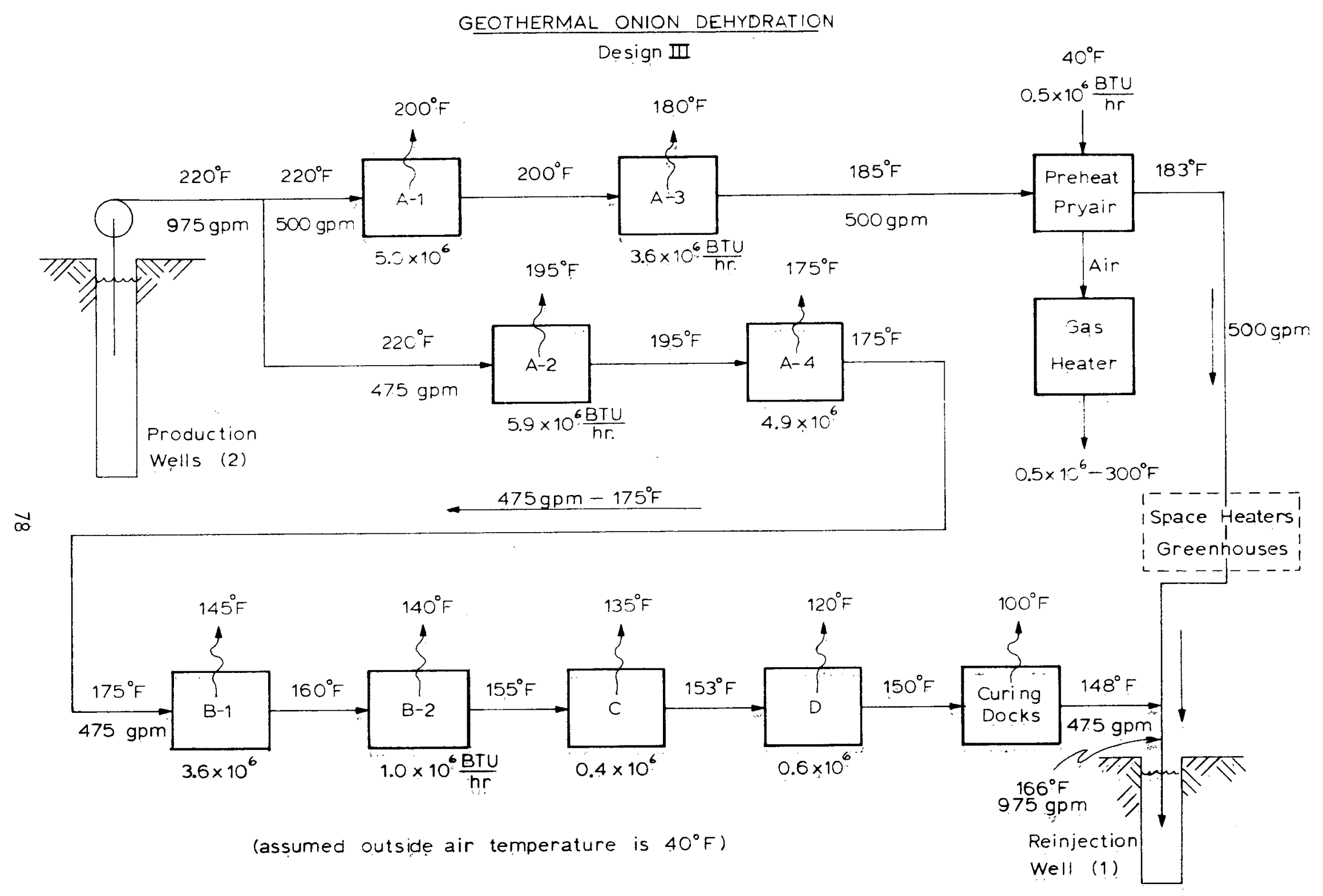

Figure 30. Design III--Single-Line Onion Dehydrator Using $220^{\circ} \mathrm{F}$ Geothermal Water. and $40^{\circ} \mathrm{F}$ Ambient Air. 
LAYOUT

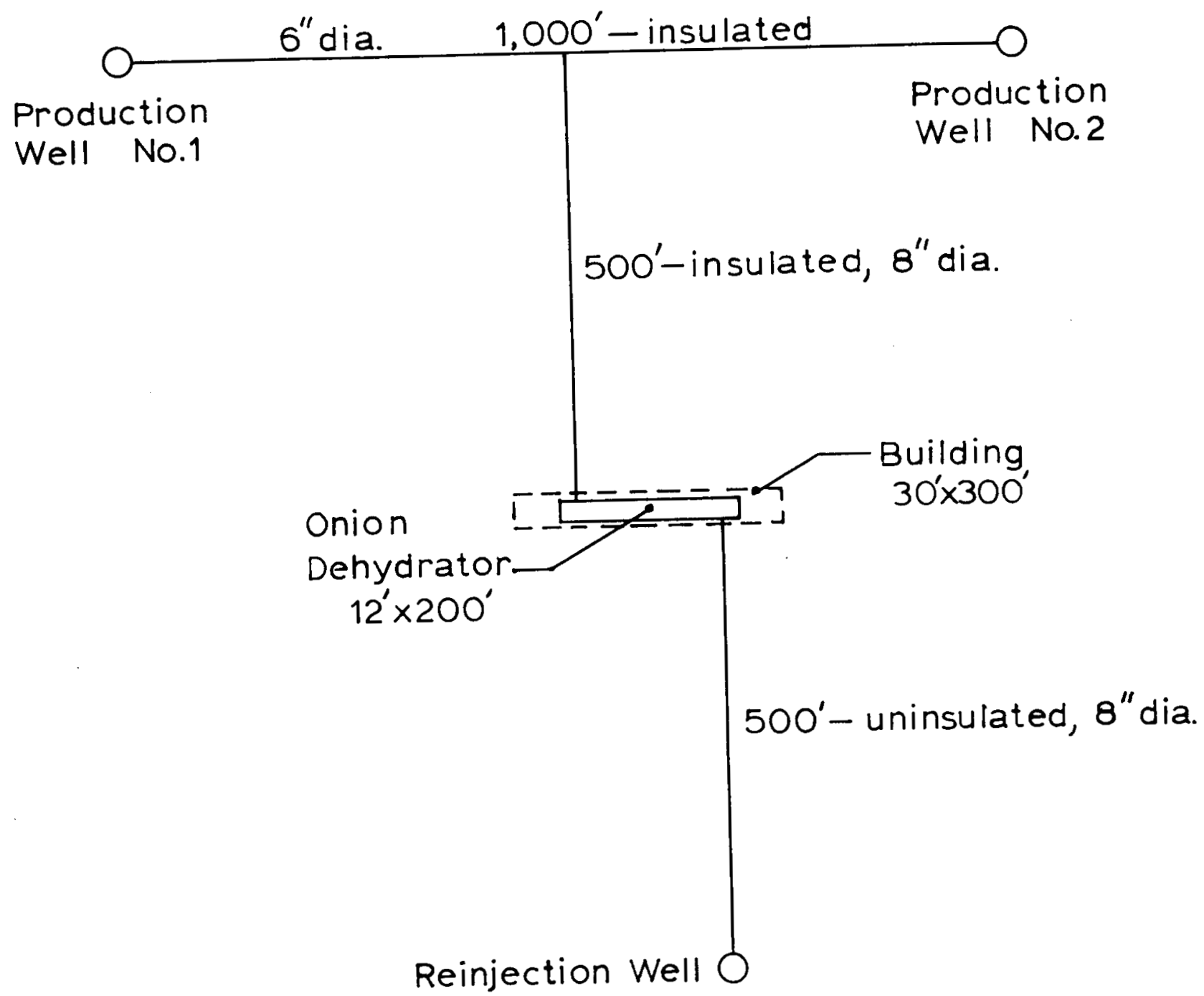

Figure 31. Single-Line Onion Dehydrator Layout of Plant and Wells. 
If lower-temperature geothermal waters were encountered (below $200^{\circ} \mathrm{F}$ ), then not all of the energy could be supplied to Stage A geothermal1y. Geothermal water would then be used as a preheater, with natural gas providing the energy for the final temperature rise. A design of this type for compartment A-1 was considered in the Trident Report (1977) for the Solar Division of ERDA.

\section{e. Economic Analysis}

The economic analysis of onion dehydration does not consider investment tax credits on tangible costs, tax reduction due to write-off of intangible costs, depletion allowances, or tangible asset depreciation due to the fact that this project involves starting new facilities which could take up to five years to pay back the additional capital investment as compared to conventional systems. It is not known what kind of ownership or the tax structure that would be involved, nor what method of depreciation would be appropriate. Therefore, the analysis is ultraconservative and all federal tax incentives for capital investment and use of geothermal energy would increase the profit margins considerably over these figures.

Since there currentiy are no onion dehydration plants in the Klamath Basin, the cost analys is for an onion dehydration plant was done by investigating the cost difference in establishing a dehydration plant using conventional fuel (natural gas) versus geothermal energy.

The cost of capital was established at 9 percent per annum and project 1 ife was estimated at 20 years. Maintenance costs are expected to increase at 6 percent annually. Electrical power costs are projected to inflate at 8.5 percent per annum through 1986 and at 7.58 percent thereafter. Natural gas costs are projected to increase at 11.2 percent per annum through 1986 and 7.5 percent thereafter. Using the annual equivalent cost formula for inflation with the above assumed inflation rates (Oregon Department of Energy, 1977), the following were calculated:

1. 20-year annual equivalent for $\$ 1$ of maintenance cost $=\$ 1.56$

2. 20-year annual equivalent for $\$ 1$ of electric power cost $=\$ 1.87$

3. 20-year annual equivalent for $\$ 1$ of natural gas cost $=\$ 2.18$ 
Break-even analysis indicates that a dehydration plant would have to operate 180 hours per year in order to make the geothermal system competitive with natural gas. The onion harvest season in the Klamath Basin is approximately two weeks. Assuming a two-week processing supply of onions, 24-hour operation for 14 days would be 336 hours of operation annually which would provide a $\$ 31,454$ advantage to the geothermal system. Storage facilities could extend the processing period greatly and starting sets in greenhouses would provide an even longer processing season. It should be noted that the return fluid is very suitable for a large 15-acre greenhouse complex, as described in this report under Section IV -5 .

TABLE IV

Onion Dehydration Plant

Estimated Capital Costs for Geothermal System

20-year annual equivalent cost a $9 \%$

Heat exchangers

Piping $2000^{\prime}$ a $\$ 5 / \mathrm{ft}$

Valves and fittings

Instrumentation

Electrical wiring

Design modification--engineering

2 production wells $2000^{\prime}$ a $\$ 51,500 /$ we 11

$6 "$ insulated pipe 1000' a $\$ 16 / \mathrm{ft}$

$8^{\prime \prime}$ insulated pipe $500 \mathrm{ft}$ a $\$ 23.50 / \mathrm{ft}$

8" uninsulated pipe $500 \mathrm{ft}$ \& $\$ 9.50 / \mathrm{ft}$

1 return we11 $1.000^{\prime}$

2 deep we11 pumps $60 \mathrm{hp} \$ 15,000$ each
$\$ 50,000$

10,000

5,000

5,000

5,000

5,000

$\$ 80,000$

$\$ 8,763.72$

$\$ 103,000$

16,000

11,800

5,000

26,000

30,000

$\$ 191,800$

$\$ 21,011.01$

\section{Annual Costs}

Cleaning and adjustment of heat exchangers

Replacement parts and labor

Pump/line/we 11 maintenance

$\$ 2,000$

3,500

2,500

$\$ 8,000$

$\$ 12,480$

Total Annual Equivalent Fixed Costs 
Annual Energy Costs (variable)

Electrical energy for pumps

$2-60 \mathrm{hp} 80 \%$ efficient $=\frac{150 \mathrm{hp}}{1.341}$

$112 \mathrm{KWh}$ @ $.01085 / \mathrm{KWh}=$

$\$ 1.2136$

$\$ 3.702$

Natural gas for Bryair

1.10

4.037

Total 20-Year Annual Equivalent Costs

$\$ 7.739 / \mathrm{hr}$

Total Annual Equivalent Costs $=42,255+\$ 7.74 / \mathrm{hr}$

\section{Capital Costs for Conventional System}

Cost of natural gas system and boilers

Cleaning and adjustment of natural gas boilers

Replacement of natural gas parts

$\$ 10,000$

2,000

1,000

20-year annual equivalent cost (e) $9 \%$

Total annual equivalent fixed costs $\$ 1,095$ 3,120

1,560

Annual Energy Costs (variable)

$26 \times 10^{6} \mathrm{BTU} / \mathrm{hr}$ \% $.22 /$ therm $90 \%$ efficiency 57.20

$\$ 5,775$

Total annual equivalent costs $\$ 5,775+\$ 210 / h r$

Using these costs, the break-even point can be found in annual hours of operation.

Difference in fixed cost:

$\$ 42,255-\$ 5,775=\$ 36,480$ higher for geothermal

Contribution per hour of geothermal system:

$\$ 209.924-7.739=202.185 / \mathrm{hr}$

Break-even occurs at $\frac{\$ 36,480}{202.185}=180.43 \mathrm{hrs}$ 


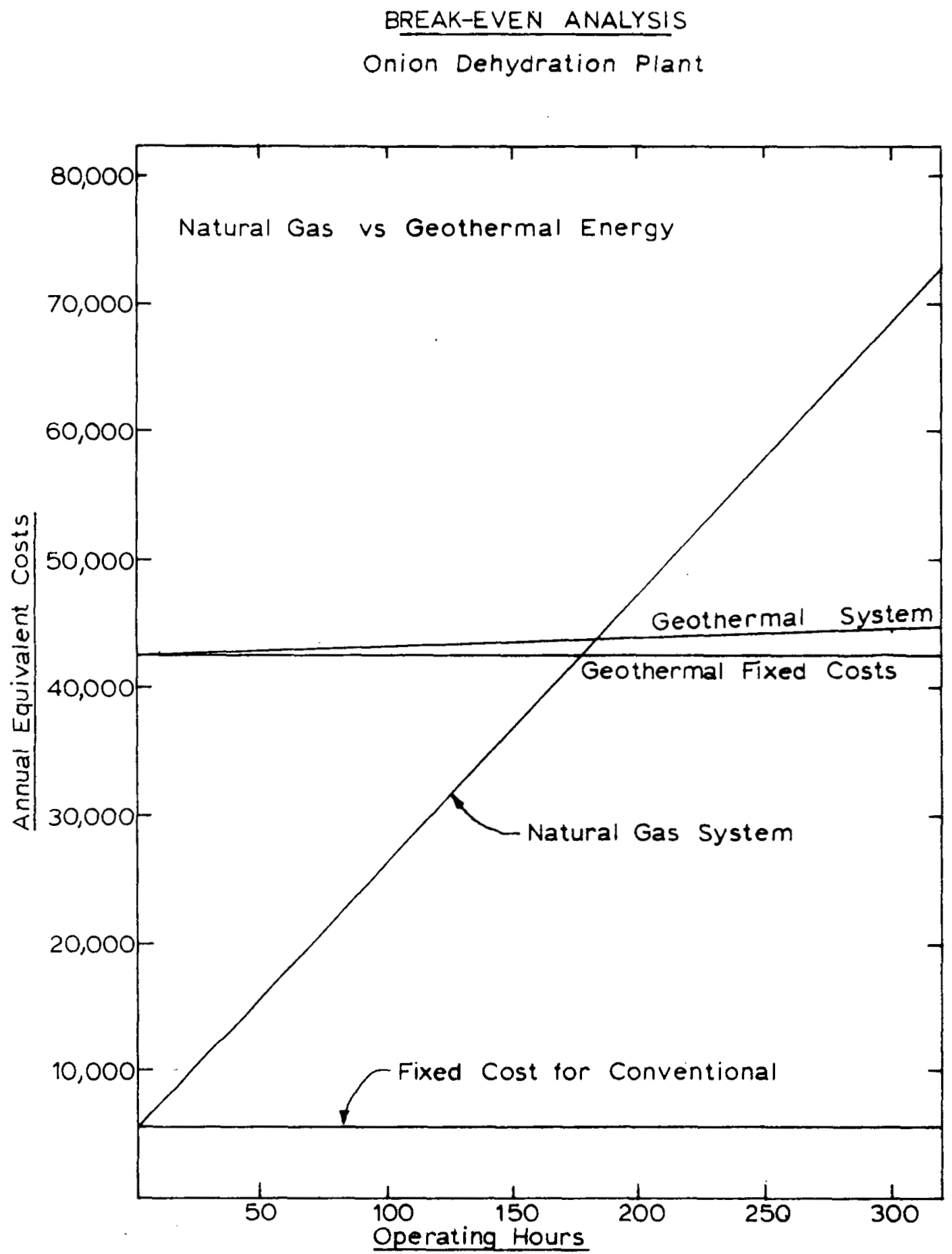

Figure 32. Onion Dehydration Plant Break-Even Analysis for Operating Hours. 


\section{Alfalfa Dehydration}

\section{a. General Description}

A total of $1,386,000$ tons of alfalfa hay were produced in Oregon in 1976. Approximately 70 percent of this production is used within the state. The largest domestic market is California. A survey indicates that approximately 10 to 15 percent of the alfalfa hay is cubed or pelletized. Alfalfa cubes and pellet exports in 1976 amounted to 25,112 tons, at an average price of approximately $\$ 100 /$ ton. Exports to Japan amounted to over 99 percent of the total.

Most pelletizing includes a mixture of alfalfa, grass and oat hay, as well as additives of molasses and other food supplements. The $\mathrm{Klamath} B$ asin has a three-month season (three cuttings) from mid-June to late September. Approximately 45,000 acres are in production producing about 4-1/2 tons per acre or 202,500 tons total per year. Approximately half of the amount goes to dairies for feed over the winter and the majority of the other half is shipped out of the Basin (at about $\$ 20$ per ton for transportation). The alfalfa is normally field (sun) dried to about 10 percent moisture and sold for $\$ 55$ to $\$ 75$ per ton. Klamath Falls has a small pellet mill and Alturas, California, has a cuber. However, neither requires heat for drying the product, as it is all field (sun) dried. The Boardman area of Northern Oregon is a large producer and processor of alfalfa. Two basic products are made from the dehydrated alfalfa: pellets and cubes. The cubes are about $1-1 / 2$ inches $\times 1-1 / 2$ inches $\times 3$ inches 1 ong. Cube production generally only requires field (sun) drying to about 17 to 19 percent moisture (first cutting seven to eight days drying, second and third about 48 hours, and fourth cutting about five to six days--in the Boardman area). During production the cubes generate heat and must be cooled at the end of the production cycle. When used as feed, the cubes do not require the addition of ruffage. The pellets are about $1 / 4$ inch in diameter by $1 / 2$ inch to 1 inch 1 ong and they require significant quantities of heat for dehydration at a plant. They require about $1 \times 10^{7}$ BTU per ton of dried product or $2 \times$ $10^{6}$ BTU per ton of wet product in the process. When used as feed, the addition of ruffage is necessary--costing about the same as the pellets. Unfortunately, pellet production is very competitive and no new plants are being built in areas where sun drying is possible. The cube market is not as competitive.

Two different types of dehydration plants are known. The first, a rotary flame furnace used in the United States, requires temperatures up to $1800^{\circ} \mathrm{F}$, and the other, used in New Zealand, is a forced air system using a multi-layer conveyor belt with temperatures up to $250^{\circ} \mathrm{F}$. In both cases, it takes about $10,000 \mathrm{lbs}$ of wet alfalfa to produce 2,000 lbs of finished product. 


\section{(1) California High-Temperature Plant}

A large alfalfa dehydration plant in Sacramento Valley, California, was visited in May of 1977 . This plant will produce 10,000 tons of finished pellets this year $(30,000$ tons reported in previous years) consisting of both alfalfa and brewers grain waste from a nearby brewery. The pe1lets are $1 / 4$ inch in diameter by 1 inch long produced from alfalfa at an initial moisture content of 77-82 percent and with a final moisture content of 10 percent.

A Sterns-Rogers single-pass rotary dryer is used, evaporating 60,000 to 65,000 pounds of dry product per hour with a 100 million BTU/hr natural gas burners. Thus, this requires about 0.16 therms per pound of dry product.

The main advantage of this process over sun curing is that more vitamin $A$ and xanthrophyll (a yellow pigment present in the normal chlorophy 11 mixture of green plants) is retained. The latter is important in chicken and egg coloring. The xanthrophyll is retained better by high heat and rapid dehydration.

The normal operating season is from mid-March to midNovember and requires 25 people. Year-around operation is achieved by using the brewers grain waste. The buying area for the grain is 20 miles, as the plant cannot afford to haul "water" greater distances. Half of the final pellet cost is due to the dehydration cost.

\section{(2) New Zealand Low-Temperature Plant}

The system used in New Zealand at Broadlands is the result of a cooperative of. 12 farms in the area, formed in 1973. Over a three-year trial period the system has proved successful and up to May, 1977, some 3,000 tons of dried alfalfa pellets have been produced.

In general, geothermal steam from a deep well bore in the Broadlands geothermal field is used. The steam is produced via a separator and used in a heat exchanger system to produce a hot air stream of approximately $275^{\circ} \mathrm{F}$. The plant uses 16,000 pounds of steam per ton of pellets. A simple fixed bed, double-pass dryer is used. This dryer is made by the company and the system is unique. A continuous operation extracts approximately 8,000 pounds of moisture per hour giving approximately one ton per hour of dried alfalfa per drying unit. A larger 1-1/2 ton per hour unit is at present being developed. The system can be used for all types of green feed and grains and should also be suitable for wood chips, etc. The alfalfa pellets 
produced are of high quality, strong green in color and exceed international specifications for alfalfa products. They are completely free of any type of contaminant, the material being dried in hot fresh air at all stages.

The alfalfa (lucerne) grown by farmers in the area surrounding the plant is chaffed and blown directly into trucks and delivered to and loaded onto the dryer elevator at moistures ranging between 70 and 85 percent. The drying cycle takes approximately $1 / 2$ hour and the dried material being auger discharged into a hammer mi11. It is then transported to the pellet press where it is compressed into pellets for storage and transport. Labor in the plant is minimal, two men being able to operate the entire process excluding harvesting. A plant to produce 3 tons of pellets per hour would cost $\$ 500,000$ and would require 3,000 acres of alfalfa to keep the plant working at full capacity. Working 4,000 production hours per year would produce 10,000 tons of pellets.

(3) Boardman, Oregon, Low-Temperature Plant

A new method of dehydration has been used in the Boardman area in northern Oregon. This involves wilting the product in the field to remove about 25 percent moisture. The balance of the moisture is then removed by dehydration at the plant in order to retain as much of the nutrient value (vitamin A) as possible. This process requires temperatures from $180^{\circ}$ to $250^{\circ} \mathrm{F}$.

There are several reasons for fuel drying on the final product instead of complete sun wilting. Fuel drying produces a harder and heavier pellet, and retains a greater percentage of the vitamin $A$ and xanthrophy 11.

Ideally, 100,000 to 125,000 international units of vitamin $A$ and xanthrophyl1 are needed; however, this can only be achieved by complete fuel drying as described in the California plant. By field wilting and then some fuel drying, they can retain a minimum of 17 percent protein and an average of 55,000 international units of vitamin $A$ (xanthrophyli is assumed to be at about the same level as vitamin A). In addition, a bright green color is maintained that appears to improve the sellability of the product. The Japanese feel the protein guarantee is important. Complete dehydration at this time does not appear to be economical and no new plants are being built along this line. 
The domestic market uses pellets for a feed mix. The main advantage with the process at Boardman is:

(a) Low fuel and temperature requirements

(b) High field moisture loss

(c) A final product with a bright green color

(d). An average of 55,000 international units of vitamin $A$ (xanthrophyll assumed to be at the same level)

(e) A minimum of 17 percent protein

A plant of this type will produce 80 to 110 tons of pellets per eight-hour shift (ten tons per hour average--16 to 17 tons maximum). The alfalfa is purchased (or costs the company) at $\$ 45$ to $\$ 55$ per ton standing (at 12 percent moisture), and costs an additional $\$ 20$ per ton to harvest and pellet. Of the total cost $\$ 2.50$ is due to the actual drying or about 6 gallons of fuel oil per ton of alfalfa (at $\$ .40$ per gallon). This fuel usage can range from 5 to 30 gallons per ton depending upon the moisture content and the ambient conditions. The total cost of pellets is $\$ 65$ to $\$ 75$ per ton, of which about $\$ 5$ per ton is the margin of profit. Thus any fuel savings by converting to geothermal would have a significant percentage effect on the margin of profit.

The main disadvantage with this process is that it does not produce any ruffage or fiber. Cubing will provide the necessary fiber, otherwise the pellets must be combined with ruffage for domestic use. Cost of construction of a pellet plant today is around $\$ 1$ million, whereas a stationary cubing plant would cost $\$ 200,000$ and a field cubing plant about $\$ 50,000$.

\section{b. Processing Steps}

The more typical high-temperature plant, such as the one in California, would have the following processing steps (see Figure 33):

The alfalfa is cut in the field and chopped to lengths of $3 / 4$ to $1-1 / 2$ inches long ( $1-1 / 2$ to 3 inches long for cubes). It is then trucked into the plant and dumped on an outdoor storage slab. From there the material is transferred by front loader to a bin and volumetric feeder. The feed rate for the entire plant is controlled at this point. A conveyor belt lifts the alfalfa to the rotary drum dryer. This dryer is 48 feet long and 10.5 feet in diameter. The drying heat is provided by a series of nozzles providing gas burning throughout the length of the drum. The drum is tilted and rotates so that the heat, air and time in the dryer produces the desired final moisture content. Typical retention time is 20 minutes. Throat temperature is $1800^{\circ} \mathrm{F}$ and exit temperature $235^{\circ}$ to $240^{\circ} \mathrm{F}$. The 


\section{PELLETIZED ALFALFA PROCESSING}

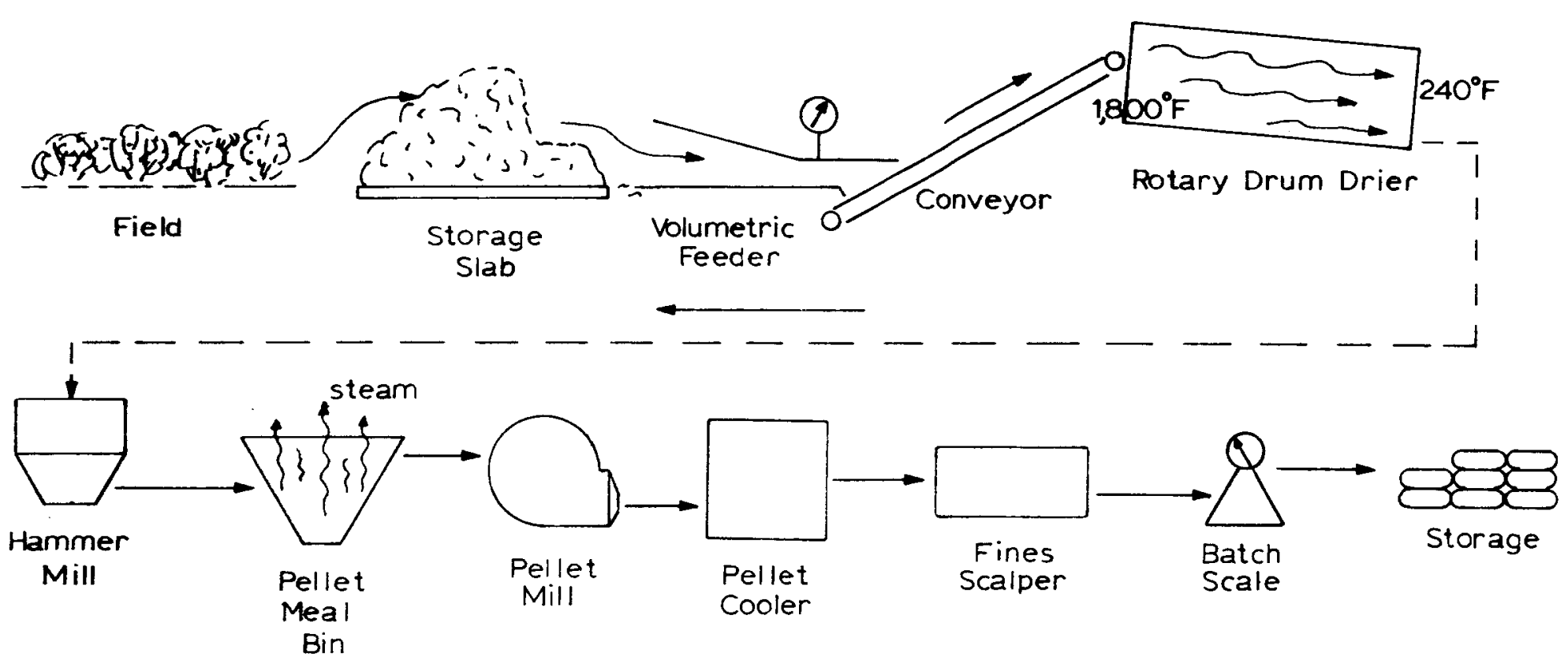

Fiqure 33. Pelletized Alfalfa Processing Steps. 
stack exit temperature is $215^{\circ} \mathrm{F}$. The dryer is considered a single-pass, high-moisture product dryer with perforated hot plates and a detention chamber for the heavier and wetter particles. Ideal entering moisture content is 70 percent or less.

From the dryer, the alfalfa is fed to the hammer mill and the pellet meal bin. The latter is the surge point in the system. Here the material is conditioned with 17 pounds per ton of 35 psi production steam and then fed to the pellet mill pressure extruder. The steam helps in providing a uniform product and makes it easier to extrude the alfalfa through the 1/4inch diameter holes in the circular steel plates. The material is then cooled and the fines removed in a scalper. Finally, the product is weighed on batch scales, packaged and stored.

The processing steps for the plant as described for the Boardman area are somewhat unique in the West, as it involves field wilting and a final dehydration in a rotary drum dryer. This process is also being attempted in the Midwest. Approximately 25,000 to 30,000 tons of alfalfa pellets (at 8 to 15 percent moisture) can be produced each year at 8 tons per acre (at 8 percent moisture). This assumes four to five cuttings per year. It should be pointed out that the Boardman area has extremely dry and hot summers with little or no rain, thus making field wilting practical.

The process starts with cutting and chopping the alfalfa in the field at about 70 percent initial moisture. The chopped material is then allowed to sun wilt for 24 to 48 hours to a 15 to 25 percent moisture content. This can easily be accomplished in the Boardman area due to available sun and low rainfall (if any) during the season. The Midwest is only able to wilt to about 60 percent moisture. This short field wilting time also prevents minimal damage to the next crop, as the cut material is removed before the new shoots sprout and are crushed by equipment. The field wilted material is then trucked to the plant (generally a short distance as they cannot afford to haul "water"), and stockpiled for no more than a couple of days. The chopped material is then belt-fed to a triple-pass rotary drum dryer. This dryer initially used natural gas for fuel, but this has been cut off so they now use fuel oil. The alfalfa is dried at a temperature below $250^{\circ} \mathrm{F}$, as any temperature over $400^{\circ} \mathrm{F}$ will over-dry the product. The actual drying temperature depends upon the ambient conditions and moisture content of the alfalfa. The final pellets are checked for firmness, color, etc., as a means of adjusting the plant. Dryer temperatures can go as low as $180^{\circ} \mathrm{F}$, and on some warm days the outside air can produce temperatures of $150^{\circ}$ to $160^{\circ} \mathrm{F}$ without fuel. The material is moved through the dryer by a suction fan capable of producing $50,000 \mathrm{cfm}$ (25 percent of this air is recycled). The retention time is about 15 to 20 minutes. The material is then fed through 
a process similar to the one described for the California plant. The only other heat enerqy required is in the steam curing at the pellet mill--this provides a binder for the pellets. The final product is bulk stored and most of it shipped to Japan for its protein content.

\section{c. Geothermal Conversion}

Geothermal Applications--It is estimated that approximately half $(72,000$ tons) of the alfalfa product in the Klamath Basin could be converted to cubes or pellets for use as dairy cattle feed. Geothermal energy might make it economical to start such a plant in the Basin, especially since more and more alfal$\mathrm{fa}$ is being raised. If a plant were considered for this area, one using the lower temperature heat (New Zealand- or Boardmantype) would probably be the most reasonable, as this temperature is closest to the temperature of the local resource. It is questionable whether it would be economically feasible to increase the temperature of the resource by conventional fuel to meet the temperature demands of the California-type rotary flame furnace plant.

A geothermal energy conversion design was made for the Boardmantype plant, as not enough details were available for the New Zealand-type. However, since the temperatures for both are similar, a design for the New Zealand-type using geothermal water instead of steam is possible.

Using a $200^{\circ} \mathrm{F}$ air drying temperature for the triple-pass dryer would require at least $220^{\circ} \mathrm{F}$ geothermal water. This temperature water is available in the Klamath Basin; however, wells up to 1,500 feet deep would probably be necessary.

Assuming a combination of ambient air and 25 percent recycle air at $75^{\circ} \mathrm{F}$ and 50,000 cubic feet per minute, $6.8 \times 10^{6} \mathrm{BTU} / \mathrm{hr}$ would be required.

If on $1 y 200^{\circ} \mathrm{F}$ water were available, then $180^{\circ} \mathrm{F}$ air could be used requiring $6.3 \times 10^{6} \mathrm{BTU} / \mathrm{hr}$.

The following combinations of flow rates and temperatures could be used to provide the necessary energy.

$\begin{array}{ccc}\begin{array}{c}\mathrm{T}_{1} \\ \begin{array}{c}\text { geothermal water } \\ \text { incoming }{ }^{\circ} \mathrm{F} \text { ) }\end{array}\end{array} & \begin{array}{c}\mathrm{F}_{1} \\ \text { (Geothermal water } \\ \text { flow gpm) }\end{array} & \begin{array}{c}\mathrm{T}_{2} \\ \text { (Waste geothermal } \\ \text { water temperature) }\end{array} \\ 220^{\circ} & 500 & 193 \\ 220^{\circ} & 300 & 175 \\ 200^{\circ} & 500 & 175 \\ 200^{\circ} & 300 & 158\end{array}$


One well could then provide the required flow, with one injection well for the waste water. The assumed layout of the plant and wells are shown in Figure 34 . Due to the high energy requirements and flow rates, a four-pass fixed water-to-air heat exchanger would be required.

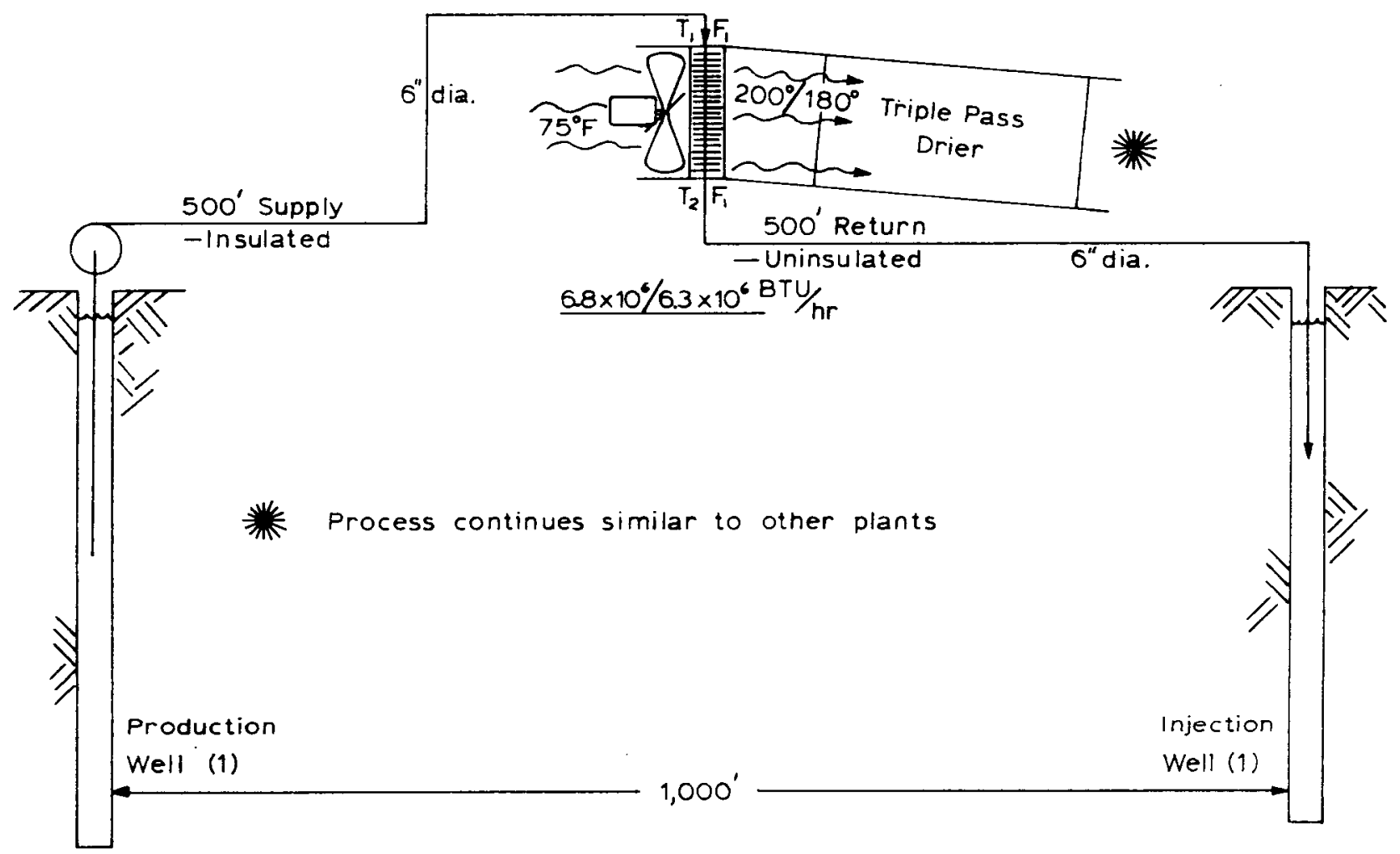

Figure 34. Alfalfa Drying Plant and Well Layout.

Figure 34. Alfalfa Drying Plant and Well Layout. 


\section{d. Economic Analysis}

Economic comparison of a geothermal alfalfa dryina plant as compared to a fuel oil fired plant indicates the capital investment in the heating system is about 60 times higher for geothermal.

The economic analyses of alfalfa drying does not consider investment tax credits on tangible costs, tax reduction due to write-off of tangible costs, depletion allowances, or tanqible asset depreciation due to the fact that these projects involve starting new facilities which could take up to five years to pay back the additional capital investment as compared to conventional systems. Therefore, it is not known what kind of ownership or the tax structure that would be involved, nor what method of depreciation would be appropriate. Therefore, the analysis is ultraconservative and all federal tax incentives for capital investment and use of geothermal energy would increase the profit margins considerably over these figures.

The economic assessment was accomplished using a 20-year 1 ife, 9 percent per annum cost of capital and a 20-vear annual equivalent cost using inflation factors on electric power costs and fuel oil costs as projected by the Oregon Department of Energy. The facility uses a low-temperature dryer of the type similar to that used by a processor in the Boardman, Oregon, area. Annual equivalent fixed costs for the geothermal system are $\$ 16,583$ and require 362 hours of operation annually in order to break even with a fuel oil fired system. A plant of this type produces about 10.33 tons of product per hour and the breakeven point would occur at 3,737 tons annually. Current costs per ton of product are $\$ 50 /$ ton for materials and $\$ 20 /$ ton harvesting and processing. Profit margin per ton of product is $\$ 5$ or 7 percent. By using geothermal energy, the harvesting and process costs would be cut to less than $\$ 16 /$ ton providing a 13.6 percent profit margin per ton of product. These calculations are based on 20-year annual equivalent costs and consider only the variable costs associated with product output. The facility at Boardman has an annual output of between 25,000 and 30,000 tons of pellets annually. After subtracting the increased annual equivalent costs of $\$ 16,364$ for geothermal energy, profits would be increased by over $\$ 100,000 /$ year for such a facility. It must be remembered that these figures are based on a 20-year life and the annual equivalent cost of fuel oil over this 20-year period. At today's prices for energy, considering a 20-year plant life, the break-even point would be 8,000 tons of product annua $11 y$.

Table $V$ indicates that a plant producing 10,000 tons annually would require five years of operation to pay back the capital investment costs of a geothermal system at 9 percent per annum. A plant similar to the Boardman facility would have a payback of about two 
years. It is interesting to note that the decreasing costs of capital as project life increases, opposed to the increasing costs of maintenance inflating at 6 percent give an optimal project 1 ife of 18 years. This analys is only considers fixed annual costs and ignores the fact that due to inflation of heating fuel prices the contribution per ton of product in the 18th year is $\$ 9.19$ and therefore there is considerable profit to be gained by extending the life of the system well beyond 20 years.

TABLE $V$

Alfalfa Pelletizing Plant

Geothermal System Costs

Heat exchanger $\left(425 \mathrm{ft}^{2}\right)$

Fan (100 hp)

Support and housing for fan and heat exchanger Wiring and controls

Contingency $10 \%$

20-year annual equivalent cost (d) $9 \%$

One production well a $1500^{\prime}$

One return well a $500^{\prime}$

$500^{\prime}$ of $6^{\prime \prime}$ insulated pipe

$500^{\prime}$ of $6^{\prime \prime}$ uninsulated pipe

One 60-hp deep well pump

Controls and wiring

Contingency $10 \%$

Geothermal annual fixed costs Maintenance

Geothermal hourly operation costs

Pumping costs $60 \mathrm{hp} \times .7457=56 \mathrm{KWh}$ .80 efficiency

Fan operation $100 \mathrm{hp} \times .7457=83 \mathrm{KWh}$ .90 efficiency
$\$ 15,000$

2,000

5,000

2,000

2,400

$\$ 26,400$

$\$ 2,892$

40,000

15,000

8,000

2,000

15,000

5,000

8,500

$\$ 96,500$

$\$ 10,571$

$\$ 2,000 \quad \$ 3,120$

$\$ 0.6075 / \mathrm{hr} \quad \$ 1.8529 / \mathrm{hr}$

$\$ 0.90055 / \mathrm{hr} \$ 2.7467 / \mathrm{hr}$

$\$ 4.5996 / \mathrm{hr}$ 


\section{0il-Fired System}

Burners and supports

$\$ 2,000 \quad \$ \quad 219$

Annual Costs

Blower operation $75 \mathrm{hp} \times .7457=62 \mathrm{KWh}$ .90 efficiency

$\$ 0.6742 / \mathrm{hr} \quad \$ 2.056 / \mathrm{hr}$

Fuel oil $8.5 \times 10^{6} \mathrm{BTU} / \mathrm{hr}=62 \mathrm{gal} / \mathrm{hr}=27.032 / \mathrm{hr}$

$\$ 47.7925 / \mathrm{hr}$

$\$ 49.849 / \mathrm{hr}$

Total fixed annual equivalent costs geothermal

Plant conversion

Wells, pumps, transmission line

Maintenance
$\$ 2,892$

10,571

3,120

$\$ 16,583$

Break-even in hours of operation

hrs $=\frac{\$ 16,583-\$ 219}{\$ 49.849-\$ 4.5996}=\frac{\$ 16,364}{\$ 45.249}=362$ hours 
TABLE VI

Break-Even in Tons of Product Versus Project Life

\begin{tabular}{|c|c|c|c|c|c|c|}
\hline Year & $\begin{array}{l}\text { Annual cost } \\
\text { of capital } \\
\text { investment } \\
09 \% \\
\end{array}$ & $\begin{array}{c}\text { Maintenance } \\
\text { inflating } \\
\text { a } 6 \% \\
\end{array}$ & $\begin{array}{l}\text { Total } \\
\text { annual } \\
\text { cost } \\
\end{array}$ & $\begin{array}{c}\text { Geothermal } \\
\text { contribution } \\
\text { per ton of } \\
\text { product } \\
\end{array}$ & $\begin{array}{l}\text { Break-even } \\
\text { point in tons } \\
\text { of product } \\
\end{array}$ & $\begin{array}{l}\text { Project } \\
1 \text { ife in } \\
\text { years }\end{array}$ \\
\hline $\begin{array}{l}1978 \\
1979 \\
1980 \\
1981 \\
1982 \\
1983 \\
1984 \\
1985 \\
1986 \\
1987 \\
1988 \\
1989 \\
1990 \\
1991 \\
1992 \\
1993 \\
1994 \\
1995 \\
1996 \\
1997\end{array}$ & $\begin{array}{r}\$ 135,961 \\
69,865 \\
48,552 \\
37,935 \\
30,597 \\
27,397 \\
24,419 \\
22,205 \\
20,500 \\
19,150 \\
18,060 \\
17,163 \\
16,415 \\
15,784 \\
15,247 \\
14,785 \\
14,385 \\
14,037 \\
13,732 \\
13,463\end{array}$ & $\begin{array}{r}\$ 2,120 \\
2,247 \\
2,382 \\
2,525 \\
2,676 \\
2,837 \\
3,007 \\
3,188 \\
3,379 \\
3,582 \\
3,797 \\
4,024 \\
4,266 \\
4,522 \\
4,793 \\
5,081 \\
5,386 \\
5,709 \\
6,051 \\
6,414\end{array}$ & $\begin{array}{r}\$ 138,081 \\
72,112 \\
50,934 \\
40,460 \\
33,273 \\
30,234 \\
27,426 \\
25,393 \\
23,879 \\
22,732 \\
21,857 \\
21,187 \\
20,681 \\
20,306 \\
20,040 \\
19,866 \\
19,770 \\
19,746 \\
19,783 \\
19,877\end{array}$ & $\begin{array}{r}\$ 2.18 \\
2.37 \\
2.81 \\
3.05 \\
3.32 \\
3.60 \\
3.90 \\
4.23 \\
4.58 \\
4.95 \\
5.36 \\
5.80 \\
6.26 \\
6.77 \\
7.31 \\
7.88 \\
8.51 \\
9.19 \\
9.91 \\
10.68\end{array}$ & $\begin{array}{r}63,340 \\
30,427 \\
18,126 \\
13,266 \\
10,022 \\
8,398 \\
7,032 \\
6,003 \\
5,214 \\
4,592 \\
3,953 \\
3,653 \\
3,304 \\
3,000 \\
2,741 \\
2,521 \\
2,323 \\
2,149 \\
1,996 \\
1,861\end{array}$ & $\begin{array}{l}1 \\
2 \\
3 \\
4 \\
5 \\
6 \\
7 \\
8 \\
9 \\
10 \\
11 \\
12 \\
13 \\
14 \\
15 \\
16 \\
17 \\
18 \\
19 \\
20\end{array}$ \\
\hline
\end{tabular}




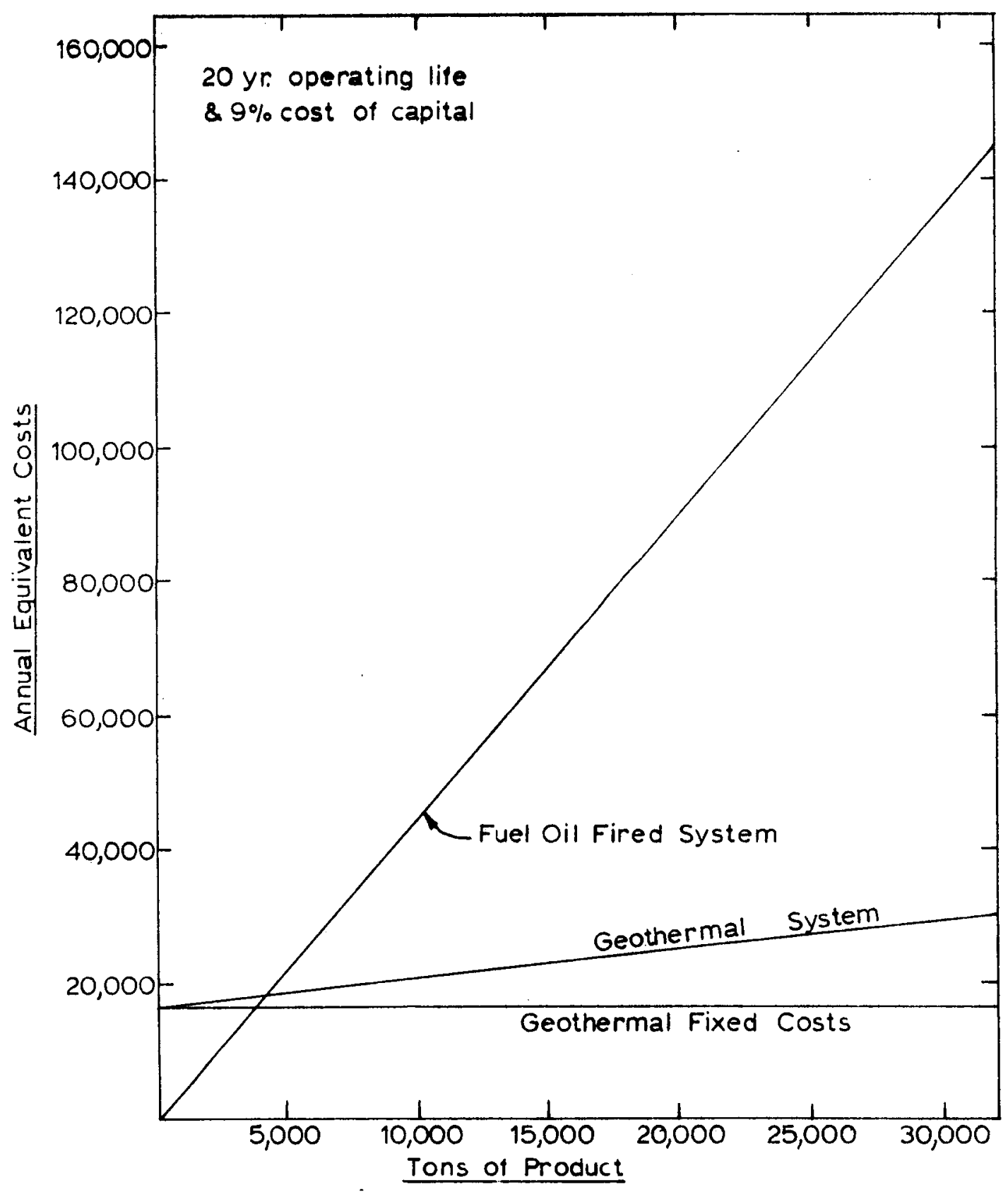

Figure 35. Alfalfa Drying Plant Break-Even Analysis for Tons of Product. 


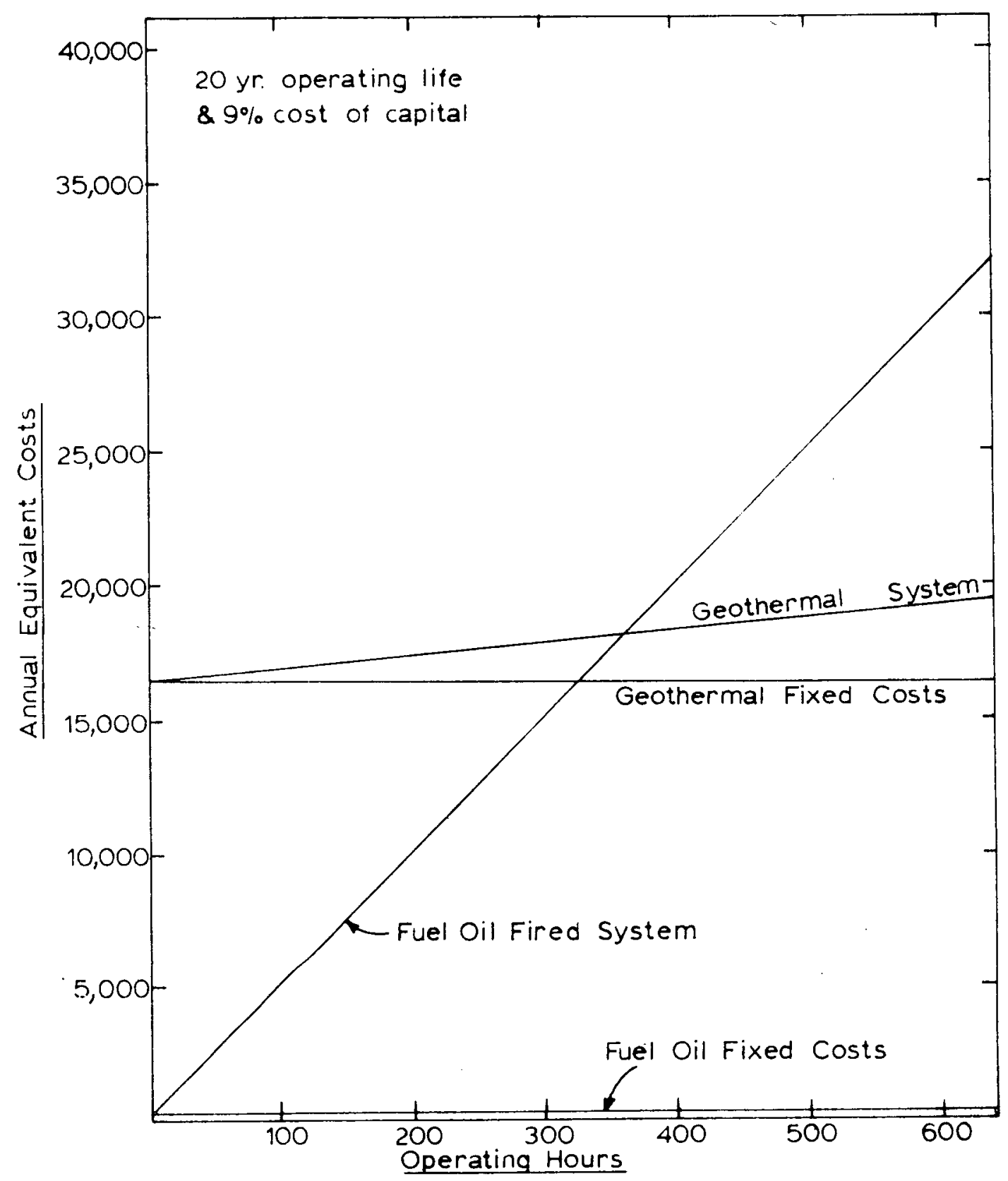

Figure 36. Alfalfa Drying Plant Break-Even Analysis for Operating Hours. 


\section{Western Polymer Corporation}

\section{a. General Description}

The Western Starch Division of Western Polymer Corporation is located on the Oregon-California border, 21 miles south of Klamath Falls.

Twenty thousand acres of potatoes are harvested annually in the Klamath Basin producing 25 to 28 tons per acre. Nearly 10 percent of the potato crop is normally made up of substandard potatoes unsuitable for tablestock market because they are either too small, too large, misshapen, or damaged. Diversion of cull and surplus potatoes to starch factories has done much to improve the quality of tablestock and establish more orderly marketing in the potato industry.

Most of the potatoes grown in the Klamath Basin are sold on the fresh market.

The Western Polymer starch plant processes 14 tons per hour of potatoes (primarily culls) for starch extraction. The operating season or "campaign" is from September to May on an eight-hourper-day basis.

The plant consumes 122,250 gallons of propane annually costing $\$ 42,700$.' Most of the fuel, 85 percent, is used for drying starch to a moisture content of 18 percent. The remaining 15 percent is used for heating offices and the plant area.

Potato starch produced nationwide is used in its various outlets in approximately the following proportions: paper, 60 percent; textiles, 30 percent; food, adhesives, and miscellaneous, 10 percent. Western Polymer's starch is marketed primarily to Campbell Soup and the West Coast paper industry.

\section{b. Processing Steps}

Potatoes are transported from storage to a hammer mi11 by means of a water flume at the rate of 14 tons per hour. The hammer mill is used to disintegrate the potato cells and liberate the starch. The skin and fiber are then separated from the starch.

Starch slurry from the hammer mill flows to centrifugal rotating sieves, which bear some resemblance to a centrifugal pump, but with slotted sieve plates in place of impeller vanes. The pulp slurry enters the rotating sieve through a central feed pipe and then flows radially outward along sieve plates. Centrifugal force drives the starch milk through the slots in the sieve plate. The coarse pulp, which cannot pass through the slots, is discharged 
through a separate outlet. Several centrifugal sieves are usually employed in sieves. An advantage over ordinary screen separation is that the percentage solids content of the waste pulp from the centrifugal sieve is about three times that of pulp from the conventional screen.

The extracted pulp is dried to provide a component for 1 ivestock feed.

The final purification of starch milk is carried out by passage through a battery of cylindroconical centrifugals. These horizontal, continuous centrifugals are used to remove protein water. Settling vats are employed for removing the small quantity of remaining fine fiber and insoluble impurities that settle at the top in the so-called "brown starch" layer. The purified starch is dewatered into a cake form with a 45 percent moisture content by rotary vacuum filters.

Western Polymer uses cyclone "flash" dryers to dry the starch to an 18 percent moisture content. Predrying of the moist starch from the vacuum filter is effected in a screw conveyor through which $250^{\circ} \mathrm{F}$ air passes concurrently heated by direct fired propane burners. The partially dried starch then drops into a high-speed blower where it is mixed with $250^{\circ} \mathrm{F}$ air flowing at $15000 \mathrm{cfm}$. The moisture-laden air and starch are separated in a cyclone dust collector. This is repeated by passing the starch through three additional blowers and cyclone separators. A fifth blower-cyclone cools the starch before bagging. The plant produces three hundred 100-pound bags during an average eight-hour shift.

\section{c. Geothermal Application's}

Geothermal energy from two sources was analyzed: the first from a 3,000-foot deep well located 15,000 feet north of the plant supplying $200^{\circ} \mathrm{F}$ water and the second from an existing 1,200-foot deep well located on the plant site supplying $72^{\circ} \mathrm{F}$ water.

A third option considered drilling the existing well to a depth of 3,000 feet to increase the water temperature to between $180^{\circ}$ to $200^{\circ} \mathrm{F}$.

Option I- $-200^{\circ} \mathrm{F}$ Geothermal Water

The water is pumped from the supply well through an asbestos cement insulated pipeline, passed through close-finned tubed heat exchange coils. The reject water $\left(160^{\circ} \mathrm{F}\right)$ from the heat exchange coils passes through air-handling unit space heaters in the plant, then discharges to an existing cooling tank from which it is used in the process operation of the plant. 
The existing dryer system (Figure 37 ) requires $15,000 \mathrm{cfm}$ air flow from an inlet inside the warehouse estimated at a temperature of $35^{\circ} \mathrm{F}$ during winter operation. The air temperature is raised to $250^{\circ} \mathrm{F}$ by propane burners providing $3.5 \times 10^{6} \mathrm{Btu} / \mathrm{hr}$ to the dryer. A finned-tube heat exchanger installed in the warehouse would serve as a preheater increasing the air temperature from $35^{\circ}$ to $180^{\circ} \mathrm{F}$ with $200^{\circ} \mathrm{F}$ water flowing at $237 \mathrm{gpm}$ on the water side. This heat exchanger would provide $2.4 \times 10^{6} \mathrm{Btu} / \mathrm{hr}$ or 68 percent of the energy requirements for the drying process. Reject water at $180^{\circ} \mathrm{F}$ from the heat exchanger could supply the necessary space heating for the plant, an estimated peak load of $1.0 \times 10^{6} \mathrm{Btu} / \mathrm{hr}$. This system would supply 76 percent of the thermal energy requirements for space and process heat.

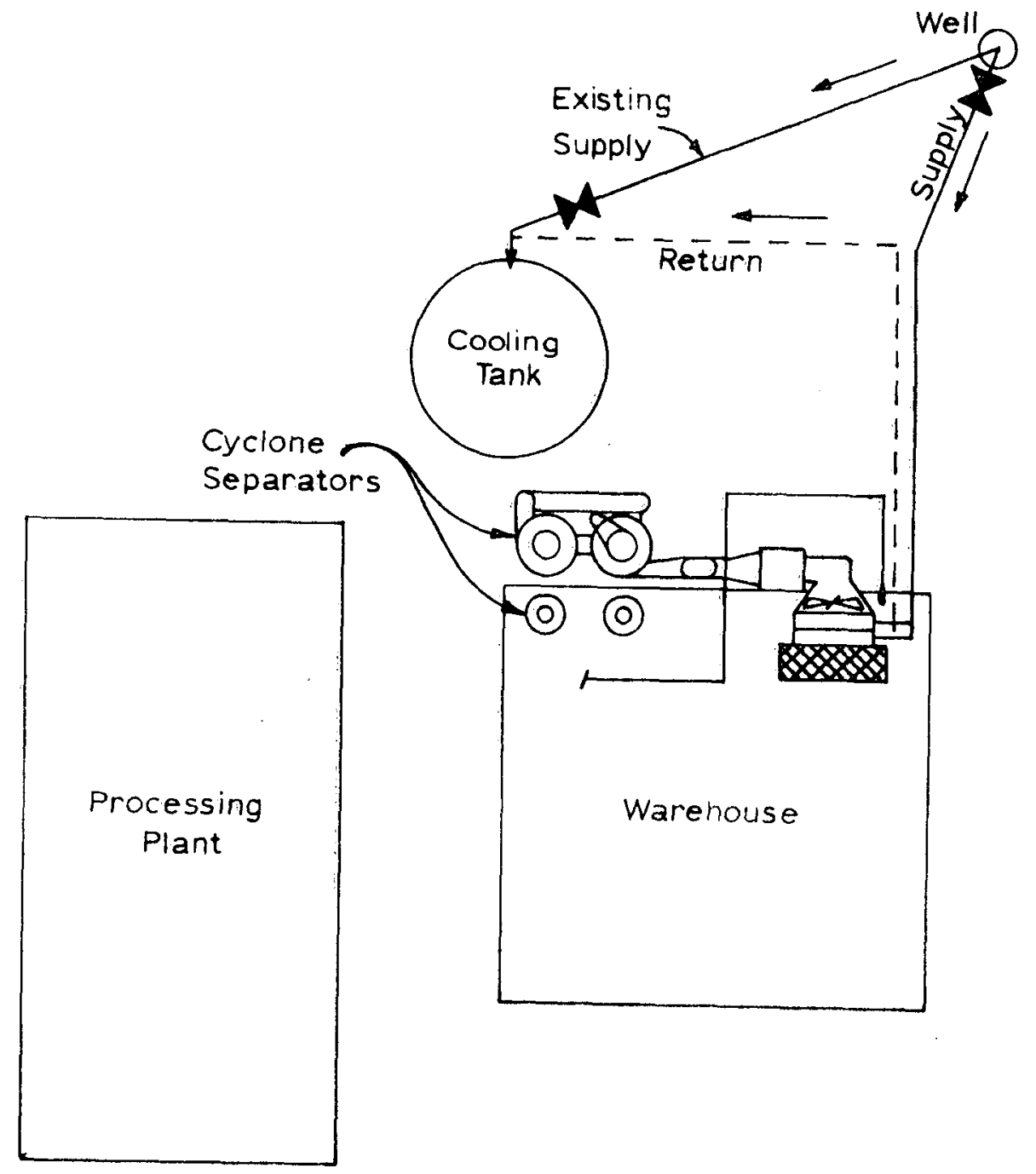

U.S. Highway $139 \quad$ South $\longrightarrow$

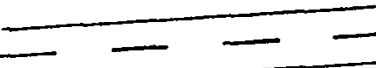

Figure 37. Western Polymer Corporation layout of existing well and transmission 1 ines. 


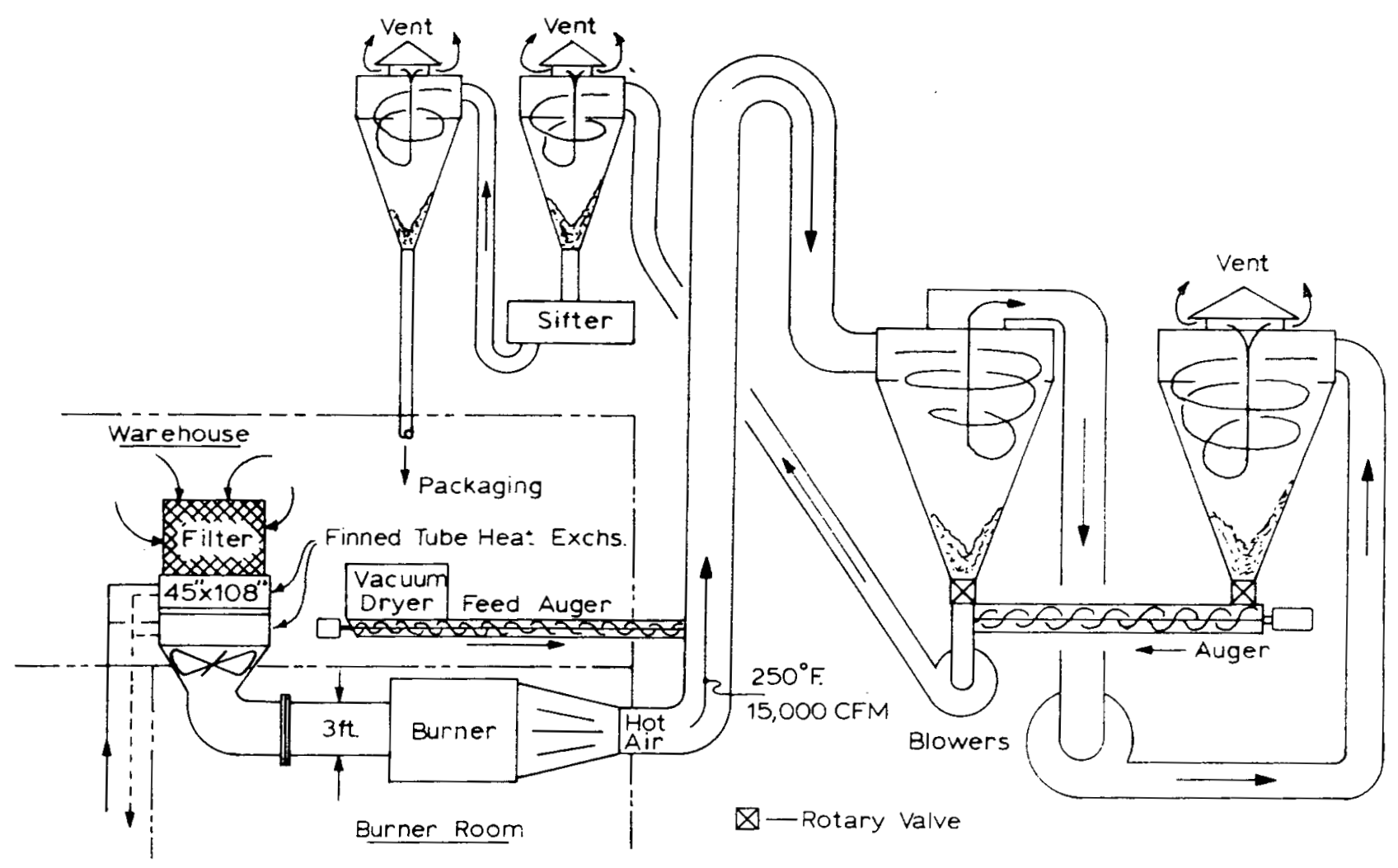

Figure 38. Western Polymer Corporation potato starch dryer.

Option II--72 $\mathrm{F}$ Existing Well

Water at $72^{\circ} \mathrm{F}$ is pumped to a cooling tank where it is cooled to about $62^{\circ} \mathrm{F}$ before it is used in processing starch from potatoes. Starch processing requires about $500 \mathrm{gpm}$ of $62^{\circ} \mathrm{F}$ water in this plant.

Piping $72^{\circ} \mathrm{F}$ water to finned-tube heat exchangers installed at the air inlet of the existing dryer can serve as a preheater, heating the air up to $68^{\circ} \mathrm{F}$ during winter operation. This will supply $540,000 \mathrm{Btu} / \mathrm{hr}$, which represents about 15 percent of the heat required for drying at peak load, or when the entering a ir temperature is $35^{\circ} \mathrm{F}$. 
The existing well has a 40-hp deep-well shaft-driven pump capable of pumping $500 \mathrm{gpm}$ of $72^{\circ} \mathrm{F}$ geothermal water. The pump is controlled by the water level in a cooling tank. This well has been pump-tested up to $2,650 \mathrm{gpm}$.

Approximately 300 feet of asbestos cement buried pipe would be required to supply water to the preheat coil located in the warehouse. If insulated pipe were used, the temperature drop would be $0.06^{\circ} \mathrm{F}$, and $0.6^{\circ} \mathrm{F}$ for bare pipe with a flow of $270 \mathrm{gpm}$.

\section{Option III}

This option considered drilling the existing 1,200-foot well to a depth of 3,000 feet in hopes of encountering $180^{\circ}$ to $200^{\circ} \mathrm{F}$ geothermal water. In addition to supplying preheat for process, this system would also provide space heating of the plant. The components would be the same as Option I except for the 15,000-foot pipeline.

The company should consider measurements of the existing well to determine the feasibility of this approach.

\section{d. Economic Analysis}

The economic analysis for Western Polymer Corporation was completed by considering three options. All of the analyses were based on 200 percent declining balance depreciation with the exception of Table IX, which was completed to show the company the advantages of 200 percent declining balance as compared to 150 percent declining balance. In all cases the inflation rate of propane was calculated on all three options using a 9 percent cost of capital (this is Western Polymer's method of evaluating investment alternatives).

Option I consists of drilling a 3,000-foot well 15,000 feet from the plant site yielding $200^{\circ} \mathrm{F}$ water. Option I requires a total investment of $\$ 406,800$ and would supply 76 percent of the total energy requirements of Western Polymer. By expensing all intangible costs in the first year and applying a 20 percent investment tax credit to the tangible costs, option I provides a present worth of only $\$ 288,867$ without considering additional cost for electricity and maintenance of the geothermal system. Therefore Option I is not economically feasible.

Option II consists of using $72^{\circ} \mathrm{F}$ water from an existing well located at the plant site which would supply 15 percent of the total energy requirements of the company. Option II requires no intangible costs and a total tangible investment of $\$ 15,000$. Two hundred percent declining balance depreciation with ten-year 1 ife and the 20 percent investment tax credit would allow option II to yield an ROI of approximately 37 percent and a four-year payback period. In terms of ROI, or payback period, Option II is by far the most attractive. However, it accomplishes very little in regard to providing an independent energy source for Western Polymer since they would still be 85 percent dependent on propane to meet their energy needs. 
In view of the fact that Option I is too costly and Option II fails to solve the energy problem, option III was considered as a third possibility.

Option III consists of drilling the existing 1,200-foot well 1,800 additional feet to a total depth of 3,000 feet. This option assumes that $200^{\circ} \mathrm{F}$ water could be reached at this depth. The casing size of the existing well is suitable to allow further drilling. It was felt that $200^{\circ} \mathrm{F}$ water could be reached at a depth of 3,000 feet in 0ption I and the temperature gradient in the existing well indicates that approximately $200^{\circ} \mathrm{F}$ water could be reached at a depth of 3,000 feet. The primary advantage of drilling in the existing well would be to eliminate the cost of power lines and water transmission lines. The total first-year cost for Option III is \$61,250 intangible costs and $\$ 63,570$ tangible costs, for a total capital outlay of $\$ 124,820$. The intangible costs would be expensed in the first year, providing a tax reduction of $\$ 29,400$ for a net intangible cost of $\$ 31,850$. An investment tax credit of $\$ 12,714$ in the first year would be available on the tangible costs and with 200 percent declining balance depreciation assuming a ten-year 1 ife and 10 percent or less salvage value this option would providea 26.5 percent ROI and a payback period of slightly less than five years. Option III appears to be the most attractive of the three options considered since it yields an attractive ROI, a shorter payback period than required by Western Polymer Corporation (five years), and reduces the consumption of propane by 76 percent. Installation of heat pumps at a later date could pick up the remaining 24 percent of the company's energy needs.

TABLE VII

WESTERN POLYMER CORPORATION

Fuel Costs

Ten-year projection of fuel costs assuming a 6 percent inflation rate and a propane inflation rate of 1-1/2 percent above the normal inflation rate. Reference: Oregon Department of Energy, "Oregon's Energy Future," First Annual Report, January 1, 1977. Beginning with a December 1977 cost of $\$ .325$ per gallon and an annual consumption of 122,251 gallons.

\begin{tabular}{|c|c|c|c|}
\hline Year & $\begin{array}{c}\text { Projected } \\
\text { Propane Costs }\end{array}$ & $\begin{array}{r}\text { Savings } 76 \% \\
\text { Options I \& III } \\
\end{array}$ & $\begin{array}{c}\text { Savings } 15 \% \\
\text { Option II }\end{array}$ \\
\hline 1978 & $42,711.44$ & $32,460.70$ & $6,406.72$ \\
\hline 1979 & $45,914.80$ & $34,895.25$ & $6,887.22$ \\
\hline 1980 & $49,358.41$ & $37,512.39$ & $7,403.76$ \\
\hline 1981 & $53,060.29$ & $40,325.82$ & $7,959.04$ \\
\hline 1982 & $57,039.81$ & $43,350.26$ & $8,555.97$ \\
\hline 1983 & $61,317.80$ & $46,601.53$ & $9,197.67$ \\
\hline 1984 & $65,916.64$ & $50,096.64$ & $9,887.50$ \\
\hline 1985 & $70,860.38$ & $53,853.89$ & $10,629.06$ \\
\hline 1986 & $70,174.91$ & $57,892.93$ & $11,426.24$ \\
\hline 1987 & $81,888.03$ & $62,234.90$ & $12,283.20$ \\
\hline
\end{tabular}


TABLE VIII

Option I - $200^{\circ} \mathrm{F}$ Well

WESTERN POLYMER CORPORATION

Geothermal Conversion

First-Year Expenses and Investment. Costs

Item

1. Drill one wel1

2. Well pumps

3. Pump test

4. Power line

5. Pipeline

includes 4-in. asbestos cement insulated and trench

$\$ 12 /$ f.t., 15,000 feet

6. Centrifugal booster pump

7. Heat exchanger, water to air hot water coil and fan

8. Labor to install heat exchanger

9. In-plant air handling units for space heating

10. Engineering $10 \%$ of tangible costs

11. Contingency $10 \%$ (tangible)

12. Contingency intangible $25 \%$

TOTAL
Intangible

costs

$\$ 92,000$

5,000

4,000

180,000

5,000

2,000

2,000

15,000

23,900

23,900

24,000

$\$ 120,000$

$\$ 286,800$ 
Option I. Ten-Year Cash Flow Using

a 150 Percent Declining Balance Depreciation and 9 Percent Cost Capital

\begin{tabular}{|c|c|c|c|c|c|}
\hline Year & Depreciation & $\begin{array}{c}\text { After Tax } \\
\text { Cash Inflow } \\
\text { Due to Tax Credit } \\
\text { and Depreciation } \\
\end{array}$ & $\begin{aligned} & \text { After Tax } \\
& \text { Reduction } \\
& \text { in Fuel Costs } \\
&\end{aligned}$ & $\begin{array}{c}\text { Total Cash } \\
\text { Inflow } \\
\text { After Tax } \\
\end{array}$ & $\begin{array}{l}\text { Present Worth } \\
\text { of Cash Inflow } \\
\text { at } 9 \% \text { Annually }\end{array}$ \\
\hline 1 & $\$ 43,020$ & $\$ 78,009.60$ & $\$ 16,879.56$ & $\$ 94,889.16$ & $\$ 87,054.28$ \\
\hline 2 & 36,567 & $17,552.16$ & $18,145.53$ & $35,697.69$ & $30,046.03$ \\
\hline 3 & 31,082 & $14,919.36$ & $19,506.44$ & $34,425.78$ & $26,583.02$ \\
\hline 4 & 26,419 & $12,681.12$ & $20,969.43$ & $33,650.86$ & $23,839.12$ \\
\hline 5 & 22,457 & $10,779.36$ & $22,542.13$ & $33,321.35$ & $21,656.59$ \\
\hline 6 & 19,088 & $9,162.24$ & $24,232.79$ & $33,395.13$ & $19,912.42$ \\
\hline 7 & 16,225 & $7,788.00$ & $26,050.25$ & $33,838.24$ & $18,510.68$ \\
\hline 8 & 13,791 & $\dot{6}, 619.68$ & $28,004.02$ & $34,623.81$ & $17,376.52$ \\
\hline 9 & 11,723 & $5,627.04$ & $30,104.32$ & $35,731.14$ & $16,451.61$ \\
\hline 10 & 9,964 & $4,782.72$ & $32,362.15$ & $37,144.94$ & $15,690.43$ \\
\hline & & & & & $\$ 277,120.70$ \\
\hline
\end{tabular}

NOTE: Total Capital investment is $\$ 349,200$ after write-off of intangible costs and the $20 \%$ tax credit.

Ten year payback is $\$ 277,120.70$ exclusive of pumping and maintenance costs for the geothermal system. Project is not economically feasible. 
TABLE $X$

Option I. Ten-Year Cash Flow Using

a 200 Percent Declining Balance Depreciation

and 9 Percent Cost Capital

\section{Alternative $A$}

\begin{tabular}{|c|c|c|c|c|c|}
\hline Year & Depreciation & $\begin{array}{l}\text { After Tax } \\
\text { Cash Inflow } \\
\text { Due to Tax Credit } \\
\text { and Depreciation }\end{array}$ & $\begin{array}{c}\text { After Tax } \\
\text { Reduction } \\
\text { in Fuel Costs } \\
\end{array}$ & $\begin{array}{l}\text { Total Cash } \\
\text { Inflow } \\
\text { After Taxes } \\
\end{array}$ & $\begin{array}{l}\text { Present Worth } \\
\text { of Cash Inflow } \\
\text { at } 9 \% \text { Annually }\end{array}$ \\
\hline 1 & $\$ 57,360$ & $\$ 84,893$ & $\$ 16,879.20$ & $\$ 101,772.00$ & $\$ 93,368.81$ \\
\hline 2 & 45,888 & 22,026 & $18,145.14$ & $40,171.38$ & $33,811.45$ \\
\hline 3 & 36,710 & 17,621 & $19,506.03$ & $37,727.02$ & $28,668.87$ \\
\hline 4 & 29,368 & 14,097 & $20,968.98$ & $35,065.77$ & $24,841.48$ \\
\hline 5 & 23,495 & 11,277 & $22,541.65$ & $33,819.09$ & $21,980.09$ \\
\hline 6 & 18,796 & 9,022 & $24,232.27$ & $33,254.22$ & $19,828.41$ \\
\hline 7 & 15,037 & 7,218 & $26,049.70$ & $33,267.25$ & $18,198.33$ \\
\hline 8 & 12,029 & 5,774 & $28,003.42$ & $33,777.47$ & $16,951.77$ \\
\hline 9 & 9,623 & 4,619 & $30,103.68$ & $34,722.92$ & $15,987.40$ \\
\hline 10 & 7,699 & 3,695 & $32,361.45$ & $36,056.84$ & $15,230.80$ \\
\hline & & & & & $\$ 288,86$ \\
\hline
\end{tabular}

NOTE: Option I does not pay back the original investment in the first ten years exclusive of pumping and maintenance costs for the geothermal system. 


\section{TABLE XI \\ Option II - $72^{\circ} \mathrm{F}$ Well (Existing) \\ WESTERN POLYMER CORPORATION \\ Geotherma 1 Conversion \\ First-Year Expenses and Investment costs}

\section{Item}

Tangible Costs

1. Pipeline - supply includes 4-in. asbestos cement insulated pipe and trench, $\$ 12 / \mathrm{ft}$., 300 feet, and $\$ 3 / \mathrm{ft}$., 200 feet noninsulated return

$\$ 4,500$

2. Heat exchanger, water to air hot water coil and fan

5,000

3. Labor to install heat exchanger

2,000

4. Valves

1,000

5. Engineering $10 \%$ of tangible costs

1,250

6. Contingency $10 \%$ of tangible costs

1,250 TOTAL

$\$ 15,000$ 
TABLE XII

Option II. Ten-Year Cash Flow Using

a 200 Percent Declining Balance Depreciation and 9 Percent Cost Capital

\begin{tabular}{|c|c|c|c|c|c|c|c|}
\hline Year & Depreciation & $\begin{array}{l}\text { Due } \\
\text { and }\end{array}$ & $\begin{array}{l}\text { Cash Inflow } \\
\text { to Tax Credit } \\
\text { Depreciation }\end{array}$ & $\begin{array}{c}\text { After Tax } \\
\text { Reduction } \\
\text { in Fuel Costs } \\
\end{array}$ & $\begin{array}{l}\text { Total Cash } \\
\text { Inflow } \\
\text { After Taxes }\end{array}$ & $\begin{array}{l}\text { Present Worth } \\
\text { of Cash Inflow } \\
\text { at } 9 \% \text { Annually }\end{array}$ & $\begin{array}{c}\text { Present } \\
\text { Worth }\end{array}$ \\
\hline 1 & $\$ 3,000$ & & $\$ 4,440$ & $\$ 6,407$ & $\$ 7,771.49$ & $\$ 7,129.81$ & $\$ 5,672.62$ \\
\hline 2 & 2,400 & & 1,152 & 6,887 & $4,733.36$ & $3,983.97$ & $2,521.90$ \\
\hline 3 & 1,920 & & 922 & 7,404 & $4,771.56$ & $3,684.52$ & $1,855.66$ \\
\hline 4 & 1,536 & & 737 & 7,959 & $4,875.99^{\circ}$ & $3,454.27 \leftarrow \star$ & $1,384.14$ \\
\hline 5 & 1,229 & & 590 & 8,556 & $5,038.93$ & $3,274.96$ & $1,044.08$ \\
\hline 6 & 983 & & 472 & 9,198 & $5,254.65$ & $3,133.18$ & 794.73 \\
\hline 7 & 786 & & 377 & 9,888 & $5,518.99$ & $3,019.08$ & 609.28 \\
\hline 8 & 629 & & 302 & 10,629 & $5,829.10$ & $2,925.43$ & 469.72 \\
\hline 9 & 503 & & 242 & 11,426 & $6,183.24$ & $2,846.93$ & 363.69 \\
\hline \multirow[t]{2}{*}{10} & 403 & & 193 & 12,283 & $6,580.54$ & $2,779.69$ & 282.52 \\
\hline & & & & & & $\$ 36,231.84$ & $\$ 14,993.35$ \\
\hline
\end{tabular}

*Payback period

ROI based on 200 percent declining balance depreciation and a 15 percent reduction in fuel costs which are inflating at 7-1/2 percent per year. 
TABLE XIII

\section{Option III - Drilling Existing Well Deeper \\ WESTERN POL YMER CORPORATION Geothermal Conversion \\ First-Year Expenses and Investment Costs}

\section{I tem}

1. Drill old well to 3,000 feet

2. We1l pumps

3. Pump tests

4. Heat exchangers

5. Labor to install heat exchangers

6. In-plant air handling units for space heating

7. Transmission 1 ine - 300 feet o 13.25/ft.

4-in. asbestos cement insulated and trenched

8. Engineering $10 \%$ of tangible cost

9. Contingency $10 \%$ of tangible cost

10. Contingency $25 \%$ of intangible cost TOTALS

Tax reduction

Net intangible cost

\section{Intangible \\ Costs}

$\$ 45,000$

$\$$

30,000

4,000

2,000

2,000

15,000

3,975

5,298

5,298

12,250

$\$ 61,250$

$\$ 63,570$

29,400

$\$ 31,850$ 
TABLE XIV

Option III. Ten-Year Cash Flow Using

a 200 Percent Declining Balance Depreciation

and 9 Percent Cost Capital

A

Year Depreciation

$\begin{array}{rr}1 & \$ 12,714 \\ 2 & 10,171 \\ 3 & 8,137 \\ 4 & 6,510 \\ 5 & 5,203 \\ 6 & 4,166 \\ 7 & 3,333 \\ 8 & 2,666 \\ 9 & 2,133 \\ 10 & 1,706\end{array}$

$\mathrm{F}$

Annua 1 Savings

Year Before Taxes

\section{$1 \$ 28,795.70$}

$230,998.23$

$3 \quad 33,368.39$

$4 \quad 35,918.91$

$5 \quad 38,663.44$

$6 \quad 41,616.70$

$7 \quad 44,794.49$

$848,213.83$

$9 \quad 51,893.01$

10
B Cash Inflow Due to Tax Credit and Depreciation

$$
\begin{array}{r}
\$ 18,817 \\
4,882 \\
3,906 \\
3,125 \\
2,500 \\
2,000 \\
1,600 \\
1,280 \\
1,024 \\
819
\end{array}
$$

G

Total Annual Saving
in Reduced Fuel Costs

$$
\begin{array}{r}
\$ 32,460.69 \\
34,895.25 \\
37,512.39 \\
40,325.82 \\
43,350.26 \\
46,601.52 \\
50,096.64 \\
53,853.89 \\
57,892.93 \\
62,234.90
\end{array}
$$

Annual Savings Annual Savings After Taxes After Taxes incl. Includes $15 \%$ Depreciation \& Depletion Allow. Investment $\mathrm{Cr}$.

$$
\begin{array}{r}
\$ 17,047.05 \\
18,350.95 \\
19,754.09 \\
21,263.99 \\
22,888.76 \\
24,637.09 \\
26,518.34 \\
28,542.59 \\
30,720.66 \\
33,069.28
\end{array}
$$

Present Worth of Cash Inflow ति $9 \%$

$\$ 32,902.80$

$19,554.71$

$18,269.93$

$17,277.78$

$16,500.95 * *$

$15,882.82$

$15,381.69$

$14,966.95$

$14,616.12$

$14,314.78$

$179,668.54$$$
\mathrm{H}
$$

C

D Annual Electrical Costs for Well Pump

$\$ 3,1$

$\$ 3$,

$3,180.00$
526.22

570.95

619.48

672.13

729.27

791.25

858.51

931.48

$1,002.09$

I

E Annual Maint. Costs for Geothermal Sys.

$$
\begin{array}{r}
3,180.00 \\
3,370.80 \\
3,573.05 \\
3,787.43 \\
4,014.68 \\
4,255.56 \\
4,510.89 \\
4,781.54 \\
5,068.44 \\
5,372.54
\end{array}
$$

J

Present Worth of Cash Inflow (a) $26.5 \%$

$\$ 28,351.03$

$14,518.55$

$11,688.12$

$9,524.27$

$7,837.70$

$6,500.45$

$5,424.45$

$4,548.01$

$3,826.98$

$33,888.28$
$3,229.57$

$95,449.14$
$\mathrm{Rv}=6,828$

ROI $26.5 \%$

*Payback period 
TABLE XIII

Option III - Drilling Existing Well Deeper

WESTERN POLYMER CORPORATION

Geothermal Conversion

First-Year Expenses and Investment Costs

Item

1. Drill old well to 3,000 feet

2. We11 pumps

3. Pump tests

4. Heat exchangers

5. Labor to install heat exchangers

6. In-plant air handling units for space heating

7. Transmission 1ine - 300 feet a 13.25/ft. 4-in. asbestos cement insulated and trenched

8. Engineering $10 \%$ of tangible cost

9. Contingency $10 \%$ of tangible cost

10. Contingency $25 \%$ of intangible cost TOTALS

Tax reduction

Net intangible cost
Intangible

Costs

$\$ 45,000$

$\$$

30,000

4,000

2,000

2,000

15,000

3,975

5,298

5,298

12,250

$\$ 61,250$

$\$ 63,570$

29,400

$\$ 31,850$ 
TABLE XIV

Option III. Ten-Year Cash Flow Using

a 200 Percent Declining Balance Depreciation

and 9 Percent Cost Capital

A

Year Depreciation

$1 \$ 12,714$

$2 \quad 10,171$

$3 \quad 8,137$

46,510

$5 \quad 5,203$

64,166

$7 \quad 3,333$

$8 \quad 2,666$

9

10

2,133

1,706

$\mathrm{F}$

Annual Savings

Year Before Taxes

$1 \$ 28,795.70$

$2 \quad 30,998.23$

$3 \quad 33,368.39$

$4 \quad 35,918.91$

$5 \quad 38,663.44$

$6 \quad 41,616.70$

$7 \quad 44,794.49$

$848,213.83$

$9 \quad 51,893.01$

$10 \quad 55,860.27$

G

Cash Inflow Due to Tax Credit

Annual Savings and Depreciation

\begin{tabular}{l} 
in Reduced \\
Fuel Costs \\
\hline
\end{tabular}

$\$ 18,817$

4,882

$\$ 32,460.69$

3,906

3,125

2,500

2,000

1,600

1,280

1,024

819

Total

Annual Savings Annual Savings

After Taxes After Taxes incl.

Includes $15 \%$

Depreciation \&

Depletion Al low. Investment $\mathrm{Cr}$.

$$
\$ 17,047.05
$$

$18,350.95$

$19,754.09$

$21,263.99$

$22,888.76$

$24,637.09$

$26,518.34$

$28,542.59$

$30,720.66$

$33,069.28$
$34,895.25$

$37,512.39$

$40,325.82$

$43,350.26$

$46,601.52$

$50,096.64$

$53,853.89$

$57,892.93$

$62,234.90$

H

D

Annual Electrical Annual Maint.

Costs for Well Pump

$\$ 3,180.00$

570.95

619.48

672.13

729.27

791.25

858.57

931.48

$1,002.09$

I

\begin{tabular}{c} 
Present Worth \\
of Cash Inflow \\
त $9 \%$ \\
\hline
\end{tabular}

Present Worth

of Cash Inflow d. $26.5 \%$

$\$ 32,902.80$

$\$ 28,351.03$

$19,554.71$

$18,269.93$

$17,277.78$

$14,518.55$

$23,660.09$

$24,383.99$

$25,388.76$

$26,637.09$

$28,118.34$

$29,822.59$

$31,744.66$

$33,888.28$
Costs for Geothermal Sys.

$\$ 3,180.00$

$3,370.80$

$3,573.05$

$3,787.43$

$4,014.68$

$4,255.56$

$4,510.89$

$4,781.54$

$5,068.44$

$5,372.54$
$16,500.95 * \star$

$9,524.27$

$15,882.82$

$7,837.70$

$6,500.45$

$15,381.69$

$5,424.45$

$14,966.95$

$4,548.01$

$14,616.12$

$3,826.98$

$14,314.78$

$179,668.54$

$95,449.14$

$\mathrm{Rv}=6,828$

ROI $26.5 \%$

*Payback period 


\section{Greenhouses}

\section{a. General}

The Klamath Basin's climate is favorable for the development of a greenhouse industry production. Other regions of the United States that have major greenhouse industries and comparable climates are Cleveland, Ohio and Denver, Colorado. The Klamath Basin is comparable to Cleveland in both solar radiation and heating degree days; however, lags behind Denver in solar radiation (Green, 1977).

Nearly every type of terrestrial commercial crop has been grown in greenhouses. Geothermal resources of temperatures above $140^{\circ} \mathrm{F}$ have been used successfully for this application. Lowertemperature geothermaliy heated water can be utilized for greenhouses than for most agribusiness industries. However, heating greenhouses geothermaliy does require large quantities of water, especially if lower temperatures of water are utilized. It is possible that some areas within the study may have insufficient cold water of good quality to be used for irrigation and cooling, or the location may be remote from a labor force or transportation facilities. Each subarea of the Klamath Basin was evaluated from these criteria for determining the potential for geothermally heated greenhouses. (See Appendix C--Potential for Greenhouse Development in the Klamath Basin by Subarea.)

A recent memorandum to Oregon's governor from the State Forestry Department (March 1977) stated that, "Currently, nursery production (to grow tree seedlings for reforestation) is considerably below the production capability by about 27 percent . . .." However, a letter from the same office to the Department of Economic Development (May 1977) states that, "The nursery capacity that is in place at this time exceeds the projected demand by a considerable amount." These projections considered the next decade of Oregon's reforestation demands by the U.S. Forest Service and Bureau of Land Management, state and other public agencies, forest industry, and other private acreages. The estimated needs and potential supplies appear satisfactory at the present rate of production. About 25 percent of the total demands will be for container (greenhouse-grown) seedlings.

However, the demand and supply of seedlings depends upon the ability of greenhouses to economically and competitively grow the seedlings. Most greenhouses use natural gas as their heat energy source. A recently published survey by the National Association of Regulatory Utility Commissioners (July, 1977) stated that, "Residential (natural) gas prices are increasing at annual rates ranging from 20 percent to as high as 40 percent." 
Commercial gas rates have increased correspondingly. Furthermore, most greenhouse industries have been placed on interruptable supplies which could damage or destroy a large portion of Oregon's 41 million containerized seedling crops for any year. These combinations of events where the forest industry is dependent upon greenhouse-grown seedlings and the spiraling costs of undependable fossil fuel supplies, are the major reasons for the accelerated interests in geothermal heated greenhouses to grow the product.

b. Geothermal Heating System

The greenhouse business benefits from the size or scale of operation. For purposes of this study a one-acre unit house is used as the basis for a 15-acre operation.

Greenhouse heating and construction costs are based on a fiberglass furrow-connected gable structure covering 43,200 $\mathrm{ft}^{2}$ of floor area. Well depths and geothermal water temperature will vary depending on the selected site as indicated in the resource assessment section of this report. For purposes of economic analysis, $200^{\circ} \mathrm{F}$ geothermal waters at a depth of 1,500 feet were assumed. The chemical properties of waters in areas noted should not create excessive scaling or corrosion problems in heating equipment (fan coils and pipes) or pumps. Similar waters have been used directly for many years in Klamath Falls.

Greenhouse Design - One Acre Unit

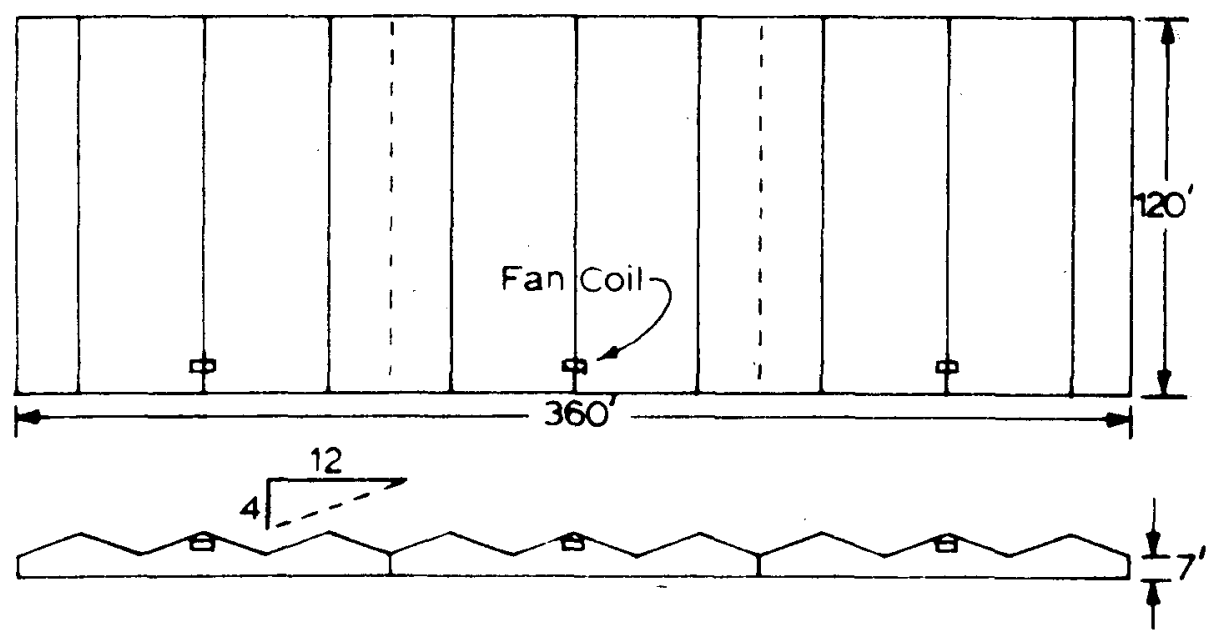


1. Size $-120^{\prime} \times 360^{\prime}=43,200 \mathrm{ft}^{2}$.

2. Outside design temperature $=-10^{\circ} \mathrm{F}$.

3. Design temperature inside greenhouse $=70^{\circ} \mathrm{F}$.

4. Building orientation--furrow-connected structure with ridges running north-south.

5. Cooling--single ceiling vent along each ridge and wall vents.

6. Heating--combination fan coils and horizontal pipes located on walls and under benches.

7. Heat loss from corrugated fiberglass furrow-connected gabled house-increase exposed surface by 18.8 percent (Green, 1977).
Flat surface
Corrugated surface
Exposed roof area - 45,530 $\mathrm{ft}^{2}$
$54,089 \mathrm{ft}^{2}$
Exposed
$q=U A \Delta T$
$9,600 \mathrm{ft}^{2}$
$11,405 \mathrm{ft}^{2}$
TOTAL
$55,130 \mathrm{ft}^{2}$
$65,494 \mathrm{ft}^{2}$

$$
\text { Roof: } \quad \begin{aligned}
q & =1.22 \frac{\mathrm{Btu}}{\mathrm{hr}-\mathrm{ft}^{2}-{ }^{\circ} \mathrm{F}} \times 54,089 \mathrm{ft}^{2} \times 65^{\circ} \mathrm{F} \\
& =4.29 \times 10^{6} \mathrm{Btu} / \mathrm{hr}
\end{aligned}
$$$$
\text { Walls: } \quad q=1.13 \frac{\mathrm{Btu}}{\mathrm{hr}-\mathrm{ft}^{2}-{ }^{\circ} \mathrm{F}} \times 11,405 \mathrm{ft}^{2} \times 65^{\circ} \mathrm{F}
$$$$
=.84 \times 10^{6} \mathrm{Btu} / \mathrm{hr}
$$
Total heat loss $=5.13 \times 10^{6} \mathrm{Btu} / \mathrm{hr}$.
8. Annual heat loss $=\frac{6300 \mathrm{deg} \text { day }}{\mathrm{yr}} \times \frac{1}{65 \mathrm{deg}} \times \frac{24 \mathrm{hr}}{\text { day }} \times 5.13 \times 10^{6} \frac{\mathrm{Btu}}{\mathrm{hr}}$
9. Annual heat loss $(15$ acres $)=1,790,000$ therms $/ y r$. 


\section{Heating System Design}

Free convection from horizontal pipes is the method widely used for heating greenhouses with geothermal waters in Iceland and Europe (see Figure 39) and is the basis for the heating pipe network design used in this study.

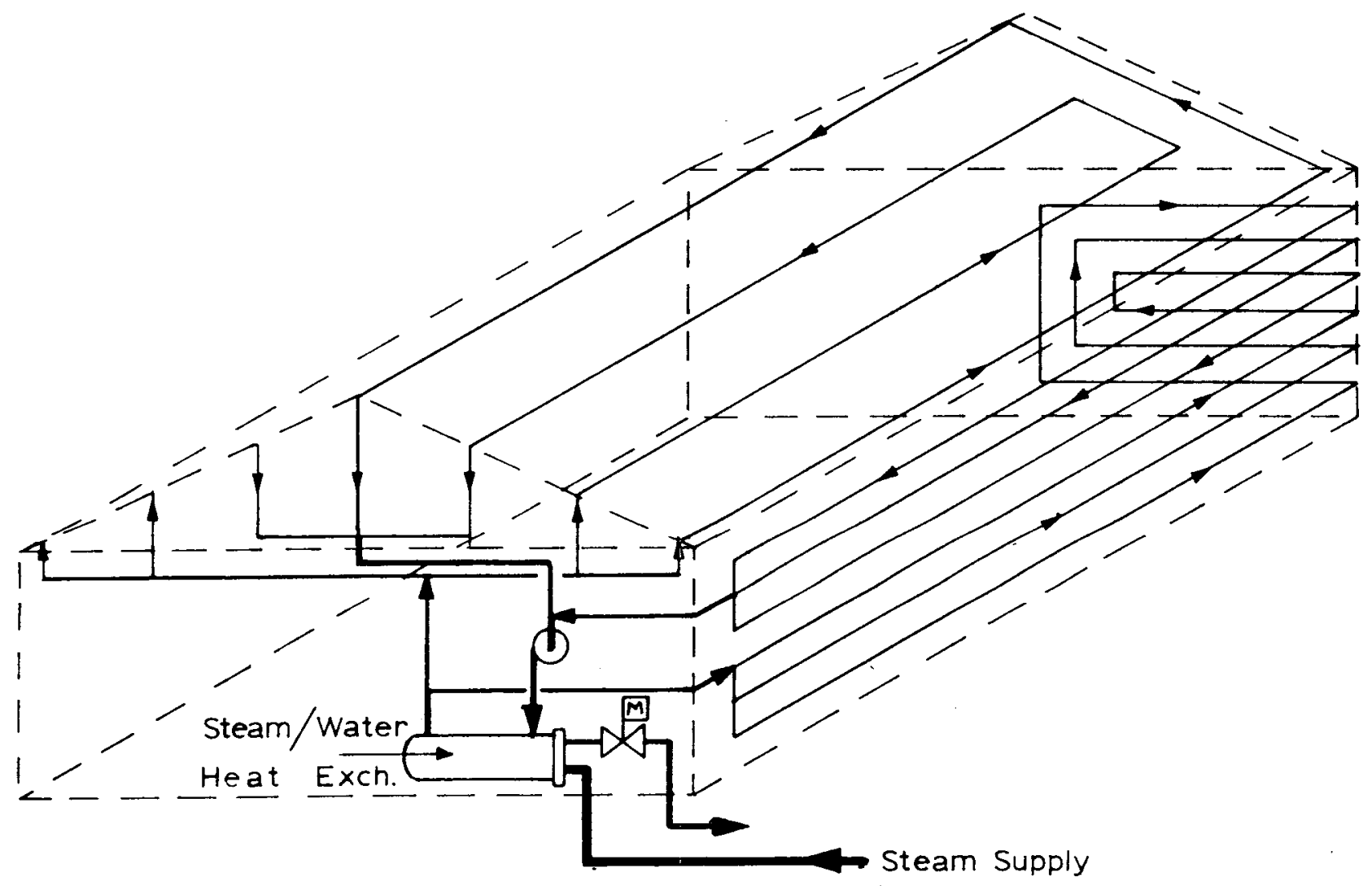

Figure 39. Heating pipe network for greenhouse at Hveragerdi, Iceland.

The system considered for this study consists of a fan coil connected in series with a network of horizontal pipes installed on outside walls and under benches, as shown in Figure 40 . Three of these systems are required for each one-acre house.

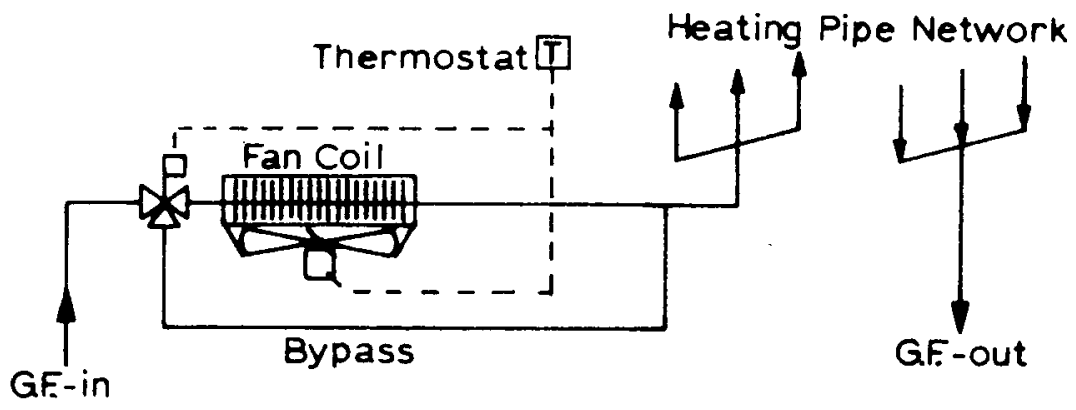

Figure 40. Unit Heating System Design (three per house) 
Heat transfer per unit length for horizontal pipe due to free convection and radiation is given by the following equation (McAdams, 1954):

$$
q=(h c+h r) A \Delta T
$$

Nested horizontal pipes mounted on outside walls prevent downdrafts caused by the cold walls and radiation transmitted through fiberglass is negligible due to the long wavelength produced by the low-temperature pipes.

Bare Pipe Convection

Heat transfer from the network of two-inch horizontal pipes for a one-acre greenhouse:

$$
q=165 \mathrm{Btu} / \mathrm{hr}-\mathrm{ft} \times 19,000 \mathrm{ft}=3,135,000 \mathrm{Btu} / \mathrm{hr}
$$

The pipe network, operating independently of the fan coils, supplied with $200^{\circ} \mathrm{F}$ geothermal waters would heat the house down to an ambient temperature of $15^{\circ} \mathrm{F}$ or provide for all but 10 percent of the annual heating requirements. Three fan coils, each rated at $655,000 \mathrm{Btu} / \mathrm{hr}$, would be required to heat the greenhouse on the coldest winter day, with reject water from each fan coil going through the network of heating pipes. A thermostat located inside the house would control the water flow through the house by means of a motorized valve and the motor of the fan coil.

\section{Finned-Tube Convectors}

Heat transfer from a two-row network of two-inch finned-tube convectors (4-1/2-inch fins, 33/ft) with a supply temperature of $180^{\circ} \mathrm{F}$ is rated at $1570 \mathrm{Btu} / \mathrm{hr}-\mathrm{ft}$. The heat transfer from convectors mounted on outside walls is:

$$
q=1570 \mathrm{Btu} / \mathrm{hr}-\mathrm{ft} \times 1,440 \mathrm{ft}=2,261,000 \mathrm{Btu} / \mathrm{hr}
$$

Additionally, three fan coils rated at 956,000 Btu/hr each would be required to heat the greenhouse on the coldest winter day.

\section{Distribution System}

For a 15-acre complex, a double-pipe system is used to circulate water to a 60,000-galion storage tank. The supply water to the greenhouses is maintained at $180^{\circ} \mathrm{F}$ by mixing entering $200^{\circ} \mathrm{F}$ water from the wells and the return water from the houses. When the return water temperature drops below $90^{\circ} \mathrm{F}$, the valve to the return well opens and closes at a preset higher temperature, and water is disposed of by means of the injection well. This 
double-pipe system illustrated in Figure 41 reduces the number of production wells required by extracting $110 \mathrm{Btu}$ per pound of water. Geothermal water demand on the coldest winter day is $93 \mathrm{gpm}$ for a one-acre house.

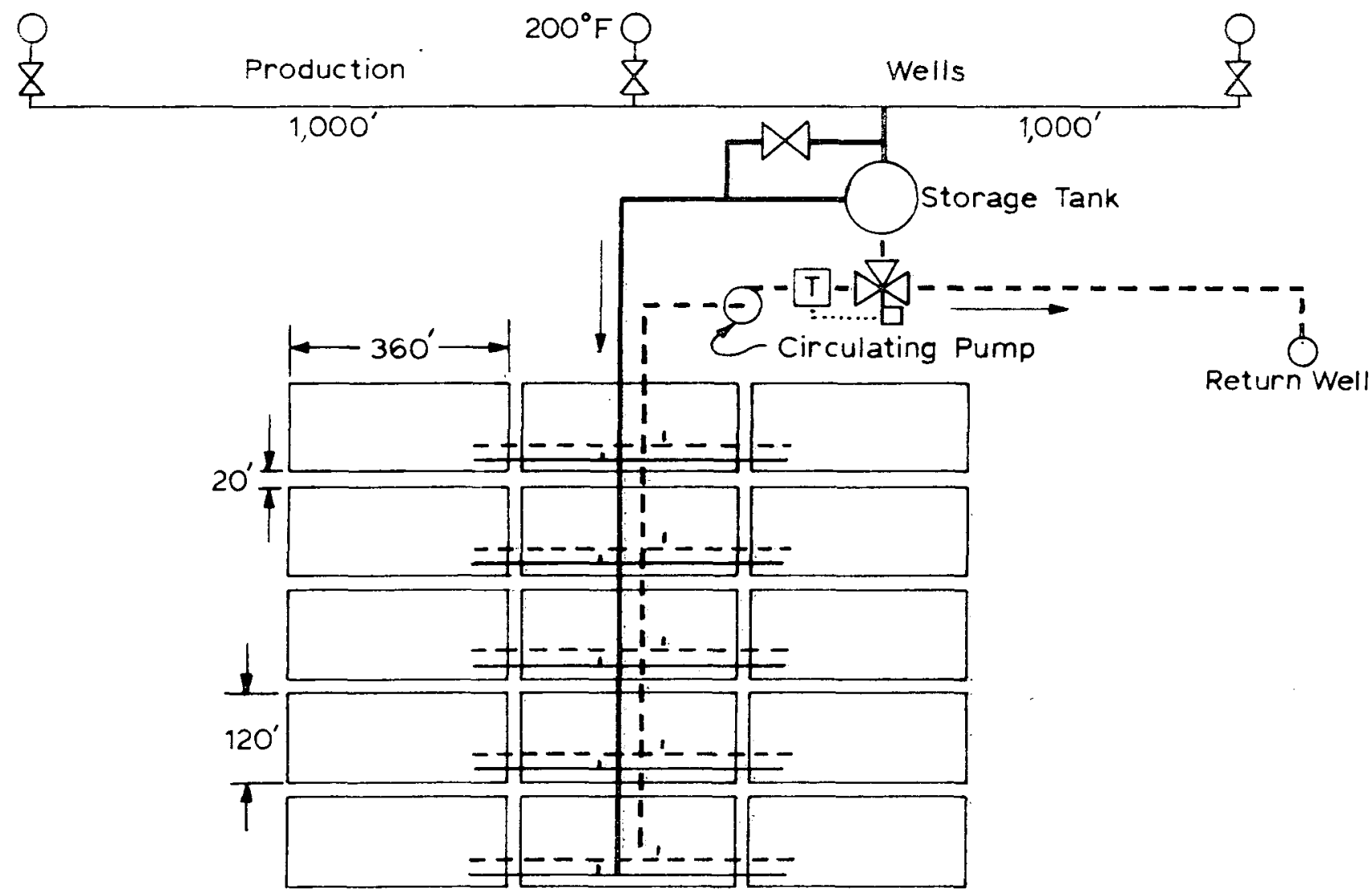

Figure 41. Fifteen-acre greenhouse complex.

The 15-acre complex would require 1,395 gpm with the water flowing directly through the system to the injection well.

For purposes of this study it is assumed each well is drilled to an average depth of 1,500 feet and is capable of producing 500 to $600 \mathrm{gpm}$ of $200^{\circ} \mathrm{F}$ geothermal waters. Three production wells and one return well would be required for a 15-acre greenhouse complex. Deep-well shaft-driven turbine pumps (50 hp), controlled by the water level in the storage tank, are installed at each well.

Insulated asbestos cement pipe buried to a depth of three feet is used for the transmission line. Bare asbestos cement supply and return pipe buried under the houses are used for the distribution system. 


\section{c. Economic Analysis}

The economic analysis for greenhouses was accomplished using a 15-acre greenhouse complex. This was considered to be an optimal size since it requires three production wells and a return well. It was estimated that the production wells would operate on an average of 12 hours per day throughout the year. It was felt that during the three coldest months of the year nearly 100 percent of operation from all wells would be required during the night or periods of heavy overcast and during the three warmest months of the year production would be practically zero. The remaining six months would require maintaining of temperatures overnight which could be done with minimal production and the use of the recirculating storage tank. While the annual cost per one-acre greenhouse heated by natural gas would be a linear function and could simply be multiplied by the number of oneacre greenhouses, it would not be economically feasible to drill a production and return we11 for one acre of geothermal greenhouses. Since one production well could serve five acres of greenhouses and three production wells could serve 15 acres of greenhouses with the requirement of only a single return well, the annual costs of geothermal greenhouses are reduced drastically by economies of scale. 
TABLE XV

INVESTMENT COSTS FOR A 15-ACRE GREENHOUSE COMPLEX

1. Land

2. 15 houses $-43,200 \mathrm{ft}^{2}$ o $\$ 2.75 / \mathrm{ft}^{2}$

3. Outfitting house $-\$ 1 / \mathrm{ft}^{2}$

4. Heating and cooling equipment

5. Engineering o $10 \%$

6. Contingency o $10 \%$

Total investment

Depreciable investment
Natural Gas

$\$ 15,000$

$1,782,000$

648,000

$635,000 \star$

308,000

308,000

$\$ 3,696,000$

$\$ 3,681,000$

Geothermal

$\$ 15,000$

$1,782,000$

648,000

687,000

313,200

313,200

$\$ 3,758,400$

$\$ 3,743,400$

\section{TABLE XVI}

GREENHOUSE CONVERSION COSTS FOR GEOTHERMAL ENERGY

\section{Energy Costs}

1. 3 wells $-1,500$ feet deep

a. $\$ 38,000 /$ well

1 return well

2. 3 deep-well turbine pumps - $50 \mathrm{hp}$

3. Pump tests

4. Power line

5. Pipeline (includes installation)

6. Circulating pump - $35 \mathrm{hp}$

7. Storage tank - 60,000-gallon

8. Engineering a $10 \%$ (tangible costs)

9. Contingency a $10 \%$ (tangible costs)

10. Contingency a $25 \%$ (intangible costs)

These costs will be expensed in the first year

These costs yield a $20 \%$ investment tax credit

\section{Intangible}

Tangible

$\$ 114,000 \quad \$$

38,000

$$
4,000
$$

60,000

15,000

74,000

5,000

15,000

16,900

39,000

16,900

$\$ 195,000$

$\$ 202,800$ 
TPABLE XVII

GREENHOUSE ANNUAL OPERATING AND MAINTENANCE COSTS

The following costs are estimated to increase by 6 percent per year.

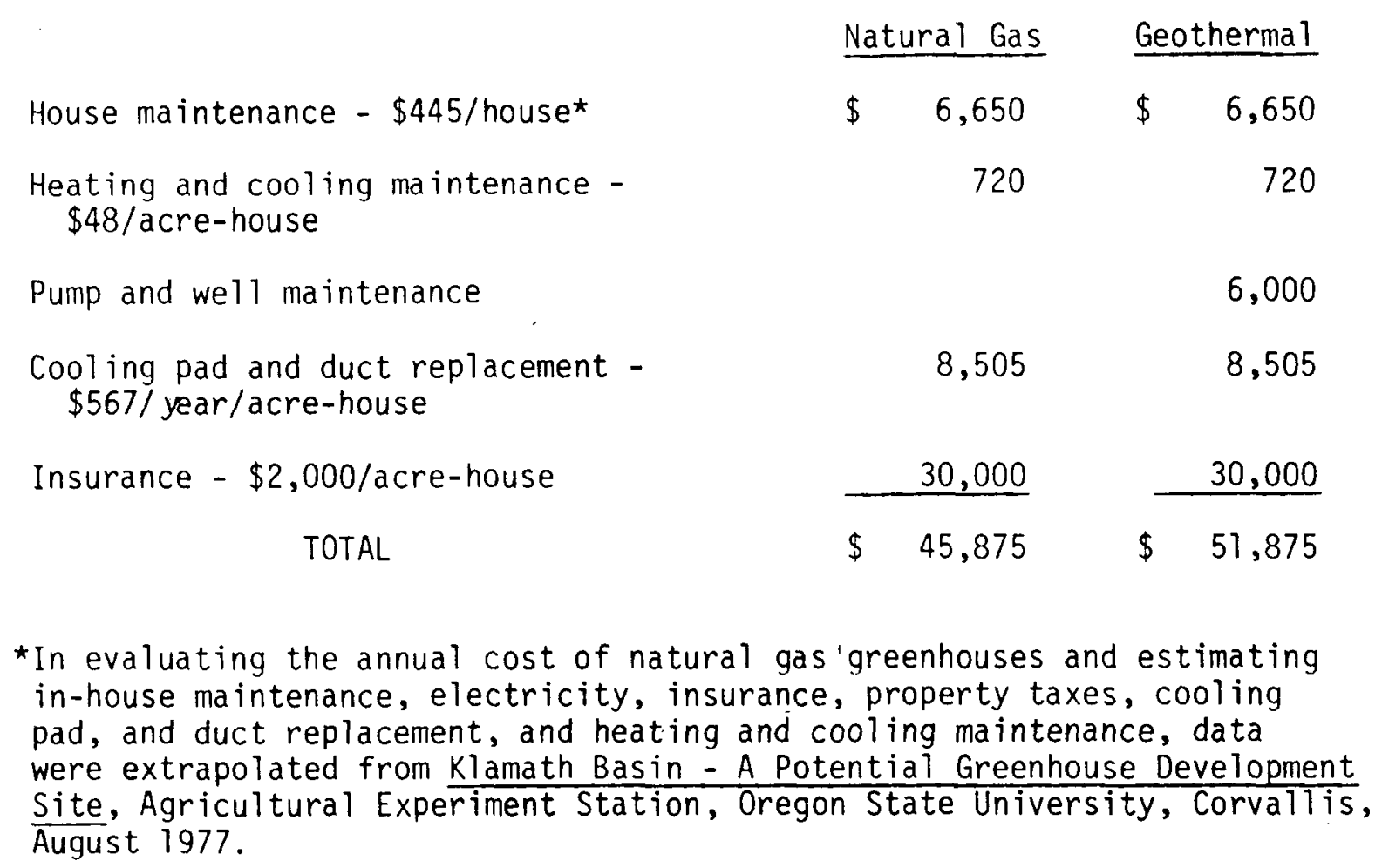


TABLE XVIII

TWENTY-YEAR PROJECTION OF ANNUAL ENERGY COSTS

FOR A 15-ACRE GREENHOUSE COMPLEX

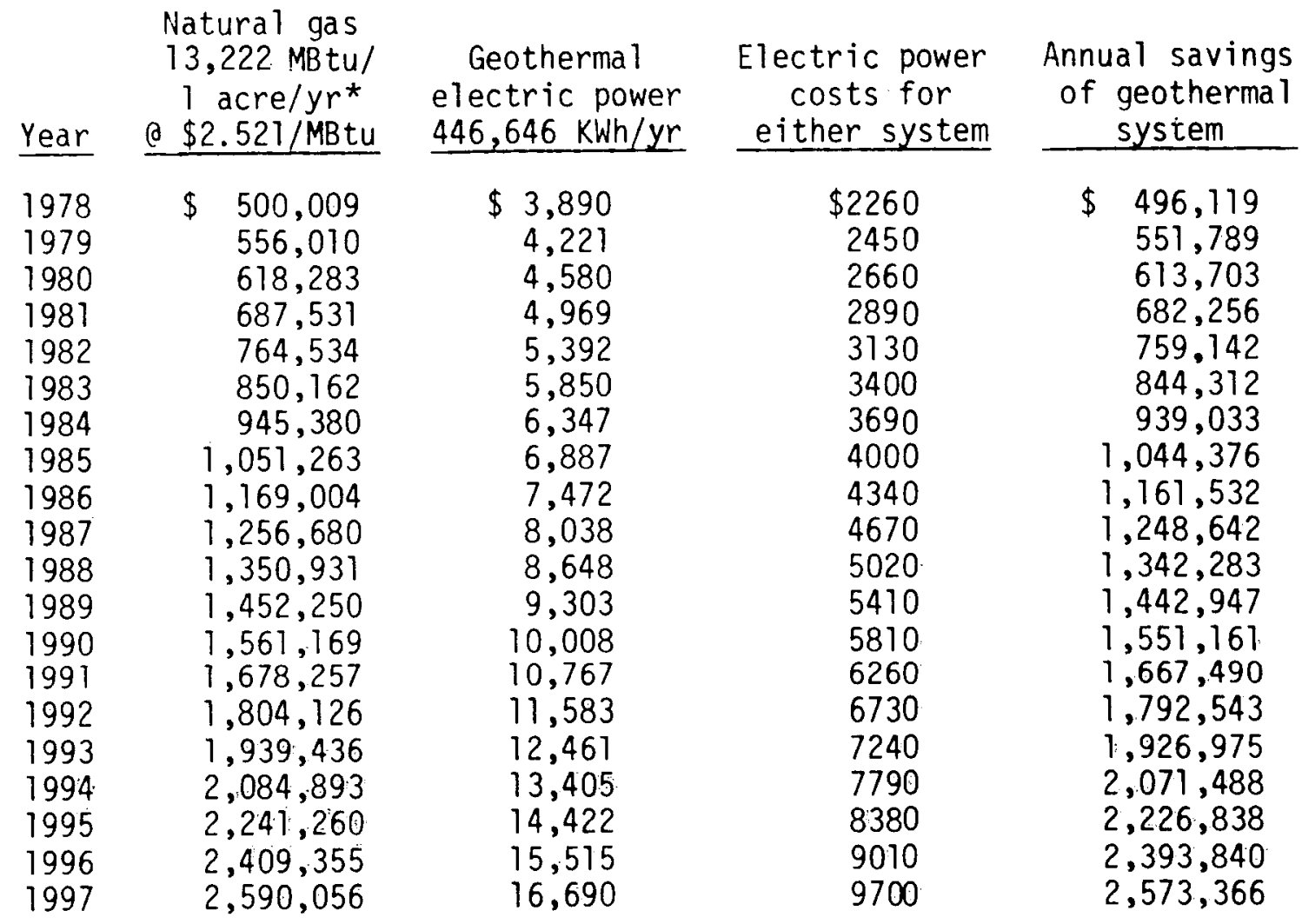

* Heating efficiency for natural gas is 90 percent. 
The total annual equivalent costs of a 15-acre greenhouse complex (see Table XXI) were calculated using a 9 percent per annum cost of capital assuming a 20-year life, as follows:

1) First-year investment tax credit was discounted at 9 percent and subtracted from the total capital investment for the 15-acre greenhouse complex.

2) A 20 percent tax investment credit was discounted at 9 percent and subtracted from the tangible investment in the geothermal system.

3) The tangible costs associated with the geothermal system were considered to be expenses in the first year, reducing federal income taxes by 48 percent, and the resulting reduced taxes were discounted at 9 percent and subtracted from the total tangible investment.

4) The annual cost of insurance in house maintenance, heating and cooling system maintenance, well and pump maintenance, was inflated at a rate of 6 percent per annum, which is assumed to be the economic inflation rate.

5) Property taxes were inflated at a rate of .1 percent per annum. Annual electrical energy costs were inflated at a rate of 8-1/2 percent per annum through 1986, and at 7.58 percent per annum thereafter. These inflation rates for electricity were obtained from the Oregon Department of Energy.

The annual equivalent costs for a 15-acre complex heated with natural gas were calculated in the same manner except that there were no intangible costs, and inflation rates for industrial natural gas were assumed to be 11.2 percent per annum through 1986 and $7-1 / 2$ percent per annum thereafter. 
TABLE XIX

EQUIVALENT ANNUAL COST FOR A 15-ACRE GREENHOUSE COMPLEX.

ASSUME A 20-YEAR LIFE AND A 9 PERCENT PER ANNUM COST OF CAPITAL.

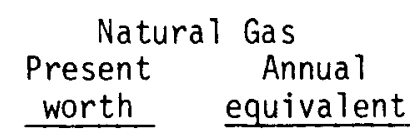

Capital investment in 15-acre complex and equipment less $10 \%$ investment tax credit discounted at $9 \%$

Tangible energy investment less $20 \%$ investment tax credit discounted at $9 \%$

Intangible energy investment expensed in first year less reduced federal taxes discounted at 9\% (assumes $48 \%$ federal taxes)

TOTAL FIRST-YEAR COSTS $\begin{array}{r}\$ 3,696,000 \\ -\quad 339,083 \\ \hline \$ 3,356,917\end{array}$

$-0-\quad-0-$

$-0-$

$-0-$

$\$ 3,356,917$
Annual maintenance and insurance

(inflation $6 \%$ per annum)

Property taxes (inflation . $1 \%$ per annum)

Electrical power costs (inflation 8.5\% through 1986 and $7.58 \%$ thereafter)

Natural gas annual costs (inflation

$11.2 \%$ through 1986 and. $7.5 \%$ thereafter)

TOTAL ANNUAL EQUIVALENT COST
$\$ 81,026$

51,835

4,240

$\$ 3,688,310$

51,835

7,713
Geotherma]

Present Annual

worth equivalent

$\$ 3,758,400$

$-\quad 344,807$

$\$ 373,947$

$\$ 202,800$

$-\quad 37,211$
$\$ 165,589$

$\$ 18,140$

$\$ 195,000$

$\frac{85,872}{\$ 109,128}$

$\$ \quad 11,955$

$\$ 71,654$

$1,087,967$

$-0-$

$\$ 1,579,618$

$\$ 544,616$ 


\section{TABLE XX \\ ADDITIONAL CAPITAL INVESTMENT REQUIRED \\ FOR A GEOTHERMAL COMPLEX}

$\$ 331,393$

\begin{tabular}{cccc} 
Year & Annual savings & $\begin{array}{r}\text { Discounted cash flow before taxes } \\
150 \%\end{array}$ & \begin{tabular}{r}
$160 \%$ \\
\cline { 3 - 4 } 1
\end{tabular} \\
\cline { 2 - 4 } 2 & $\$ 496,119$ (note) & $\$ 198,448$ & $\$ 190,816$ \\
3 & 551,789 & 88,286 & 81,626 \\
4 & 613,703 & 39,278 & 34,917 \\
5 & 682,256 & $17,466 \star$ & 14,930 \\
6 & 759,142 & & 5,389 \\
7 & 844,312 & & $2,733^{\star}$ \\
8 & 939,033 & & \\
10 & $1,044,376$ & & \\
11 & $1,161,532$ & & \\
12 & $1,248,642$ & & \\
\multicolumn{1}{c}{$1,342,283$} & & \\
& $1,442,947$ & & $\$ 331,410$
\end{tabular}

*Payback period

NOTE: Investment pays back in one year at 49.7 percent 
In calculating an ROI, it is only necessary to consider the cost differences between the conventional and geothermal heating system. Additional capital investment of $\$ 331,393$ is required for the geothermal system. Examining the energy costs in Table $X X$, it becomes obvious that the ROI is in excess of 100 percent. When using the equivalent annual cost formula with projected energy costs, those costs that are projected into the future ten years or more become insignificant with an ROI in excess of 100 percent. For example, the costs of natural gas from 1987 through 1997 begin with a relative high annual amount of $\$ 1,256,680$ annually and inflate at a rate of 7.5 percent a year. However, when calculated at a rate of return of 160 percent, these costs have a present value of only $\$ 89$. Annual costs of $\$ 10,000$ or less approach zero in present value and become insignificant. The ROI was calculated at 160 percent and gave a payback in six years, indicating the ROI is higher than 160 percent. A ROI calculation was done for 165 percent and yielded no payback, indicating the ROI was slightly higher than 160 percent; therefore, the ROI is assumed to be approximately 162 percent.

\section{Western Snake River Basin Assessment}

\section{Background}

Some understanding of the physical geography of the basin is necessary in order to realize the agricultural and agribusiness potential of the area. The benchlands of the Oregon portion of the Snake River Basin were formed during a period of intensive volcanic activity in southwestern Idaho and eastern Oregon. Lava flows filled the stream valleys, including the Snake River, damming them and impounding Targe lakes. Several thousand feet of sediments were deposited in the lakes, which subsequently were drained by streams eroding through the basalt dams. Wind transported sediments and alluvial materials mantle extensive portions of the area and have matured into excellent agricultural sails which produce high yield crops where irrigation water is available.

The climate can be considered as semiarid, experiencing hot dry summers, cold winters and moderate spring and fall temperatures. The average temperatures for the Vale, Ontario, Nyssa area is about $10^{\circ} \mathrm{C}\left(50^{\circ} \mathrm{F}\right)$, with an average annual precipitation of 8 to 10 inches. The frost-free growing period in the agriculturally extensive area is 150 to 180 days per year.

Agriculture is the major base of the area's economy and food processing is the only major manufacturing activity. The major food processing crops produced are potatoes and sugar beets with minor crops of sweet corn and onions. In 1975, 10,200 acres of potatoes, 5,400 acres of sweet corn and 5,500 acres of onions were grown in Malheur County. Most of the onions are sold to the fresh vegetable market. 
The processing plants have historically depended primarily on natural gas for their energy supplies but are now in the process of changing to oil. One plant has already converted to using coal. The agribusiness industry consumes considerable quantities of relatively low-temperature heat in the range of $140^{\circ}$ to $300^{\circ} \mathrm{F}$ (Reistad, 1975). A major savings in fossil fuels could be achieved if food processing industries in the region could utilize geothermally heated waters for a portion of these energy requirements.

The geothermally heated greenhouse industry in the basin has been limited to three greenhouses at Vale which have been in production for more than 20 years. Their major crop has been foliage, flowering, and bedding plants. While no future exparision of this operation is anticipated, a five-acre greenhouse-mushroom growing complex is beginning construction adjacent to the present greenhouses.

Geothermal energy from the basin's reservoir could be used to reduce the wide fluctuations in agricultural incomes experienced in most farming areas. Greenhouses could be individualiy and/or cooperatively owned and managed by farm operators. Such activities would extend the season and produce crops not presently competitive in the area. A dehydrator could utilize other crops that are not presently grown on basin farms. Specifications for the Klamath Basin greenhouses and dehydrator presented earlier in this report could be utilized by using the cost charts in the introduction of this section to include the additional expenditures of deeper wells than in the Klamath Basin.

Comprehensive Land Use Plans for Malheur County, Oregon address the agricultural economy of the area. County planners anticipate changes which can be made in their long-range plans when geothermal energy resources can expand and stabilize the economic base for their area's residents.

2. The Amaigamated Sugar Company, Nyssa, Oregon

\section{a. General Description}

The Nyssa District of the Amalgamated Suaar Company is situated on the Oreoon-Idaho border near the Snake River in one of the nation's outstanding agriculture areas.

The Nyssa sugar factory--Oregon's only sugar processing plant-was built in 1938 and is the seventh largest beet sugar processing plant in the United States. This factory can process 6,300 tons of sugar beets every 24 hours. Approximately 200 tons per day of molasses is also worked by means of the Steffen process. The campaign usually starts 0ctober 10 and runs 120 to 125 days. During the campaign the company employs 450 people on a three shift per day basis. Off season, 160 full-time employees repair plant equipment and ship stored sugar and by-products. 
When the plant is operating, 615 tons of coal are burned in the boilers per day. A total of $2.02 \times 10^{12}$ Btu of coal and $1.15 \times$ $10^{11}$ Btu of natural gas were used during the 1976 season. The plant converted from burning natural gas as its main fuel supply to coal in the early 1970s. The plant has electric generators that produce $5000 \mathrm{kw}$; in addition $3000 \mathrm{kw}$ are purchased.

Steam is supplied from five boilers at $68.4 \mathrm{lb} / \mathrm{sec}$ (245 psia to 3000 and $541-\mathrm{kw}$ generators and 420 psia to the $1500-\mathrm{kw}$ generator) to the generators. Exhaust steam at about 50 psia pressure is used primarily for process in the first-effect evaporator. The company is trying to reduce energy consumption by 20 percent.

White Satin sugar processed at Nyssa is packaged in 25-, 50-, and 100-pound bags. Nyssa's sugar warehouse, the company's largest, can hold over 33,500 tons of bagged sugar for distribution to customers. Huge silos can hold an additional 43,500 tons of bulk sugar shipped to industrial customers and consumer markets.

The company's White Satin sugar is sold primarily to bakeries, canneries, bottlers, and other food processors in Utah, Idaho, Oregon, and Washington, as well as in eight midwest states.

The company's dried molasses beet pulp sales are coordinated through offices at Nyssa. This high protein livestock feed is sold to farmers and livestock feeders throughout six western states and three foreign countries.

\section{b. Processing Stages}

Preparation of sugar beets for processing is the step between harvesting and slicing operations. These steps include: receiving at the factory site; dirt and trash removal; short-term storage; beet flow control; final trash removal and final cleaning; and elevating to the factory slicers. The above steps to not use thermal energy.

In the following stages thermal energy is involved in the process. The processes may be conveniently separated into six stages:

1) diffusion; 2) juice purification; 3) evaporation; 4) crystallization, 5) dried pulp manufacture; and 6) recovery of sugar from molasses. The first three stages comprise the beet end of the factory, and the fourth stage the sugar end.

The composite flow sheet (Figure 42) and the following descriptions for the Steffen process, used at the Nyssa plant, will help in understanding the beet sugar manufacturing process and its energy requirements. 


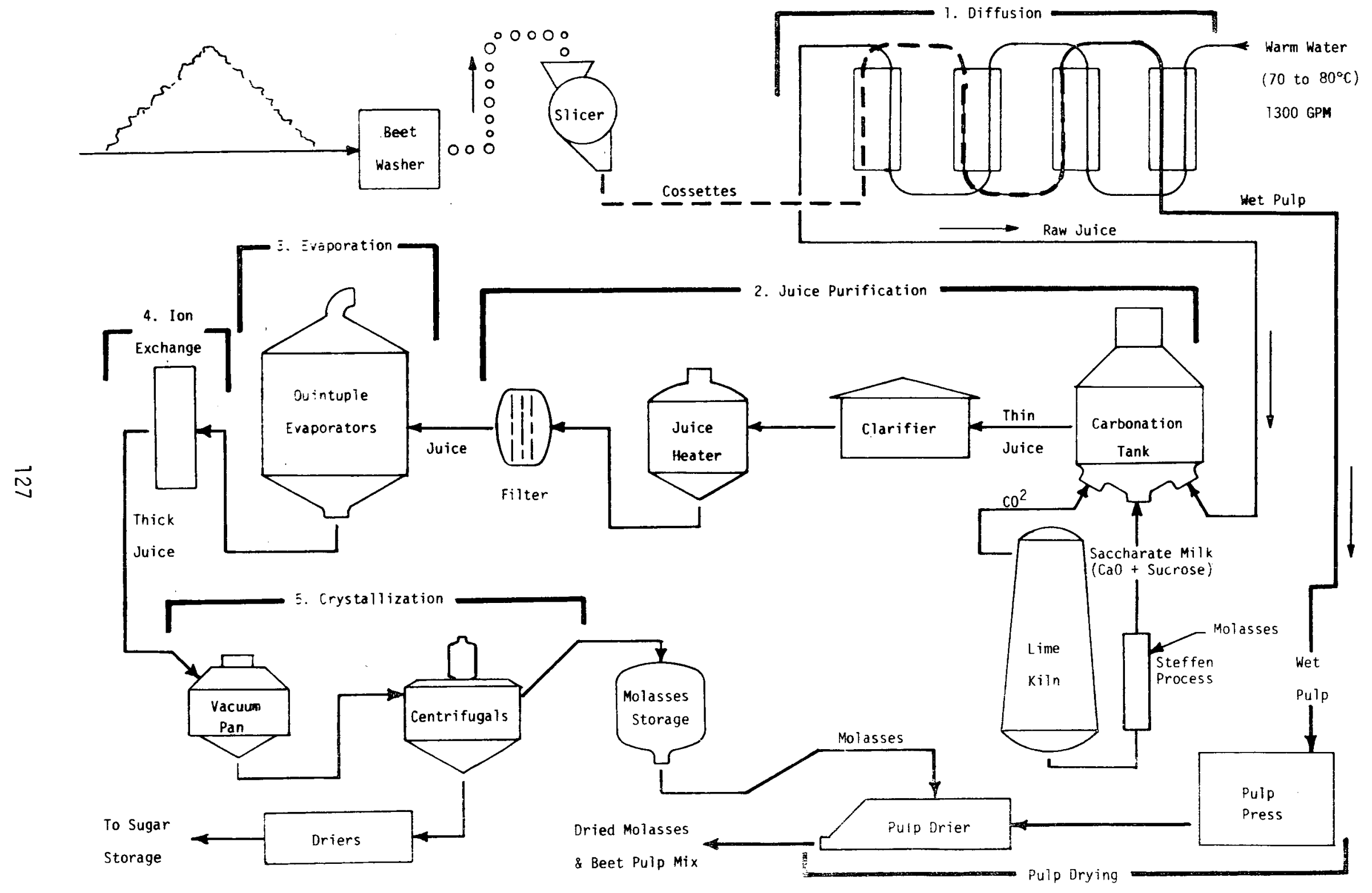

Figure 42. Processing stages--composite flow sheet. 


\section{1) Diffusion}

The diffusers separate from the long thin strips (cossettes) of sliced beets the pulp and raw juice. Continuous diffusers are used at the Nyssa plant. To start the process $78,300 \mathrm{gpm}$ of makeup water enters and percolates by gravity through the cossette mass, leaching out sugar as it proceeds countercurrent to the cossettes. The temperature is raised to between $158^{\circ}$ and $176^{\circ} \mathrm{F}$, for better extraction, by steam-heated jackets surrounding the trough. The rate of diffusion increases directly with temperature. The sugar loss in exhausted pulp is proportional to the product of time, temperature, draft, and cossette size. Higher temperatures in the diffuser make it possible either to lower the draft, to increase the size of cossettes, or to shorten the contact time between juice and cossettes without increasing sugar loss. The draft is the ratio of the weight of diffusion juice drawn from the diffuser to the weight of cossettes introduced expressed as percent. Drafts vary between 100 and 150 percent.

The steam required for the diffusers comes from the evaporator juice second vapor.

The sugar-depleted cossettes leaving the diffuser are known as pulp and are transferred to the pulp press and dryer. Sugarenriched juice is next introduced to the juice purification process. The diffusion juice contains between 10 and 15 percent sugar, which is about 98 percent of the sugar which was in the beets when sliced.

\section{2) Juice Purification}

It is necessary to purify the juice since it contains nonsugar impurities. The nonsugar impurities in both true and colloidal solution make it very difficult to concentrate the diffusion juice, or to crystallize pure sugar from it. Impurities are removed by introducing lime in the form of a slurry of calcium saccharates obtained from the Steffen process for extracting sugar from molasses. The $\mathrm{CO}_{2}$ bubbles are passed through the mixture to precipitate lime as very small calcium carbonate crystals. As the crystals precipitate the impurities coagulate and adher to the calcium carbonate crystals and can be settled out as a thickener in the clarifier. The purpose of a second carbonation is the removal of lime remaining in solution.

Second carbonation is at a lower pH; the precipitated calcium carbonate is removed by filtration. At this point the juice is known as thin juice. Preporatory and during purification, juice is heated from $148^{\circ}$ to $194^{\circ} \mathrm{F}$ plus the thermal energy used at lime kilns to produce $\mathrm{CaO}$ and $\mathrm{CO} 2$.

Thin juice is heated to $239^{\circ} \mathrm{F}$ and transported to the evaporators. 


\section{3) Evaporation}

Heat is required to evaporate water from the beet juices. This heat is supplied to the first-effect evaporator as steam from the electric generator turbine exhausts at 50 psia absolute. Thermal energy for this process consumes about 80 percent of the total energy produced at the plant.

Water evaporated from the beet juices in the first-effect evaporator leaves as vapor which is subsequently used in succeeding evaporator stages and other processes in the plant.

Multiple-effect evaporators are used with five individual bodies or effects, as shown on Figures 43 and $43 \mathrm{~A}$; turbine exhaust plus reduced pressure super-heated 1 ive steam makeup (77.2 $\mathrm{lb} / \mathrm{sec}$ tota 1 ) steam at $50 \mathrm{psia}$ is piped to the firsteffect steam chest. On condensing, this steam gives most of its heat to the juice in the first effect, $1 A$ and $1 B$; the transfer of heat causes the juice to boil. Vapor from the boiling first-effect juice passes through the evaporator dome and is piped into the vapor chest of the second-effect evaporators $(2 \mathrm{~A}, 2 \mathrm{~B}$, and $2 \mathrm{C})$, and to other processes.

First-effect vapor in the second-effect vapor chest gives most of its heat to the juice in the second effect, and so produces second-effect vapor. This process continues down through evaporators 3,4 , and 5 , until the vapor from the last effect is led to a condenser. This condenser maintains the last vapor below atmospheric pressure and consequently at a low temperature. Thus, each evaporator effect acts as a condenser for the preceeding effect. Each succeeding vapor pressure, and of course temperature, is proportionately lower with the lowest vapor pressure in the last effect under control by the barometric condenser.

One pound of steam admitted to the first-effect steam chest evaporates approximately one pound of water from the juice in the effect. One pound of the first vapor thus formed, when admitted to the second-effect steam chest, will evaporate one pound of water from the juice in the second effect. Consequently, one pound of steam admitted to the first-effect evaporator will evaporate approximately five pounds of water in the quintuple-effect evaporator. Evaporation comes from two sources: juice "flash" and condensation of steam or vapor in the chest.

High-pressure steam from the boilers at 255 psia is expanded to exhaust steam pressure, either through turbines or reducing valves, and is used in the first-effect evaporator only. A11 other factory heating uses vapor from the following effects: diffusion juice with third and then second vapor, juice after carbonation with second vapor, and thin juice on its way to the first effect with second vapor then first vapor. 


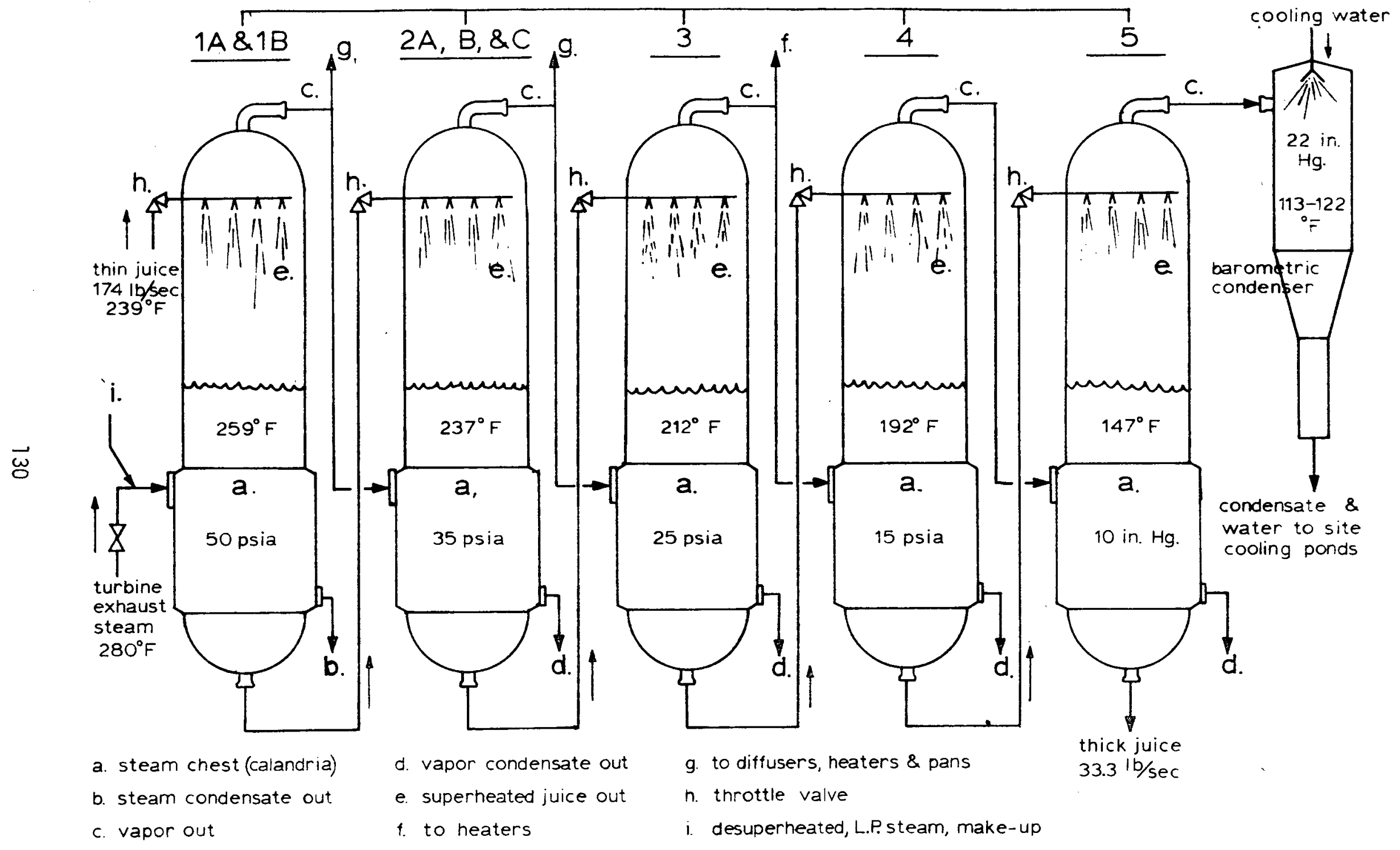

Figure 43. Quintuple-effect evaporators. 


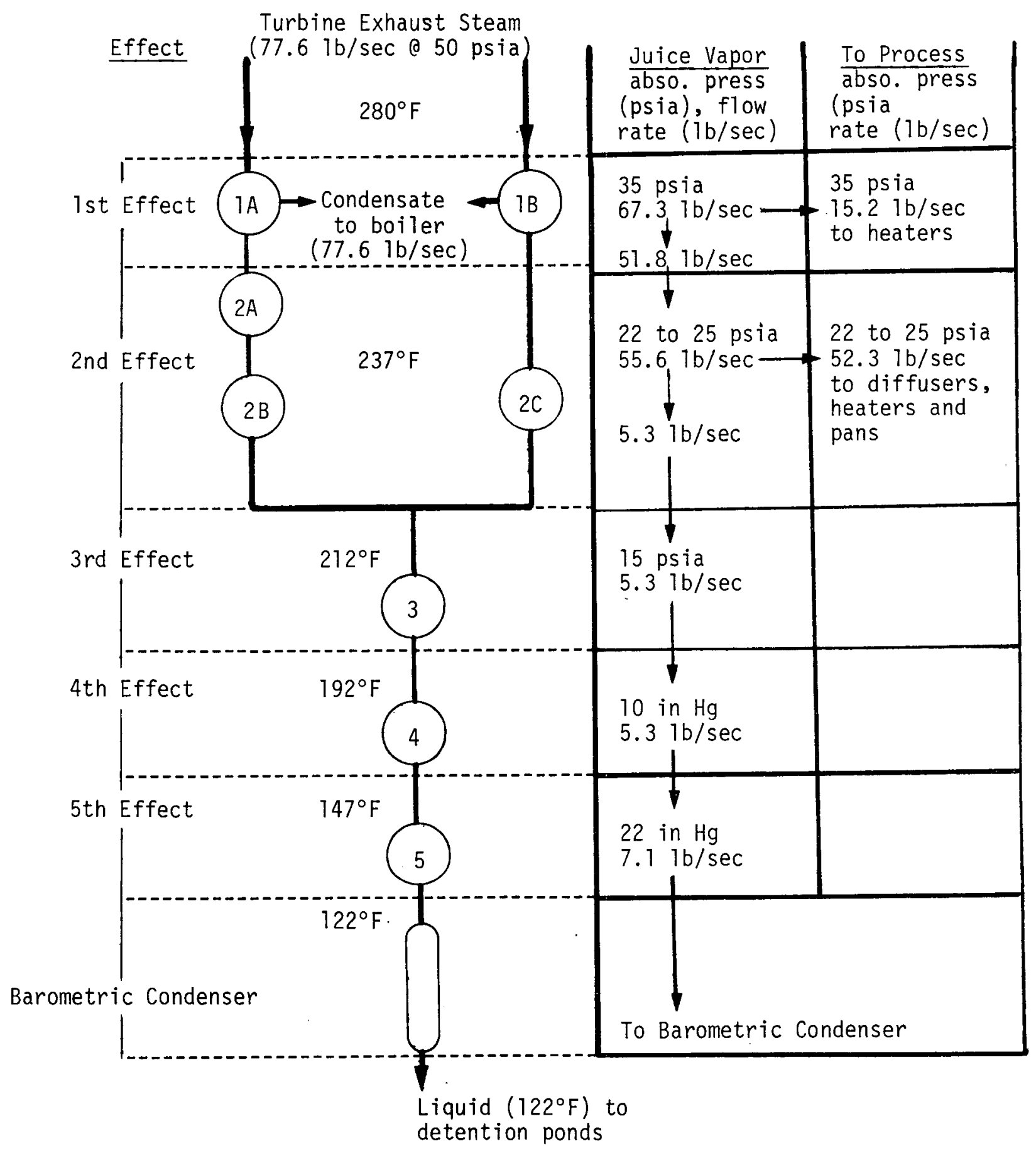

Figure 43A. Quintuple-effect evaporator flow diagram. 
By evaporation the percentage of dissolved solids in the juice is raised from 10 to 15 percent to 50 to 65 percent and the outflow is called thick juice.

\section{4) Ion Exchange}

The role of ion exchange is to exchange $\mathrm{Ca}$ ions with $\mathrm{Mg}$ ions which bind up less sucrose, resulting in increased extraction (less molasses). Ion exchange is accomplished by passing juices through beds of synthetic ion exchange resins. In the 6,600-ton Nyssa plant, with 15 percent sugar in beets, the increase in extraction can increase white sugar production by 240 bags (100 pounds) a day.

\section{5) Crystallization}

Sugar is crystallized by pan boiling in the vacuum pans. The boiling takes place at low pressure and thus low temperature in order to avoid caramelization.

A quantity of juice is boiled in the pan under vacuum, until the juice is supersaturated. The liquor is either shocked to start crystal formation by the addition of a small amount of powdered sugar, or it is seeded at a lower saturation by addition of finely milled sugar in a slurry with isopropyl alcohol.

When crystals are of the desired size and number, they are discharged from the vacuum pan into the mixer which slowly agitates the mass. From the mixer the mass of crystals is fed to centrifugals. The sugar centrifugal is a perforated basket which rotates around a vertical axis at high speed within an outer collector shell. The liquid surrounding the crystals is centrifuged or spun off, and leaves the basket through the perforations.

Following one or two brief washes with pure hot water, the wet white sugar crystals are discharged from the centrifugal basket, and are sent to the dryer or granulator and the cooler. Hot, filtered air is passed through the granulator, and cool, filtered air is passed through the cooler. The granulated sugar is then screened, and either sacked immediately, or stored in bulk bins to await future packaging or bulk delivery.

A three-stage boiling scheme is used. The syrup spun from the third boiling is molasses, which is a by-product. Sugar may be recovered from molasses by the Steffen process. Part of the molasses is added to pulp to be used as livestock feed. 
6) Dried Molasses Beet Pulp

Wet pulp from the diffuser is run to vertical single-screw and horizontal double-screw pulp presses, where the moisture content is reduced from 95 percent to between 76 and 84 percent. After the addition of molasses the pressed pulp is dried to a moisture content of about 10 percent by hot air in a pulp dryer consisting of a horizontal rotating drum. Hot air enters the pulp dryer at $1800^{\circ} \mathrm{F}$ and leaves at $240^{\circ} \mathrm{F}$. The pulp dryer consumes about 10 percent of the total energy produced by the plant.

The pulp is normally made into pellets in which form it is stored and sold for animal feed.

\section{c. Power Production and Energy Requirements}

Sugar processing requires large quantities of low-pressure process steam. The power plant uses a noncondensing steam turbine generator which will exhaust steam at the pressure required for process.

The inlet steam pressure to the turbine is 245 psia and 420 psia absolute, with the back pressure or exhaust at 50 psia. Approximately 110 pounds of steam per second is generated by the coalfired boilers. Energy produced by the boilers is consumed by the following: 75 percent to evaporators, 4 percent to turbines, 6 percent live steam to process, 10 percent to evaporation to form concentrated Steffen Filtrate (CSF) and pulp dryers, and 5 percent to steam venting and losses.

During the 1976 campaign, the three steam turbine generators produced a total 15.3 million kw hr of electrical energy. Table XXI provides a summary of energy used by the factory.

Bituminous coal from the Wyoming fields is the fuel for boilers. The company has a 25-year agreement with the coal suppliers, of which 12 years remain.

During the 1976 operating season ( 130 days), boilers produced $1.67 \times 10^{12}$ Btu of thermal energy by burning 80,000 tons of coal. Boiler efficiency is rated at 76 percent and the heat content of the coal is $664 \mathrm{Btu} / \mathrm{lb}$. Coal cost was approximately $\$ .09$ per therm. Approximately $1.20 \times 10^{6} \mathrm{Btu}$ are required to produce a 100 -pound bag of sugar.

\section{d. Geothermal Application}

Table XXI shows the steam balance from the boilers. The turbine generators consume approximately 4 percent and evaporators 75 percent of the total steam supplied. However, as has been discussed in section $C$, the evaporators utilize turbine exhaust steam. 
TABLE XXI

STEAM BALANCE

Application

1. Turbines

2. Evaporators

3. CSF \& pulp dryers

4. Live steam

5. Venting \& losses

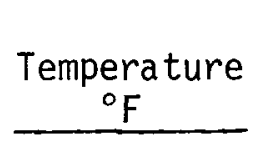

$403 \& 262$

280

424

403

varies
Absolute

pressure psia

$245 \& 420$

40

55

245

varies

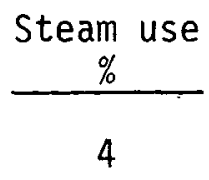

75

10

6

5

The high use of energy in the evaporation process makes it an attractive candidate for conversion to geothermal energy. Even though some of its energy needs are currently supplied from waste heat generated by electricity production, a large part of the energy loads of the plant could be satisfied if the evaporation process was to be adapted to use of geothermal energy.

Two ways of doing this are apparent. One method would use the total flow (Figure 44) of geothermal fluid through the first effect. The second alternative would employ only steam flashed from the geothermal fluid in the first effect, the water fraction of the flow being discarded. Both methods have been investigated and will be discussed, but the latter was considered the more attractive scheme and costs for the conversion were based on the assumption that it would be used.

Total Flow Method

A prime consideration in using this method is the heat transferring capability of the first effect when the hot side fluid is predominantly water rather than steam, which is now used. An estimate of this capability follows.

Present Overall Heat Transfer Coefficient

The first effect actually consists of two vertical-tube, shelland-tube heat exchangers containing 8,174 and 3,938 tubes, respectively, having a 1.25 -inch 0. d. The general configuration of these exchangers is shown in Figure 45. As currently operated, saturated steam at $280^{\circ} \mathrm{F}$ and $49.74 \mathrm{psia}$ is condensed at a rate of $77.44 \mathrm{lb} / \mathrm{sec}$ to deliver energy at a rate of $71,518 \mathrm{Btu} / \mathrm{sec}$. On the cold side, juice at a lower pressure enters at $239^{\circ} \mathrm{F}$ and is 


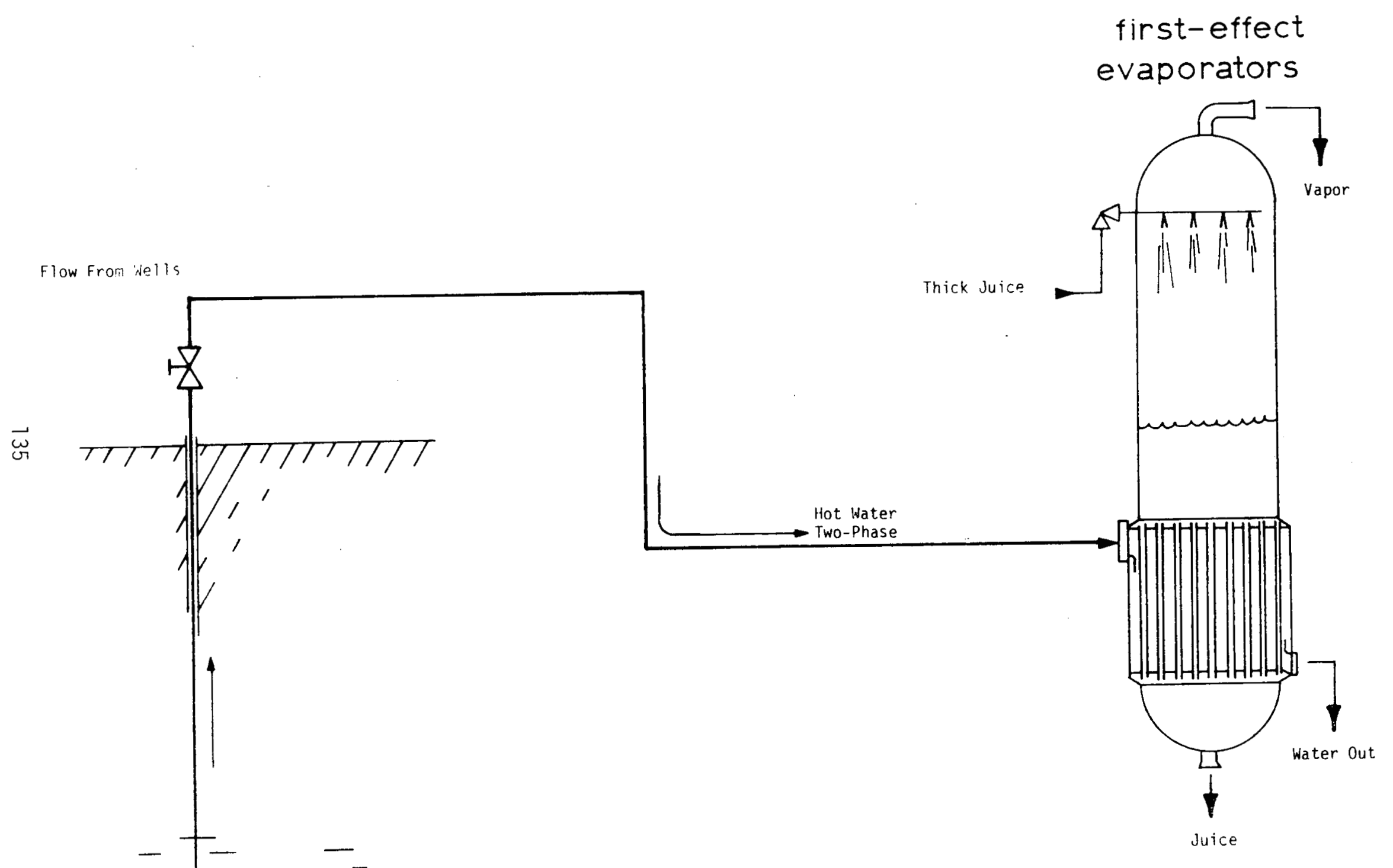

Figure 44. Total Flow Method 


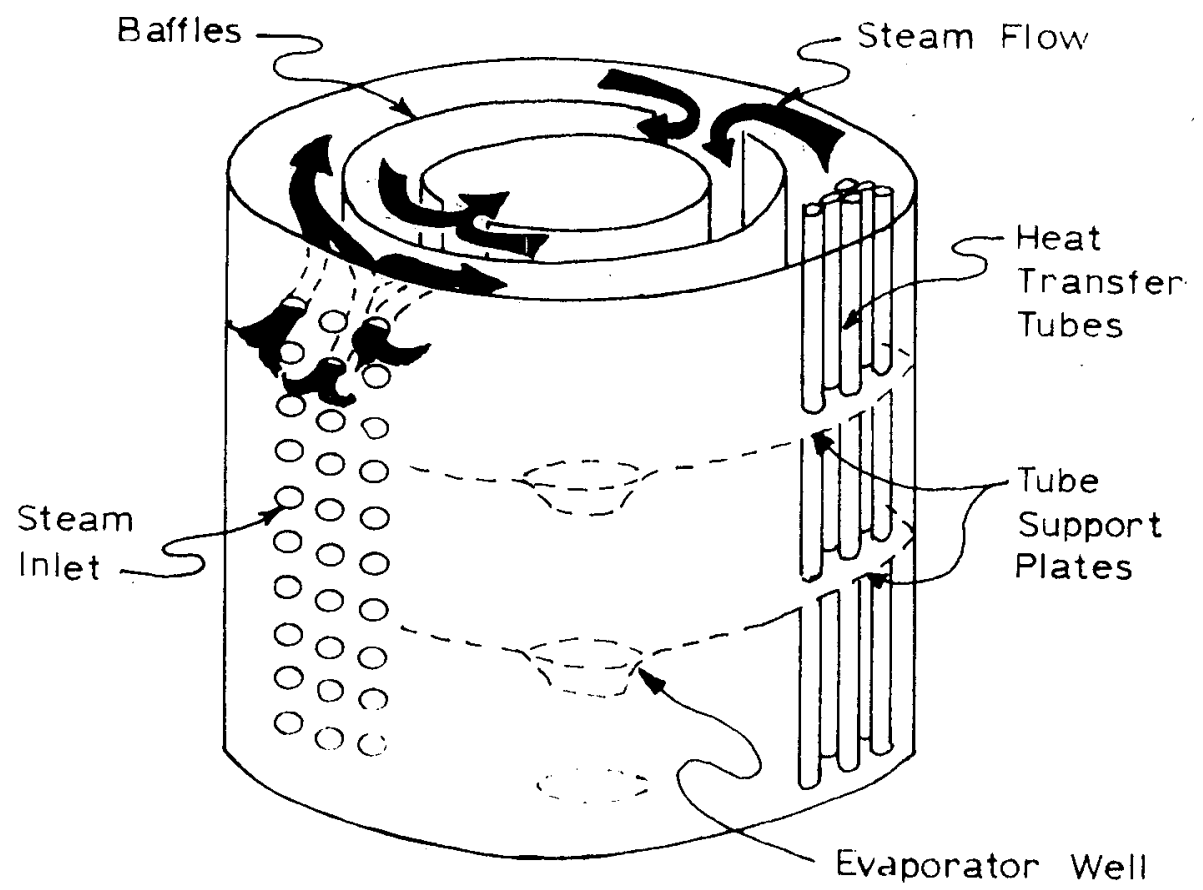

Figure 45. Evaporator heat exchanger configuration.

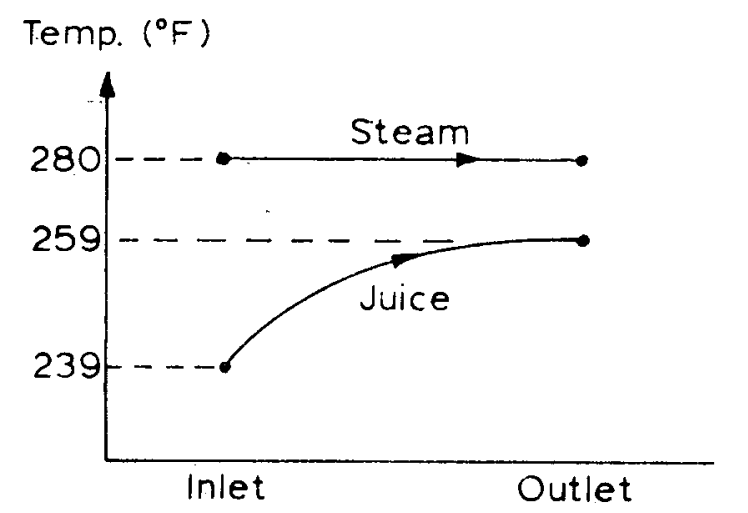

Figure 46. Temperature profile of first-effect evaporator heat exchanger. 
heated to saturation at $259^{\circ} \mathrm{F}$. It is then vaporized at a rate of $67.1 \mathrm{lb} / \mathrm{sec}$. The total energy, $Q$, delivered to the juice in the first effect is $66,571 \mathrm{Btu} / \mathrm{sec}$. The temperature profile in the first effect is shown in Figure 46; the corresponding $10 \mathrm{~g}$ mean temperature difference, $\Delta T \mathrm{Tm}$, is $30^{\circ} \mathrm{F}$. As the total (outside) heat transfer area, $A$, of the first effect is $35,926 \mathrm{ft}^{2}$, the overall (outside) heat transfer coefficient is:

$$
U_{\text {steam }}=\frac{Q}{A \Delta T m}=210 \frac{B t u}{h r-\mathrm{ft}^{\circ} \mathrm{F}}
$$

New Overal1 Heat Transfer Coefficient

The general expression for $U$ is:

$$
\begin{aligned}
& U=\frac{1}{\frac{1}{h_{0}}+R_{f_{0}}+\left[R_{t}+R_{f_{j} \cdot \frac{A 0}{A i}}+\frac{1}{h_{j}} \frac{A_{0}}{A \dot{i}}\right]} \\
& \text { where } A i=\text { inside tube surface area } \\
& \text { Ao }=\text { outside tube surface area } \\
& \text { hi }=\text { inside film coefficient } \\
& \text { ho }=\text { outside film coefficient } \\
& R_{f_{j}}=\text { inside fouling resistance } \\
& R_{f_{0}}=\text { outside fouling resistance } \\
& R_{t}=\text { tube resistance }
\end{aligned}
$$

All of the bracketed terms in the denominator will be essentially unchanged when the current shell fluid (steam) is replaced by geothermal fluid. The sum of these terms may be evaluated, once $h_{0}$ and $R_{f_{0}}$ are estimated when the outside fluid is steam, using:

$$
\underline{\bar{x}} \Delta\left[R_{t}+\cdots+\frac{1}{h i} \frac{A_{0}}{A i}\right]=\frac{1}{U_{\text {steam }}}-\left[\frac{1}{h o}+R_{f_{0}}\right]_{\text {steam }}
$$

Assuming film-type condensation $h_{0_{\text {steam }}}$ is estimated from:

$$
h=\Phi_{f} \times A_{1} \times\left(\frac{4^{\Gamma}}{\mu f}\right)-1 / 3
$$


where $A_{T} 1.47$ (for vertical tubes)

$$
\begin{aligned}
\Phi_{f} & =\frac{h_{f^{3} \rho f^{2} g}}{\mu^{2} f} \\
h_{f} & =\text { thermal conductivity of condensate at film temperature } \\
\rho f & =\text { density of condensate at } f i 1 m \text { temperature } \\
g & =\text { acceleration of gravity } \\
\mu f & =\text { absolute viscosity of condensate at film temperature } \\
\Gamma & =\frac{\text { mass flow rate of condensate per tube }(1 \mathrm{~b} / \mathrm{hr})}{\pi \text { tube diameter }(\mathrm{ft})}
\end{aligned}
$$

and

An approximate average condensate flow rate is established next. Assuming the steam flow rate in each exchanger is proportional to the number of steam admission holes in the exchanger (124 and $84)$, the condensate mass flows are, respectively, $16.6 \times 10^{4} \mathrm{lb} / \mathrm{hr}$ and $11.3 \times 10^{4} \mathrm{lb} / \mathrm{hr}$. The number of tube segments (the tubes are divided into segments by the support plates) in the larger exchanger is 32,696 and 7,876 in the smaller one. The condensate mass flow rates for the larger and smaller exchangers are 5.08 and 14.4 , respectively. A flow-rate weighted average value is then:

\section{$8.9 \mathrm{lb} / \mathrm{hr}$}

and

$$
\Gamma=\pi \times \frac{8.9}{1.25} \times 12=27.2 \frac{\mathrm{lb}}{\mathrm{hr} \mathrm{ft}}
$$

At the mean film temperature of $265^{\circ} \mathrm{F}, \mu_{f}=.517 \frac{1 \mathrm{~b}}{\mathrm{hr}}$, and
$\Phi_{\mathrm{f}}=6918$, giving an outside film coefficient of :

$$
h_{0}=1710 \frac{\mathrm{Btu}}{\mathrm{hr} \mathrm{ft}^{2}{ }^{\circ} \mathrm{F}}
$$

A reasonable value for the outside fouling resistance is:

$$
\text { (2) } 0.0005 \frac{\mathrm{hr} \mathrm{ft}^{2}{ }^{\circ} \mathrm{F}}{\mathrm{Btu}}
$$

So finally:

$$
\underline{X}=\left[R_{t}+\cdots+\frac{1}{h_{i}} \frac{A 0}{a i}\right]=\frac{1}{210}-\left[\frac{1}{1710}+0.0005\right]=0.0037 \frac{\left(h_{r} \mathrm{ft}^{2}{ }^{\circ} F\right)}{B t u}
$$


A reasonable value for the outside fouling resistance to be expected with geothermal fluid on the shell side is felt to be:

$$
\left({ }^{2}\right),\left({ }^{3}\right) 0.003 \frac{\mathrm{hr} \mathrm{ft}^{2}{ }^{\circ} \mathrm{F}}{\mathrm{Btu}}
$$

The outside film coefficient for this case may be found from (1):

$$
h_{0}=370\left(1+0.006 \times T_{f}\right) \frac{V_{\max }^{0.6}}{D_{0} 0.4}
$$

where $T_{f}=$ average film temperature, ${ }^{\circ} \mathrm{F}$

$$
V_{\max }=\text { maximum shell side fluid velocity, } \mathrm{ft} / \mathrm{sec}
$$

and

$$
D_{0}=\text { outside tube diameter, inches }
$$

$V_{\max }$ may be approximated after the quantity of geothermal fluid required is established. It is assumed this will be available at a temperature of $327^{\circ} \mathrm{F}$ and a quality of 8.3 percent $\left({ }^{4}\right)$, and that the exchanger pinch point temperature difference is $20^{\circ} \mathrm{F}$, as before. The energy extracted under these conditions from the geothermal fluid is $122 \mathrm{Btu} / \mathrm{lb}$. Thus, to supply the same energy $(71,518 \mathrm{Btu} / \mathrm{sec})$ as is currently obtained from steam, the geothermal fluid flow rate must be $5861 \mathrm{~b} / \mathrm{sec}\left(10.1 \mathrm{ft}^{3} / \mathrm{sec}\right.$, approximately). From the tube bundle and baffle geometry of the firsteffect exchangers, the average maximum velocity of the geothermal fluid can now be estimated to be about $0.5 \mathrm{ft} / \mathrm{sec}$. Taking the film temperature to be $276^{\circ} \mathrm{F}$ the outside film coefficient for the geothermal fluid case is:

$$
h_{\text {og.f. }}=370(1+0.006 \times 276) \frac{.5}{1.25}{ }^{0.6} 0.4=\frac{B t u}{h r f^{2}{ }^{\circ} F}
$$

For the geothermal case, then:

$$
U=\frac{1}{\frac{1}{593}+0.003+0.0037}=119 \frac{\mathrm{Btu}}{\mathrm{hr} \mathrm{ft}^{2}{ }^{\circ} \mathrm{F}}
$$

Since $\Delta \mathrm{Tm}=47^{\circ} \mathrm{F}$ with geothermal fluid on the shell side,

$$
Q=119 \times 35,926 \times 47=2 \times 10^{8} \mathrm{Btu} / \mathrm{hr},
$$

which is about 13 percent less than the current heat transfer rate.

The uncertainties involved in this calculation only allow one to conclude that geothermal fluid can be used in place of steam to operate the first effect with the possible necessity of using some additional heat exchanger capacity. 


\section{Flashed Steam Method}

The geothermal fluid is again assumed to be available at $327^{\circ} \mathrm{F}$ and 8.3 percent quality, fixing the enthalpy at $369 \mathrm{Btu} / \mathrm{lb}$. If the fluid is throttled down to a pressure of about 49 psia some of it will flash to steam at $280^{\circ} \mathrm{F}$. Specifically, .125 $1 \mathrm{~b}$. of steam will be available for each pound of geothermal fluid that is throttled. Further, this steam will be exactly at the conditions of the steam currently used. So, to obtain $77.4 \mathrm{lb} / \mathrm{sec}$ of steam, the quantity currently used, the quantity of geothermal fluid required would be about $620 \mathrm{lb} / \mathrm{sec}$. It is estimated that seven self-flowing wells would provide this flow rate, and two injection wells would be adequate for disposing of the waste.

A general plan for implementing this scheme is illustrated in Figure 47. All wells are interconnected so they feed a common 1 ine to the steam flasher or their outputs can be directly disposed of via the injection wells. Provision is also made for disposing of the well flow in a surface pond through a silencer unit.

Water separated out at the steam flasher is routed to the disposal lines where it joins the condensate returning from the plant. Some of the condensate may be diverted to the flasher for the purpose of scrubbing the flashed steam. The 22-inch steam delivery 1 ine and the 6 -inch condensate return line run from the well field to the plant in a reinforced concrete conduit, as illustrated in Figure 48. The removable top of the conduit would be at ground leve1. The 1,200-foot long path of the pipeline is shown in Figure 48, which is adapted from an aerial photograph of the plant and surroundings. The portion of the pipeline near the plant is elevated on stanchions about 20 feet above ground.

\section{e. Economic Analys is}

The economic assessment of the Amalgamated Sugar Company presents several factors unique to this company. In 1964, Amalgamated obtained a 25-year coal contract at a price of $\$ 10$ per ton. With 12 years remaining on this contract, the inflation rate for the next 12 years wil1 consist of labor and transportation which is currently $\$ 10.75$ per ton, inflating at a rate of 7.5 percent annual1y. Amalgamated currently uses 615 tons per day for 120 days per year. Also in converting to geothermal energy, Amalgamated could salvage their pollution control equipment, which has a current book value of $\$ 2$ million. It is estimated that this equipment would salvage for about $\$ 650,000$ after removal costs, providing a loss of $\$ 1,350,000$ on the sale of this equipment and a tax reduction of $\$ 648,000$. Further, Amalgamated could reduce maintenance costs by $\$ 6,500$ annually that are currently inflating at a rate of 6 percent per annum. The maintenance force could also be reduced from five to two men resulting 


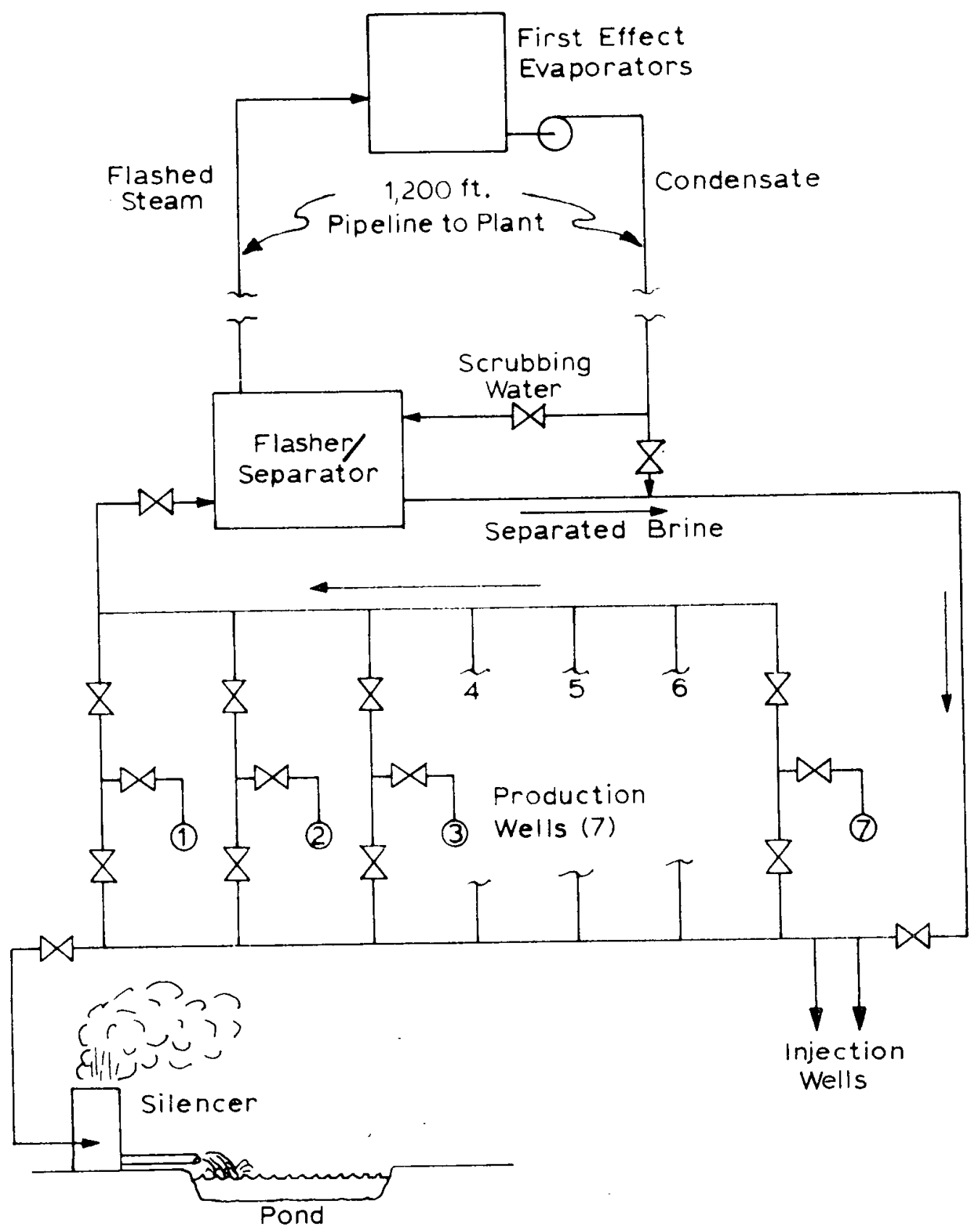

Figure 47. Amalgamated Sugar Company Flow Diagram for Geothermal Conversion 


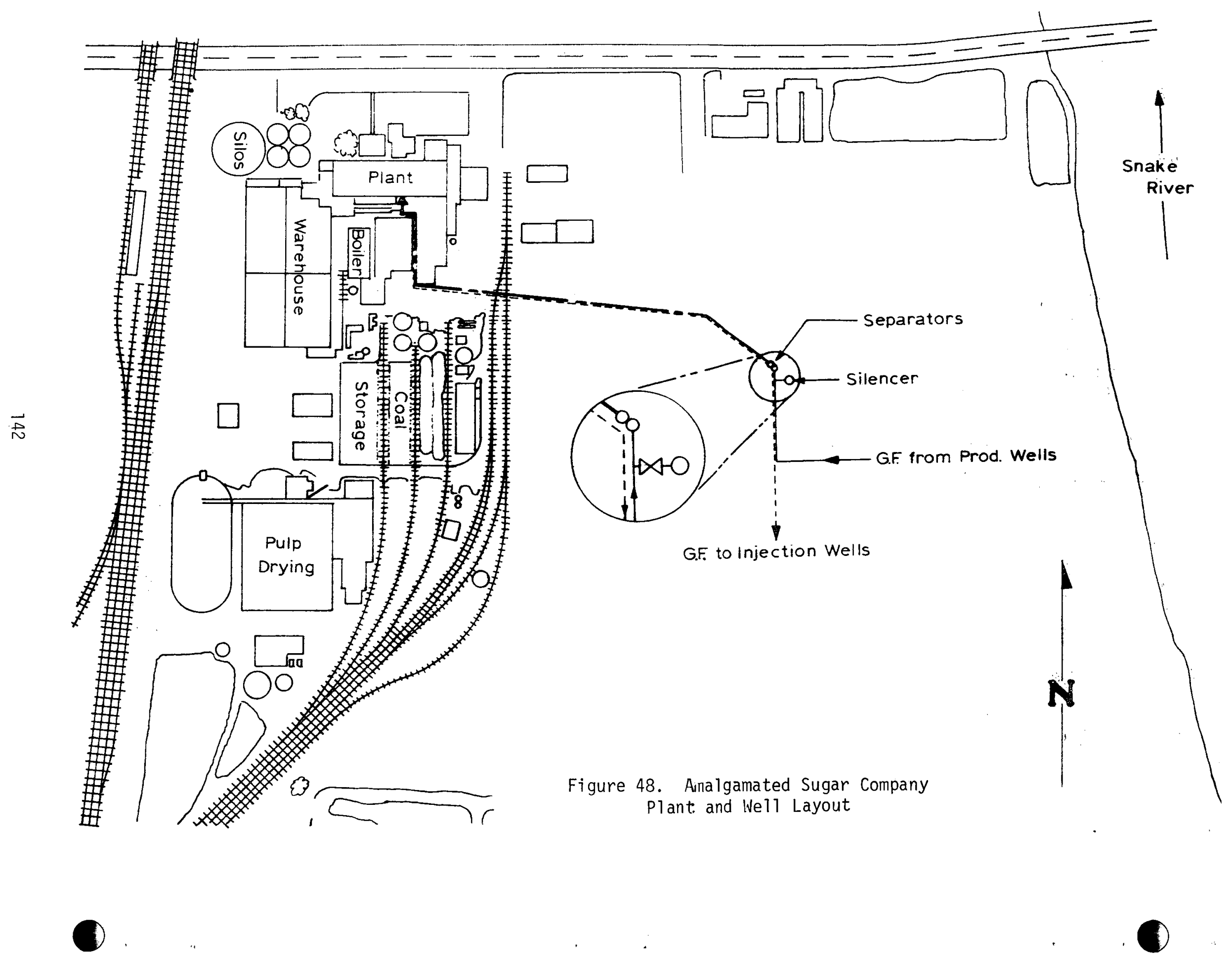


in an annual savings of three men at $\$ 6.50 / \mathrm{hr} / \mathrm{man}, 8$ hours per day, 120 days per year for a total annual savings of $\$ 18,720$. These costs are also inflating at 6 percent per annum.

Costs of electrical power would decrease by $\$ 3,900$ per year due to shut down of pollution control equipment and would increase by $\$ 166,000$ because of shutting down the steam turbines which currently produce $1,530,000 \mathrm{kWh}$ annually. The geothermal conversion would add $136 \mathrm{kWh}$ for the operation of two 70-hp pumps on the return wells plus a 15-hp condensate pump operating at 85 percent efficiency. The total annual cost for geothermal operation then, is $136 \mathrm{kWh}$ at $.01085 / \mathrm{kWh}$ for $24 \mathrm{hr} /$ day 120 days/year equals $\$ 4,250$. Therefore, total annual power costs for the geothermal system are:

$$
\begin{array}{lc}
\text { Pollution control shutdown } & \left(\begin{array}{r}
3,900) \\
166,000 \\
\text { Turbine shutdown }
\end{array}\right. \\
\text { Geothermal operation } & \begin{array}{l}
4,250 \\
\end{array} \\
\hline 166,350
\end{array}
$$

The cost of electrical energy is assumed to inflate at 8.5 percent through 1986 and 7.38 percent thereafter.

\begin{tabular}{|c|c|c|c|c|c|}
\hline Year & $\begin{array}{c}\text { A } \\
\text { Projected } \\
\text { annual cost } \\
\text { of delivered } \\
\text { coal } \\
\end{array}$ & $\begin{array}{l}\text { B } \\
\text { Pollution } \\
\text { control and } \\
\text { maintenance } \\
\text { cost } \\
\end{array}$ & $\begin{array}{c}\text { Increased } \\
\text { power } \\
\text { costs } \\
\end{array}$ & \begin{tabular}{c}
\multicolumn{1}{c}{ D } \\
Geothermal \\
system \\
annual \\
maintenance \\
\end{tabular} & $\begin{array}{c}\text { E } \\
\text { Total annual } \\
\text { savings before } \\
\text { depletion and } \\
\text { taxes. A+B- }(C+D) \\
\end{array}$ \\
\hline $\begin{array}{l}1978 \\
1979 \\
1980 \\
1981 \\
1982 \\
1983 \\
1984 \\
1985 \\
1986 \\
1987\end{array}$ & $\begin{array}{r}\$ 1,590,851 \\
1,654,814 \\
1,723,576 \\
1,797,494 \\
1,876,956 \\
1,962,378 \\
2,054,207 \\
2,152,922 \\
2,259,041 \\
2,373,119\end{array}$ & $\begin{array}{r}\$ 25,220 \\
26,733 \\
28,337 \\
30,037 \\
31,840 \\
33,750 \\
35,775 \\
37,922 \\
40,197 \\
42,609\end{array}$ & $\begin{array}{r}\$ 166,350 \\
180,490 \\
195,831 \\
212,477 \\
230,538 \\
250,133 \\
271,395 \\
294,463 \\
319,493 \\
346,649\end{array}$ & $\begin{array}{r}\$ 8,000 \\
8,480 \\
8,989 \\
9,528 \\
10,100 \\
10,706 \\
11,348 \\
12,029 \\
12,751 \\
13,516\end{array}$ & $\begin{array}{r}\$ 1,441,721 \\
1,492,578 \\
1,547,093 \\
1,605,526 \\
1,668,158 \\
1,735,289 \\
1,807,239 \\
1,884,352 \\
1,966,994 \\
2,055,563\end{array}$ \\
\hline
\end{tabular}

The following table presents a ten-year projection of all operating costs at their respective inflation rates.

TABLE XXII

OPERATING COSTS

A depletion allowance for savings from geothermal conversion is anticipated as follows:
1978 through $1980-22$ percent
1983 - 16 percent
1981 - 20 percent
1982 - 18 percent
1984 on - 15 percent

This depletion allowance is subtracted from the total annual savings to lower federal taxes due to lower energy costs. 


\begin{tabular}{|c|c|c|c|c|}
\hline Year & Percent & $\begin{array}{r}\text { TABLE XX } \\
\text { Oper } \\
F \\
\text { Depletion } \\
\text { allowance } \\
\text { indicated.\% } \\
\text { of column E } \\
\end{array}$ & $\begin{array}{l}\text { (continued) } \\
\text { ng Costs } \\
G \\
\text { Tax increase } \\
\text { due to } \\
\text { reduced costs } \\
(E-F) .48 \\
\end{array}$ & $\begin{array}{c}\text { After tax } \\
\text { cash inflow } \\
\text { from operations } \\
E-G \\
\end{array}$ \\
\hline $\begin{array}{l}1978 \\
1979 \\
1980 \\
1981 \\
1982 \\
1983 \\
1984 \\
1985 \\
1986 \\
1987\end{array}$ & $\begin{array}{l}22 \\
22 \\
22 \\
20 \\
18 \\
16 \\
15 \\
15 \\
15 \\
15\end{array}$ & $\begin{array}{r}\$ 317,179 \\
328,367 \\
340,360 \\
321,105 \\
300,268 \\
277,646 \\
271,086 \\
282,653 \\
295,049 \\
308,334\end{array}$ & $\begin{array}{r}\$ 539,780 \\
558,821 \\
579,232 \\
616,522 \\
656,587 \\
699,669 \\
737,354 \\
768,816 \\
802,534 \\
838,670\end{array}$ & $\begin{array}{r}901,941 \\
933,757 \\
967,861 \\
989,004 \\
1,011,571 \\
1,035,621 \\
1,069,886 \\
1,115,536 \\
1,164,460 \\
1,216,893\end{array}$ \\
\hline
\end{tabular}

TABLE XXIII

AMALGAMATED SUGAR COMPANY

Conversion Costs for Geothermal Energy

\section{Item}

Steam separator

Silencer

Wellhead valving a 25,000/well

9 wells required ( 7 supply, 2 return)

Return well pumps $70 \mathrm{hp}$ a 40,000 each

Condensate pump $15 \mathrm{hp}$

Piping (includes installation) 1,200 feet $22^{\prime \prime}$ and 8" Trenching

Power line

Transformer

Engineering a 10\%

Contingency o $10 \%$
Tangible

$\$ 57,400$

18,000

225,000

80,000

500

168,400

54,000

19,300

35,000

65,760

65,760

$\$ 789,120$

Intangible

Drill 9 wells

Contingency $20 \%$

$\$ 5,121,000$

$1,024,200$

$\$ 6,145,200$

$\$ 6,934,320$

TOTAL CAPITAL INVESTMENT

Tangible asset costs in the first year total $\$ 789,120$. Assuming a ten-
year 1 ife and a 10 percent salvage value, annual straight-1ine depreciation would be $\$ 71,021$ providing a cash inflow of $\$ 34,090$ annually in reduced taxes. 
At the end of the first year additional cash inflow would result as follows:

Expensing intangible cost of $\$ 6,145,200$ provides $\$ 2,949,696$

Loss on sale of pollution equipment

$1,350,000$

648,000

Cash received from sale of equipment

650,000

Investment tax credit o $20 \%$

$(789,120)$

157,824

$\$ 4,405,520$

Depreciation (straight line)

34,090

After-tax inflow from operations

901,941

Total first-year cash inflow

$\$ 5,341,551$

Total capital investment at year zero

$\$ 6,934,320$

Ten-year projection of cash inflow after taxes:

\begin{tabular}{|c|c|c|}
\hline Year & Cash inflow & $\begin{array}{c}\text { Discounted } \\
020 \% \\
\end{array}$ \\
\hline $\begin{array}{l}1978 \\
1979 \\
1980 \\
1981 \\
1982 \\
1983 \\
1984 \\
1985 \\
1986 \\
1987\end{array}$ & $\begin{array}{r}\$ 5,341,551 \\
967,847 \\
1,001,951 \\
1,023,094 \\
1,045,661 \\
1,069,711 \\
1,103,976 \\
1,149,626 \\
1,198,550 \\
1,250,983\end{array}$ & $\begin{array}{r}\$ 4,451,293 \\
672,116 \\
579,833 \\
493,390 \\
420,228 \\
358,244^{\star}\end{array}$ \\
\hline
\end{tabular}

Present worth of cash inflows (a) $27 \%$

\begin{tabular}{rr}
$\$ 4,108,885$ & $\$ 4,205,946$ \\
572,691 & 600,066 \\
456,054 & 489,142 \\
358,214 & 393,279 \\
281,627 & 316,499 \\
221,619 & 254,944 \\
175,937 & 207,173 \\
140,932 & 169,874 \\
113,023 & 139,451 \\
90,744 & 114,608 \\
\hline$\$ 6,519,725$ & $\$ 6,890,982$
\end{tabular}

*Payback occurs in sixth year (a $20 \%$

$\mathrm{ROI} \approx 26 \%$ 
3. Ore-Ida Foods, Inc., Ontario, Oregon

\section{a. Introduction}

Ore-Ida Foods, Inc., a division of H. J. Heinz Company, is located on the Oregon-Idaho border near the Snake, River at Ontario, Oregon. Their major product is frozen potato products processed from August 1 through June 31 . There is an additional seasonal processing of corn and onions for seven weeks and six months respectively. This plant processes over two million pounds of potatoes per day resulting in over one million pounds of frozen potato products.

The plant occupies $187,000 \mathrm{ft}^{2}$ which includes a 17 processing and package areas. Two natural gas-fired boilers supply an average of $120,0001 \mathrm{~b} / \mathrm{hr}$ steam to process with 40 percent returned as a condensate. A11 processes except frying utilize direct injection of steam at 100 psig. Saturated frying employs heat exchangers and steam at $275 \mathrm{psig}$. The fryers consume 45 percent of the energy of the plant and since the return temperature is greater than $300^{\circ} \mathrm{F}$, the assumed geothermal water supply temperature, 55 percent of the process energy requirements can be supplied by geothermal energy.

The energy consumption for the 1976 calendar year was:

1. Heating: 290,000 therms per year at a cost of $\$ 65,075$

2. Processing: Natural gas- $-4,394,326$ therms at a cost of $\$ 880,904$

$$
0 i 1--816,081 \text { gallons at a cost of } \$ 297,870
$$

Natural gas availability is dependent upon weather conditions and gas utility contracts. According to company spokesmen, it appears that the trend for industrial fuel is away from natural gas and toward fuel oils and possibly coal. At present the availability of fuel oil appears to be quite solid and will continue to be so in the near future.

\section{b. Process Steps}

To understand the potato process methods and energy requirements for each step, the accompanying composite flow sheet, Figure 49, and following description from an ore-Ida publication is used to explain potato processing at the ontario plant.

There are two prime french-fry potato lines and several by-product lines. Potatoes for processing are conveyed to a battery of scrubbers and then moved into a preheater, which warms the potatoes and softens the peel, making it easier to remove the skin. The potatoes are then chemically peeled by a 15 percent lye solution. 


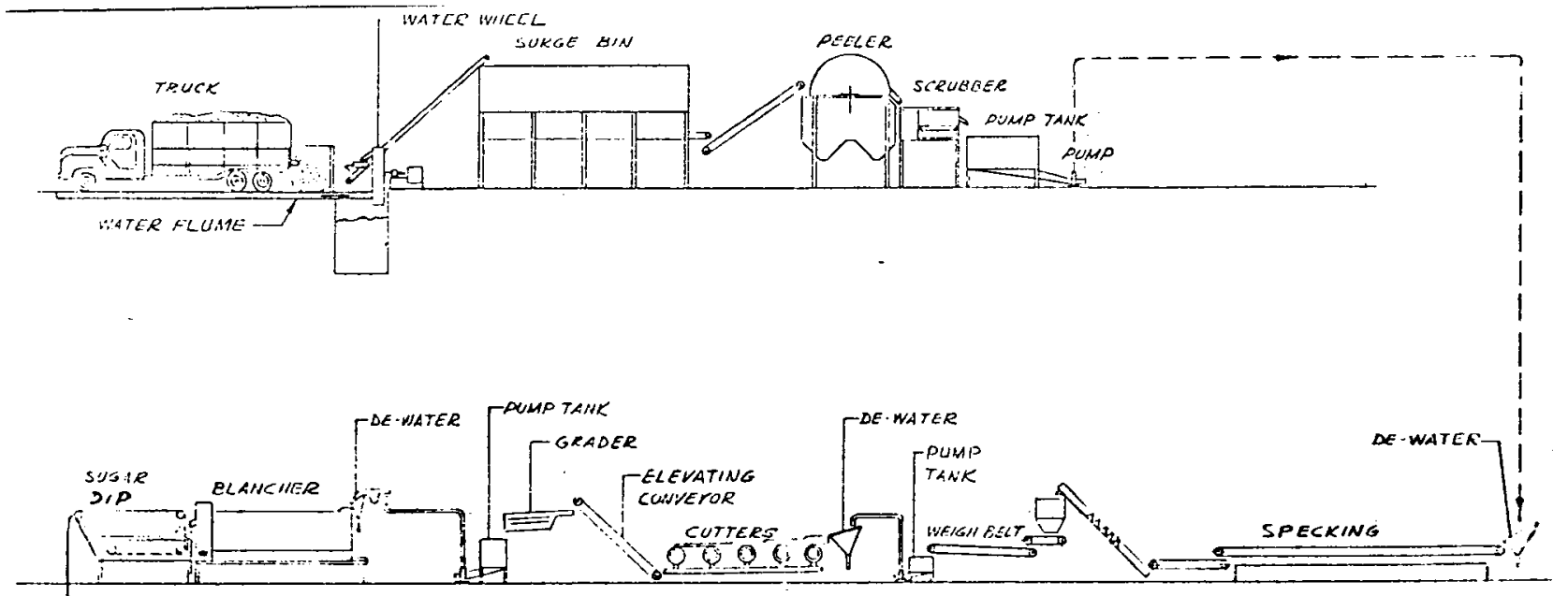

Figure 49. Ore-Ida Foods, Inc.

Schematic Process Flow Chart

Heat for peeling, 24,460,000 Btu/hr is supplied by the direct injection of steam at $100 \mathrm{psig}$, maintaining the solution at a temperature of $140^{\circ}$ to $175^{\circ} \mathrm{F}$.

Upon leaving the chemical peeler, the potatoes are conveyed to a battery of scrubbers, where the peeling is removed. After the scrubbers, the peeled potatoes are subjected to another washing process and then conveyed to the trim tables by pumping. The peeling removed by the scrubbers is pumped to a holding tank and sold as cattle feed.

After the potatoes are trimmed for defects, the product is conveyed to cutter areas where a bank of Urschel cutters cut them to the desired style of french fries. Shakers sort the product 
into appropriate lengths. Small lengths are separated and then processed into hash browns or tator tots. All processing equipment in the plant is made of stainless steel.

The properly trimmed and sized french fries are then carried by gravity to the blanching system on the floor below.

After blanching, the potatoes are dewatered and fed through a sugar drag, which adds a slight amount of dextrose to the surface of the potato, which will impart a golden color when the potatoes are fried. They then pass through a dryer which removes the surface moisture prior to a two-stage frying process. The first stage cooks the product more completely, while the second stage gives it the golden color. The oil in the fryers is heated to $375^{\circ} \mathrm{F}$ by heat exchangers receiving steam at $275 \mathrm{psig}$. The frying process requires 43,135,000 Btu/hr. All fryers were designed and built to Ore-Ida specifications to produce the desired results.

Cleanup, miscellaneous use and plant heat requires about $2,620 \mathrm{lb} / \mathrm{hr}$ of steam, or $2.55 \times 106 \mathrm{Btu} / \mathrm{hr}$. The shorter pieces which have been delegated for the making of tater tots go into a water blancher, then to cutters to be diced, and finally to a mixer, where flavoring ingredients are added.

Freezing of the products is Individual Quick Freeze. (IQF) in Lewis continuous freezing systems powered by Sullair and Mycom compressors. Freezing temperatures are maintained at a constant $-30^{\circ} \mathrm{F}$.

The products, 13 different varieties, are now ready for packaging. They are again mechanically sized and hand-sorted before they are fed onto exact portion scales and the polybags are.filled.

Product pours out of the plant 24 hours a day, engaging three shifts of workers, a total of 900 people, and the pace continues 11 months per year.

\section{c. Energy Requirements}

The heat consumption rate, which largely determines the extent of the geothermal resource required, totals 106,545,000 Btu/hr. This includes all potato processing and plant heating. Of this amount, 43,135,000 Btu/hr are used in the frying process. As has been mentioned, the anticipated resource temperature of $300^{\circ} \mathrm{F}$ precludes the direct use of geothermal energy for frying, which is at $375^{\circ} \mathrm{F}$. However, the remaining $63,410,000 \mathrm{Btu} / \mathrm{hr}$ can readily be satisfied geothermally. (The energy needed for the 2,300 tons of refrigeration used for freezing at $-30^{\circ} \mathrm{F}$ has not been considered for replacement by geothermal energy due to the advanced state-ofthe-art required for obtaining such low temperatures.) 
To avoid any possible contamination of the product by the geothermal fluid, or the need for treatment of the fluid, energy is supplied to the process via intermediate heat exchangers. The geothermal fluid passing through these exchangers will transfer energy to a secondary fluid, primarily water, which delivers the energy to the process. The secondary fluid, circulating in a closed system, then returns to the intermediate heat exchanger to be reheated.

The processes to be supplied by the geothermal resource are distinguished in Table XXIV by their function and temperature requirements. The peeling process involves three distinct steps calling for input temperatures of $250^{\circ}, 200^{\circ}$ and $150^{\circ} \mathrm{F}$. The hot blanch process uses an input temperature of $200^{\circ} \mathrm{F}$ and the warm blanch requires $150^{\circ} \mathrm{F}$. Heating of the hot water used for various functions also calls for $150^{\circ} \mathrm{F}$ as does the plant heating system.

TABLE XXIV

Heat Loads and Secondary Fluid Temperatures

Function
Peel ing
Peel ing
Peel ing
Hot blanch
Warm blanch
Water heating
Plant heat

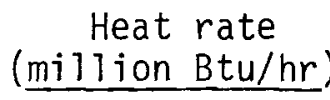

4.12

5.63

14.6

16.52

8.92

2.62

11.00

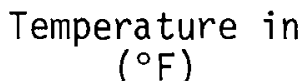

260

200

150

200

150

150

150
Temperature out $\left({ }^{\circ} \mathrm{F}\right)$

200

150

100

100

100

50

100

\section{d. Geothermal Application}

With an anticipated temperature drop of $170^{\circ} \mathrm{F}$ for the geothermal fluid used to supply the $63.4 \mathrm{milli}$ ion Btu/hr needed for processing, roughly $370,000 \mathrm{lb} / \mathrm{hr}$ will be required. This should be readily available from two wells, with adequate margin for load variation or delivery rate fluctuation. The wells would be pumped to minimize temperature losses. A third well would be required for injection of the waste fluid.

Figure 50 suggests one possible routing of the geothermal fluid through the intermediate hot exchangers for maximum extraction of energy. Energy requirements for the high-temperature $\left(200^{\circ} \mathrm{F}\right.$ or more) processes are satisfied by dropping the geothermal fluid temperature from $300^{\circ} \mathrm{F}$ to $190^{\circ} \mathrm{F}$. The lower-temperature processes are then supplied partially by this cooled-off geothermal fluid and partially by fresh geothermal fluid. 


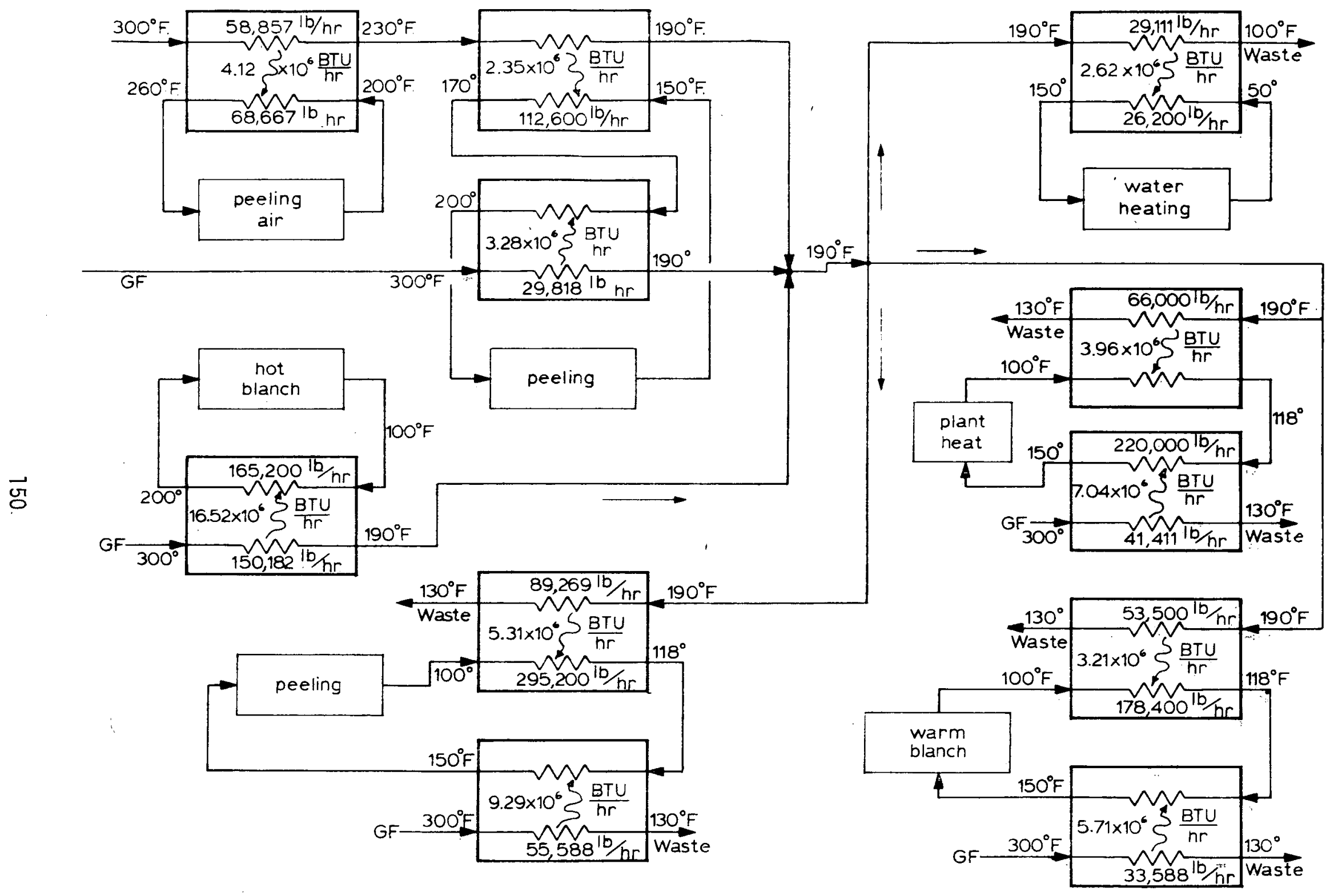

Figure 50. Ore-Ida Foods, Inc.

Flow Diagram for Geothermal Conversion 
The intermediate heat exchangers could either be of the shelland-tube design or the compact and versatile plate-type heat exchanger. The secondary fluid circulating to the processing tanks could either be used directly, or, as Ore-Ida representatives have considered, the fluid could pass through heat exchangers located at the processing tanks to heat the fluid in the tanks.

A11 of the secondary heat exchangers would be housed in a separate, new structure adjacent to the plant, along with the pumping and control equipment. A roughly 2,000-foot long pipeline, Figures 51 and 52, would carry fresh geothermal fluid from the well field, on company-owned property, to the heat exchanger building and waste fluid would be carried back from the building to the injection well.

Figure 53 indicates the pumping requirements for the system and also shows how control of the system could be achieved.

e. Economic Analysis

The economic analysis for the geothermal conversion of Ore-Ida Foods, Inc. assumes a ten-year depreciation life for tangible assets. Throughout the economic analys is, Ore-Ida's method of cost analysis was used. This requires 200 percent declining balance depreciation, after-tax cash flows from operations, expensing intangible costs in the year incurred, and discounting the after-tax cash flow for each year, to arrive at a present worth.

The calculation of annual savings from operations were accomplished as follows:

1) The fuel mix of natural gas and fuel oil that occurred in the year ending July 1977 was assumed to remain constant.

2) A 15-year projection of costs for natural gas to supply 100 percent space heating and 54.9 percent of process requirements was inflated at a rate of 11.2 percent annually through 1986, and 7.5 percent thereafter.

3) Costs of fuel oil were inflated at 7.5 percent annually for the 15-year projection.

4) Increased electrical power costs due to wellhead pumps and other components of the geothermal system were inflated at 8.5 percent annually through 1986 , and 7.58 percent thereafter.

5) Maintenance and repair costs were inflated at 6 percent annually, which is the projected economic inflation rate.

All of the above inflation rate projections were obtained from the Oregon Department of Energy. 


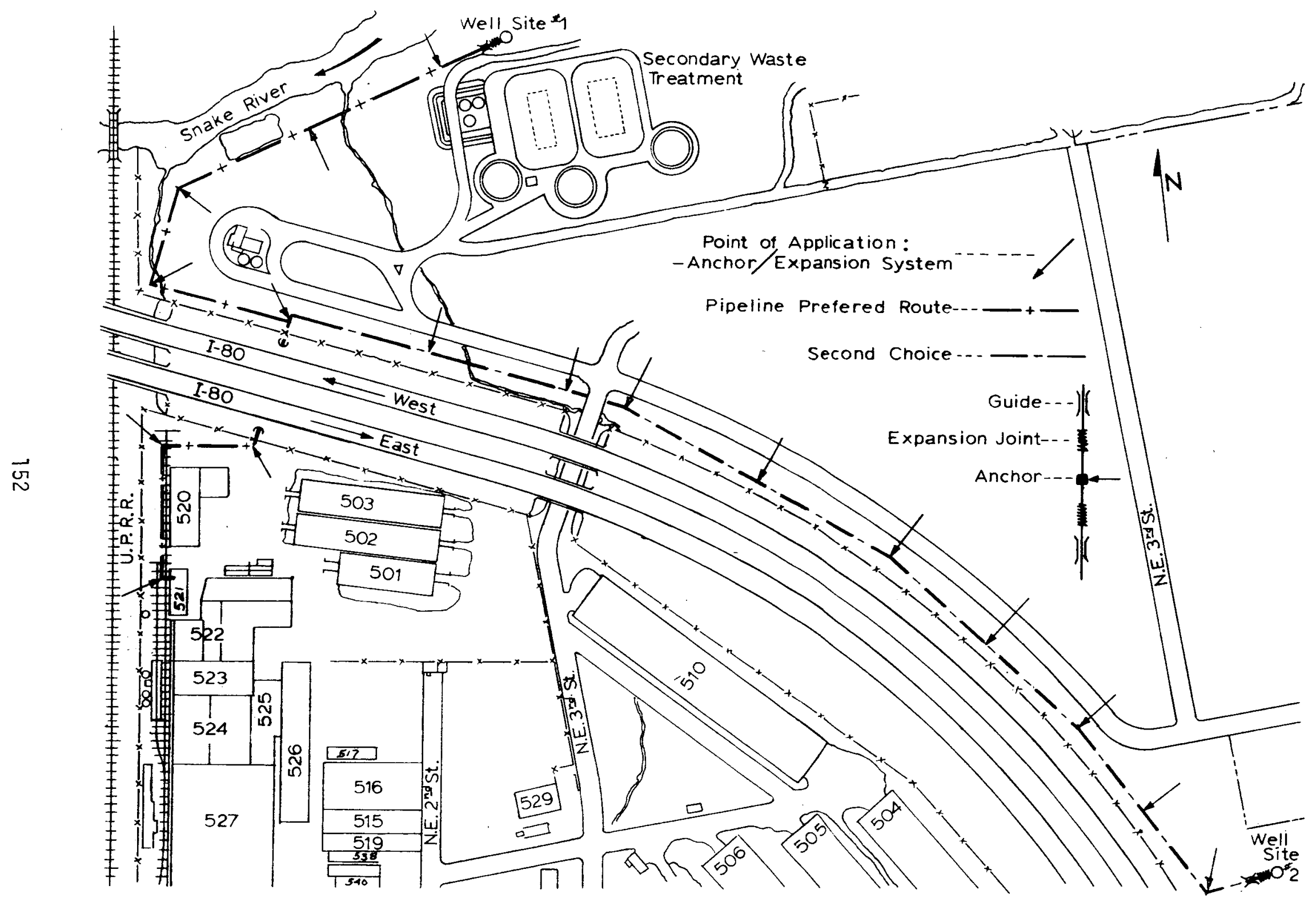

Figure 51. Ore-Ida Foods, Inc. 


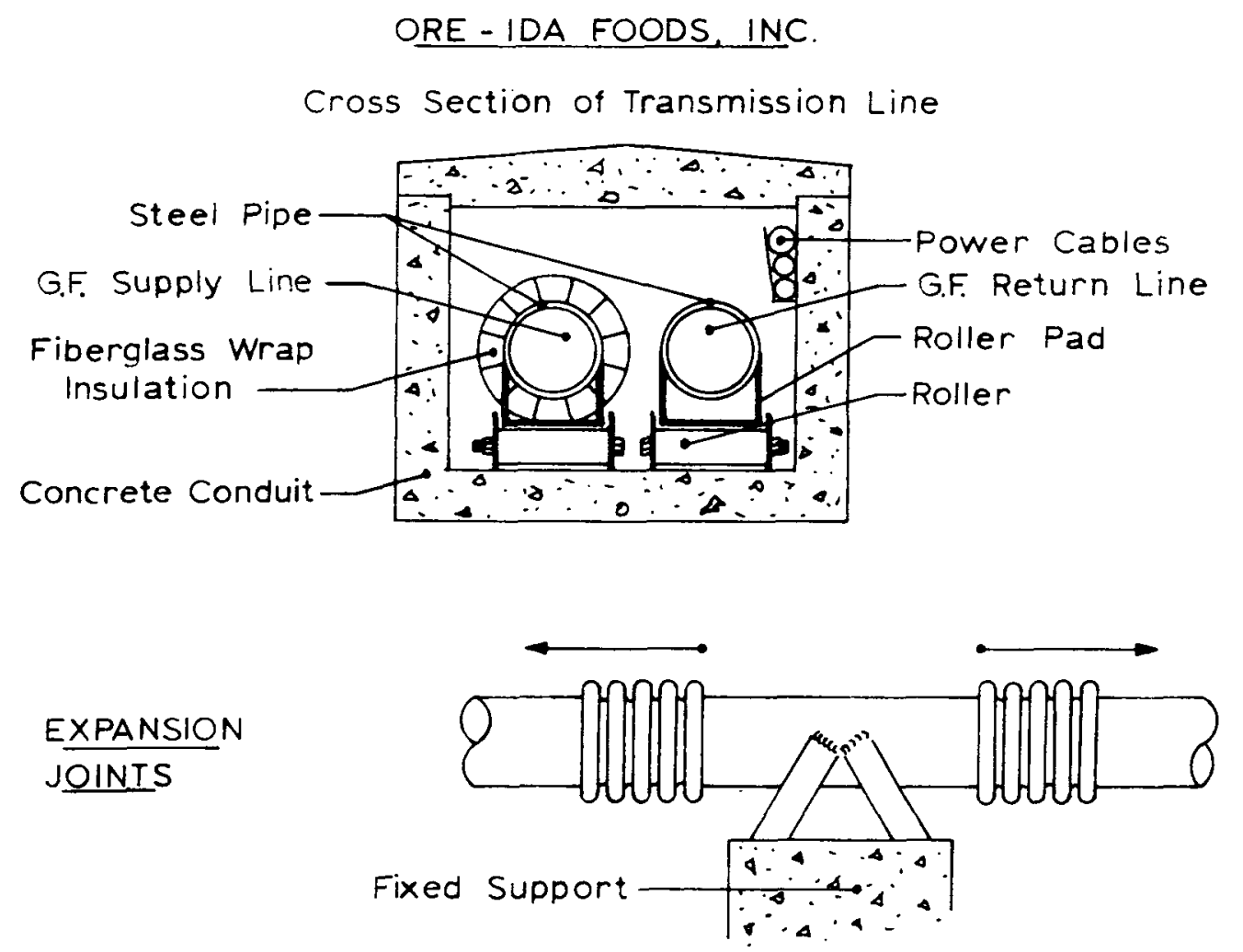

Figure 52. Cross-section of transmission line. 


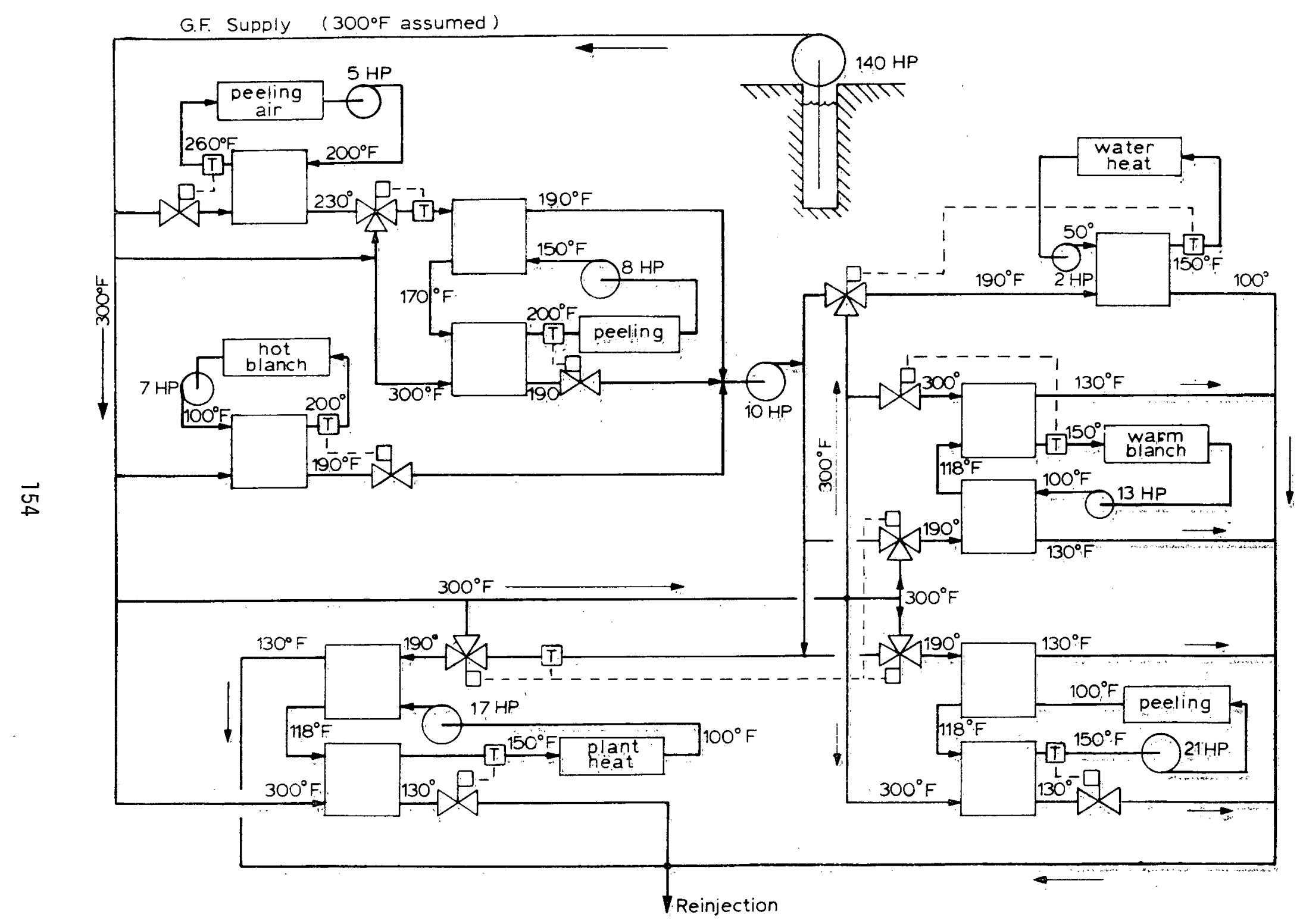

Figure 53. Ore-Ida Foods, Inc.

Control Diagram for Geothermal Conversion 
Annual costs of the geothermal system were subtracted from the projected annual costs of conventional fuels to arrive at a total annual savings before taxes.

Depletion allowances were applied to these annual savings as follows:

$$
\begin{array}{r}
1979 \text { and } 1980 \text { - } 22 \text { percent } \\
1981 \text { - } 20 \text { percent } \\
1982 \text { - } 18 \text { percent } \\
1983 \text { - } 16 \text { percent } \\
1984 \text { on }-15 \text { percent }
\end{array}
$$

This coincides with information received from Senator Packwood regarding depletion allowances for geothermal conversions.

The depletion allowance was subtracted from annual savings and the result was multiplied by 48 percent to determine the increase in federal income tax due to cost reduction. This percentage (.48) is used by Ore-Ida in calculating after-tax cash flow.

The total capital outlay of $\$ 2,848,451$ includes intangible costs after taxes of $\$ 1,321,840$, and tangible costs of $\$ 1,526,611$. On these latter costs, a 20 percent investment credit was taken at the end of year one.

A11 cash flows due to after-tax savings from operations, annual asset depletion and reduced federal taxes due to tax credits and tangible asset depreciation, were discounted at a rate of 20 percent compounded continuously, assuming uniform cash flow throughout each year to arrive at a present worth total of $\$ 4,389,908$. A second present worth calculation was done at a rate of 30 percent compounded continuously, to provide Ore-Ida with a more accurate ROI.

The cost of drilling a productive well based on total intangible estimated costs would be $\$ 2,542,000 \div 3=\$ 847,333$. The aftertax cost would be $.52(\$ 847,333)=\$ 440,613$. In drilling a nonproductive well these costs would be substantially reduced due to the fact that the well would require only surface casing and would not incur mobilization and demobilization cost. The estimated after-tax costs of a nonproducing well are estimated to be $(.52)(\$ 658,000)=\$ 342,000$. Ore-Ida requires only two producing wells and one return well and the total after-tax dollars avai1able for intangible cost at 20 percent ROI are $\$ 1,321,840+$ $\$ 1,541,457$ - $\$ 2,863,297$. Therefore, the company could afford to drill a total of eight wells to get two productive wells and use one of the nonproductive wells as a return well. In other words, with a confidence level of as low as 25 percent, they could still realize a 20 percent ROI. 


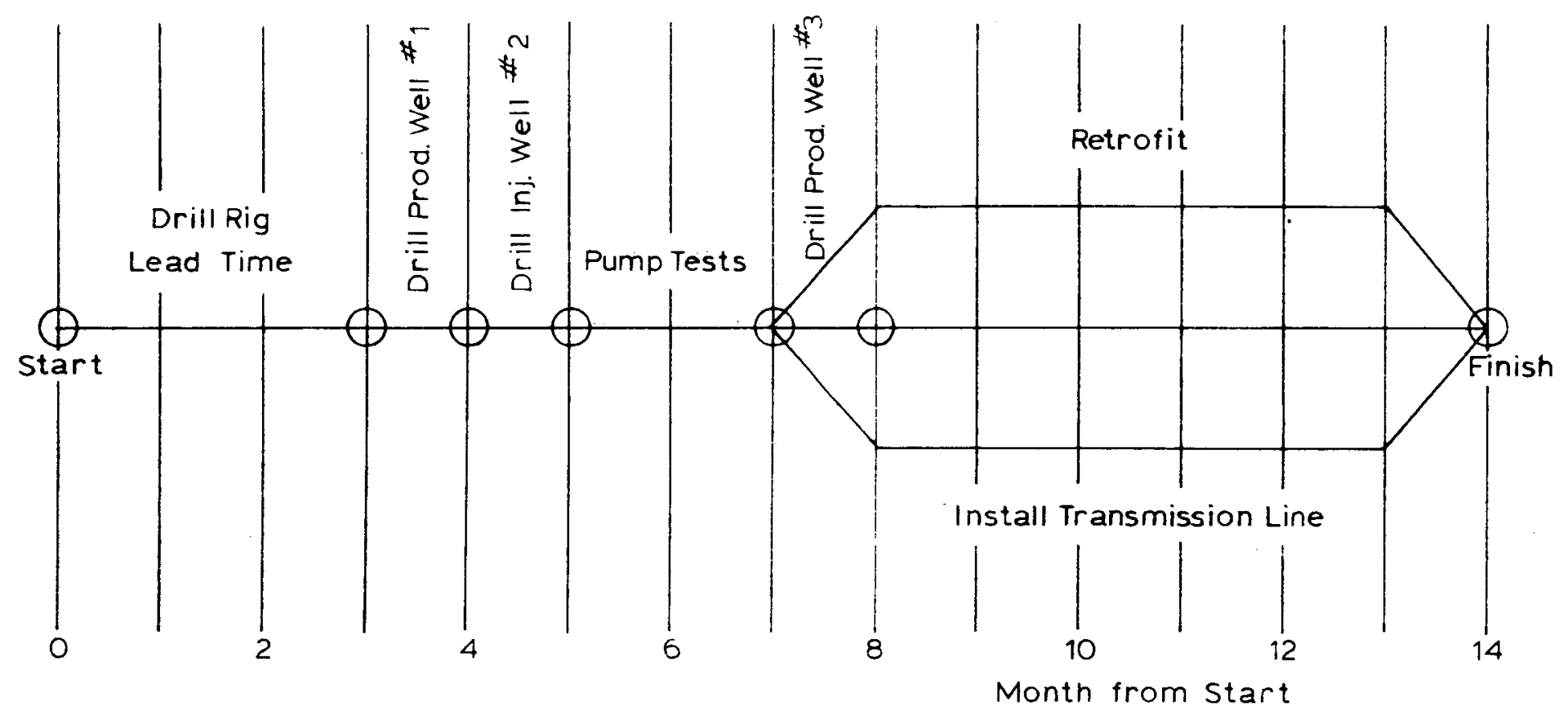

Figure 54. Ore-Ida Foods, Inc. development schedule. 
ORE-IDA FOODS, INC.

Annual Savings Recap for Geother Enal Conversion

\begin{tabular}{|c|c|c|c|c|c|c|c|c|c|}
\hline Year & $\begin{array}{l}\text { Projected } \\
\text { Costs for } \\
\text { Fuel 0il } \\
\end{array}$ & $\begin{array}{l}\text { Projected } \\
\text { Costs for } \\
\text { Natural Gas } \\
\end{array}$ & $\begin{array}{l}\text { Projected } \\
\text { Electrical } \\
\text { Power Costs } \\
\text { Geotherma } \\
\end{array}$ & $\begin{array}{l}\text { Projected } \\
\text { Maintenance } \\
\text { and Repair } \\
\text { Geothermal } \\
\end{array}$ & $\begin{array}{c}\text { Total Savings } \\
\text { Before Depletion } \\
\text { and Taxes } \\
{[A+B-(C+D)]} \\
\end{array}$ & $\begin{array}{r}\text { A } \\
\text { SInc } \\
\text { Time } \\
\end{array}$ & $\begin{array}{l}\text { etion } \\
\text { wance } \\
\text { ated \% } \\
\text { olumn E) }\end{array}$ & $\begin{array}{c}\text { Increased } \\
\text { Federal Tax } \\
\text { (E-F) .48 }\end{array}$ & $\begin{array}{c}\text { Annual } \\
\text { Savings } \\
\text { After Taxes } \\
(E-G) \\
\end{array}$ \\
\hline $\begin{array}{l}1979 \\
1980 \\
1981 \\
1982 \\
1983 \\
1984 \\
1985 \\
1986 \\
1987 \\
1988 \\
1989 \\
1990 \\
1991 \\
1992 \\
1993\end{array}$ & $\begin{array}{l}\$ 188,981 \\
203,142 \\
218,391 \\
234,770 \\
252,378 \\
271,306 \\
291,654 \\
313,528 \\
337,043 \\
362,320 \\
389,495 \\
418,707 \\
450,110 \\
483,868 \\
520,158\end{array}$ & $\begin{array}{r}682,146 \\
760,593 \\
848,061 \\
945,588 \\
1,054,331 \\
1,175,579 \\
1,310,771 \\
1,461,510 \\
1,571,123 \\
1,688,957 \\
1,815,629 \\
1,951,802 \\
2,098,187 \\
2,255,551 \\
2,424,717\end{array}$ & $\begin{array}{l}\$ 11,318 \\
12,280 \\
13,323 \\
14,456 \\
15,685 \\
17,018 \\
18,464 \\
20,034 \\
21,553 \\
23,186 \\
24,944 \\
26,835 \\
28,869 \\
31,057 \\
33,411\end{array}$ & $\begin{array}{l}\$ 15,000 \\
15,900 \\
16,854 \\
17,865 \\
18,937 \\
20,073 \\
21,278 \\
22,554 \\
23,908 \\
25,342 \\
26,863 \\
28,474 \\
30,183 \\
31,994 \\
33,914\end{array}$ & $\begin{array}{r}\$ 844,809 \\
935,555 \\
1,036,275 \\
1,148,037 \\
1,272,087 \\
1,409,794 \\
1,562,683 \\
1,732,450 \\
1,862,705 \\
2,002,749 \\
2,153,317 \\
2,315,200 \\
2,489,245 \\
2,676,368 \\
2,877,550\end{array}$ & $\begin{array}{l}22 \% \\
22 \% \\
20 \% \\
18 \% \\
16 \% \\
15 \% \\
15 \% \\
15 \% \\
15 \% \\
15 \% \\
15 \% \\
15 \% \\
15 \% \\
15 \% \\
15 \%\end{array}$ & $\begin{array}{r}\$ 185,858 \\
205,822 \\
207,255 \\
206,647 \\
203,534 \\
211,469 \\
234,402 \\
259,868 \\
279,406 \\
300,412 \\
322,998 \\
347,280 \\
373,387 \\
401,455 \\
431,633\end{array}$ & $\begin{array}{r}316,296 \\
350,272 \\
397,930 \\
451,867 \\
512,905 \\
575,196 \\
637,574 \\
706,840 \\
759,984 \\
817,122 \\
878,553 \\
944,602 \\
1,015,612 \\
1,091,958 \\
1,174,040\end{array}$ & $\begin{array}{r}528,513 \\
585,283 \\
638,345 \\
696,170 \\
759,182 \\
834,598 \\
925,108 \\
1,025,610 \\
1,102,721 \\
1,185,627 \\
1,274,764 \\
1,370,598 \\
1,473,633 \\
1,584,410 \\
1,703,510\end{array}$ \\
\hline
\end{tabular}

Electricity assumed to inflate at 8.5 percent annually through 1986 and 7.58 percent thereafter.

Maintenance and repair assumed to inflate at 6 percent annually. 
TABLE XXVI

ORE-IDA FOODS, INC.

GEOTHERMAL CONVERSION

RETURN ON INVESTMENT

Cash Flow From Operations After Taxes

$$
\begin{gathered}
(\$ 2,848,451) \\
528,513 \\
585,283 \\
638,345 \\
696,170 \\
759,182 \\
834,598 \\
925,108 \\
1,025,610 \\
1,702,721 \\
1,185,627 \\
1,274,764 \\
1,370,598 \\
1,473,633 \\
1,584,410 \\
1,703,510
\end{gathered}
$$

R.V. $\$ 163,919$

\begin{tabular}{c} 
After Tax \\
Cash Flow \\
\hline$(\$ 2,848,451)$ \\
980,390 \\
702,527 \\
732,140 \\
771,206 \\
819,211 \\
882,621 \\
963,527 \\
$1,056,345$ \\
$1,127,309$ \\
$1,205,297$ \\
$1,274,764$ \\
$1,370,598$ \\
$1,473,633$ \\
$1,584,410$ \\
$1,703,510$ \\
163,919
\end{tabular}

163,919

\section{After}

Payback

vestment

$\$$

451,877

117,244

93,795

75,036

60,029

48,023

38,419

24,588

19,670

$\begin{array}{cc} & 1.0000 \\ 1.0 & .9063 \\ 1.0 & .7421 \\ 1.0 & .6075 \\ .56 & .4974 \\ & .4072 \\ & .3334 \\ & .2730 \\ & .2235 \\ & .1830 \\ & .1498 \\ & .1227 \\ & .1004 \\ & .0822 \\ & .0673 \\ & .0551 \\ & .1353\end{array}$

3.56
Present Worth

$$
\begin{array}{r}
888,527 \\
521,345 \\
444,775 \\
383,598 \\
333,583 \\
294,266 \\
263,043 \\
236,093 \\
206,298 \\
180,553 \\
156,414 \\
137,608 \\
121,133 \\
106,, 631 \\
93,863
\end{array}
$$

22,178
$\$ 1,541,457$

$\$ 1,541,457$
D.F. 30\% Present Worth

.8639
.6400
.4741
.3513
.2602
.1928
.1428
.1058
.0784
.0581
.0430
.0319
.0236
.0175
.0130
.0498

$(\$ 2,848,451)$

846,997

449,633

347,137

270,887

213,170

170,144

137,600

111,756

88,353

69,981

54,831

43,674

34,787

$2.7,708$

22,069

8,163

$\$ 48,438$

$\mathrm{ROI}=30$ percent

After Tax Payback 3.56 years 
TABLE XXVII

ORE-IDA FOODS, INC.

Geothermal Conversion

First-Year Expenses and Investment Costs

Item

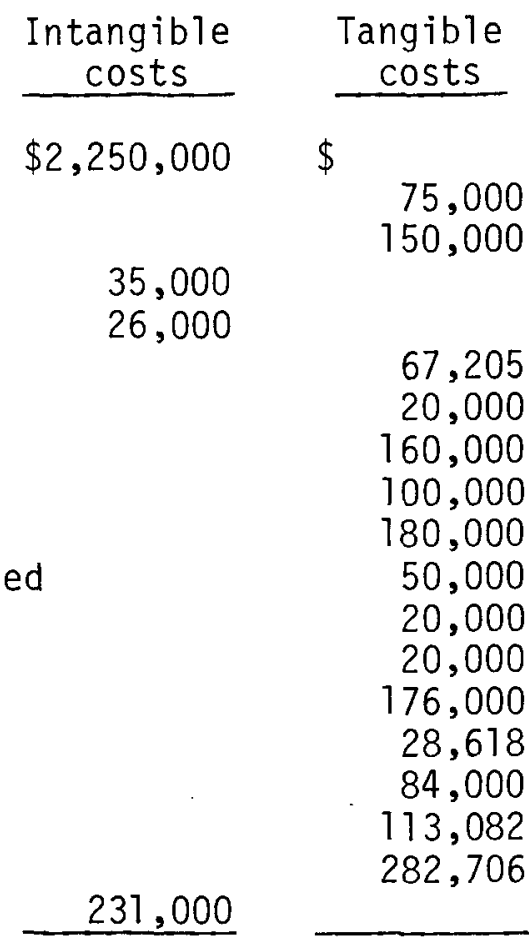

1. Drill 3 wells, $\$ 750,000$ per well

2. Wellhead equipment, $\$ 25,000$ per well

3. Well pumps, $150 \mathrm{hp}, \$ 50,000$ per well

4. Pump tests

5. Geologist $\$ 200 /$ day, 130 days

6. Power line and transformer

7. Silencer

8. Transmission 1 ine, 2,000 feet

9. Heat exchanger building

10. Heat exchangers, instailed

11. In-plant control valves and wiring, installed

12. Control unit

13. Vessels

14. In-plant piping

15. In-plant pumps, 8 pumps installed

16. Miscellaneous other pumps, installed

17. Engineering 10\% of tangible costs

18. Contingency $25 \%$ (tangible)

19. Contingency intangible $10 \%$

$\$ 2,542,000$

$\$ 1,526,611$

Tax reduction $.48 \times \$ 2,542,000$

$(1,220,160)$

Cash flow after taxes

$\$ 1,321,840$

Total cash flow after taxes

$\$ 2,848,451$ 


\title{
TABLE XXVIII
}

\author{
ORE-IDA FOODS, INC. \\ TANGIBLE ASSET DEPRECIATION
}

INVESTMENT $\$ 1,526,611$

\begin{tabular}{|c|c|c|c|}
\hline $\begin{array}{l}\text { End of } \\
\text { Year }\end{array}$ & Book Value & Depreciation & $\begin{array}{c}\text { Tax Credit } \\
\quad 48 \% \\
\end{array}$ \\
\hline $\begin{array}{r}1 \\
2 \\
3 \\
4 \\
5 \\
6 \\
7 \\
8 \\
9 \\
10\end{array}$ & $\begin{array}{r}\$ 1,221,289 \\
977,031 \\
781,625 \\
625,300 \\
500,240 \\
400,192 \\
320,154 \\
256,123 \\
204,898 \\
163,919\end{array}$ & $\begin{array}{r}\$ 305,322 \\
244,258 \\
195,406 \\
156,325 \\
125,060 \\
100,048 \\
80,039 \\
64,031 \\
51,225 \\
40,980\end{array}$ & $\begin{array}{r}\$ 451,877 \\
117,244 \\
93,795 \\
75,036 \\
60,029 \\
48,023 \\
38,419 \\
30,735 \\
24,588 \\
19,670\end{array}$ \\
\hline & . $\$ 16$ & & \\
\hline
\end{tabular}




\section{REFERENCES}

Resource Assessment

Baldwin, H. L. and Hill, D. P., 1960, Gravity Survey in Part of the Snake River Plain, Idaho--A Preliminary Report. U.S. Geological Survey, open-file report (200) R290, no. 511.

Bodvarsson, Gunnar, 1972, "Thermal Problems in the Siting of Reinjection Wells," Geothermics, v. 1, p. 63-66.

Bowen, R. G. and Blackwell, D. D., 1975, "The Cow Hollow Geothermal Anomaly, Malheur County, Oregon," Ore Bin, v. 27, no. 7, p. 109-121.

Burrows, W., 1970, "Geothermal Energy Resources for Heating and Associated Applications in Rotorua and Surrounding Areas," Geothermics, v. 2, part 2, p. 1662-1669.

Chasteen, A. J., 1975, "Geothermal Steam Condensate Reinjection," Proceedings Second United Nations Symposium on the Development and Use of Geotherma1 Resources, San Francisco, p. 1335-1336, 2466 p.

Corcoran, R. E., Doak, R. A., Porter, P. W., Pritchett, F. I., and Privrasky, N. C., 1962, "Geology of the Mitchell Butte Quadrangle, Oregon; State of Oregon Department of Geology and Mineral Industries, Geological Map Series 2.

Couch, Richard W., 1977, "Analysis of Geophysical Data Pertaining to the Vale K.G.R.A.," Final Report to the Geothermal Research Program, U.S. Geological Survey Grant 14-08-0001-G-222, 52 p.

Couch, R. W. and Baker, G., 1977, "Geophysical Investigations of the ValeOwyhee Geothermal Region, Malheur County, Oregon," Technical Report No. 2., U.S. Geological Survey, Geothermal Research Program.

Culver, G. G., Lund, J. W., and Svanevik, L. S., 1974, "Klamath Falls Hot Water Well Study," Lawrence Livermore Laboratory, University of California, UCRL-13614, 62 p.

Einarsson, Sveinn S., Vides R., Alberto, and Cuellar, Gustavo, 1975, "Disposal of Geothermal Waste Water by Reinjection," Proceedings Second United Nations Symposium on the Development and Use of Geothermal Resources, San Francisco, p. 1349-1353, 2466 p.

Hu11, D., 1975, "Geothermal Studies in the Vale Area, Malheur County, Oregon," Ore Bin, v. 37, no. 6, p. 104-106.

Illian, J. R., 1970, "Interim Report on the Ground Water in the Klamath Basin, Oregon," Oregon State Engineer, Salem, Oregon, 110 p.

Kittleman, L. R., 1973, "Guide to the Geology of the Owyhee Region of Oregon," Museum of Natural History, University of Oregon, bulletin number $21,61 \mathrm{p}$. 
Kittleman, L. R., Green, A. R., Hagood, A. R., Johnson, A. M., McCurray, J. M., Russe11, R. G., and Weeden, D. A., 1965, "Cenozoic Stratigraphy of the Owyhee Region, Southeastern Oregon," Museum of Natural History, University of Oregon, bulletin number 1, $45 \mathrm{p}$.

Kittleman, L. R., Green, A. R., Haddock, G. H., Hagood, A. R., Johnson, A. M., McCurray, J. M., Russe11, R. G., and Weeden, D. A., 1967, "Geologic Map of the Owyhee Region, Meiheur County, Oregon," Museum of Natural History, University of Oregon, bulletin number 8.

Kubota, Katsundo, and Aosaki, Kowashi, 1975, "Reinjection of Geotherma 1 Hot Water at the Otake Geothermal Field, "Proceedings Second United Nations Symposium on the Development and Use of Geothermal Resources, San Francisco, p. 1379-1383, 2466 p.

Lawrence, R. D., 1976, "Strike-S1ip Faulting Terminates the Basin and Range Province in Oregon," Geological Society of America Bulletin, v. 87, p. $846-850$.

Leonard, A. R., and Harris, A. B., 1974, "Ground Water in Selected Areas in the Klamath Basin, Oregon," Oregon State Engineer Ground Water Report No. 21, Salem, Oregon.

Long, G. L., Hoover, D. B., and Bramsoe, Erik, 1975, "Audio-Magnetotelluric Apparent Resistivity Maps, Weiser, Idaho - Vale, Oregon," U.S. Geological Survey, open-file report 75-103.

Mariner, R. H., Presser, T. S., Rapp. J. B., and Willey, L. M., 1975. "The Minor and Trace Elements, Gas and Isotope Compositions of the Principal Hot Springs of Nevada and Oregon," U.S. Geological Survey, open-file report, unnumbered, $27 \mathrm{p}$.

Mathias, Ken E., 1975, "The Mesa Geothermal Field--A Preliminary Evaluation of Five Geothermal Wells," Proceedings Second United Nations Symposium on the Development and Use of Geothermal Resources, San Francisco, p. 1747-1747, 2466 p.

Newcomb, R. C., and Hart, D. H., 1958, "Preliminary Report on the GroundWater Resources of the Klamath River Basin, Oregon," U.S. Geological Survey, open-file report, $248 \mathrm{p}$.

Newton, V. C., and R. E. Corcoran, 1963, "Petroleum Geology of the Western Snake River Basin, Oregon-Idaho," State of Oregon Department of Geology and Mineral Industries, oil and gas investigations number 1, $67 \mathrm{p}$.

Peterson, N. V., and Groh, E. A., 1967, Geothermal Potential of the Klamath Falls Area, Oregon, a Preliminary Study, "Oregon Department of Geology and Mineral Industries, Ore Bin, v. 29, no. 11, p. 209231 .

Peterson, N. V., and McIntyre, J. R., 1970, "The Reconnaissance Geology and Mineral Resources of Eastern Klamath County and Western Lake County, Oregon," Oregon Department of Geology and Mineral Industries, bulletin $66,70 \mathrm{p}$. 
Reistad, Gordon M., 1975, "Potential for Non-Electrical Applications of Geothermal Energy and Their Place in the National Economy," Proceedings Second United Nations Symposium on the Development and Use of Geothermal Resources, San Francisco, p. 2155-2164, 2466 p.

Renner, J. L., White, D. E., and Williams, D. L., 1975, "Hydrothermal Convection Systems," p. 4-47 in White, D. E., and Williams, D. L., ed., Assessment of Geothermal Resources of the United States - 1975, U.S. Geological Survey Circular 726, $155 \mathrm{p}$.

Samme1, E. A., 1976, "Hydrologic Reconnaissance of the Geothermal Area Near Klamath Falls, Oregon," U.S. Geological Survey Open File, report WRI 76-167, $129 \mathrm{p}$.

Sass, J. H., and Samme11, E. A., 1976, "Heat Flow Data and Their Relation to Observed Geothermal Phenomena Near Klamath Falls, Oregon," Journal of Geophysical Research, v. 81, no. 26, pp. 4863-4868.

Shannon, Robert J., 1975, "Geothermal Heating of Government Buildings in Rotorua," Proceedings Second United Nations Symposium on the Development and Use of Geothermal Resources, San Francisco, p. 2165-2171, $2466 \mathrm{p}$.

Sigvaldason, G. E., and Cuellar, G., 1970, "Geochemistry of the Ahuachapan Thermal Area, El Salvador, Central America," Geothermics, v. 2., part 2, p. 1392-1399.

Walker, George W., 1977, Geologic Map of Oregon East of the 121st Meridian, U.S. Geological Survey Map I-902.

Waring, Gerald A., 1965, "Thermal Springs of the United States and Other Countries of the World--A Summary," U.S. Geological Survey Prof. Paper 492, $383 \mathrm{p}$.

White, D. E., and Williams, D. L., 1975, "Assessment of Geothermal Resources of the U.S.," U.S. Geological Survey Circular 726, 155 p.

Yanagase, T., Suginohara, Y., and Yanagase, K., 1970, "The Properties of Scales and Methods to Prevent Them," Geothermics, v. 2., part 2, p. 1619-1623.

Engineering and Economic Analys is

Armstead, Christopher, 1974, Geothermal Energy, The UNESCO Press, Paris, France.

Austin, A. L., Higgins, G. H., and Howard, J. H., 1973, "The Total Flow Concept for Recovery of Energy From Geothermal Hot Brine Deposits," Lawrence Livermore Laboratory, University of California, Livermore, California.

Babits, George, 1968, Applied Thermodynamics, Allyn and Bacon, Inc., Boston, Massachusetts. 
Barr, Ronald C., 1975, "Geothermal Energy and Electrical Power Generation," Proceedings of the Second United Nations Symposium on the Development and Use of Geothermal Resources, San Francisco, California.

Boshier, John F., Economics of Non-Electric Uses of Geothermal Energy in New Zealand, CCMS Conference on Economics of Non-Electric Applications of Geotherma 1 Energy, Washington, D.C., June 21-22, 1977.

Broadlands Lucerne Co., LTD, Information Bulletin No. 1, Rotorua, New Zealand, 1977.

Dolittle, Jesse and Zerban, Alexander, 1954, Engineering Thermodynamics, International Textbook Co., Scranton, Pennsylvania.

Gordon, T. J., and Wright, T. C., The Use of Low-Quality Geothermal Heat in Grain Drying and Related Agricultural Applications, Quarterly Report, The Futures Group, Connecticut, for ERDA, January 1977, Contract E (10-1)-1628.

Green, James L., et a 1, 1977, Klamath Basin, a Potential Greenhouse Development Site, Agricultural Experiment Station, Oregon State University, Corval1 is, Oregon.

Hackett, 0. M., 1966, Ground-Water Research in the United States, U.S. Geol. Survey Cir. 527.

Keenan, Joseph and Keyes, Fredrick, 1936, Thermodynamic Properties of Steam, John Wiles and Sons, Inc., New York, New York.

King, Reno C., and Crocker, Sabin, 1973, Piping Handbook, McGraw-Hill Book Company, New York.

Linda 1, Baldur, 1974, "Geothermal Energy for Process Use;" Proceedings of the International Conference of Geothermal Energy for Industrial, Agricultural and Commercial-Residential Uses, Klamath Falls, Oregon.

Lund, John W., "Nonelectric Uses of Geothermal Energy in New Zealand," July 1976, Geo-Heat Utilizations Center Quarterly Bulletin, vol. 2., no. 1 .

McAdams, William H., 1954, Heat Transmission, McGraw-Hill Book Company, Inc., New York.

McGinnis, R. A., 1971, Beet-Sugar Technology, second edition, Beet Sugar Development Foundation, Fort Collins, Colorado.

McGuiness, C. L., 1964, Ground-Water Research of the United States, U.S. Geol. Survey Circ. 492 .

McGuiness, C. L., 1969, Scientific or Rule of Thumb Techniques of GroundWater Management--which Will Prevail?, U.S. Geol. Survey Circ. 608.

Trident Engineering Associates, Inc., April 25, 1977, Application of Solar Energy to Continuous Belt Dehydration, Final Report, Phase I, for ERDA, Division of Solar Energy, [Contract E-(40-7)-5119] 
"200' Continuous Automatic Onion Dehydrator," JuTy, 1971, Conner Packer Magazine.

UTN-CSL for State of California Department of Conservation, Apri1, 1977, Economic Study of Low Temperature Geothermal Energy in Lassen and $M$ Modoc Counties, California, (job 2775-3).

Van Anselel, Wallace B, Copley, Michael J., and Morgan, Arthur I., editors, 1973, Food Dehydration, vol. 1 and 2, The Avi Publishing Company, Inc., Westport, Conn.

Williams and Gardner, 1971, Industrial Drying, CRC Press, Cleveland, Ohio. 
$\bullet$

VI. APPENDICES

$\bullet$ 


\section{APPENDIX A \\ COMPARATIVE COSTS OF CONVENTIONAL ENERGY SUPPLIES \\ Oregon's Energy Future, First Annual Report, January 1, 1977}


In considering the price forecasts, it is important to keep in mind the distinction between current prices and prices in real terms. When prices are shown in real terms ("constant dollars"), this means that the effects of general inflation have been removed.

Prices in current dollar terms include the effects of changes in real prices and increases caused by general inflation. These are the prices consumers actually pay. In the following discussion, projections of energy prices are discussed in both real and current dollar terms depending on the context. In this report, the Oregon Department of Energy assumes an annual rate of general inflation between 5.5 and 6.0 percent.

\section{Electricity}

As a result of the shift to thermal sources of electrical operation, the real price of electricity to Oregon rate payers will increase significantly during the next two decades. Specifically, DOE projects annual increases in the average real prices of electricity sold by Oregon's private and public utilities of 2.0 and 1.2 percent, respectively, for the next 20 years. Somewhat faster rates of increase are forecasted for the first ten years. Including the effects of general inflation, this translates into a-nual rate increases of approximately 8 percent for the private utilities and 7 percent for the public utilities.

TABLE A-I

AVERAGE ELECTRICITY PRICE PROJECTIONS $(\phi / k w h)$

\begin{tabular}{|c|c|c|c|c|}
\hline \multirow[b]{2}{*}{ Year } & \multicolumn{2}{|c|}{ Residential } & \multirow[b]{2}{*}{ Commercial } & \multirow[b]{2}{*}{ Industrial } \\
\hline & $\begin{array}{l}\text { Private } \\
\text { utilities }\end{array}$ & $\begin{array}{l}\text { Public } \\
\text { utilities }\end{array}$ & & \\
\hline $\begin{array}{l}1971 \\
1976 \\
1981 \\
1986 \\
1991 \\
1996\end{array}$ & $\begin{array}{l}1.33 \\
1.92 \\
2.91 \\
4.40 \\
6.21 \\
8.78\end{array}$ & $\begin{array}{l}1.02 \\
1.41 \\
2.02 \\
2.91 \\
4.00 \\
5.53\end{array}$ & $\begin{array}{l}1.31 \\
1.82 \\
2.75 \\
4.13 \\
5.79 \\
8.17\end{array}$ & $\begin{array}{l}0.44 \\
0.74 \\
1.09 \\
1.59 \\
2.21 \\
3.12\end{array}$ \\
\hline
\end{tabular}

Petroleum Products

In contrast with electricity, petroleum products and natural gas prices are a function of decisions made at the national and international level. Consequently, future fossil fuel prices will be affected only marginally by the rate at which Oregon or the Northwest demands increase. Since fossil fuel prices are not amendable to a rigorous treatment, a more arbitrary method was used to develop a price forecast.

To forecast petroleum prices, the following assumptions are adopted: (1) the prices of crude oil from the Organization of Petroleum Exporting Countries, domestic production, and Alaska (North Slope) will be constant 
in real terms (i.e., actual prices will increase at a rate equal to the general inflation rate) for the duration of the forecast period; (2) the Pacific Northwest's dependence on Alaskan crude $0 i 1$ will increase steadily to the point that, by 1990 , most West Coast $0 i 1$ prices will come from this source; and (3) petroleum products prices will rise at the same rate as the average price of crude $0 i 1$ to West coast refineries.

Based on these assumptions, petroleum prices are projected to increase at 1.5 percent annually in real terms (more than 7 percent per year in current dollar terms) over the next 20 years. Table A-II shows projected prices for key petroleum products.

TABLE A-II

REPRESENTATIVE PETROLEUM PRICES (ф/gal)

\begin{tabular}{|cc|}
\hline Year & Heating Fuel \\
\hline 1971 & 19.2 \\
1976 & 41.3 \\
1981 & 59.5 \\
1986 & 85.9 \\
1991 & 120.8 \\
1996 & 170.0 \\
\hline
\end{tabular}

Natural Gas

Since natural gas and petroleum products compete directly in many uses, future natural gas prices are related to increases in petroleum prices. However, natural gas is currently priced below petroleum products on a heat content basis. It is assumed that natural gas will achieve price parity with petroleum products by 1986. Gas prices will then parallel petroleum prices for the rest of the forecast period. This approach yields real price increases of 5.2 percent annually through 1986 and 7.5 percent per year thereafter. Future natural gas prices are shown in Table A-III.

TABLE A-III

AVERAGE NATURAL GAS PRICES $(\phi /$ therm)

\begin{tabular}{|cccc|}
\hline Year & Residential & Commercial & Industria7 \\
\hline 1971 & 15.2 & 12.7 & 4.9 \\
1976 & 26.9 & 23.9 & 15.7 \\
1981 & 46.4 & 41.3 & 27.1 \\
1986 & 80.0 & 71.2 & 46.7 \\
1991 & 112.6 & 100.2 & 65.7 \\
1996 & 158.5 & 141.1 & 92.6 \\
\hline
\end{tabular}


0

$\theta$ 
APPENDIX B

ANNUAL EQUIVALENT COST FORMULA 
In performing economic cost analyses of geoheat systems for agribusiness as compared to conventional fuels currently in use, it became evident that price escalation of conventional fuels greatly exceeded inflation rates for well drilling, equipment purchase and installation, operating and maintenance costs. Research of available material indicated only superficial treatment of inflation rates in annual cost techniques. Efforts have been made to show how inflation lowers the value of present worth calculations or increases future costs in terms of today's dollars which would consider both the cost of capital and forecasted inflation rate based on several years of historical data. It is obvious that escalating costs could be calculated for each year over the life of an investment alternative, each cost discounted at the cost of capital to a present value, and then stated in the form of average annual cost equivalent. These calculations, however, would be extremely cumbersome particularly when dealing with long-lived wells and many components or subsystems with varying lives and repair or replacement frequencies.

In many cases, the attitude of economic analysts is simply that all alternatives are inflating at a similar rate and therefore the inflation factor can be ignored, since any decision which selects the best alternative in terms of today's dollars will also be the optimum choice in later years even though all costs may be inflated. Additionally a rate of inflation is nearly impossible to forecast. However, in this case the inflation rates of alternatives which provide energy are drastically different. Therefore, a method was necessary to provide a means of portraying these differences as accurately as possible. The following annual equivalent cost formula was developed which considers the cost of capital or rate of return together with a predictable inflation rate and selected optimum alternative. The formula can be used as a part of any conventional annual cost model.

Consider some annual cost factor in a typical annual cost-model that begins as an annual cost of $\$ 1,000$ at the end of year one and inflates at a rate of 10 percent per year in the form of a geometric progression. Annual cash flows for a five-year period would be as follows:

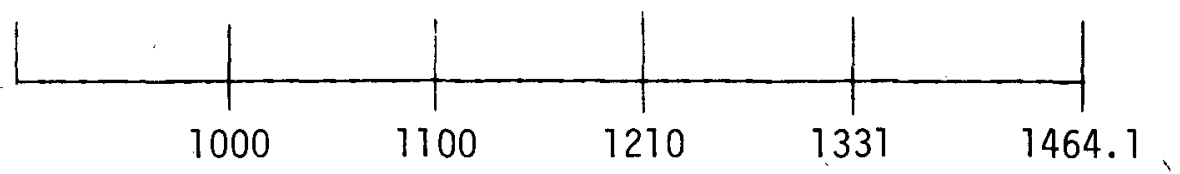

Let $\$ 1,000=a$, let the inflation rate 10 percent annually $=t$, then:

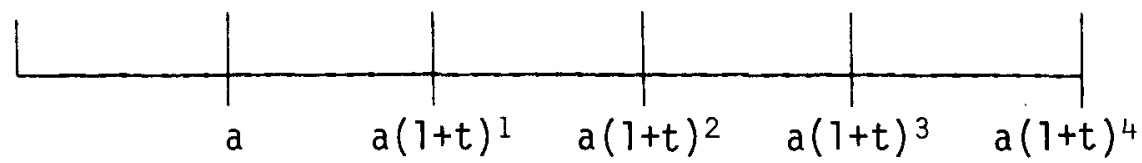


and the present worth ( $P$ ) for an assumed cost of capital of 8 percent compounded annually (i) is:

$$
P=a \frac{1}{(1+i)^{1}}+a \frac{(1+t)^{1}}{(1+i)^{2}}+a \frac{(1+t)^{2}}{(1+i)^{3}}+a \frac{(1+t)^{3}}{(1+i)^{4}}+a \frac{(1+t)^{4}}{(1+i)^{5}}
$$

where $\frac{1}{(1+i)^{n}}$ is the present worth factor Pwf. Let $n$ - number of interest periods (years in this case),

$$
\text { then } \begin{aligned}
P & =\sum_{x=1}^{n} a(1+t)^{x-1} \frac{1}{(1+i)^{x}} \\
& =\sum_{x=1}^{n} a \frac{(1+t)^{x-1}}{(1+i)^{x}}=\frac{a}{(1+i)} \sum_{x=1}^{n}\left(\frac{1+t}{1+i}\right)^{x-1}
\end{aligned}
$$

[note that: $\left.a+a r+a r^{2}+a r^{3}+\ldots+a r^{n-1}=a\left(\frac{r^{n}-1}{r-1}\right)\right]$ where $r=$ constant.

$$
\therefore \frac{a}{(1+i)} \sum_{x=1}^{n}\left(\frac{1+t}{1+i}\right) x-1=\frac{a}{(1+i)}\left[\frac{\left(\frac{1+t}{1+j}\right)^{n}-1}{\left(\frac{1+t}{1+i}\right)-1}\right]
$$

then to find the annual equivalent cost (A) considering inflation:

annual cost $=$ present $\cos t \times$ capital recovery factor

$$
\begin{aligned}
& A=P \times \operatorname{crf} \\
& A=P\left[\frac{i(1+i)^{n}}{\left.(1+i)^{n-1}\right]}\right. \\
& A=\frac{a}{(1+i)}\left[\frac{\left(\frac{1+t}{1+i}\right)^{n}-1}{\left(\frac{1+t}{1+i}\right)-1}\right] \frac{i(1+i)^{n}}{(1+i)^{n-1}}
\end{aligned}
$$

simpl ifying

$$
\begin{aligned}
& A=\frac{a}{(1+i)}\left[\left[\left(\frac{1+t}{1+i}\right)^{n}-1\right]\left[\frac{1+i}{(1+t)^{-}-(1+i)}\right]\right]\left[\frac{i(1+i)^{n}}{(1+i)^{n}-T}\right] \\
& A=\frac{a}{t-i}\left[\left(\frac{1+t}{1+i}\right)^{n}-1\right]\left[\frac{i(1+i)^{n}}{(1+i)^{n}-1}\right]
\end{aligned}
$$


Adopting the notation used by the American Telephone and Telegraph Company in their text Engineering Economy, second edition, 1963, for purposes of standardization, as follows:

To find:

Future value

Present value

Fugure value

Amount of Annuity A

Present value

Amount of Annuity $A$
Given:

Present value

Future value

Annuity of Amount A

Future value

Annuity of Amount $A$

Present value
Notation:

$$
\begin{aligned}
& (f / p)_{n}^{i} \\
& (p / f)_{n}^{i} \\
& (f / a)_{n}^{i} \\
& (a / f)_{n}^{i} \\
& (p / a)_{n}^{i} \\
& (a / p)_{n}^{i}
\end{aligned}
$$

where $i$ is the interest rate per interest period and $n$ is the number of interest periods,

the formula becomes:

$$
\begin{aligned}
& A=\frac{a}{t-i}\left[(f / P)_{n}^{t}(P / f)_{n}^{i}-1\right](a / P)_{n}^{i} \text { and can be easily calculated } \\
& \text { using compound interest tables. }
\end{aligned}
$$

Using the initial values in this example:

$$
A=\frac{1000}{.10-.08}[(1.611)(.6806)-1] \quad(.2505)=\$ 1,207.99
$$

the average annual equivalent cost.

It should be noted when $i=t$ the expression becomes $\frac{0}{0} \rightarrow$ undefined.

$\therefore \lim _{i \rightarrow t}\left(\frac{1}{1+i}\right)\left[\frac{\left.\left(\frac{1+t}{1+i}\right)^{n}-1\right]}{\left(\frac{1+t}{1+i}\right)-1}\right]$
$=\lim _{i \rightarrow t}\left(\frac{1}{1+i}\right)\left[\frac{\left[\left(\frac{1+t}{1+i}\right)-1\right]\left[\left(\frac{1+t}{1+i}\right)^{n-1}+\left(\frac{1+t}{1+j}\right)^{n-1}+\cdots+1\right]}{\left(\frac{1+t}{1+1}\right)-1}\right]$ 


$$
\begin{aligned}
& =\lim _{i \rightarrow t}\left(\frac{1}{1+i}\right)\left[\left(\frac{1+t}{1+i}\right)^{n-1}+\left(\frac{1+t}{1+i}\right)^{n-2}+\ldots+1\right] \\
& =\lim _{i \rightarrow t}\left(\frac{1}{1+i}\right)\left[\left(\frac{1+i}{1+i}\right)^{n-1}+\left(\frac{1+i}{1+i}\right)^{n-2}+\ldots+1\right]
\end{aligned}
$$


0

\section{.}




\section{APPENDIX C \\ POTENTIAL FOR GREENHOUSE DEVELOPMENT \\ IN THE KLAMATH BASIN BY SUBAREA}


The potential for the greenhouses to be used for specific crops will be stated. However, alternate crops must be considered for uses when competition and/or marketing factors make a specific crop unprofitable. Tree seedlings appear to be the most attractive crop at this time. The following section will describe their potential in detail.

Klamath Falls/North Altamont/Pelican City Subarea

This subarea is the most heavily populated of the six. A 15-acre greenhouse complex could be located in the City Industrial Park adjacent and west of the OIT campus. Plentiful supplies of water at temperatures of $194^{\circ} \mathrm{F}$ are known to be producing from 1,800 feet at OIT and the hospital wells. The area between OIT and Wocus has sufficient room for the industry but is untested for geothermal resources. Cold groundwater supplies are not in good supply but a city water main could be extended from Klamath Falls to the site.

The 01d Fort Road area appears to have potential for both hot and cold water but 15 -acre site locations are not available.

The Lake Ewauna to Summers Lane area is heavily populated and few 15acre sites would be available. Water temperatures are not as high as in the OIT area, nor would the quantities be as great.

Any location in this subarea would be close to a plentiful labor force, good transportation facilities and a multiple crop market. Crop types could be foliage plants, potted flowers, cut flowers, tree seedlings, vegetables or a combination of any or all crops.

\section{South Altamont/Miller Hill Subarea}

Many areas have available land for a 15-acre site in this subarea. Water temperatures of $140^{\circ} \mathrm{F}$ would be sufficient for greenhouses but there may be insufficient quantities of both hot and cold water for greenhouse purposes.

Cold water is highly mineralized in certain portions of this area and will need to be carefully evaluated before being used for irrigation of valuable crops.

The most promising location could be east of Midland in the Miller Hill area ranging north-northwesterly to the Klamath River. Shallow coldwater wells have better water quality than those deeper than 260 feet. Chemical analyses would be recommended for both hot- and cold-water supplies and pumping tests should be made to establish quantities.

Any location in this subarea would be close to a labor force and transportation. Crop types could be the same as for the Klamath Falls/ North Altamont subarea. 


\section{Klamath Hills/Spring Lake Valley Subarea}

A we11-known geothermal zone is in this area at shallow depths and with plentiful hot-water supplies. The known area ranges in a narrow band along the southwest border of the Klamath Hills. Several sites are available for 15 or more acres of greenhouses each. One such enterprise is planning to begin construction during mid to late summer, 1977. This will be on the Jack Liskey Ranch and their primary crop will be tree seedlings. Good quality cold water for irrigation may be difficult to obtain on the sites and it may be necessary to pipe it in from another area.

The labor force to care for the greenhouses would be several miles from the site. Access to highway transportation is good.

Crop types could be the same as for the Klamath Falls/North Altamont subarea.

Olene Gap/Poe Valley Subarea

Several hot springs emerge into Lost River at 0lene Gap. However, locations of building sites which are assessable are not available adjacent to the spring area. Ranging south-southwesterly from the Gap are plentiful greenhouse sites for 15-acre complexes.

This area which ranges as far south as Nuss Lake has high well gradients, and, although no deep wells have been drilled, it appears that resources would be available. Some cold-water wells south of the Gap are good producing wells of good quality but some are high in sodium. Chemical content should be evaluated before being used for irrigation.

Only two small areas along the North Poe Valley Road give evidence of geothermal resources. Each area is large enough for a 15-acre site.

All potential locations within this subarea are distant from labor forces and transportation. Tree seedling crops could be grown with a small labor force and easily transported to the planting sites.

\section{Merrill/Mal in Subarea}

The area along the west flank of Stukel Mountain gives indications that sufficient geothermal resources are available at less than $1 \mathrm{~km}$ of depth. The same is true of a larger area northeasterly of Merrill. Each has sufficient area for one or more 15-acre greenhouse industries. Three smaller and more isolated areas west and south of Merrill show geothermal potential but are very isolated with limited area and access. Cold-water supplies appear adequate.

Greenhouses could be located in any of the areas mentioned. Potential labor forces appear inadequate. Growing tree seedlings would be the better crop, but foliage plants could also be grown. 


\section{Keno/Klamath River Subarea}

The only evidence of geothermal resources in this subarea is within a populated hilly subdivision and on the flood plains of the Klamath River. other subareas indicate better potentials for geothermal resources and with better access to labor forces and transportation facilities.

\section{Langell Valley Subarea}

The best potential greenhouse site for this subarea would be at the Turner Hot Spring location. A good (40 gpm) hot-water flow could be successfully utilized at the spring and adjacent areas show good thermal gradients. Plentiful supplies of cold water of good quality are available.

Langell Valley is distant from any labor force and transportation lines. Tree seedlings would probably be the best crop for the area.

Sprague River Subarea

This subarea has no proven potential for geothermal resources and is distant from a labor force and transportation lines. Other subareas show better potential for greenhouse industries. 
APPENDIX D

ORGANIZATIONS CONTACTED

The following organizations cooperated in providing data and background information during the course of this study. Their assistance is gratefully acknowledged. 
Food Processors

Amalgamated Sugar Company

Nyssa, Oregon

Fred Franz

Nelson C. Hiner

American Fine Foods, Inc.

Payette, Idaho

Ron Schoen

Eastern Oregon Farming Company

Irrigon, Oregon

Robert Lamb

Newha11 Land and Farming Company

Dixon, California

Ore-Ida Foods, Inc.

Ontario, Oregon

Bob Pederson

Robert W. Rolf

James $W$. Linford

Jack Collins

Western Polymer Corporation

Tulelake, California

Jim Aslett

Maurene Eh1ers

Equipment Manufacturers

Bert Farnes Company

Portland, Oregon

Larry Paulus

Brod and McClung

Portland, Oregon

Chuck Ingham

E. S. Constant Company

Portland, Oregon

Ron Hoover

Interstate Pump Company

Klamath Falls, Oregon

Lee Campbe1]
Equipment Manufacturers (cont.)

Johns-Mansville

San Francisco, California Howard Harvey

Johnson Controls

Portland, Oregon

John Green

Proctor and Schwartz

San Jose, California

Fred L. Wietersen

Roland Hardle Construction Company

Bend, Oregon

Sage Cable Company

Sage Pipeline, Inc.

Gold Hill, Oregon

Walter Brotherton

Others

Broadlands Lucerne Company, Ltd.

Rotorua, New Zealand

D. N. Pirrit

Bill Burrows

Rotorua, New Zealand

FJARHITUN, Ltd.

Reykjavik, Iceland

Karl Omar Jonsson

Ingolfur Adalsteinsson

National Energy Authority

Reykjavik, Iceland

Stefan Sigurmundsson

Gylfi Petursson

Oregon Department of Energy

Salem, Oregon

Walt Pol lock

Oregon State Experiment Station

Klamath Falls, Oregon

George Carter

Lonnie Allison 
Others (cont.)

Reykjavik Municipal District Heating Service

Reykjavik, Iceland Johannes Zoega

Gunnar Kristinsson

University of California Experiment Station

Tulelake, California

Paul Puri

Ken Baghott

Comprehensive Planning Program

Vale, Oregon

Bill Clark

Klamath County Economic Development Association

Klamath Falls, Oregon

Tom Lund 
DISTRIBUTION RECORD FOR IDO/1621-1

Internal Distribution

1 - Chicago Patent Group - DOE 9800 South Cass

Argonne, IL 60439

1 - R. L. Blackledge Idaho Operations Office - DOE Idaho Falls, ID 83401

1 - H. P. Pearson Information Management - EG\&G

6 - INEL Technical Library

10 - Special Internal

External Distribution

442 - UC-66g--GE: Direct Applications of Heat from Geothermal Resources

Total Copies Printed: 561 